\title{
TERUGBLIK
}

\section{op toekomstuerkenningen}

\section{WRR}

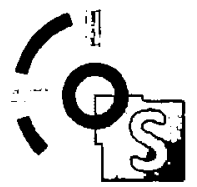

$\begin{array}{lll}N R L & L \\ Y & \end{array}$

\section{WERKDOCUMENT 1}

STUURGROEP TOEKOMSTONDERZOEK EN STRATEGISCH OMGEVINGSBELEID

NRO

Den Haag, oktober 2000 
Initiatiefnemers van het project zijn de NRO, RMNO en de NRLO

Finanders: cos en de WRR

De stuurgroep t\&o bestaat uit: vooritter Prof. dr. J. Bouma (raadslld WRR),

Dr. H.C. van Latesteyn (WRR), Dr. A.N. van der Zande (Alterra),

Prof. Dr. P. Rademakers, Prof. Dr. R.J. In t Veld, Drs. J.J. Modder (NRO, NIROV), Dr. Ir. A.P. Verkaik (NRLO), Drs. Ing. A.H.J. Moerkamp (VROM), C. Lever (vervanger Moerkamp), Drs. H. Schartman (V\&W), Dhr. Rijnbout (HMD).

Projectsecretariaat:

drs. J. Saris (directeur De Stad B.v.) en drs. T. Metze (De Stad B.v.)

Omslagontwerp: Studio Daniëls, 's-Gravenhage

Drukwerk: Enroprint, Rijswijk 


\section{VOORWOORD}

Voor u ligt het eerste werkdocument van de Stuurgroep Toekomstonderzoek en strategisch Omgevingsbeleid (T\&O). Hierin worden de resultaten van de eerste fase van het project T\&O gepresenteerd. Het bevat een ex-postanalyse van zes recente toekomstverkenningen en een weergave van de conferentie op 24 maart 2000. De stuurgroep acht een publicatie van deze analyse en de reacties daarop reeds nu van belang, omdat deze relevante leerervaringen bevat en het inspiratie biedt voor meer reacties. Het werkdocument is een eerste belangrijke bouwsteen voor het project, dat rond juni $2001 \mathrm{zal}$ worden afgerond.

Een jaar geleden is door de instelling van de stuurgroep T\&o gevolg gegeven aan een van de belangrijkste aanbevelingen van de commissie Infrastructuur Toekomstonderzoek Landelijk en Stedelijk Gebied (in de wandeling de commissie van den Ban). Deze aanbeveling luidde: "Voor het verdergaand optimaliseren van de interactie tussen beleid en onderzoek achten wij het van veel belang dat de door ons gestarte open dialoog tussen beide subsystemen in de toekomst wordt voortgezet. Bij deze dialoog dient het bedrijfsleven en de politiek nadrukkelijker te worden betrokken dan in onze werkperiode het geval was".

Nadat de opdrachtgevers van de commissie, de NRLO, de NRO en de RMNO, deze aanbeveling hadden overgenomen, heeft ook de WRR zich bereid getoond aan deze activiteit deel te nemen. Zowel de WRR als de sectorraden die vertegenwoordigd zijn in de cos, hebben zich financieel gecommitteerd en een stuurgroep ingesteld. Deze stuurgroep bestaat uit vertegenwoordigers van toekomstonderzoek en omgevingsbeleid. Zij streven ernaar in het slotdocument een aantal succesvoorwaarden te formuleren voor de inzet van toekomstonderzoek in de arena van het omgevingsbeleid. Om dit te kunnen doen, heeft de stuurgroep een onderzoeks- en een interactiespoor uitgezet, waarbij het onderzoek de inhoudelijke input levert voor de interactie met relevante actoren. In het werkdocument vindt $\mathbf{u}$ de twee sporen terug, respectievelijk in het eerste en tweede deel.

In de tweede fase van het project zullen een aantal lopende verkenningen en besluitvormingsprocessen onder de loep worden genomen. Ook is een werkgroep methodologie in het leven geroepen die een theoretische verdieping zal geven aan noties over toekomstonderzoek en omgevingsbeleid.

Deze activiteiten samen zijn de bouwstenen voor de uiteindelijke rapportering van het T\&O project, die als resultante wordt gezien van een gemeenschappelijk leerproces van de stuurgroepleden T\&o enerzijds, en de vele betrokkenen bij onderzoek en beleid anderzijds.

Namens de stuurgroep,

Prof. Dr. J. Bouma

Oktober 2000 


\section{INHOUDSOPGAVE}

Voorwoord 3

Algemene inleiding 9

Deel I Het onderzoeksspoor - terugblik op toekomstverkenningen

$1 \quad$ Inleiding 13

2 Het conceptueel kader $\quad 15$

$\begin{array}{lll}2.1 & \text { Inleiding } & 15\end{array}$

2.2 Het object van studie: het proces van toekomst$\begin{array}{ll}\text { verkenning } & 16\end{array}$

2.3 Verkenningen reconstrueren; over interacties, actoren, $\begin{array}{ll}\text { percepties en producten } & 18\end{array}$

2.4 Ideaaltypen om toekomstverkenningen te beoordelen 20

2.5 Samenvatting 25

3 De casus 27

3.1 Brabant $2050 \quad 27$

$\begin{array}{lll}3.1 .1 & \text { Inleiding } & 27\end{array}$

3.1.2 De perceptie van de opdrachtgever 29

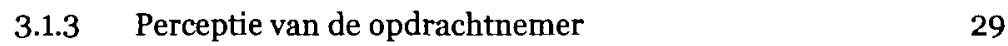

3.1.4 De organisatie van het onderzoekstraject 30

3.1.5 De organisatie van de overdracht 31

3.1.6 Benutting van de resultaten van de toekomstverkenning 32

3.1.7 Conclusie 33

3.2 Scenario's voor landbouw en ruimtegebruik in NoordBrabant $\quad 34$

3.2.1 Inleiding 34

3.2.2 De aard en wijze van het opdrachtgeverschap 35

3.2.3 Perceptie van de opdrachtnemer 35

3.2.4 De organisatie van het onderzoekstraject 36

$\begin{array}{ll}\text { 3.2.5 De organisatie van de overdracht } & 37\end{array}$

3.2.6 Benutting van de resultaten van de toekomstverkenning 38

$\begin{array}{lll}3.2 .7 & \text { Conclusie } & 39\end{array}$

$\begin{array}{lll}3.3 & \text { Natuurverkenning } 1997 & 40\end{array}$

$\begin{array}{lll}3.3 .1 & \text { Inleiding } & 40\end{array}$

3.3.2 De perceptie van de opdrachtgever 42

3.3.3 Perceptie van de opdrachtnemer 43

3.3.4 De organisatie van het onderzoekstraject 44

3.3.5 De organisatie van de overdracht 45

3.3.6 Benutting van de resultaten van de toekomstverkenning 45 
3.3.7 Conclusies 46

$3.4 \quad$ Nederland $2030 \quad 47$

$\begin{array}{lll}3.4 .1 & \text { Inleiding } & 47\end{array}$

3.4.2 De perceptie van de opdrachtgever 50

3.4.3 Perceptie van de opdrachtnemer 51

3.4.4 De organisatie van het onderzoekstraject 51

3.4.5 De organisatie van de overdracht 53

3.4.6 Benutting van de resultaten van de toekomstverkenning 53

3.4.7 Conclusie 54

$3.5 \quad$ Woonverkenningen MMxXX 55

3.5.1 Inleiding 55

3.5.2 De perceptie van de opdrachtgever 56

3.5.3 Perceptie van de opdrachtnemer 58

3.5.4 De organisatie van het onderzoekstraject 58

$\begin{array}{lll}\text { 3.5.5 De organisatie van de overdracht } & 60\end{array}$

3.5.6 Benutting van de resultaten van de toekomstverkenning 60

$\begin{array}{lll}3.5 .7 & \text { Conclusie } & 61\end{array}$

3.6 Wuesta: verplaatsen in de toekomst 62

$\begin{array}{lll}3.6 .1 & \text { Inleiding } & 62\end{array}$

3.6.2 De perceptie van de opdrachtgever 64

3.6.3 Perceptie van de opdrachtnemer 64

$\begin{array}{lll}\text { 3.6.4 De organisatie van het onderzoekstraject } & 65\end{array}$

$\begin{array}{lll}\text { 3.6.5 De organisatie van de overdracht } & 68\end{array}$

3.6.6 Benutting van de resultaten van de toekomstverkenning 68

$\begin{array}{lll}3.6 .7 & \text { Conclusie } & 69\end{array}$

4 Vergelijkende analyse 77

$\begin{array}{lll}4.1 & \text { Inleiding } & 77\end{array}$

$\begin{array}{lll}4.2 & \text { Het verkennen als populaire activiteit } & 77\end{array}$

4.3 De inhoud van hedendaagse toekomstverkenningen:

4.4 Het opdrachtgeverschap $\quad 80$

$\begin{array}{lll}4.5 & \text { Het opdrachtnemerschap } & 82\end{array}$

4.6 Het traject van toekomstverkenning 83

$\begin{array}{lll}4.7 & \text { De organisatie van de overdracht } & 83\end{array}$

4.8 Benutting van de resultaten van de toekomstverkenning 84

$\begin{array}{ll}4.9 & 85\end{array}$

$\begin{array}{lll}5 & \text { Epiloog } & 87\end{array}$ 
Deel II Het interactiespoor -Verslag conferentie Terugblik op toekomstverkenningen'

6 Daginleidingen 93

6.1 Inleiding door prof.dr.ir J. Bouma, voorzitter van de stuurgroep

6.2 Prof.dr.ing. G.R. Teisman geeft een inleiding bij het discussiestuk 'Terugblik op toekomstverkenningen' 94

6.2.1 Inleiding 94

6.2.2 Afbakening van het onderzoeksobject 95

6.2.3 Conclusies van de terugblik 98

$\begin{array}{lll}6.2 .4 & \text { Discussiepunten } & 100\end{array}$

$7 \quad$ Werkgroepdiscussies 103

7.1 Brabant 2050 en Scenario's voor landbouw en

$\begin{array}{lll}7.1 .1 & \text { Opening } & 103\end{array}$

$\begin{array}{lll}\text { 7.1.2 Casus 1: Manifest } 2050 & 103\end{array}$

7.1.3 Casus 2: Scenario's voor landbouw en ruimtegebruik in Noord-Brabant 104

$\begin{array}{lll}7.1 .4 & \text { Sterke en zwakke punten } & 104\end{array}$

$\begin{array}{lll}7.2 & \text { Natuurverkenningen '97 } & 108\end{array}$

$\begin{array}{ll}7.2 .1 & \text { Opening } \\ 7.2 .2 & 108\end{array}$

$\begin{array}{lll}7.2 .2 & \text { De Natuurverkenning '97 } & 108\end{array}$

7.2.3 De stellingen en reacties 111

7.2.4 Reacties op stelling $1 \quad 111$

7.2.5 Stelling 3: de overdraagbaarheid van kennis uit de

$\begin{array}{lll}\text { 7.2.6 Tot slot, de leerpunten } & 113\end{array}$

$\begin{array}{lll}7.3 & \text { Werkgroep Nederland } 2030 & 114\end{array}$

$\begin{array}{ll}\text { 7.3.1 Opening en stellingen } & 115\end{array}$

7.3.2 Stelling 1: vervlechten en ontvlechten 116

7.3.3 Stelling 3: het vergetende ministerie 117

$\begin{array}{ll}7.4 \text { Werkgroep Woonverkenningen } & 119\end{array}$

$\begin{array}{ll}7.4 .1 & \text { Opening en stellingen } \\ 7.4 .2\end{array}$

7.4.2 Stelling 1: vervlechting en ontvlechting 120

$\begin{array}{lll}7.5 & \text { Werkgroep Questa } & 126\end{array}$

$\begin{array}{ll}7.5 .1 & \text { Opening en stellingen } \\ 7.5 .2 & 126\end{array}$

7.5.2 Stelling 1: vervlechten en ontvlechten 126

7.5.3 Stelling 2: overdracht aan andere beleidsonderdelen 128

7.5.4 Stelling 3: moeizame vervlechting in het niemandsland 129 
$8 \quad$ Plenaire discussie 133

9 Nabeschouwing van de ex-postanalyse en de conferentie $\quad 145$

$\begin{array}{lll}9.1 & \text { Inleiding } & 145\end{array}$

9.2 Reacties en leerpunten en -ervaringen per conclusie uit de 'Terugblik op toekomstverkenningen' 145

9.3 Meer algemene opmerkingen over de 'Terugblik op toekomstverkenningen' 152

$\begin{array}{ll}\text { Bijlagen } & 155\end{array}$

A Interviews 157

$\begin{array}{ll}\text { B Samenvatting } & 159\end{array}$

C Initiatiefnemers en financiers 169

D 'Terugblik op toekomstverkenningen' 171

E Een ingeblikt interview met mw. M. de Boer,
oud-minister van VRoM 


\section{ALGEMENE INLEIDING}

Door de commissie van den Ban is geconstateerd dat de interactie tussen de toekomstverkenningen en het strategisch beleid in het algemeen gebrekkig is. Het gevolg kan zijn dat toekomstverkenningen onvoldoende georiënteerd zijn op strategische beleidsdilemma's en mede daardoor onvoldoende worden benut. Aan de hand van het rapport bleek het geen eenvoudige opgave om eenstemmigheid te bereiken over de vraag hoe een juiste interactie er uit zou moeten zien, en de kloof tussen de twee arena's kan worden overbrugd.

De eerste fase van het project Toekomstonderzoek en strategisch Omgevingsbeleid (T\&O) omvat een probleemanalyse van deze veronderstelde kloof. Deze ex-postanalyse is, op verzoek van de stuurgroep, uitgevoerd door prof.dr.ir. G.R. Teisman en het projectsecretariaat. In het eerste deel van het document vindt $u$ deze ex-postanalyse. Hierin ligt nadrukkelijk de focus op de verkenningentrajecten en op de interactie die is aangegaan tussen de opdrachtgevers en opdrachtnemers. Het onderzoek dient om een scherper zicht te krijgen op het object van onderzoek van het project T\&o. Prof. Teisman heeft in de analyse een conceptueel kader ontwikkeld om de interactie tussen de opdrachtgevers en opdrachtnemers van zes recente verkenningenprocessen te reconstrueren. Ook is in het onderzoek gekeken naar de organisatie van ieder verkenningentraject, en naar de overdrachtsregelingen om de opgedane kennis in het beleidsproces te gebruiken. De reconstructie heeft plaatsgevonden op basis van documenten en interviews.

De zes verkenningen zijn zeer verschillend van aard en hebben uiteenlopende benaderingen, van zeer klassiek tot zeer experimenteel. Dit heeft als nadeel dat zij moeilijk inhoudelijk vergelijkbaar zijn waardoor generaliseerbare conclusies over de inhoud van de verkenningen in dit stadium nog nauwelijks te trekken zijn. Uit de ex-postanalyse komt wel duidelijk naar voren dat de metafoor van de kloof losgelaten dient te worden, en dat er eerder sprake is van een bepaalde mate van vervlechting en ontvlechting van onderzoek en beleid. Die mate van vervlechting en ontvlechting is op bepaalde momenten in het proces verschillend, en kan ook op meer niveaus benaderd worden, bijvoorbeeld op actor-, kennis-, of institutioneel niveau.

In het tweede deel van dit werkdocument vindt $u$ in de reacties op de ex-postanalyse van deelnemers aan een door de stuurgroep belegde conferentie op 24 maart 2000. Daaruit blijkt dat over het algemeen de terminologie van vervlechting en ontvlechting zeer hanteerbaar werd gevonden. Bovendien wordt een scheiding van 'willen', 'weten' en 'kunnen' ter discussie gesteld. Meerdere malen wordt door deelnemers geconstateerd dat deze drie begrippen wel onderscheiden maar niet gescheiden kunnen worden. Ook blijkt dat het noodzakelijk zal zijn in het vervolg van het project T\&O niet alleen naar de procesmatige kant 
te kijken, maar nog meer naar de inhoud van de methodologie van de verkenningen. Zoals uit het voorwoord al bleek, geeft de stuurgroep hier gehoor aan, onder andere door het instellen van een werkgroep methodologie.

Tot slot is een nabeschouwing opgenomen. Daarin zijn de belangrijkste constateringen uit het onderzoek van prof. Teisman en het secretariaat en de conferentie aan elkaar gekoppeld. Hierdoor ontstaat een duidelijk en beknopt overzicht van deze eerste fase van het project T\&o. 


\section{DEEL I}

HET ONDERZOEKSSPOOR

TERUGBLIK OP TOEKOMSTVERKENNINGEN 


\section{INLEIDING}

Op het brede terrein van het omgevingsbeleid hebben verschillende overheden de afgelopen jaren toekomstverkenningen laten verrichten. Zoals bij elke onderzoeksgolf is ook in deze nieuwe 'generatie' verkenningen getracht recht te doen aan veranderde maatschappelijke omstandigheden en nieuwe methodologische inzichten. Dat gesproken kan worden over een nieuwe generatie toekomstverkenningen blijkt wel uit de terminologie: vele van deze onderzoeken noemen zichzelf toekomstverkenning en geven daarmee uiting aan een onderscheid met het verleden. Zodoende is een schat aan nieuwe ervaringen beschikbaar gekomen met recent ontwikkelde en nog weinig gebruikte methodieken en processen. De Stuurgroep, die is ingesteld om zich te verdiepen in de relatie tussen toekomstonderzoek en strategisch omgevingsbeleid, heeft de beschikbaarheid van deze schat aan ervaringen aangegrepen om na te gaan hoe die zich in de recente verkenningen de trajecten van onderzoek en van strategische beleidsontwikkeling tot elkaar verhouden.

Het voorliggende onderzoek is een eerste stap in de uitvoering van het plan van aanpak van de Stuurgroep t\&o. In het plan van aanpak wordt erop gewezen dat zich de afgelopen jaren een aantal nieuwe ontwikkelingen hebben voorgedaan die zich onderscheiden van de rationalistische traditie waarin het toekomstonderzoek tot voor kort heeft gestaan. Er is sprake van een paradigmadiscussie, zowel bij de strategische beleidsmakers die opdracht tot verkenning geven als bij de verkenners zelf. Aan de kant van het strategisch beleid is er de niet aflatende discussie over sturingsconcepties, meer in het bijzonder of en, zo ja, in welke mate de zelfkritische functie van verkenningen toegelaten kan worden. Aan de methodologische kant is de vraag wat de betekenis is van 'feiten' in het toekomstonderzoek. De twijfel aan de waarde van voorspellingen in een dynamische samenleving is bekend. Zelfs de economische groei van volgend jaar kan slechts met een foutmarge van vele tientallen procenten worden gegeven, laat staan de groei van de mobiliteit over 10 jaar, of de ruimteconsumptie in 2020 of 2030. Maar ook de inhoud van de feiten staat ter discussie. Is er wel een ruimtegebrek in de Rotterdamse haven, bestaat het broeikaseffect, vragen die steeds moeilijker lijken te beantwoorden. In het T\&O project wordt nagedacht over dit vraagstuk.

In het plan van aanpak van T\&o wordt een viertal paradigmatische posities in het debat over toekomstonderzoek en strategisch beleid onderscheiden naar een telkens veronderstelde samenhang tussen twee dimensies: een sturingsconceptie met aan het ene uiterste een hiërarchische benadering en het andere uiterste een marktbenadering, en ten tweede een kennisdimensie met aan de ene kant middelen en aan de andere kant waarden en normen. In ieder paradigma speelt kennis een bepaalde rol die samenhangt met de perceptie van de omgeving waarbinnen het strategisch beleid zich zou dienen te ontwikkelen. Na discussie is deze vierdeling teruggebracht tot een drietal sturingsposities. Daarbij is vastgesteld dat de methodologische opvattingen over de rol van wetenschappelijke kennis niet noodzakelijkerwijs samenhangen met een sturingsconceptie. In hoofdstuk 2 zal op de 
conceptuele aanpak van het ex-postonderzoek nader worden ingegaan. Een belangrijke reden om sturingsconcepties niet één op één met methodologische opvattingen te verbinden is dat daardoor de dynamiek in de onderlinge relaties moeilijker zichtbaar gemaakt kan worden.

De paradigmakeuze kan niet eendimensionaal worden gedefinieerd met aan de ene kant het verticale sturingsmodel, de overheid als boven de partijen staand gezag, en aan de andere kant een horizontaal model, de overheid als gelijkwaardige partij op de markt. Er wordt in het volgende hoofdstuk een derde positie onderscheiden die zich niet laat reduceren tot enerzijds de markt en anderzijds de overheid: netwerksturing. De klassieke benadering kent lineaire doel-middel redeneringen en de tweede spreekt de taal van de transactie (voor wat hoort wat). De netwerksturing gaat over vervlechting van netwerken, partijen en doelstellingen.

Aan de onderzoekskant is het onderscheid tussen weten, willen en kunnen meer voorop komen te staan. Wetenschappelijk onderzoek beperkt zich tot het vaststellen van de feiten. Toekomstverkenningen gaan vooral over onzekerheden. Weten, willen en kunnen vallen niet samen en verhouden zich in de loop van een beleidsproces steeds anders ten opzichte van elkaar. Toekomstverkenningen die worden opgezet om beleidsinnovatie te genereren kunnen niet blijven staan bij de feiten alleen. De geanalyseerde toekomstverkenningen zijn in dit opzicht illustratief.

Hoofdstuk 3 van de terugblik behandelt zes casus:

- Brabant 2050;

- Landbouwverkenningen Brabant, Scenario's voor landbouw en ruimtegebruik in Brabant;

- Natuurverkenningen;

- Nederland 2030

- Questa;

- Woonverkenningen.

Van elke verkenning wordt een typering gegeven van de begin- en eindsituatie in de termen van hoofdstuk 2. De belangrijkste knikken in de interne dynamiek worden opgespoord. Elke casus wordt afgesloten met een aantal bevindingen ten aanzien van de vervlechting van onderzoek en strategisch beleid.

In hoofdstuk 4 worden enkele conclusies geformuleerd die voortvloeien uit de toekomstverkenningen. Deze conclusies zijn aanleiding voor het formuleren van leerervaringen en mogelijke kansen voor een effectievere vervlechting van toekomstverkenningen en omgevingsbeleid. In het vervolg van de werkzaamheden van de Stuurgroep zullen deze kansen op effectievere vervlechting worden onderzocht in de ex-anteprojecten. 


\section{HET CONCEPTUEEL KADER}

\subsection{INLEIDING}

Het onderzoek richt zich op de vraag hoe zes recente verkenningstrajecten zijn verlopen. Met name komt de interactie van verkenners met beleidsmakers aan bod, alsmede de betekenis van de verkenning voor processen van beleidsontwikkeling. Strategisch omgevingsbeleid is het inhoudelijk domein van de verkenningen.

We zijn geïnteresseerd in deze vraag vanuit de aanname - gestoeld op eerdere studies - dat de verbinding van onderzoekstrajecten met beleidsprocessen te wensen overlaat, zelfs zodanig dat onderzoekers achterblijven met het gevoel beperkt te zijn in 'echte' verkenning en met de teleurstelling dat er weinig is gedaan met de resultaten. Beleid wordt in deze visie meer gebaseerd op bestaande machtsverhoudingen en de waan van de dag dan op een serieuze verkenning van de toekomst en een consequente keuze voor doelen en middelen. Het onderzoek wordt hierdoor vooraf ingeperkt, is de beleving. Onderzoek dat afwijkt van het beleid of aangeeft dat het beleid niet werkt, leidt zelden tot applaus vanuit de beleidswereld.

Beleidsmakers daarentegen hebben vaak het gevoel dat onderzoekers er niet in slagen om de beleidsrelevantie te doorgronden en daarmee rekening te houden in hun handelen. Er worden niet de vragen gesteld die van belang zijn in het beleidsproces, de timing is slecht en de conclusies van onderzoekers zijn vaak zo vaag of genuanceerd dat hiermee weinig valt te doen in beleidsprocessen. En als de resultaten van onderzoek al helder zijn, betreft het vaak een gespecialiseerd deel van de werkelijkheid. Ook hierdoor wordt de afweging in beleidsprocessen niet gefaciliteerd.

Kortom, er is sprake van een moeizame relatie tussen beide werelden. En toch hebben ze elkaar nodig. Onderzoek zonder benutting in het beleid is een mooie intellectuele zelfbevrediging, maar het verhoogt het kennisniveau van samenleving en beleid niet. Beleid zonder benutting van onderzoek is een mooi machtspolitiek spel, maar ook blind voor maatschappelijke dynamiek in preferenties, trends en zelfsturing. Het is om deze redenen dat we nagaan hoe toekomstverkenningen verlopen en hoe deze betrokken zijn op strategische beleidsprocessen. Vervolgens kan een analyse uitgevoerd worden bij hedendaagse actuele verkenningstrajecten. De kennis die daaruit voortvloeit zal aangeboden worden aan de betrokkenen in de verkenningsprocessen, op basis waarvan zij kunnen beslissen lopende processen wel of niet bij te sturen. Deze bijsturende activiteiten kunnen vervolgens weer object van analyse zijn. 
De onderhavige ex-postanalyses zijn uitgevoerd vanuit een specifiek conceptueel model. Dit hoofdstuk schetst dat model en bijbehorende operationaliseringen. Het model bestaat uit drie elementen:

- Het proces van toekomstverkenning als object van studie (paragraaf 2.2);

- Variabelen om processen van toekomstverkenning te reconstrueren en analyseren (paragraaf 2.3);

- Ideaaltypen om de toekomstverkenningen te beoordelen (2.4.)

\subsection{HET OBJECT VAN STUDIE: HET PROCES VAN TOEKOMSTVERKENNING}

De ex-postanalyse richt zich op trajecten, waarin de toekomst is verkend. We brengen deze trajecten in relatie tot beleidsprocessen, maar verrichten geen onderzoek naar deze beleidsprocessen zelf. Dit is een belangrijke inperking van de expostanalyse. De lezer treft geen uitspraken aan over het verloop van strategische beleidsprocessen en de rol van onderzoek daarbij, zoals het tot stand komen van het Nationaal Verkeers- en Vervoersplan of de Vijfde nota Ruimtelijke Ordening. Primair gaat het om het (meer afgebakende) proces van toekomstverkenning zelf. Analoog aan de focal organization benadering, waar een specifieke organisatie centraal staat in het onderzoek en andere organisaties alleen in beeld komen als ze met deze organisatie interacteren of belangrijk worden gevonden, zullen wij in deze studie het verkenningsproces centraal stellen en alleen aandacht besteden aan beleidsprocessen voor zover vanuit deze processen aanzetten zijn gegeven tot het onderzoek, interventies zijn gepleegd in het proces van toekomstverkenning en de resultaten van het onderzoek zijn overgedragen of benut zijn.

Onder een beleidsproces verstaan we reeksen wilsbeschikkingen van bestuurders en politici of door hen gemandateerde professionals, in de vorm van normatieve (wat wil ik) en finale (wat kan ik; waartoe ben ik bereid) uitspraken, en daaraan te koppelen handelingen door zichzelf of anderen. Door zulke reeksen komt beleid tot ontwikkeling. Om tot beleid te komen, dient de beleidsmaker te weten wat hij wil (de normatieve kennis) en hoe dat te bereiken (de finale kennis over de samenhang tussen norm en middel; instrumentenkennis wordt ook wel gezegd). Hij dient ook te weten hoe de omgeving waarin hij handelt zich ontwikkelt. Er is kennis nodig van de feiten.

Als het erom gaat vast te stellen wat de normen zijn, zijn we geneigd te spreken van een politieke wilsbeschikking. Als het erom gaat vast te stellen hoe de politieke normen te bereiken, zijn we geneigd te spreken van een professioneel beleidstraject. Als het erom gaat vast te stellen wat de feiten zijn, spreken we van onderzoek en verkenning. 
De drie-eenheid willen, kunnen en weten beschrijft de primaire oriëntatie in de drie werelden (figuur 1). Willen is een activiteit, waarbij beleidsmakers los van de werkelijkheid' kunnen ontdekken welke de preferenties zijn die zij willen bevredigen. Bij het kunnen gaat het erom gaat vast te stellen welke middelen ter beschikking staan om dat wat gewild wordt te realiseren. Niet alles wat gewild wordt blijft dan mogelijk, gegeven schaarste aan middelen.

\section{Figuur 1 Willen, weten en kunnen als de drie hoekpunten van beleidsprocessen}

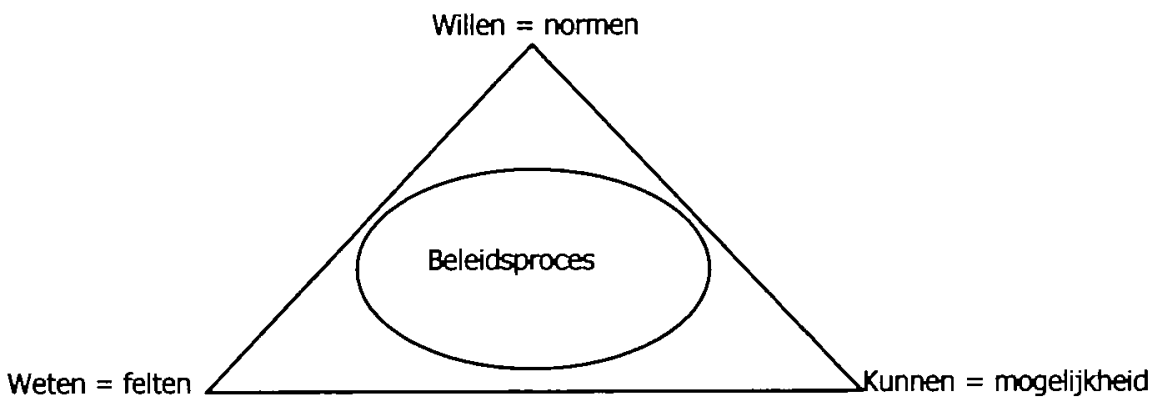

Willen en kunnen zijn moeilijk los van elkaar te zien. In de beleidspraktijk gaat het vaak om de tweeling "probleem" en "oplossing". Het weten staat hier enigszins los van. Weten is de samenhang der dingen begrijpen, zonder dat daarover direct behoeft te worden geoordeeld in termen van willen en kunnen. Het is waarschijnlijk vanuit dit soort beelden dat een scheiding is aanbracht tussen beleidsprocessen waar de nadruk ligt op het formuleren van wat de samenleving wil en het openbaar bestuur kan enerzijds, en processen waar weten en verkennen centraal staan anderzijds. De terugblik richt de aandacht op deze verkenningstrajecten. Deze trajecten moeten aan twee criteria voldoen, te weten:

1 Toekomstgericht zijn, met andere woorden naast het vaststellen van de 'feiten' in het heden of verleden, uitspraken willen doen over de toekomst.

2 Relevant zijn voor omgevingsbeleid, met andere woorden niet aangevangen zijn vanuit een puur wetenschappelijke nieuwsgierigheid, maar vanuit een beleidsmatige interesse. Deze trajecten zijn ook bedoeld als nieuwe input voor beleidsprocessen.

Een toekomstverkenning is met andere woorden een beleidsmatig geïnitieerd onderzoekstraject, waarin het weten wel in dienst staat van beleidsprocessen en beleidsmakers, maar er ook op enige (soms meer en soms minder) afstand van wordt opgezet en uitgevoerd. De aandacht richt zich op de manier waarop, en de intensiteit waarmee, de onderzoekstrajecten zijn vervlochten met beleidsprocessen. 


\subsection{VERKENNINGEN RECONSTRUEREN; OVER INTERACTIES, ACTOREN, PERCEPTIES EN PRODUCTEN}

In de ex-postanalyses gaat het er primair om te achterhalen hoe het proces van toekomstverkenning is verlopen. Een proces van toekomstverkenning is te beschouwen als een opeenvolging van interacties ${ }^{1}$ tussen actoren, die handelen uit verschillende percepties aangaande behoefte aan bepaalde soorten kennis. Zij brengen daadwerkelijk kennisproducten tot stand, die vervolgens wel of niet gebruikt worden in beleidsprocessen van opdrachtgevers of andere actoren. Om de analyse uit te voeren is een nadere specificatie van de begrippen actoren, producten, percepties en interacties nodig.

\section{Toekomstverkenning als interactie tussen actoren}

In termen van actoren maken we onderscheid tussen de volgende vijf rollen:

- Beleidsmatig actieve actoren die optreden als opdrachtgevers voor een toekomstverkenning. Is duidelijk wie de opdrachtgever is en namens wie deze handelt en vanuit welke behoefte?

- Opdrachtnemers, die verantwoordelijk zijn (of zich voelen) voor kennisontwikkeling. Vaak zijn dit onderzoeks- of strategieafdelingen binnen ministeries, soms meer verzelfstandigde onderzoeksinstituten zoals RIVM en soms worden ook andere onderzoekers betrokken maar dan veelal voor deeltaken.

- Interventieplegers die tussen start en beëindiging van een kennisontwikkelingstraject belangrijke interventies plegen in het betreffende traject (soms zijn dit opdrachtgevers, soms anderen)

- Beleidsmatig actieve actoren die optreden als ontvanger van de producten van toekomstverkenning in de eerder geformuleerde verwachting dat deze ontvanger behoefte had aan de gegenereerde kennis.

- Alle actoren die waarneembaar gebruik maken van de producten van toekomstverkenning, ook als gebruik door deze actoren niet voorzien is door de opdrachtnemers en/of -gevers.

\section{Toekomstvenkenning als een reeks van kennisproducten}

Verder wordt in de reconstructie gebruikt gemaakt van het begrip kennisproduct. We onderscheiden drie soorten kennisproducten:

- Geëxpliciteerde kennisbehoefte. In welke mate hebben de opdrachtgever en de opdrachtnemer in de aanvang van de verkenning expliciet interactie tot stand gebracht over de aard van de kennisbehoefte en is deze op enigerlei wijze vastgelegd?

- Tussentijdse kennisgenererende producten. Welke tussenproducten heeft de verkenning opgeleverd, tot welke reacties heeft dat geleid en in welke mate zijn mede hierdoor buigingen opgetreden in het verkenningstraject?

- Eindproducten. Waarmee is de verkenning afgesloten en wat dient mogelijk als input voor beleidsprocessen? 
We gaan er vanuit dat in verkenningen, ondanks dat deze op enige afstand van beleidstrajecten staan, wel een vervlechting plaats vindt van willen, weten en kunnen. Het gaat dan om: het voorspellen van de toekomst, los van beleid (weten); het ontwerpen van samenhangende wenselijke toekomsten (willen); of het ontwerpen van haalbare toekomsten (kunnen). Vervolgens is bezien in welke mate dit onderscheid consistent is volgehouden en in welke mate er verwarring is ontstaan tussen partijen over de vraag of het om waarschijnlijke, wenselijke of mogelijke toekomsten gaat.

\section{Percepties op toekomstverkenningen}

Partijen handelen vanuit opvattingen over de rol en gebruik van toekomstverkenningen. Steeds wordt aangegeven wat de opvattingen zijn geweest van de verschillende actoren over hun eigen rol, de rol van anderen, de rol van de kennisproducten en de interactie die is georganiseerd om tot kennisontwikkeling te komen. Daarmee ontstaat enig zicht op de verschillen in verwachting, met name bij opdrachtnemers versus opdrachtgevers.

\section{Interactiepatronen}

Ten slotte geven we aan hoe de overdracht, of meer algemeen geformuleerd, de interactie tussen beleidsstroom en onderzoeksstroom geregeld was. We problematiseren het opdrachtgeverschap van het onderzoek, de helderheid van de onderzoeksbehoefte, de explicietheid en helderheid over de toepassing van het onderzoek en de benutting van de resultaten.

Concreet leidt dat tot een reconstructie van:

- Aanleiding en inhoud van het verkenningstraject

Om een beeld te krijgen van de verkenning, wordt allereerst nagegaan waar de aanleiding lag en welk hoofdproduct de verkenning heeft opgeleverd.

- De aard en wijze van het opdrachtgeverschap

De aard en de wijze van het opdrachtgeverschap, de mate waarin dit op schriftelijke wijze is vastgelegd, welke verwachtingen de opdrachtgever had.

- De invulling van het opdrachtnemerschap

Nagegaan is of de onderzoekers zich bewust waren van de interactie tussen willen, weten en kunnen en van de rol die beleidsmakers aan hen hadden toegedacht. Gaat het de onderzoeker om factfinding, om de ontwikkeling van consistente normatieve modellen, of om denkbare toekomsten met een interne logica, die als referentiemodellen het beleidsproces faciliteren.

- Het verloop en de organisatie van het verkenningstraject

Het verloop van de verkenning wordt in kaart gebracht om te verhelderen hoe de behoeften en interventies uit beleidsprocessen zijn verdisconteerd in de verkenning. We gaan na of er doelverschuiving plaats vindt in het onderzoekstraject, en wat de gevolgen daarvan zijn voor de resultaten en het gebruik van de verkenningen aan het eind van het onderzoekstraject.

- De overdrachtsregeling aan het eind van het onderzoekstraject. Is er een overdrachtsregeling en zijn verkenners en beleidspartijen zich 
bewust van de manier waarop ze kennis overgedragen. Gebruiken ze rapporten en beklijven deze. Benut men levende kennis (in de hoofden van participanten in het onderzoekstraject) en wordt deze kennis behouden in beleidstrajecten.

- Resultaten en benutting

Wat waren belangrijke resultaten van onderzoek (kennis in hoofden, die zijn ingezet in beleid; kennis in rapporten die daarna in de kast verdwenen of agendavormend werkten) en wie heeft er wat aan gehad. Ook bezien we waar kennis niet is benut, terwijl daar verwachtingen over waren.

Figuur 2 Thema's en variabelen bij de reconstructle van verkenningstrajecten

\begin{tabular}{|l|l}
\hline Onderzoeksthema & Kernvartabelen \\
\hline Karakter toekomstverkenning & $\begin{array}{l}\text { Typering van de aanleiding en het domein waarop onderzoek } \\
\text { betrekking had en een beeld van de meest pregnante } \\
\text { kenmerken. } \\
\text { Opdractitgever, wijze van opdracht geven, kennisdoel van } \\
\text { opdractitgever, betrokkenheld bij onderzoek. }\end{array}$ \\
Invulling door opdractinemer & $\begin{array}{l}\text { Opdrachtnemer, wijze van opdracht nemen, kennisdoel dat } \\
\text { werd nagestreefd, gerichtheid op beleidsprocessen. } \\
\text { Procesontwerp, onderzoeksproducten, knikpunten in verloop } \\
\text { van toekomstverkenning door interactie beleid en onderzoek } \\
\text { en / of door exteme dynamiek. } \\
\text { Beeld over overdracht, explidtering van de } \\
\text { overdractitsregeling en optredende problemen, zorg voor } \\
\text { consolidatie opgedane kennis, afspraken over moment en } \\
\text { aard van de benutting. } \\
\text { Verwachte gebruik, feitelijk gebruik, wijze van gebrulk en } \\
\text { soort gebruikers versus verwachte gebruikers }\end{array}$ \\
\hline
\end{tabular}

\subsection{IDEAALTYPEN OM TOEKOMSTVERKENNINGEN TE BEOORDELEN}

Eerder is gesteld dat verkennen (het weten) een beetje een buitenbeentje is in de relatie met kunnen en willen (figuur 1). Voor veel beleidsmakers staat het weten in dienst van het willen en kunnen. Hoewel verkenners het hier niet mee eens hoeven te zijn en een sterk punt hebben, daar waar ze verkenningen presenteren als een counter failing power die kan knagen aan onjuiste fundamenten van huidig en toekomstig beleid, willen we de toekomstverkenningen vooral beoordelen in het licht van hun bijdrage aan beleidsprocessen. Deze beoordeling kan plaats vinden vanuit twee optieken:

1 De optiek van beleidsmakers zelf;

2 Een externe onderzoeksmatige optiek.

We benutten beide optieken in de evaluatie van de verkenningen. In de casusbeschrijvingen zelf geven we aan met welke verwachting de betrokken beleidsmakers naar de verkenningen keken, zowel in de aanvangsfase, als (via interventies) tijdens het proces, als in de wijze waarop de kennis is benut in vervolg- 
trajecten. Verder zullen we in het hoofdstuk volgend op de vijf casusanalyses een vergelijkende analyse uitvoeren. Deze bevat de variëteit aan opvattingen die beleidsmakers ten toon spreiden in hun optiek op de verkenning, alsmede een vergelijkend oordeel vanuit de onderzoekers. Om beide componenten van de evaluatie uit te voeren, presenteren we in deze paragraaf een drietal ideaaltypen van de relatie tussen willen, kunnen en weten. Dit zijn achtereenvolgens:

- Het hiërarchische model, waar het weten in dienst staat van het willen

- Het transactiemodel, waar het weten in dienst staat van het kunnen

- Het netwerkmodel, waar weten, kunnen en willen vervlochten zijn als een proces.

\section{Flguur 3 Drie Ideaaltypen van de relatte tussen willen, weten en kunnen}

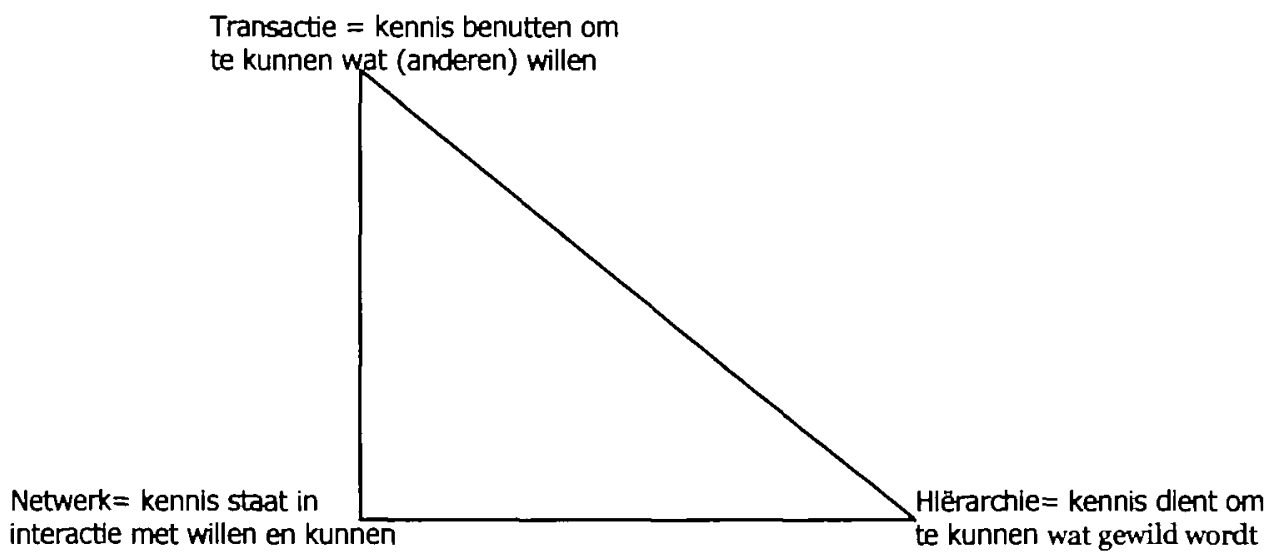

\section{Het hlërarchische model: het willen centraal}

In het hiërarchische model, normaliter geprojecteerd op het publieke domein, bestaat het primaat van de politiek, dat zonder last en ruggespraak het algemeen belang dient. In deze optiek gaat de "wils" beschikking van de volksvertegenwoordiger vooraf aan de vraag wat kan. ${ }^{2}$ De gulden regel luidt dat als de gekozene iets wil, de ambtenaar zijn professionalisme inzet om dat mogelijk te maken.

De onderzoeker is weer dienstbaar aan beiden. Hij verzamelt kennis over de mate waarin de werkelijkheid (nog) afwijkt van de wilsbeschikking en over wat gedaan moet worden om deze afwijking op te heffen. Onderzoek wordt niet ingezet te worden om het willen te bekritiseren. 
Figuur 4 Ideaaltype van het hiërarchische model: verkennen in dienst van het willen

\begin{tabular}{|l|}
\hline $\begin{array}{l}\text { Beleidsmakers } \\
\text { doen normatieve } \\
\text { uitspraken }\end{array}$ \\
\hline $\begin{array}{l}\text { Professionals } \\
\text { dragen oplossing } \\
\text { aan en voeren uit }\end{array}$ \\
\hline $\begin{array}{l}\text { Onderzoekers } \\
\text { doen empiristche } \\
\text { uitspraken }\end{array}$ \\
\hline
\end{tabular}

Onderzoekers produceren kennis over maatschappelijke trends, die politici benutten om vast te stellen waar de werkelijkheid afwijkt van de wil, en waar actie noodzakelijk is; Onderzoeker produceren kennis over wetmatigheden dle professionals benutten om vast te stellen wat er mogelijk is.

Beleidsmakers die handelen vanuit dit schema hanteren een hiërarchisch model. Onderzoekers dienen via methodisch verantwoord onderzoek feiten vast te stellen in dienst van de politieke doelen. De doelen worden geacht duidelijk te zijn. De feiten helpen politici om vast te stellen waar afwijkingen van de norm optreden en er dus gestuurd moet worden. Ook kunnen deze feiten helpen vast te stellen wat een geschikt instrumentarium is om de werkelijkheid aan de wens aan te passen. Omdat het willen het primaat heeft, kan het een tamelijk stabiel karakter hebben (regeerakkoord, nota ruimtelijke ordening). Omdat het willen in grote lijnen vastligt kan de verkenning kijken of de ontwikkelingen de wensen volgen en, zo niet, waarom niet.

\section{Het transactiemodel: het kunnen centraal}

Het transactiemodel is gebaseerd op de marktmetafoor. Op een markt ontmoeten de klant (hij die een product of dienst 'wil') en de producent (hij die iets kan) elkaar op vrijwillige basis. De producent maakt iets op eigen gezag en kosten, waarvan hij verwacht dat de klant daaraan behoefte heeft. De klant is vrij om te bepalen of hij dat product wil. De producenten zijn vrij om klanten te zoeken. Als ze elkaar vinden treedt een transactie op. In tegenstelling tot het hiërarchische model is het bij transactie niet ongebruikelijk dat het kunnen vooraf gaat aan het willen. Als behoeften nog niet bestaan, kan de producent pogen deze te kweken. In het transactiemodel staat het weten eerst en vooral in dienst van het kunnen. Kennis is nodig voor productinnovatie en voor de verbinding met het willen.

In het transactiemodel wordt de toekomst geschapen door het handelen van vele partijen en wordt in tegenstelling tot het hiërarchische model ook verondersteld dat geen der partijen in staat is om daarop een dominante invloed te hebben. De wilsbeschikking domineert niet de werkelijkheid. Wat een organisatie wil, hangt af van de trends en van de eigen mogelijkheden om daarop in te spelen (productinnovatie). Verkenningen zijn nodig om slimmer in te spelen op de trends. Omdat het willen van anderen centraal staat en het hier om een steeds veranderende 
target gaat, dienen verkenningen er met name ook toe om de eigen koers bij te stellen (adaptief vermogen versus sturend vermogen in het hiërarchische model).

\section{Het netwerkmodel: interdependentie centraal}

Decennia lang heeft de sturingsdiscussie zich voltrokken op de lijn van de klassieke hiërarchie en de klassieke transactie. De laatste decennia verschijnen er studies over een nieuw sturingsmodel dat elementen bevat van zowel hiërarchie als transactie, maar dat als een eigenstandige benadering is te beschouwen door de toevoeging van een karakteristiek die ontbreekt in de twee andere modellen, te weten interdependentie.

Daar waar de hiërarchie veronderstelt dat de wilsbeschikking van gekozenen het primaat heeft (lees autonomie) en daar waarin de markt alle partijen vrij zijn (lees autonomie) om transacties aan te gaan, gaat het netwerkmodel er vanuit dat geen der partijen zelfstandig in staat is om de eigen ambities te realiseren (lees interdependentie). Vanuit het netwerkmodel wordt de (problematische) relatie tussen beleid en onderzoek verklaard uit de toegenomen interdependenties.

In een netwerkmodel wordt verondersteld dat beleidsontwikkeling tot stand komt door voortdurende interactie tussen kunnen, willen en weten. De institutionele scheiding tussen het willen, weten en kunnen of de veronderstelde eenzijdige relatie, waarbij het weten ondergeschikt is aan het willen of kunnen, wordt ter discussie gesteld. In het netwerkmodel is vervlechting een kernelement van sturing. De aandacht richt zich op de vraag hoe vervlechting nu vorm krijgt en hoe en waar momenten en principes van scheiding worden toegepast. Het adequaat organiseren van processen van vervlechting zou in het netwerkmodel belangrijker worden voor sturing, dan bijvoorbeeld een eenduidige definitie van het probleem vooraf, of het op afstand zetten van onderzoek om de onafhankelijkheid te bewaren. ${ }^{3}$ Omdat het netwerkmodel een kortere traditie heeft dan de andere twee en daarom meer onderbouwing vereist, presenteren we hier kort drie aannames waarop het model is gebaseerd, die betrekking hebben op de samenhang en scheiding tussen verkenning en beleidsprocessen:

- Meervoudig wilsbeschikking.

Maatschappelijke wilsbeschikking wordt niet alleen in de politiek of via de markt bewerkstelligd, mar ook in en door meer complexe processen van interactie tussen markt, hiërarchie en civil society. Er wordt veel gewild, op veel plekken en daar wordt op die plekken ook naar gehandeld. Professionals en onderzoekers kunnen niet meer gerust zijn over de vraag wat de maatschappij wil. Door de dynamiek in preferenties krijgt dat wat zij aanbieden (feiten en mogelijkheden) een grotere bederfelijkheid.

- Meervoudige werkelijkheid en de strijd om feiten.

Trends in de samenleving lijken zich steeds meer te onttrekken aan het vermogen van onderzoekers om ze vast te stellen. Sommigen spreken van de ongekende samenleving. ${ }^{4}$ Feiten lijken steeds minder feiten. Of anders geformuleerd, er zijn tegenwoordig zoveel feiten, dat er keuzen moeten worden 
gemaakt die in toenemende mate arbitrair lijken te zijn. Ook worden feiten later opnieuw geordend en kan de vraag wat maatgevende feiten zijn veranderen.

- Vluchtige en dynamische beelden van (on)mogelijkheden.

De vraag naar het kunnen is in een samenleving waar de middelen verdeeld zijn over vele stakeholders niet meer enkelvoudig te beantwoorden. Er zijn ketens en netwerken van handelingen die bepalen wat er gebeurt in een netwerksamenleving en daarmee wat er mogelijk is. In deze ketens dient de vraag zich aan wat anderen willen en welke onvoorziene interventies door nieuwe wilsbeschikkingen en nieuwe feiten de beelden van (on)mogelijkheden beïnvloeden.

Het netwerkmodel heeft aandacht voor interdependentie, interactie en gemeenschappelijk belang. Als minder eenduidig is wat gewild wordt, wat kan en wat is, wordt een dynamische interactie en samenwerking tussen politici, beleidsmakers en vorsers voor alle betrokkenen belangrijk. Alleen zo zijn ze in staat om tot rationalisering van beleid te komen. Met het begrip situatiedefinities wordt benadrukt dat veel zogenaamde 'feiten' sociale constructies zijn, die min of meer breed worden gedragen. Ook wordt gesproken over probleemdefinities om aan te geven dat er meer dan één probleem bestaat in beleidsprocessen. De term oplossingsrichting wordt vaak gebruikt om speelruimte te creëren bij (wat traditioneel heet) de implementatie.

Figuur 5 Drie Ideaaltyplsche modellen voor sturing en beoordeling van verkenningstrajecten

\begin{tabular}{|c|c|c|}
\hline Het klassieke model & Het transactlemodel & Het netwerkmodel \\
\hline Het willen heeft het primaat. & $\begin{array}{l}\text { Het kunnen heeft het } \\
\text { primaat. }\end{array}$ & $\begin{array}{l}\text { Kunnen, willen en weten zjjn } \\
\text { verviochten. }\end{array}$ \\
\hline $\begin{array}{l}\text { Op basis van wilsbeschilkking wordt } \\
\text { vaststellen wat 'kan', ondersteund } \\
\text { door kennis over de feiten en } \\
\text { effecten van voorgestane } \\
\text { interventies }\end{array}$ & $\begin{array}{l}\text { Op basis van een verkenning } \\
\text { van (gaten in) de markt gaat } \\
\text { een producent bepaalde } \\
\text { producten maken, waartij } \\
\text { bezien wordt wat en wie } \\
\text { nodig is om dat te kunnen } \\
\text { maken }\end{array}$ & $\begin{array}{l}\text { Partijen bepalen op basis van } \\
\text { interdependenties wat ze } \\
\text { apart en gezamenlijk kunnen } \\
\text { / willen. }\end{array}$ \\
\hline $\begin{array}{l}\text { Beleid benut kennis om afwijken } \\
\text { van het willen en randvoorwaarden } \\
\text { voor het kunnen vast te stellen. } \\
\text { Onderzoekers vergaren feiten. }\end{array}$ & $\begin{array}{l}\text { Onderzoek dient om eigen } \\
\text { product beter te maken en } \\
\text { goed te presenteren bij } \\
\text { anderen die iets willen. }\end{array}$ & $\begin{array}{l}\text { Het weten ondersteunt het } \\
\text { zoeken naar haalbare combi- } \\
\text { naties van kunnen en willen. } \\
\text { Kennis is netwerkkennis; }\end{array}$ \\
\hline $\begin{array}{l}\text { Kennis is vast te leggen in een } \\
\text { rapport, heeft een aanzienlijke } \\
\text { levensduur en wordt niet heftig } \\
\text { betwist }\end{array}$ & $\begin{array}{l}\text { Kennis is bederfelijk omdat } \\
\text { de preferenties van afnemers } \\
\text { veranderen, ook onder } \\
\text { invioed van andere } \\
\text { producten. }\end{array}$ & $\begin{array}{l}\text { Diverse actoren construeren } \\
\text { in een complex interactie- } \\
\text { proces een aan plaats en tijd } \\
\text { gebonden hanteerbare mix } \\
\text { van weten, kunnen en willen. }\end{array}$ \\
\hline
\end{tabular}

In de casusanalyses wordt, waar mogelijk, aangegeven welk model door de betrokken beleidsmakers en onderzoekers gehanteerd lijkt te zijn. In de 
vergelijking tussen de casus wordt vervolgens ingegaan op de vraag wat voor soort verkenningstrajecten het meest past in het netwerkmodel als ideaal voor procesontwerpen in de ex-antefase en welke aandachtpunten voor verbetering van de exanteprojecten daaruit voortvloeien.

\subsection{SAMENVATIING}

In dit hoofdstuk is het conceptuele model ontvouwd. Aangegeven is dat de expostanalyse zich richt op zes verkenningstrajecten die in de jaren ' 90 hebben plaats gevonden. Al deze trajecten zijn ingezet om een bijdrage te leveren aan strategisch omgevingsbeleid van een of meer overheden. In het volgende hoofdstuk zal per casus een reconstructie worden uitgevoerd. Daarbij wordt aandacht besteed aan de aanleiding tot de verkenning, de invulling van opdrachtgever- en opdrachtnemerschap, het verloop van het verkenningstraject, de overdrachtsregeling met beleidsmakers en het gebruik van de verkenning. Tevens wordt de verkenning beoordeeld in het licht van de door beleidsmakers en verkenners gehanteerde sturingsmodellen. In de vergelijkende studie die volgt op de zes casusstudies wordt het verkenningsproces als geheel beoordeeld in het licht van het netwerkmodel. 


\section{NOTEN}

1 Uiteraard kunnen partijen acties nemen zonder interactie met anderen. We richten ons hier evenwel op handelingen die ook door andere partijen zijn herkend en beantwoord.

2 Het is ook niet voor niets dat in de bestuurskunde studies verschenen over implementatieproblemen bij beleidsprocessen. Deze zijn constateringen dat wat de politiek wil niet blijkt te kunnen.

3 Ten overvloede wordt vermeld dat het hier gepresenteerde netwerkmodel niemand belet de resultaten te interpreteren en benutten vanuit een hiërarchische of transactionele sturingsvisie.

4 Zie het concept van 'De Ongekende Samenleving' (DOs) in H. van Gunsteren en E. van Ruyven (red.) Bestuur in de ongekende samenleving, Den Haag, 1995. 


\section{DE CASUS}

\subsection{BRABANT 2050}

\subsubsection{INLEIDING}

"Met behulp van de visie van een aantal prominente mensen moest de discussie over de toekomst in de Brabantse samenleving los komen."

De opdrachtgever voor het project Brabant 2050 was Gedeputeerde Staten van de Provincie Noord Brabant. De projectgroep Brabant 2050 bestaande uit medewerkers van de Provincie was de eerste opdrachtnemer. In oktober 1997 werd het eerste product Brabant Manifest 2050 gepresenteerd. Daarna ging de tweede fase van start en kwam er een nieuwe projectgroep.

Brabant 2050 had onder andere als aanleiding de ontwikkelingen op het terrein van de ruimtelijke ordening, onder meer het project Nadere Uitwerking Brabantse Steden (NUBS). In vijf steden zijn bijeenkomsten georganiseerd om over de toekomst van de stad na te denken. Mede op verzoek van de grote steden is besloten om de inhoud van Manifest Brabant 2050 niet tot ruimtelijke ordening of fysieke infrastructuur te beperken, maar ook aan sociale en culturele componenten aandacht te geven. Het Brabant Manifest 2050 getuigde van een groeiend zelfbewustzijn in Brabant. Dat de Provincie een overloop gebied leek voor de Randstad, daar namen velen geen genoegen mee. ${ }^{2}$

Bovendien bleek dat Van Geel als bestuurder behoefte had aan een stevig maatschappelijk debat om de kwaliteit van de interne discussies, en de besluitvorming te verbeteren. ${ }^{3}$ Het bestuur van de Provincie Brabant wilde breed in Brabant discussies stimuleren die vanuit het oogpunt van een duurzame toekomst van de Provincie van belang zijn. Het koos daarbij voor een onorthodoxe aanpak. Op basis van de wetenschappelijk onderbouwde mogelijke, wenselijke en waarschijnlijke toekomstbeelden moest een discussie losgemaakt worden in de Brabantse samenleving in de wereld van dienstverlening, overheid en bedrijfsleven. Deze reacties zouden gebruikt kunnen worden in de voorbereiding van het Streekplan.

Het Manifest 2050 is door de projectgroep samengesteld en uitgegeven als 'Brabant op tafel' die als een doos op tafel gezet kon worden. Deze uitgave bevatte het Manifest 2050 met ontwikkelingen en visies op de toekomst van Brabant, 'Brabant ongemonteerd', een bundel essays en de wetenschappelijke onderbouwing van het Manifest, en drie posters van de Brabantse Woonatlas. 4 In het kader is kort de inhoud van het Manifest weergegeven. 


\section{Kader 1 Brabant Manifest 2050 in vogelviucht s}

\section{Het Manifest}

Het Manifest Brabant 2050 gaat over veranderingen in de toekomst van Brabant en het is ondertekend door achttien prominente Brabanders en andere Nederlanders.

Het jaar 2050 is het ijkpunt en er worden vier taboes doorbroken: (1) Brabant is geen platteland meer

(2) het nederzettingenpatroon, ook wel de sterrenhemel of nevel genoemd, heeft brede steun onder de bevolking (3) leefstijlen komen in plaats van buurten en wijken (4) er komen snelfietspaden.

Tien onderwerpen komen aan bod. Daarvan wordt de waarschijnlijke, mogelijke en gewenste toekomst besproken.

De thema's die besproken worden zijn: globalisering van de economie en cultuur; maatschappelijke tweedeling; kunnen cijfers liegen?; wordt de wereld de maat van alle dingen; zijn er zwakke punten; de prijs van brandstof; de $\mathrm{CO} 2$ en welvaart; botsende economieën; politieke EU; ruimtelijke ontwikkeling. Op tussenbladen staan uitspraken van de prominente Brabanders over deze thema's.

Tot slot komt men in het Manifest tot een voorstel voor zes concrete projecten voor een duurzame toekomst van Brabant: (1) de oprichting van een indexcenter Brabant (2) een duurzame logistiek (3) het schoonmaken van de industrie (4) een snelfietswegnet voor heel Brabant (5) een gedragscode voor de landbouw (6) aankoop en bebossing van de inzijggebieden van de Brabantse beken. De projectgroep stelt ook voor om het denken over de leefomgeving op gang te brengen met de volgende drie initiatieven: een opdracht te verstrekken aan een aantal bekende architectenbureaus om, zowel voor de landschappelijk inpassing als de architectuur van de stallen van nieuwe grootschalige varkenshouderijen, een ontwerp te maken; tegenover de afname van de kwaliteit van leefomgeving stelt de projectgroep 'leefstijlen' om segregatie te voorkomen; de taaie problematiek van ruimtelijke kwaliteit 'stap voor stap' te verbeteren door nieuwe eenvoudige spelregels.

Naar aanleiding van het succes van 'Brabant op tafel' is besloten om een tweede fase aan de opdracht toe te voegen. Op uitnodiging van het Provinciebestuur werd een stuurgroep samengesteld die samen met een platform de opdracht kreeg om de discussie over het Manifest te faciliteren en stimuleren. In de afgelopen twee jaar hebben meer dan 80 bijeenkomsten plaatsgevonden, waaronder een reeks van 'verrassende ontmoetingen in Brabantse gemeenten'. Deze fase is afgesloten op 28 januari 2000 met een Manifestatie.

Er is een aantal concrete projecten voortgekomen uit het Manifest. Eén daarvan is het Centrum voor Duurzaamheid Telos. Dit is een samenwerkingsverband van de Katholieke Universiteit Brabant, de Technische Universiteit Eindhoven, het Provinciaal Opbouworgaan, ETTN (Economisch Technologisch Instituut) en de Provincie. Dit centrum gaat het maatschappelijk debat over duurzaamheid voortzetten, informatie verzamelen en onderzoek doen. Telos gaat onder andere een nulmeting verrichten om te kunnen achterhalen of de inspanningen op het gebied van duurzame ontwikkelingen effect hebben (project millennium kapitaal).

Bovendien heeft de Provincie 'een pot met geld gespaard voor toekomstgerichte projecten'. 6 Dit is het Ontwikkelingsfonds Brabant 2050 dat jaarlijks wordt aangevuld, is gereserveerd voor grote majeure projecten, waaronder Telos, Vitaal Grijs 
en Duurzame Bedrijventerreinen. Tijdens de manifestatie op 28 januari als afsluiting van de tweede fase in januari 2000 is ook een aantal Manifest projecten van start gegaan. Ook is de oproep gedaan om het proces voort te zetten.

\subsubsection{DE PERCEPTIE VAN DE OPDRACHTGEVER}

De opdracht kwam van de Gedeputeerde voor ruimtelijke ordening, Dhr. Van Geel van de Provincie Noord Brabant. Hij heeft het initiatief genomen voor de visieontwikkeling. Daarbij heeft het project politieke ruimte gekregen van de opdrachtgever en het moest voornamelijk 'mogelijke' toekomstbeelden opleveren: "Heel klassiek zou zijn om de wensbeelden van 2050 te formuleren, dat is niet gebeurd! Wij hebben mogelijke beelden opgeroepen van situaties die mensen bijna niet herkennen." 7

Uitgangspunt van de opdrachtgever was dat met hulp van een aantal 'denkers', bepaalde noties en wenselijkheden bedacht konden worden over de toekomst die zij zelf niet zouden bedenken.

Binnen het Provincieapparaat en in de Brabantse samenleving moest met het Manifest de visievorming gestimuleerd worden. Zodat dit niet alleen door een klein clubje Provinciebestuurders zou gebeuren maar ook door geïnteresseerde Brabantse burgers. "Daarvoor is in het college het 'spel' breed gehouden." 8

\subsubsection{PERCEPTIE VAN DE OPDRACHTNEMER}

De opdrachtnemers waren twee opeenvolgende projectgroepen Brabant 2050. De eerste heeft Het Manifest geproduceerd en verspreid. Na de presentatie van het Manifest in oktober 1997, is in januari 1998 het vervolgproject van start gegaan in een samenwerking met de stuurgroep en het platform. Deze tweede groep kreeg als taak om de discussie in de samenleving aan de hand van het Manifest te faciliteren.

Bij het produceren van het Manifest en het monitoren van de discussies stuurde de projectgroep zo min mogelijk de inhoud van de discussie. Dat hebben zij aan bekende Brabanders en wetenschappers overgelaten. In het Manifest zijn de waarschijnlijke, wenselijke en mogelijke toekomst doelbewust ontvlochten. De waarschijnlijke toekomst is in het Manifest de kleine cirkel genoemd. Daaromheen ligt de mogelijke toekomst in een iets grotere cirkel: 'de toekomsten die minder waarschijnlijk zijn maar met het 'boerenverstand' niet uit te sluiten zijn'. De derde cirkel bevat de gewenste toekomst. Dit zijn de dromen en idealen. 'De gewenste toekomst ligt deels in de waarschijnlijke en deels in de mogelijke toekomst. De gewenste toekomst ligt ook deels in de onmogelijke toekomst'. ${ }^{9}$ In de vormgeving zijn deze cirkels terug te vinden: de witte pagina's bevatten de mogelijke toekomst, op de zwarte pagina's zijn de mogelijke en waarschijnlijke toekomst terug te 
vinden. Met deze geschetste toekomstbeelden moesten creatieve, fantasievolle en onorthodoxe oplossingen voor waarschijnlijke of mogelijke problemen in de toekomst gegenereerd worden. ${ }^{10}$

In de ogen van een opdrachtnemer kreeg het project veel politieke ruimte waardoor deze opzet vergemakkelijkt werd. Brabant 2050 is bijvoorbeeld als innoverend project door de opdrachtgever bewust buiten de lijn van de organisatie geplaatst zodat het genoeg ruimte zou krijgen. Dat had twee redenen:

1 de bezorgdheid van een aantal bestuurders over de toekomst van de Provincie;

2 de weinige bekendheid van de Provincie als organisatie. "Bijvoorbeeld Commissaris van de Koningin Houben en gedeputeerde Van Geel maakten zich zorgen over de toekomst." 11

\subsubsection{DE ORgANISATIE VAN HET ONDERZOEKSTRAJECT}

"Het proces is incremented en niet planmatig opgezet "

Brabant Manifest is in tegenstelling tot de Scenario's voor landbouw en ruimtegebruik niet in een interactie met actoren uit de beleidssector tot stand gekomen. Pas nadat het product voltooid was, is het met die actoren bediscussieerd. Wel hebben wetenschappers, bestuurders en andere prominenten met essays en onderzoek bijdragen geleverd. In het Manifest is niet de visie van de Provincie opgenomen maar is men gestart 'met de visies van mensen van buiten het Provinciehuis' met de oproep om Brabant een spiegel voor te durven houden. In aanvang van het project was het communicatietraject een heikel punt. Volgens de opdrachtnemers werden beslissingen door de opdrachtgever daarover uitgesteld omdat door belangentegenstellingen in de provinciale organisatie er weinig oog was voor de interne en externe communicatie. De opdrachtgever is van mening dat hierover geen beslissing is genomen op advies van een interne communicatieadviseur. ${ }^{13}$

Door het gebrek aan directe communicatie over het Manifest werd persoonlijke inbreng van medewerkers belangrijk voor de slaagkans van het project: "Op medewerkerniveau is er veel medewerking aan het project geweest maar dat is nog geen commitment van de hele organisatie." 14

\section{Buigpunten}

Een buigpunt in het proces was de beslissing om de discussie over een duurzame toekomst van Brabant actief te gaan stimuleren en faciliteren begin 1998. Dit besluit werd genomen vooral na reacties van actoren uit de Brabantse samenleving. Er was met name commentaar op de topdown benadering: het 'van bovenaf droppen' van visies van prominente mensen. Dit blijk uit krantenartikelen uit het Brabants Dagblad en uit een interview met de projectgroep: “Misschien waren in 
aanvang van het project die negatieve reacties op de parachutering van die visies voorzien, maar het kan een leerproces van de Provincie zijn geweest." 15

Het projectbureau kreeg een nieuwe taak, samen met een stuurgroep en het platform 2050. Zij moesten de actoren actief gaan opzoeken en aan het woord laten. De opdracht voor de tweede fase is aanvankelijk op een 'open' manier door de opdrachtgever geformuleerd, bijvoorbeeld zonder eindtermijn en beoogde resultaten. Het projectteam zelf heeft hier invulling aangegeven en gaandeweg zijn er afspraken gemaakt met het Provinciebestuur. Het projectteam ging 'het monitoren van de maatschappelijke stemming' ${ }^{16}$ faciliteren en organiseerde discussies, de 'verrassende ontmoetingen' waaruit wensbeelden en mogelijke toekomsten die in de samenleving leven, naar voren moesten komen.

Daartoe is door het projectbureau een reeks van provinciale bijeenkomsten georganiseerd over onder andere de toekomst van de zorg, de landbouw en communicatie. In samenwerking met Lokale Agenda 21 zijn de 'verrassende ontmoetingen' georganiseerd. En vele bijeenkomsten van maatschappelijke organisaties, lokale overheden en anderen zijn gefaciliteerd. Hierbij is ook gebruik gemaakt van communicatiemiddelen zoals de radio en televisie.

Het Manifest is als middel in dit communicatietraject belangrijker geworden. Voor de Provincie is duidelijk geworden dat, zeker op lange termijn, zij over haar eigen functioneren moet nadenken. In het plan van aanpak van 17 juni 1999 wordt gesproken van het "zoek de burgers op". Er wordt meer van buiten naar binnen gewerkt. ${ }^{17}$ Dit blijkt ook uit een interview: “Het is te merken dat politici moeten wennen aan de wensen vanuit de samenleving. Dat de politiek niet het centrum van de wereld is en dat zij een partner is net als anderen." 18 Bovendien hebben de deelnemende organisaties, andere actoren, de weg naar de Provincie gevonden. Zij hebben een concrete vraag aan de Provincie voor de ondersteuning en facilitering van discussies.

De uitkomsten van de tweede fase zijn dus gepresenteerd, onder andere aan de bestuurders van de Provincie. Wellicht volgt hier een tweede buigpunt op. Belangrijk aanknopingspunt daarvoor is dat de Brabantse gemeenten hebben aangegeven "het stokje van Brabant 2050 over te willen nemen." 19

\subsubsection{DE ORGANISATIE VAN DE OVERDRACHT}

"Een van de grote charmes van dit project is geweest dat alles niet zo van tevoren heeft vast gestaan. Dat er een aantal mensen waren die dwars tegen alle conventies in dit plan hebben gemaakt. 20

In de startpositie zou de overdracht van kennis op basis van 'Brabant Op Tafel' gebeuren. De overdracht verliep alleen van de Provincie naar actoren in de dienstensector, overheid en bedrijfsleven. 
De opdrachtgevers en opdrachtnemers hebben wel nagedacht over een uitgebreider communicatietraject maar de opdracht voor de facilitatie van de discussie met meer actoren is toen niet verstrekt. ${ }^{21}$ Ook de communicatie over het project met de interne organisatie was niet vastgelegd. De input voor andere trajecten van beleidsvoorbereiding of voor het ruimtelijk beleid stond niet vast. $\mathrm{Er}$ is wel nagedacht over de vraag of het Brabants Manifest als input gebruikt zou worden voor de Scenario's voor landbouw en ruimtegebruik in Brabant 2050, of andersom. De trajecten zijn uiteindelijk toch afzonderlijk gestart en hebben elkaar hooguit geīnspireerd.

Na de tweede opdrachtverstrekking, begin 1998, kreeg de overdracht van kennis meer aandacht. Die overdracht moest verlopen via discussies. In aanvang is niet in een procesarchitectuur vastgelegd wat er met de kennis die dit opleverde zou gaan gebeuren in de beleidsvoorbereiding. De directe terugkoppeling van resultaten uit de discussie, dus wat gaan de Provincie, of anderen, doen met de informatie, was lang niet voorzien. De projectgroep was in september 1999 van mening dat dit wel moest gaan gebeuren: "Het bestuur moet wel iets doen met wat uit de discussies komt." 22 In de vorige paragraaf zagen we dat de overdracht vooral in projecten plaats vindt en op lokaal niveau door bijvoorbeeld gemeenten.

\subsubsection{BENUTIING VAN DE RESULTATEN VAN DE TOEKOMSTVERKENNING}

De toekomstverkenningen hebben de documenten uit 'Brabant op Tafel', waaronder het Manifest en 'Brabant Ongemonteerd' voortgebracht. Die zijn overgedragen aan de Brabantse samenleving en binnen de organisatie. Discussies daarover hebben voornamelijk kennis in hoofden opgeleverd bij deelnemers. Ook zijn de documenten binnen de provinciale organisatie als inspiratiebron gebruikt, onder andere door het projectteam van 'Over ruimte gesproken', dat zich met de voorbereiding van het Streekplan bezig houdt. Bovendien gebruiken zij het netwerk in de Provincie dat met het Manifest is opgebouwd. ${ }^{23}$ Ook het project 'Ontwerpen aan Brabant komt direct voort uit Brabant 2050'.

Een belangrijke conclusie voor de Provincie uit de eerste fase was dat vooral in projecten gewerkt zou moeten worden zodat men kon blijven leren: “Er moeten nieuwe toekomstgerichte projecten gegenereerd worden die de toekomst dichterbij brengen, maar niet gericht zijn op het eindbeeld." ${ }^{24} \mathrm{Om}$ deze nieuwe werkwijze te faciliteren zijn er twee producten voortgebracht: een Duurzaamheids Centrum en een ontwikkelingsfonds voor toekomstgerichte projecten. Het Duurzaamheids Centrum Telos gaat de discussie in de Brabantse samenleving voortzetten, informatie verstrekken en nulmetingen houden.

Of en hoe de kennis ook in nieuwe beleidsdocumenten terug te vinden zal zijn, is nog onduidelijk. Het streekplan is nog niet voltooid dus daar kan de kennis nog in gebruikt worden. De directe terugkoppeling van de resultaten uit de maatschappe- 
lijke discussie heeft plaatsgevonden eind januari. Het is nog te vroeg om uitspraken te doen over de benutting van de kennis uit die discussie.

\subsubsection{CONCLUSIE}

Het Brabant Manifest verkent denkbare toekomstbeelden. De opdrachtgever wilde de vorming van toekomstvisies stimuleren, zowel binnen als buiten het provinciale apparaat. De opdrachtnemers hebben met hulp van wetenschappelijke kennis en van visies van prominente Brabanders documenten geproduceerd met daarin wenselijke, waarschijnlijke en mogelijke toekomsten. Er is daarbij wel bewust een onderscheid aangebracht tussen deze drie categorieën, waarbij is erkend dat waarschijnlijk en wenselijk kunnen samenvallen, maar vaak ook los van elkaar staan.

Bijzonder aan deze verkenning is de activering van spraakmakende mensen aan het begin van het proces. Hun inbreng is in aanzienlijke mate agendavormend geweest. Hoewel dit wel tot enige kritiek heeft geleid in de media en bij sommige organisaties, had de aanpak als voordeel dat met name ook de denkbare, maar niet direct voor de hand liggende, toekomsten in beeld kwamen. De verrassingsgraad werd met andere woorden daardoor verhoogd. Dit gaat hand in hand met een verhoogd politiek risico. Burgers en media zouden immers de vraag kunnen stellen of de beelden nu wel of geen Provinciaal beleid zijn. Bij het Manifest heeft de opdrachtgever eerst de reacties afgewacht aleer verder te gaan met het verkenningstraject.

Het proces is op de tast vorm gegeven, waarbij de opdrachtgever en nemer in interactie steeds hun vervolgstappen hebben vastgesteld. De lijnen zijn daarvoor ook kort genoeg. Onder andere door deze platte structuur was het mogelijk om de verkenning te koppelen aan concrete projecten. Uit het gesprek met Van Geel bleek dat deze werkwijze ook een gevolg was van de toekomstverkenning in het Manifest en de tijdgeest.

Mede door de gelijktijdige ontwikkeling van toekomstbeelden in meer generieke zin en door de concrete projecten die behulpzaam zouden kunnen zijn om invulling te geven aan de wenselijke elementen van deze beelden, heeft de verkenning aan beleidsrelevantie gewonnen. Ook in deze verkenning heeft men tot op heden nog geen vernieuwende beleidsacties bedacht bij diverse toekomstbeelden die, in samenhang en over de grenzen van provinciale organisatieonderdelen heen, vorm hebben gekregen. Deze vernieuwing moet vooral inhoudelijk tot stand komen in nieuwe toekomstgerichte projecten. De provinciale toekomstverkenningen stuiten, evenals nationale verkenningen, met regelmaat op de organisatorische verkokering en domeinbewaking. 


\subsection{SCENARIO'S VOOR LANDBOUW EN RUIMTEGEBRUIK IN NOORD BRABANT}

\subsubsection{INLEIDing}

In 1996 verstrekte Gedeputeerde Staten van de Provincie Noord Brabant de opdracht voor de bouw van de Scenario's voor landbouw en ruimtegebruik in Brabant. In juni 1998 leverden DLO-Landbouw Economisch Instituut, DLO -Staring Centrum en Global Business Network (GBN), samen met een projectteam van de Provincie Noord Brabant, de scenario's.

De scenario's zijn een input voor het provinciale Streekplan, dat in 2002 gepresenteerd wordt maar hadden vooral tot doel de communicatie met de landbouwsector te bevorderen Daarnaast moesten beleidsmakers een nieuw denkkader voor de langetermijnvisie aangeboden krijgen. Dit kader moest bestaan uit scenario's van mogelijke toekomstontwikkelingen, die bovendien in de politieke discussies geïntroduceerd zouden worden.

Het communicatiedoel was om overeenstemming tussen de belanghebbende actoren te bereiken over de belangrijkste ontwikkelingen op lange termijn. Door samen vast te stellen wat mogelijke ontwikkelingen zijn voordat men over wenselijke oplossingen gaat discussiëren, moest een open gesprek op gang komen tussen actoren met tegengestelde belangen. Door de scenario's, volgens de Global Business Network-methodiek, met actoren in het veld samen te maken, werd overeenstemming over mogelijke toekomstige ontwikkelingen bereikt. Het bouwproces zou drie producten leveren:

1 aannames en kennis in hoofden;

2 de scenario's zelf, met daarin mogelijke toekomstige ontwikkelingen (zie kader 2);

3 een basisstrategie en beleidsopties. ${ }^{25}$

\section{Kader 2 Scenario's 'Onze Hof' en 'Brabant Globaal' In vogelviucht26}

\section{Onze Hor}

Boeren in Onze hof leiden een leven waarin het goede veel is en niet het vele goed. Zij werken veel samen. De productie is afgestemd op de draagkracht van bodem, water, natuur en landschap.

Landbouw is meer kennisintensief.

In dit scenario is er een consumentenvoorkeur voor kwaliteit. Er is een hoog milieubewustzijn en er is een sprongsgewijze technologische ontwikkeling waarbij risico's niet worden gemeden.

Solidariteit en duurzaamheid staan in deze samenleving centraal. Er is een sterke regionale oriëntatie. Het gezag van de centrale overheid neemt af en de regionale overheid krijgt een meer regisserende rol. Het gemeenschappelijk (internationaal) landbouwbeleid is geintegreerd in het economisch beleid dat is geintegreerd met milieu- en landschapsbeleid.

Noord Brabant is een volwaardig onderdeel van het Noordwest-Europees economisch kerngebied. 
Brabant is een veelkleurig palet van verschillende streken waarbij grote verschillen bestaan tussen bijvoorbeeld het kleinschalig zandgebied en het open zeekleigebied.

\section{Brabant Globaal}

Ondernemers in de agrosector zijn in dit scenario managers geworden voor wie inkomen en omzet bepalend zijn. Forse risico's moeten worden genomen om internationaal in de race te blijven. De concurrentie is groot en de vraag van de consument is grillig. Dat komt omdat in dit scenario de consument prijsbewust is en er een laag milieubewustzijn is. Er is een geleidelijke technologische ontwikkeling.

Zelfontplooiing en ondernemerschap worden hoog gewaardeerd. De overheid reguleert maar niet meer dan wat strikt noodzakelijk wordt geacht. Hierbij volgt zij in grote lijnen de Europese en mondiale afspraken. De overheid besteedt haar energie vooral aan het stroomlijnen van processen waarin veel ruimte is voor de visie van maatschappelijke groeperingen en private partijen.

Noord Brabant is een volwaardig onderdeel van het Noordwest-Europees economisch kerngebied. Indrukwekkende werklandschappen worden afgewisseld met woongebieden in verschillende dichtheden.

\subsubsection{DE AMRD EN WUZE VAN HET OPDRACHTGEVERSCHAP}

De opdracht is formeel door Gedeputeerde Staten van de Provincie Noord Brabant verstrekt. Het initiatief kwam met name van Van Geel die, als portefeuillehouder ruimtelijke ordening, een denkkader wilde voor de lange termijn, waarbinnen ook beslissingen van vandaag genomen konden worden.

Politieke conflicten tussen boeren en milieuorganisaties over het Streekplan in 1992 waren aanleiding voor scenariobouw met actoren uit het veld. Van Geel wilde een herhaling van de protesten voorkomen. Bovendien moest de stand still in de beleidsvoorbereiding doorbroken worden. ${ }^{27}$

Daarnaast voorzag Van Geel problemen voor de varkenshouderij en de glas- en tuinbouw in Brabant, zoals de verschuiving naar niet grondgebonden sectoren in de land- en tuinbouwsector en de discussies over ruimtegebruik in de Provincie. Door deze autonome ontwikkelingen te inventariseren met het veld zouden zij zich hier ook bewust van zijn. Van Geel wilde zo min mogelijk zijn politieke kleur in het beleidsvoorbereidende proces laten meespelen en heeft veel ruimte gegeven in het bouwproces. 28

\subsubsection{PERCEPTIE VAN DE OPDRACHTNEMER}

De opdrachtnemers kwamen voor een aanzienlijk deel van buiten de Provincie. Naast medewerkers van de Provincie hebben met name de (onderzoeks-) organisaties GBN, LEI-DLO en SC-DLo een bijdrage geleverd.

Het team van de Provincie was ambtelijk verantwoordelijk voor het project. Zij hadden de verantwoordelijkheden van de vier opdrachtnemers niet scherp gede- 
finieerd. Men dacht op die manier veel kennis aan elkaar over te kunnen dragen, met name aan de Provincie. Hierdoor werd echter onduidelijk wie waarvoor verantwoordelijk was. ${ }^{29} \mathrm{De}$ taakverdeling was ook niet formeel vastgelegd maar automatisch werd die gedeeltelijk gekoppeld aan de (formele) rol: projectteamleden van de onderzoeksinstellingen objectiveerden meer, de ambtenaren letten op de krachtsverhoudingen in de politiek en de provinciale organisatie. ${ }^{30}$

Het projectteam verzamelde feiten over bijvoorbeeld de ontwikkelingen voor de biologische landbouw, natuurbeheer en reservaatvorming, leeftijdsopbouw van de boeren en bijvoorbeeld het arbeidsvolume in de agro-business in Brabant. Deze vormden een basis voor de scenario's. Het team regisseerde en coördineerde bovendien het bouwproces van de scenario's. Men beoogde met de verkenning ook interactie tot stand te brengen met de beleidssector. Om dat te bereiken moest vastgesteld worden wat, in de ogen van actoren uit het veld, de meest invloedrijke omgevingsfactoren van de landbouw en ruimtelijke ordening voor de toekomst zouden zijn. ${ }^{31}$ Mogelijkheden en wensbeelden vanuit huidig beleid en de politiek moesten buiten de scenario's gehouden worden. Dit lukte over het algemeen goed, maar: “Zodra de beleidsmakers moesten terugkoppelen naar de schil om het projectteam, dan werd duidelijk dat organisatorische en politieke belangen wel een rol speelden. ${ }^{\text {} 32}$ Op basis van deze verzamelde gegevens en toekomstbeelden zijn twee scenario's gemaakt. Deze werden gebruikt als communicatie-instrument in discussies zodat gevoelige onderwerpen besproken konden worden met actoren die niet meer met elkaar rond de tafel wilden: "De scenario's waren nodig om te voorkomen dat de boeren met hun tractoren weer op de stoep van het Provinciehuis zouden staan." 33

Het resultaat van deze gezamenlijke 'ontdekkingstocht' moest ook een inspiratiebron zijn voor ruimtelijk beleid en het zou een netwerk van regionale sleutelfiguren in de land- en tuinbouwsector moeten opleveren. ${ }^{34}$

\subsubsection{DE ORGANISATIE VAN HET ONDERZOEKSTRAJECT}

In het verkenningstraject heeft regelmatige interactie tussen de opdrachtnemers en de actoren uit het beleidsveld plaats gevonden. “De scenario's moesten niet 'geparachuteerd' worden maar van onderaf gebouwd worden". ${ }^{35}$ Daarnaast is er tussentijdse afstemming geweest tussen de opdrachtgever en opdrachtnemer. Voorafgaande aan de opdrachtformulering is in 1996 door de opdrachtgever een brainstormdag georganiseerd. Samen met de onderzoeksinstellingen zijn een aantal trends en maatschappelijke ontwikkelingen in kaart gebracht die van invloed zijn op landbouw en ruimtegebruik in Brabant. ${ }^{36}$ Vervolgens zijn in interactie met de sector de onzekerheden en impliciete aannames over toekomstige ontwikkelingen vastgesteld. Tegelijkertijd werd in bijeenkomsten met de sector getest of de toekomstbeelden die geconstrueerd waren door de verkenners consistent en 
plausibel waren. Op basis van deze interactie zijn de scenario's steeds opnieuw gedefinieerd.

Een aantal sleutelfiguren uit de Provincie leverden in interviews de eerste bouwstenen. Daarna zijn er workshops geweest met ongeveer veertig ambtenaren. Het projectteam had in deze ronde moeite om verschillende beleidssectoren in de Provincie te betrekken omdat 'Medewerkers in hun eigen wereld bezig waren.' 37 Ook zijn er ketengesprekken georganiseerd met actoren uit verschillende sectoren van de landbouw. En op een drietal regiobijeenkomsten zijn de opties voorgelegd aan een aantal verschillende maatschappelijke organisaties, zoals boeren-, landen tuinbouw, milieu-, natuur- en consumentenorganisaties. De natuur- en milieuorganisaties en de consumentenorganisaties waren moeilijk te motiveren En, pas na een inspanning van de opdrachtnemers, kwamen er meer vrouwen naar de bijeenkomsten.

\section{Buigpunten}

Een buigpunt in het proces was het punt waarop de Provincie niet zelf beleidsopties heeft geformuleerd. Na voltooiing van de scenario's heeft een van de onderzoeksinstellingen deze taak op zich genomen. In eerste instantie was de bedoeling dat de medewerkers van de Provincie deze taak op zich zouden nemen. Terugkijkend zijn de opdrachtnemers van mening dat politici en ambtenaren op dat moment beter de trekkers van het proces kunnen worden. ${ }^{38}$ Door de invulling vanuit de verkenners is het proces te ver af komen te staan van de provinciale politici.

Eveneens onvoorzien was de relatief hoge inspanning in tijd en geld, die nodig was voor de verkenning. Hierdoor bleef er weinig financiële ruimte over om trendanalyses uit te (laten) voeren. Veel kennis in de scenario's is, onder andere daarom, gebaseerd op de informatie die uit het proces kwam. ${ }^{39} \mathrm{Er}$ is wel gebruik gemaakt van de CPB-scenario's en gegevens die LEI-DLO en SC-DLO voorhanden hadden.

\subsubsection{DE ORGANISATIE VAN DE OVERDRACHT}

De opdrachtnemers wilden kennis aan deelnemers overdragen via workshops en documenten. Dit was in aanvang van het proces de afspraak. In de discussies over onzekerheden en ontwikkelingen moesten deelnemende actoren, zoals boeren en hun vertegenwoordigers maar ook milieu- en consumentenorganisaties, gezamenlijk nieuwe denkkaders ontwikkelen over de toekomst van de landbouw.

In de overdracht van kennis waren de scenario's een instrument: “De scenario's zijn geen toekomstonderzoek. De scenariomethode is een manier om impliciete beelden die leven in kaart te brengen en te zorgen dat mensen meer begrip hebben voor andermans beelden. "Tijdens het scenariobouwproces zouden mensen zichzelf leren relativeren zodat mensen niet meer wensdenken en blijven roepen ' $\mathrm{ik}$ 
hou niet van regen'. Mensen wordt geleerd te denken: 'als het dan toch regent, wat is dan mijn keuze?" 40

Beleidsmakers en politici zijn vooral geinnformeerd via documenten. De provinciale leden van het verkenningsteam zouden strategieën en beleidsopties uit de scenario's halen en daarmee het provinciale apparaat ingaan. "Het projectteam zou ook beleidsopties bedenken voor de overleving van de landbouwgebruikers in de twee scenario's. Daar zijn ook hele concrete acties voor bedacht." ${ }^{41} \mathrm{Ook}$ zou een discussinota door het projectteam geschreven worden. Deze stukken zijn geproduceerd maar voornamelijk door een onderzoeksinstelling.

\subsubsection{BENUTTING VAN DE RESULTATEN VAN DE TOEKOMSTIERKENNING}

In de kennisoverdracht is vooral aandacht besteed aan de kennis en vaardigheden in 'hoofden'. De kennis opgedaan tijdens het bouwproces is door het projectteam ook in documenten vastgelegd en overgedragen. De strategieën en beleidsopties staan bijvoorbeeld in het stuk 'Meten met drie maten, een discussienota'. Ook is aan het einde van het traject een beleidsbrief gestuurd aan Provinciale Staten met daarin een denkkader voor het ruimtelijk- en landbouwbeleid. Tevens is deze brief in de schriftelijke communicatie tussen Gedeputeerde Staten en Provinciale Staten gebruikt.

De overdracht van kennis en vaardigheden in hoofden en de doelvervlechting tussen verschillende actoren tijdens het proces, is redelijk succesvol verlopen in de perceptie van de opdrachtnemers: "Het heeft goed gewerkt om eerst met betrokken partners mogelijkheden te verkennen en niet bij de eigen positie te beginnen. Dat was zeer vruchtbaar zeker voor de discussie en voor het bouwen van consensus." ${ }^{42}$ Deelnemers die voorheen niet meer met elkaar rond de tafel wilden zitten, waren nu wel bereid om samen vast te stellen wat mogelijke toekomstige ontwikkelingen voor de landbouwsector waren.

De onderzoekers en beleidsmakers in het projectteam hebben ook kennis opgedaan: zij zijn verrast en hebben geleerd van de inbreng van andere actoren. "Een verrassende inbreng in het bouwproces hadden m.n. alternatieve boeren. En ook de deelname van vrouwen van veehouders zorgde voor een ander verhaal: minder technisch en meer aandacht voor de sociale kant." 43

De overdracht van kennis aan de Provincie is minder succesvol verlopen. De opgedane kennis is vooral naar de onderzoeksinstellingen gegaan en is minder in de Provincie beklijfd. ${ }^{44}$ Een oorzaak hiervoor was wellicht dat er tijdens het scenariobouwproces weinig animo was onder de Provinciemedewerkers om gebruik te maken van de scenario's. De waan van alledag nam al snel te veel tijd in beslag om ook nog over de lange termijn na te denken. 
Ook omdat betrokken beleidsmedewerkers niet op hetzelfde beleidsgebied zijn blijven werken, is de verdere overdracht van de kennis niet helemaal naar wens verlopen. Bovendien lieten de reacties van bestuurders te wensen over: "Van Geel had waarschijnlijk graag een uitdrukkelijk reactie van PS gehad. Dat was misschien beter gelukt als de continuiteit aan de kant van de Provincie beter was gegaan. Ieder lid van het projectteam zit nu ergens anders. De onderzoeksbureaus hadden er misschien beter langer bij betrokken kunnen zijn als procesbegeleider. ${ }^{45}$ Als derde oorzaak voor de minder intense overdracht binnen de provinciale organisatie was dat het bouwproces te weinig concrete projecten opleverde waar men verder mee aan de slag kon. ${ }^{46}$

Wel heeft de aanpak met scenario's een eerste vertaling gehad in het traject op weg naar een streekplan. De Provincie heeft zich namelijk een beeld gevormd welke gebieden nu al trekken hebben van Brabant Globaal, zodat het niet meer zinvol is beleid te voeren in dit gebied gericht op 'Ons Hof'. De gebieden waar nu nog iets bestaat in termen 'Ons Hof' zijn in kaart gebracht en krijgen speciale beleidsaandacht.

Interessant is ook dat het scenario 'Ons Hof' vooral een wensbeeld schetste in de ogen van de sector, terwijl het scenario 'Brabant Globaal' vooral gezien werd als het waarschijnlijke beeld onder invloed van de internationale marktontwikkelingen. Door deze vorm van scenariobouw is de communicatieve functie ervan sterk vergroot. Zowel het onwaarschijnlijke van het wensbeeld als het onwenselijke van het waarschijnlijke beeld zijn goed over te brengen.

\subsubsection{CONCLUSIE}

Het project 'Scenario's voor landbouw en ruimtegebruik' is meer dan de meeste andere casus gericht geweest op communicatie met de samenleving, meer concreet de in Brabant belangrijke landbouwsector. De eerdere interne aanpak van het streekplan had geleid tot een conflict met de sector en GS wilde dit bij het nieuwe streekplan niet herhaald zien. De scenario's zijn mede hierdoor voor een groot deel in een interactie met actoren uit die sector tot stand gekomen. De verkenners zijn er daarbij goed in geslaagd om twee mogelijke toekomstbeelden te genereren ('Ons Hof en 'Brabant Globaal') die voor de sector herkenbaar en logisch waren.

De oriëntatie op interactie is een belangrijke karakteristiek van deze verkenning. Daar waar een groot deel van de andere verkenningen vooral tot interne interactie leidt, staat hier de interactie met de sector meer centraal. We hebben de indruk dat het wederzijdse begrip tussen actoren en het begrip voor de situatie waarin de Brabantse boerenstand zich bevindt is toegenomen dankzij de verkenning.

Het belangrijkste kritiekpunt bij deze verkenning is de moeizame verbinding ervan met de dagelijkse beleidspraktijk van Provinciale Staten en de ambtelijke diensten. 
De interne agenda en logica van deze organen en organisaties maakt het moeilijk om de aandacht voor de verkenning vast te houden. Niet helemaal duidelijk is of dit te voorkomen was geweest. Het gaat hier om de vraag hoe groot de span of attention kan zijn bij diverse partijen. We nemen in ieder geval waar in deze en de andere ex-postanalyses dat, ofwel de aandacht voor en betrokkenheid van externe partijen gering is, of dat de verkenning meer op afstand wordt gezet van het apparaat. Als gevolg daarvan (lijkt wel) de aandacht van de eigen organisatie voor de verkenningen aanzienlijk af te nemem.

Naar onze mening verdient deze meer interactieve aanpak nadere aandacht. De twee mogelijke toekomstbeelden zijn kritisch bekeken op hun haalbaarheid en voor diverse gebieden in Brabant geduid in termen van onhaalbaar, terwijl de waarschijnlijke beelden zijn bekeken in termen van hun onontkoombaarheid gezien externe krachten en de mogelijkheid om in specifieke gebieden toch te ontkomen aan deze dominante trend. Zo'n aanpak leidt in potentie tot beleidsdifferentiatie en beleidsinnovatie (mede ook door de combinatie van sectorbeleid en gebiedsgericht beleid).

\subsection{NATUURVERKENNING 1997}

\subsubsection{INLEIDING}

De opdracht voor de Natuurverkenning 1997 (NVK 97) is door het ministerie van Landbouw Natuurbeheer en Visserij, directie Natuurbeheer, verstrekt aan de Coördinatiegroep Uitvoerende Instellingen o.l.v. Dhr. Egmond, directeur Milieu van het RIVM. Aan deze coördinatiegroep werd naast het RrVM deelgenomen door het IKC-N, DLO-IBN en DLO-SC. Destijds was net besloten tot de instelling van een Natuur Planbureau functie (NPB $-f$ ) ${ }^{47}$ en de Natuurverkenning 97 zou een eerste gezamenlijk product worden. In het vervolg zou een keer in de vier jaar een NVK geleverd moeten worden.

Rapportages over de 'Toestand van de Natuur' werden al gemaakt met daarin objectieve gegevens over natuur en milieu. Maar het ministerie van LNv had ook behoefte aan een verkenning van ontwikkelingen in de toekomst op basis van huidig beleid.

De opdracht voor de Coördinatiegroep Uitvoerende Instellingen was: 'een beknopte, toegankelijke en evenwichtige presentatie bieden voor het hele beleidsveld Natuur, Bos en Landschap. Daarbij wordt geanticipeerd op de beleidscyclus van de bij de Rijksoverheid te maken / te herziene nota's, zoals Nota Waterhuishouding, NMP 3, herziening NBP.

De opdracht had drie uitgangspunten:

1 signalering van actuele situatie van natuur, bos en landschap,

2 evaluatie van effecten van beleid en 
3 verkenning van denkbare ontwikkelingen in de toekomst. 48

In de herziene wet Natuurbeheer is inmiddels vastgelegd dat de NVk een vierjaarlijkse voorbereiding voor het NatuurbeleidsPlan (NBP) is. De verkenning zou ook moeten dienen om de directie Natuurbeheer van het ministerie van LNV te prepareren op de politieke en beleidsmatige discussies in 1997 en 1998 en materiaal te leveren om beleid te vernieuwen. ${ }^{49}$

Het belangrijkste product van het traject was het document 'Natuurverkenning '97' met daarin wetenschappelijke kennis over de stand van zaken op gebied van natuur en milieu en een verkenning van toekomstige ontwikkelingen. In kader 3 is globaal de inhoud weergegeven van de verkenningen. Op basis van de verkenningen werden beleidsopgaven, de knelpunten, geformuleerd.

\section{Kader 3 Scenario's in de NVK 9750}

De basis voor het verkennende deel in de NVK 97 zijn drie scenario's uit de langetermijnverkenningen van het CPB (1997), samen met Nederland 2030, de Milieuverkenning van het RVM en de watersysteemverkenningen van het RIZA en RIKZ.

De verkenning is een hulpmiddel om een beeld te krijgen van gewenste of waarschijnlijke ontwikkelingen en kansen en bedreigingen voor natuur, bos en landschap.

Drie onderwerpen van belang voor natuur en milieu worden in de drie CPB scenario's (European Coordination, Divided Europe en Global Competition) geplaatst. De ontwikkeling van verstedelijking, landbouwwaarden en milieudruk worden op deze manier verkend. Per onderwerp (verstedelijking, landbouw en milieu) ontstaan drie nieuwe scenario's. Daarnaast is een ex-ante-evaluatie uitgevoerd op de ruimtelijke configuratie van de EHS.

\section{Verstedelfjking}

Verstedelijking heeft een aanmerkelijk effect op de leefomstandigheden voor diersoorten en op landschappelijke waarden. Het extra ruimtebeslag wordt geschat tussen de 50.000-90.000 hectare, dit verschilt per scenario. Diffuse verstedelijking heeft grotere negatieve effecten op natuur en landschap dan geconcentreerde en verspreide verstedelijkingspatronen. Bij geconcentreerde verstedelijking komt er in de stad een hoge druk op natuur en landschap te staan en hun nutsfuncties. Een beleid gericht op een beheerste spreiding van de verstedelijking biedt kansen voor natuur in de stedelijke omgeving en voor koppeling aan andere functies rondom het stedelijk gebied.

\section{Landbaww}

De druk op natuur- en landschapswaarden in agrarische landschappen neemt in de drie scenario's toe, voornamelijk door de schaalvergroting en de meer efficiënte grondbenutting. Dit heeft ook een negatief effect op de Ecologische Hoofd Structuur omdat landbouwgronden niet benut worden als verbindingszones tussen natuurgebieden.

Bij een geringe overheidsinvloed in het Global Competition scenario is de druk het grootst. In het European Coordination scenario is er meer aandacht voor natuur- en landschapswaarden. Met name voor ontwikkeling van randen en andere kleine elementen, groene dooradering, ontstaan hier kansen. 
In alle scenario's zijn er gebieden waar extensivering zal optreden en daarmee mogelijkheden voor natuur en landschap.

\section{MIIIeu}

Bij uitvoering van bestaand beleid kan het areaal verdroogde natuur met $20 \%$ worden teruggedrongen. Door een voortvarende aanpak van de verdrogingproblemen via landinrichtingsprojecten kan daar nog een $20 \%$ bijkomen. Verdrogingbestrijding vervult -in aanvulling op het ammoniak beleid - een sleutelrol in het verminderen van de milieustress in natuurgebieden. De stikstofdepositie zal dalen, maar desondanks zullen in 2020 de kritische waarden voor veel natuurdoelen worden overschreden.

\section{Ecologische Hoofdstructurur (EHS)}

Uitgaande van bestaande beleidsafspraken over de omvang van de EHS (hectares) is een analyse uitgevoerd met drie verschillende ruimtelijke varianten van de EHS: de meest waarschijnlijke EHS, een versnipperde EHS en grote eenheden EHS. De bruto begrenzing van de beleidskaart uit het Natuurbeleidsplan/SGR is als zoekgebied gehanteerd.

Uit de analyse blijkt dat t.o.v de huidige situatie een forse vooruitgang wordt geboekt in geschikt leefgebied voor de geselecteerde indicatorsoorten. De grote eenheden variant levert met dezelfde oppervlakte een toename op met ca. $40 \%$ geschikt leefgebied, t.o.v. de meest waarschijnlijke variant. De meest waarschijnlijk variant en de versnipperde variant ontlopen elkaar niet veel.

\subsubsection{DE PERCEPTIE VAN DE OPORACHTGEVER}

"Met de NPB -f en de NWK 97 moest enkenning verkregen worden voor het beleidsweld 'het beleidsueld moest emanciperen. 51

De opdrachtgevers verwachtten een gedegen wetenschappelijk onderzoek dat zij konden gebruiken bij het formuleren van nieuwe beleidsopties: "De eerste keer probeer je zo gedegen en objectief mogelijk een product te leveren." $52 \mathrm{De}$ opdrachtnemers werden daarom beperkt in de verkenningsruimte: 'In de reeks van signaleren-naar-evalueren-naar-verkennen nemen de onzekerheden en gevoeligheden toe. Exacte themakeuzen en door te rekenen scenario's zullen in de eerste fase samen met de Haagse opdrachtgever vastgesteld moeten worden.' 53

Eén van de redenen voor een voorzichtige verkenning was dat medewerkers van het ministerie 'snel bang zijn dat dingen onbeheersbaar worden en dat er nieuwe claims uitkomen voor beleid.' 54 Bovendien 'had het ongetwijfeld met politiek te maken. Er lag nadruk op realiseren van beleid dat was afgesproken, en niet zozeer op het toevoegen van nieuwe elementen. Het resultaat van de verkenningen was een beeld van wat nog gedaan moet worden om het huidige beleid te realiseren.' 55 Een andere reden die is genoemd is dat het departement "een voorzichtig departement is" en het daarom niet makkelijk koos voor een innovatieve aanpak van het verkennende deel. 56 
De opdrachtgevers verwachtten beleidsgericht onderzoek waarin geanticipeerd zou worden op de wensen van de opdrachtgevers. Op het departement van LNV heerste de mening dat de onderzoeksinstellingen over het algemeen hun onderzoek te veel lieten sturen door eigen opvattingen: "Medewerkers van onderzoeksinstellingen weten wat goed voor de natuur is. Het kost hun veel moeite om de wensen uit de samenleving en van beleidsmakers te gebruiken in hun onderzoek. Er werken vooral techneuten die geen expertise van maatschappelijke processen hebben." 57 De opdrachtgevers wilden bij de NVK 97 de onderzoeksinstellingen aansturen en "de afstand tussen de DLo instituten en het beleid verkleinen door de interactie tussen beide te verbeteren." 58

\subsubsection{PERCEPTIE VAN DE OPDRACHTMEMER}

'Het NPB vert op verzoek van het LNV onafhankelijk en wetenschappelijk betrouwbare onderzoeken en beoordelingen uit van vaagstukken op het gebied van natuurbeleid in brede zin. 59

De onderzoeksinstellingen wilden in het traject voor de Natuurverkenningen een onafhankelijk onderzoek uitvoeren: 'de NVK 97 heeft als doel om vierjaarlijks de lange termijn ontwikkeling van natuur, bos en landschap te beschrijven in afhankelijkheid van de te verwachte en mogelijke ontwikkelingen van externe omstandigheden. Daarbij zal aangegeven worden in hoeverre de gestelde beleidsdoelen bereikt kunnen worden, en voor zover dit niet het geval is, met welke middelen en maatregelen die doelen als nog dichterbij gebracht kunnen worden.' ${ }^{\circ}$ Daarnaast zagen zij de verkenningen als een vingeroefening voor de samenwerking tussen de onderzoeksinstellingen voor de NPB -f. Zij moesten hun gezamenlijke rol als Planbureau oefenen en de cultuurverschillen tussen de instellingen overbruggen: 'de samenwerking tussen de kennisinstellingen moest verbeteren en de kennis beter benut worden. De patstelling tussen de instanties moest doorbroken worden.' ${ }^{61}$ De patstelling was ontstaan doordat andere kennisinstellingen ook de NPB -f wilden krijgen die aan het RIVM was toebedeeld. 62

De opdrachtnemers wisten dat de opdrachtgevers verwachtten dat het huidige beleid als uitgangspunt diende in de verkenningen. ${ }^{63}$ De verkenningen hadden wel de speelruimte om aan te geven waar het huidig beleid nog bijgesteld moest worden om de beleidsdoelen te realiseren ${ }^{64}$ (bijv. de analyse van ruimtelijke varianten van de eHS). In de perceptie van een van de opdrachtnemers was deze opdracht niet verrassend omdat het ministerie en, opmerkelijk genoeg ook het RrVM, een klassieke sturingsfilosofie hanteerde: "Het instellen van een planbureau duidt hier op. Daarin zit een aanname over mogelijke planning en sturing (maakbaarheid) op het gebied van milieuvraagstukken." 65

Volgens de opdrachtnemers zou een innovatieve aanpak van de verkenningen een nieuwe sturingsfilosofie vereisen van het ministerie van LNV en een meer open werkwijze. "Formeel is sinds de NVK 97 al veel veranderd op het ministerie van LNV 
maar in de cultuur van het departement gaat dit langzamer. Op directieniveau wordt soms nog alleen voor de sector gewerkt" ${ }^{n 6}$

\subsubsection{DE ORGANISATIE VAN HET ONDERZOEKSTRAJECT}

"De Natuurverkenning had geen heldere start, het probleem was afbakening en het vooruitschuiven van impliciete beteidsknopen. Binnen LNV zijn in eerste instantie sectorale keuzen gemaakt. Dat kwam door de manier waarop het ministerie was georganiseerd (ook sectoraal) en hoe zij het onderzoeksveld aanstuurde ${ }^{67}$ "

Tijdens het onderzoekstraject is er met name in de begin- en eindfase interactie geweest tussen de opdrachtgever en -nemers. Overleg en afstemming heeft ook plaatsgevonden door de opdrachtgever met de interne organisatie (het ministerie). Ook hebben de opdrachtnemers onderling overleg gevoerd. Dit alles heeft echter geen buig- of knikpunten in het onderzoekstraject opgeleverd.

In de startpositie hebben de onderzoeksinstellingen een voorverkenning gemaakt die heeft geleid tot een opdrachtbrief van de opdrachtgever. In de perceptie van de opdrachtnemers was die brief vrij globaal en hebben zij verder zelf naar de vorm gezocht. Naar aanleiding daarvan hebben zij ook vragen voorgelegd aan de opdrachtgever. ${ }^{68}$ Onduidelijk was vooral op welke manier het verkennende deel van de natuurverkenningen aangepakt zou worden. In retrospectief is door zowel opdrachtgevers als opdrachtnemers aangegeven dat het wenselijk zou zijn geweest om bijvoorbeeld in de vraagformulering een breder gebied met meer partijen te betrekken, zodat de opdracht van meer organisaties komt, bijvoorbeeld maatschappelijke organisaties en belanghebbenden. ${ }^{69}$

Tussentijds is er overleg geweest tussen de directie Natuurbeheer en de andere directies van LNV, zowel op directeurenniveau als met de ambtelijke top. Dat overleg ging over de opzet, de relevante vragen, het moment van tussenrapportage, presentatie enzovoort.

De directie Natuurbeheer had moeite om collega-directeuren bij de NVK 97 te betrekken, of om een maatschappelijke en beleidsmatige discussie met andere ministerie, zoals v\&w en vROM, te organiseren. "Redenen voor die moeizame betrokkenheid waren de 'waan van de dag' en de 'overkill' aan verkenningen op dat moment. Iedere middag was er wel een workshop." $70 \mathrm{Er}$ is als onderdeel van de NVK '97 ook een publieksenquête gehouden waarin maatschappelijk draagvlak is gepeild voor de immateriële functie van natuur. ${ }^{n}$ Dit was een consultatie van het 'Nederlandse publiek' waarbij zij hun mening mochten geven over de waarde van natuur, maar dit leverde geen onverwachte wendingen voor het onderzoekstraject op. 


\subsubsection{DE ORGANISATIE VAN DE OVERDRACHT}

"Er was naumelijks een overdrachtsregeling. Pas later is bestoten om naar een nieuwe nota Natuur (NBL21) toe te werken. De venkenningen waren wel in de belekdscydus ingepland. "7

De overdracht van de kennis uit het onderzoek zou vooral via documenten moeten plaatsvinden. Vastgelegd was dat het onderzoek bij de beleidsvoorbereiding gebruikt zou worden. Hoe dit precies zou moeten gebeuren werd niet geregeld. De vraag of er beleidsopties geformuleerd zouden moeten worden aan het einde van de verkenningen werd door de opdrachtgevers als 'een hete aardappel vooruit geschoven' 73 . Achteraf is voorgesteld dat de opdrachtgever en -nemer al in een vroeg stadium samen een topdown outline van het onderzoekstraject hadden moeten maken. ${ }^{74}$ Er had een procesontwerp gemaakt moeten worden.

\subsubsection{BENUTTIHG VAN DE RESULTATEN VAN DE TOEKOMSTVERKENNING}

De benutting van de kennis is voornamelijk via documenten verlopen en was niet optimaal. Daar is een aantal oorzaken voor aan te wijzen. Er was bijvoorbeeld geen intern of extern communicatietraject over de resultaten van de NvK 97 uitgezet door de onderzoekers of de opdrachtgevers. "De beleidskant had meer met de conclusies naar buiten moeten komen." 75

Daarnaast zijn de conclusies lang intern gehouden: “De NVK 97 is zo lang mogelijk geheim gehouden waardoor de interactie met stakeholders in het Natuurbeheerveld pas laat op gang kwam. Bovendien kon het ministerie van LNV tot op het laatste moment vrijwel uitsluitend op basis van mondelinge informatie communiceren met andere departementen over de beleidsreactie die volgde op de verkenningen." 76

Bovendien was er te weinig rekening gehouden met de verkiezingen en kabinetsformatie. Door een slechte timing van de presentatie van het rapport (begin juli) ging informatie uit het rapport verloren in de organisatie. ${ }^{77}$ Uiteindelijk is de kennis uit de Nvk op drie manieren succesvol gebruikt in de beleidsvoorbereiding. Dit was vooral door de overdracht van kennis in documenten:

1 Beleidsmakers en onderzoekers Natuur zijn meer in contact gebracht met maatschappelijke ontwikkelingen: “De verkenningen hebben de gaten in beleid aangegeven en zij hebben een onderbouwing gegeven voor meer 'mensennatuur'." 78

2 De NVK heeft gezorgd voor een agendering van de grondprijsontwikkeling. Dat heeft tot gevolg gehad dat een deel van het geld van ICES (Interdepartementale Commissie Economische Structuur) ook bij Natuurbeheer terecht is gekomen.

3 De planbureaus hebben daarnaast een rol gespeeld bij het bundelen van departementale claims in het ICES -traject. 


\subsubsection{CONCLUSIES}

De opdrachtgever verwachtte een gedegen wetenschappelijk product. De verkenning diende feiten vast te stellen over ontwikkelingen in het recente verleden en over de effectiviteit van beleid. Het beleid zelf (de wilsbeschikking) mocht niet ter discussie staan en er werden geen grote innovaties verwacht. De verkenningen waren gekoppeld aan de CPB -scenario's en de oplossingsrichtingen hadden vooral het karakter van optimalisaties binnen de bestaande beleidsdoelen. Dit kwam overeen met de verwachtingen van de opdrachtnemers. De Natuurverkenning is, van de onderzochte casus, de meest klassieke in de zin van scheiding tussen willen en weten.

De Natuurverkenning 97 heeft dan ook geleid tot een wetenschappelijk rapport met kennis over de huidige stand van zaken en een voorzichtige verkenning van mogelijke ontwikkelingen.

In meer tactische zin is de verkenning wel ingezet voor interactie, maar dan met name die tussen de kennis aanleverende instituten die een planbureaufunctie voor het ministerie van LNV moesten gaan vervullen. In dat licht is de verkenning dus ook te beschouwen als een instrument voor de eigen organisatie.

Zoals bij klassiek toekomstonderzoek vaker het geval is, wordt de relatie tussen beleid en onderzoek niet uitgebreid geproblematiseerd. Het zijn min of meer eigen werelden en met behulp van een opdracht gaat er soms iets van de beleidswereld naar de verkenningswereld en met behulp van een schriftelijke document stelt de verkenningswereld inzichten in feiten beschikbaar.

Opvallend is dat tijdens het proces van verkennen de verhouding tussen de onderzoeksinstellingen en het ministerie wel ter discussie heeft gestaan, met name bij het ministerie. Zij waren van mening dat het onderzoek meer beleidsgericht moest worden uitgevoerd. $\mathrm{Zij}$ hebben in de opdrachtformulering een duidelijke rol gespeeld, vooral in het verkennende deel. Maar procesontwerpen, overdrachtregelingen en interactie zijn daarbij niet de geëigende termen geweest.

De onderzoekers die de feiten vast wilden stellen, waren niet de mening toegedaan dat deze feiten veranderden wanneer de gedachten bij beleidsmakers over de benutting van het onderzoek veranderden. Onderzoekers die de feiten willen vast leggen, achten het meestal ook niet hun taak om het beleid te vernieuwen. Mochten ze die gedachte toch ontwikkelen, dan krijgen ze van beleidsmakers al snel te horen zich daarmee niet te bemoeien. De twee domeinen overlappen nauwelijks, lijkt het.

In het verkennende deel bleek echter dat deze verhouding wel spanningen opriepen. Daarbij kon het domein van de beleidsmakers zich veroorloven om meer inhoudelijk van zich te laten horen. De scheiding tussen feiten en wensen was daar minder duidelijk te trekken. Omdat dit slechts een deel van de NVk 97 omvatte en er voor werd gekozen door de opdrachtgever en -nemers om in het verkennende 
deel voorzichtig te opereren, is de scheiding tussen de twee domeinen in tact gebleven.

Mede hierdoor hadden vooral opvallende 'feiten' van de NvK '97 impact. Beleidsmakers konden die benutten in de agendering van thema's.

\subsection{NEDERLAND 2030}

\subsubsection{INLEIDING}

'Minister de Boer heeft naar aanleiding van het nota-overleg met de vaste kamercommissie voor vRom op 3 april 1995 de kamer meegedeetd dat zij van plan is nog in haar ambtsperiode een fundamentele bezinning op de uitgangspunten en opties woor het ruimtelijk beleid op lange termijn te plegen. "79'

De directe aanleiding voor de Verkenningen Ruimtelijke Perspectieven (VRP), beter bekend onder de naam 'Nederland 2030', was de geciteerde opdracht tot bezinning. De minister heeft de Directeur-generaal van de Ruimtelijke Ordening (DGRO) de opdracht voor de voorbereiding van de VRP gegeven. Deze heeft vervolgens weer opdracht gegeven aan mensen binnen de RPD om de verkenning uit te voeren. Deze opdrachtnemers zien de DG als opdrachtgever. De verkenning bestaat uit drie delen. Eerst is een plan van aanpak opgesteld, daarna zijn toekomsten verkend en vervolgens is hierover gecommuniceerd met "de buitenwereld". Elk deel had een eigen projectleider. Een vierde deel, waarin een beleidsadvies zou worden opgesteld als antwoord op de denkbare toekomsten, en een vijfde deel, waarin communicatie met de politiek centraal stond, waren voorzien, maar zijn niet tot stand gekomen, mede door interventie van de minister.

De minister wilde met de verkenning input krijgen voor toekomstig ruimtelijke beleid en met name voor de Nota Milieu en Ruimte die in 1996 opgesteld zou moeten worden. 'Bij de begrotingsbehandeling VROM 1996 heeft de minister gesteld dat zij in 1996 een Nota Milieu en Ruimte wil opstellen. Deze dient ter voorbereiding van een omstreeks 1999 uit te brengen Nota voor de fysieke leefomgeving die in de plaats komt van een eventuele Vijfde Nota ruimtelijke ordening en het Nationaal Milieubeleidsplan.' ${ }^{80}$ Dit voorstel heeft het echter niet gehaald. Nederland 2030 is gaan dienen ter voorbereiding van de Vijfde Nota Ruimtelijke Ordening.

Op voorhand zag het onderzoekstraject er als volgt uit:

- Voorbereiding, start van het communicatietraject (intern);

- Fase 1: opstellen van definitieve vragen en eerste scenario's;

- Fase 2: opstellen en uitwerken van scenario's en eerste interne streefbeelden;

- Fase 3: opstellen en uitwerken van alternatieve streefbeelden VRP;

- Fase 4: advies aan de minister;

- Fase 5: nazorg en communicatie (behandeling door de Tweede Kamer). ${ }^{81}$ 
In de praktijk bestaat de verkenning evenwel uit drie delen:

1 Deel 1, grotendeels samenvallend met fase 1.

In 1995 publiceerde de startgroep VRP onder leiding van Dienke van der Werff (opdrachtnemer) een plan van aanpak met daarin drie aanleidingen om januari 1996 te beginnen met een verkenning van de ruimtelijke perspectieven: (1) het gevoel in brede kring dat de maatschappelijke uitgangspunten waarop de Vierde nota over de Ruimtelijke Ordening Extra (VINEX) is gebaseerd, eroderen. Dit blijkt uit de maatschappelijke discussie die o.a. in de media wordt gevoerd. (2) De fysieke bouwopgave voor de periode na 2010 lijkt te zwaar voor de vigerende beleidsconcepten, zoals compacte stad, het stadsgewest, het open-ruimte beleid en het locatiebeleid waarvan vINEX en de actualisering van VINEX uitgaan. (3) De minister wil de VRP in de zomer van 1997 uitbrengen. Dit ook al omdat in die periode de ruimtelijke ordeningsparagrafen van de programma's voor de parlementaire verkiezingen in mei 1998 geschreven worden. ${ }^{82}$

2 Deel 2: een verbinding van fase 2 en 3 met een sterk ontwerpend karakter. Onder leiding van Wouter de Jong is de verkenning tot stand gekomen. Doel was het produceren van scenario's en alternatieve streefbeelden en een agenda voor ruimtelijke beleid in de 21ste eeuw. De verkenning heeft in eerste instantie geresulteerd in 13 discussiescenario's. Deze zijn voortgekomen uit interdepartementale raadpleging. Op basis van deze discussiescenario's zijn door de projectorganisatie vier perspectieven ontwikkeld. De term perspectieven is bewust gekozen, om te voorkomen dat er een te hoog maakbaarheidsgehalte aan zou worden toegekend.

In het tweede werkdocument, ter voorbereiding van de derde fase van het onderzoekstraject wordt het doel als volgt geformuleerd: 'een basis te leggen voor vernieuwing van het nationaal ruimtelijk beleid voor de periode 20102030. Het gaat om een verkenning van uitgangspunten en opties voor ruimtelijk beleid. ${ }^{83}$ ' Het beoogd resultaat is een perspectievennota 'Nederland 2030'. Uiteindelijk is NL 2030 evenwel geresulteerd in een politieke keuze voor een van de scenario's (Nederland Stedenland+), op basis waarvan vervolgens de nota Ruimte van Nederland is gemaakt (de uiteindelijke titel van wat in het regeerakkoord nog de houtskoolschets heette).

3 Deel 3: Communicatie over de perspectieven, wooraf eigenlijk niet expliciet geagendeerd.

De discussienota met de vier perspectieven (zie kader 4) vormt een belangrijk tussentijds product in de verkenning. Op basis daarvan zijn diverse interacties met experts en bestuurders georganiseerd. Dit heeft weer geresulteerd in het debatverslag(Nederland 2030 - debat, met bijlagen, 1998). Door deze debatronde is met name aandacht ontstaan voor de verschillen tussen landsdelen. Dit aspect is ook bij de aanpak van de vijfde nota ruimtelijke ordening een belangrijke rol gaan spelen. 


\section{Kader 4 De Perspectleven van Nederland 2030 In vogelvlucht. 84}

\section{Palet}

Burgers en bedrijven maken hun eigen leefomgeving. Er is vestigingsvrijheid en een strijd om ruimte. Overheden staan tussen maatschappelijke partijen en doen investeringen meer in de vorm van medefinanciering van door private actoren genomen initiatieven.

Er is in Palet een extra ruimteclaim voor het wonen. Daarbij is vooral vraag naar grootstedelijke centrummilieus met een grote dichtheid, en suburbane en buitenstedelijke milieus met een lage dichtheid.

Automobiliteit van personen zal sterk toenemen door de welvaart, bevolkingsgroei en door toename aan diversiteit van leefstijlen en de ruime keuzemogelijkheid voor wonen en werken.

De economische ontwikkeling wordt gekenmerkt door een relatief snelle omschakeling naar kennisen kapitaalintensieve productiesegmenten en de dienstensector.

Het ruimtelijk beeld is een resultaat van het voortdurend onderhandelingsproces tussen marktpartijen. Palet levert een kleurrijk ruimtelijk perspectief op waarin verscheidenheid een sleutelbegrip is.

\section{Parklandschap}

$\mathrm{Er}$ is in Parklandschap een harmonie tussen mens en natuur als cultuuropgave. Er is een verweving van stad en land en versterking van de identiteit van het cultuurlandschap wordt nagestreefd door de centrale overheid. Het Rijk richt zich op stimuleren, inspireren en innoveren vooral vanuit een netwerksturing met instrumenten gericht op maatwerk, onderhandeling en beinvloeding van de netwerkstructuur. Bestuurlijk speelt de Provincie een sleutelrol.

In parklandschap zullen de woondichtheden variëren. Dit leidt tot uitwaaiering in vooral stedenregio's en de intermediaire gebieden. In de woonvoorkeuren zijn mogelijkheden tot combineren van wonen en werken of wonen en recreatie belangrijk.

De mobiliteit van personen en goederen neemt toe en daarbij is er een sterke voorkeur voor individuele vervoerswijzen.

Dragers van de economie zijn hoogwaardige kennis- en kapitaalintensieve sectoren in industrie en dienstverlening, de internationale transport- en distributieactiviteiten, en hoogwaardige land-en tuinbouw. Regio's hebben een eigen kleur en een sterke identiteit. Parklandschap levert een dynamisch landschap dat nooit af is.

\section{Stromenland}

In Stromenland is er een dynamisch partnerschap tussen economie en ecologie. De stromen van verkeer en water zijn de ordende principes. De verkeersstromen van auto, trein en schip worden zoveel mogelijk bij elkaar gebracht. Vervoersassen fungeren als dragers voor nieuwe woon- en werkgebieden. Inrichting op basis van verkeer en water leidt tot een voorkeur voor verstedelijking in de vorm van een kralensnoer langs de vervoersassen. Er ontstaan vooral middelgrote steden en groene gebieden en verbindingszones voor natuur en recreatie worden vrijgehouden.

De overheid neemt het voortouw bij grote projecten zonder dirigistisch of betuttelend te zijn. Er is een duurzame economische ontwikkeling die betrekking heeft op de groei van de werkgelegenheid en op de emissie en kwaliteit van gebieden. 


\section{Stedenland}

In Stedenland wordt door een versterking van het contrast tussen bebouwing en open ruimte de kwaliteit van de stad en het landelijk gebied op een hoger peil gebracht. Bestaande steden kunnen beter en efficiënter gebruikt worden in een onderlinge concurrentie. Het landelijk gebied wordt opener.

Concentratie van wonen, werken en voorzieningen in steden leidt tot een beperkte toename van de mobiliteitsgroei en tot kortere verplaatsingsafstanden.

De centrale overheid schept voorwaarden voor regionale en lokale overheden met een actief stimuleringsbeleid voor herstructurering en zuinig ruimtegebruik. Voor realisering is inzet van marktpartijen, maatschappelijke instellingen en burgers onmisbaar. Publiek Private Samenwerking krijgen vorm in bestuursovereenkomsten of 'pacten'.

De stuwende kracht van de stedelijke economie wordt gevormd door kennisintensieve bedrijvigheid en dienstverlenende sectoren.

Op nationale schaal ontwikkelt zich een netwerk van een beperkt aantal stedelijke knooppunten.

\subsubsection{DE PERCEPTIE VAN DE OPDRACHTGEVER}

De minister heeft de Directeur-generaal van de Ruimtelijke Ordening (DgRO) de opdracht voor de voorbereiding van de VRP gegeven. De minister zou regelmatig geïnformeerd worden door de dgRO, de gedelegeerd opdrachtgever, en het uitvoerende projectteam.

In het plan van aanpak is schriftelijk vastgelegd dat: "De minister is eindverantwoordelijk voor de start en de beëindiging van de VRP. De DGRO stelt op ijkmomenten de VRP producten vast en wordt regelmatig geïnformeerd. dROP is gedelegeerd opdrachtgever waarmee wekelijks contact wordt onderhouden, commitment van het DT wanneer de DSP meebeslist in het DT (dus een DT +), commitment van de minister wordt gezocht in regelmatige besprekingen." 85 Minister De Boer en de gedelegeerd opdrachtgever gaven de (verschillende) opdrachtnemers van de verkenning Nederland 2030 in aanvang aanzienlijke handelingsruimte. De opdrachtnemers deden onderzoek naar toekomstbeelden die niet strookten met bestaand beleid. De Boer had vooral behoefte aan inzicht in maatschappelijke ontwikkelingen die relevant waren voor de grote nota's van VROM.

Toen er echter drie denkbare toekomsten aan haar werden gepresenteerd heeft zij verzocht om een vierde toe te voegen met daarin een uitwerking van het huidige beleid. Op dat moment perkte zij de ruimte van de verkenners in. Zij wilde niet met vier denkbare beelden naar buiten treden zonder haar politieke voorkeur voor een van deze beelden uit te spreken "Van een minister mag je verwachten dat die een mening heeft." 86 Als gevolg hiervan werden de door de opdrachtnemers als denkbare toekomsten ontworpen perspectieven vanaf dat moment door vrijwel alle actoren in de sector beoordeeld als zou het gaan om meer of minder gewenste toekomsten. 


\subsubsection{PERCEPTIE VAN DE OPDRACHTNEMER}

De opdrachtnemer van de verkenning zelf was het projectteam NL 2030 onder leiding van projectleider Wouter de Jong. Dit projectteam ging van start per 1 januari '96. Daaraan voorafgaande heeft de startgroep VRP gefunctioneerd onder leiding van Dienke van der Werff (van september tot december '96). Deze startgroep heeft het eerste plan van aanpak opgesteld. In deze fase was er nog discussie over wie de opdrachtnemer zou worden (interdepartementaal of ten minste departementaal), maar uiteindelijk is gekozen voor een opdracht uitsluitend aan de RPD. Deze dienst had, historisch gezien, de ruimtelijke verkenningen onder zijn hoede.

De startgroep VRP formuleerde twee primaire doelen voor het onderzoekstraject: "de juiste vragen ${ }^{87}$ voor het toekomstig ruimtelijk beleid formuleren en verzamelen vanuit de samenleving, met inbegrip van de vakwereld, bestuurders en politici. Door deze vragen te onderbouwen en met elkaar te confronteren wordt de agenda voor het ruimtelijk beleid voor de $21^{e}$ eeuw bepaald." ${ }^{88}$ Het tweede doel dat de opdrachtnemer zich stelde in het plan van aanpak was: "samenhangende antwoorden zoeken en streefbeelden samenstellen met behulp waarvan discussie over de beleidsvernieuwing mogelijk wordt." ${ }^{89}$ De constructie van een gezamenlijke toekomst door relevante actoren, waaronder onderzoekers en beleidsmakers, was dus het uitgangspunt. ${ }^{90}$ In deel twee is hieraan verder invulling gegeven door maatschappelijke en ruimtelijke ontwikkelingen te combineren tot een viertal perspectieven (in plaats van de term streefbeelden, die eerder was gebruikt). De nadruk lag hier - in de ogen van de opdrachtnemers - op mogelijke toekomsten, maar gecombineerd met elementen van wensbeeld en waarschijnlijkheid.

In retrospectief constateren enkele van de opdrachtnemers dat het wenselijke, mogelijke en waarschijnlijke door elkaar heen zijn gaan lopen. Dit kwam volgens hen mede omdat zijzelf enerzijds verkenner waren en anderzijds beleidsmakers waren: "De menging van wens, mogelijk en denkbaar is tamelijk onbewust gebeurd en heeft mede daardoor verwarring veroorzaakt." 91

\subsubsection{DE ORGANISATIE VAN HET ONDERZOEKSTRAJECT}

Deel één van het traject is gestart met een uitgewerkt procesontwerp, waarin alle ruimte is gelaten gaandeweg aanpassingen te plegen. De opdrachtnemers zetten een relatief open werkproces in met een 'cyclische karakteristiek: waarin resultaten worden gebruikt om het vervolg te definiëren. De VRP-groep geeft daarbij steeds de nieuwe impuls voor de volgende cyclus waarin de omgeving in wisselende mate zal participeren. Analyse, doelontwikkeling, uitwerking en acceptatie zullen elkaar een aantal malen opvolgen.' De twee opvolgende delen van het traject zijn meer gaandeweg tot ontwikkeling gekomen. 
De opdrachtnemers zochten interne en externe commitment voor het project en de thema's die aan de orde zouden moeten komen. Daarvoor zijn interviews gehouden met sleutelfiguren binnen de RPD en is een aantal externe deskundigen op persoonlijke titel benaderd. Het PvA was voorwerp van intern overleg en besluitvorming. 92

\section{Buigpunten}

In het proces zijn diverse buigpunten te onderscheiden. We besteden aandacht aan vijf belangrijke. Na de afronding van de startfase heeft een eerste bijstelling plaats gevonden. Omdat het besluit was gevallen dat de RPD de opdrachtnemer zou zijn, is niet alleen het ruimtelijke karakter van de verkenning versterkt, ook zijn de principes van de vier scenario's, waarmee later met de buitenwereld is gecommuniceerd, intern binnen de RPD vastgesteld. Wel is de uitwerking in interactie met andere departementen gegaan.

De wens van de minister om een vierde streefbeeld aan de drie toe te voegen, is als een tweede buigpunt te beschouwen, hoewel de consequenties ervan pas later duidelijk werden. De minister miste de lijn van het huidige beleid. Voor haar was dat een belangrijk politiek standpunt. Ze kon, met andere woorden, niet goed uit de voeten met een verkenning waarin de eigen wensbeelden niet centraal stonden.

Een derde buigpunt is waar te nemen door de komst van deel 3, de communicatie met de vakwereld, maatschappelijke organisaties en bestuurders (in de regio). We zien hier interessante aanzetten om te komen tot een meer interactieve vorm van toekomstverkenning. De vier scenario's waren in de ogen van de opdrachtnemers hulpmiddelen om een gezamenlijk debat op te zetten op weg naar meer gedeelde toekomstbeelden. Deze ambitie van de opdrachtnemers is niet helemaal bevredigd. Het bleek moeilijk om in de gesprekken in de regio los te komen van de dagelijkse beleidsthema's die spelen tussen regionale bestuurders en de minister / het ministerie. Voor een deel gold dit ook voor de professionele debatten. Daarbij moet in ogenschouw worden genomen dat in de debatten overwegend door ruimtelijke ordenaars is gesproken.

Het vierde buigpunt, dat al lag besloten in het tweede, voltrok zich toen de minister de voorkeur uitsprak voor het perspectief stedenland, dat in termen van wensbeeld het dichtste aanlag tegen het bestaande beleid. Tot dan toe waren de beelden ingezet als denkbare toekomstbeelden die een instrument waren om de wenselijke toekomst in beeld te krijgen. Doordat de minister haar voorkeur uitsprak werden de denkbare toekomstbeelden automatisch geinterpreteerd door andere actoren als wensbeelden. Hierdoor veranderde de discussie inhoudelijk. Ook werd hierdoor de politieke ruimte in de discussie klein omdat de minister een politieke standpunt innam. ${ }^{93} \mathrm{Zij}$ verzette zich hiermee tegen de "no-nonsense manier waarop met ruimtelijke ontwikkeling werd omgegaan." Bovendien voelde zij zich min of meer verplicht om met een visie naar buiten te treden omdat, "de roep daarom vanuit de tweede kamer en de media groot was." ${ }^{94}$ De verkenners hebben 
het doel van de scenario's daarop aangepast, dit werd: 'Verkrijgen van feedback over de persoonlijke inzet van de minister'. ${ }^{95}$

Een laatste buigpunt, dat vooral de kennisoverdracht van Nederland 2030 naar het beleid heeft bemoeilijkt, waren de verkiezingen in 1998. Nederland 2030 was bijna klaar toen de kamerverkiezingen voor de deur stonden. Hierdoor hebben 'de minister en de projectorganisatie terughoudend geopereerd en zijn zij niet meer toegekomen aan een beleidsadvies'. ${ }^{96}$ Een nieuwe minister trad aan die niet betrokken was geweest bij het onderzoekstraject: “De nieuwe minister had het onderzoekstraject voor Nederland 2030 niet meegemaakt. Het is wel aan hem gepresenteerd maar hij heeft het zich niet echt eigen gemaakt." 97

\subsubsection{DE ORGANISATIE VAN DE OVERDRACHT}

'De VRP is geen vrijblijvende oefening. De RPD zal als actviseur van de minister stelling nemen vanuit haar beleidsverantwoordelijkheid voor een duurzame en hoogwaardige ruimtellike inrichting van Nederland. Pas na een vakmatig, maatschappelijk en uiteindelijk politiek debat kan deze discussie worden afgerond'. 9s

Een constante overdracht van kennis is nagestreefd, waarbij de RPD zowel zender als ontvanger zou zijn. 'Doel van de communicatie is het uitwisselen van informatie (zenden en ontvangen) en het bevorderen van voorwaarden voor het ontstaan van draagvlak.' 99 De uitwisseling van kennis met externe actoren zou moeten gaan over de inhoud van de scenario's en streefbeelden, en over het verloop van het proces.

'De interne communicatie met medewerkers van de gehele RPD, respectievelijk VROM, was gericht op het vergroten van kennis en betrokkenheid.' ${ }^{100}$ Deze overdracht is in een communicatieplan vastgelegd. Bovendien is vastgelegd dat een aantal producten afgeleverd zou worden aan de minister en de gedelegeerd opdrachtgever. De opdrachtnemers veronderstelden dat de eigen organisatie als initiatiefnemer ook wel gebruik zou maken van de resultaten. ${ }^{101}$

\subsubsection{BENUTTIMG VAN DE RESULTATEN VAN DE TOEKOMSTVERKENNING}

"Doordat Nederland 2030 van nature aan de afdeling thematische planvorming toekwam, leefde het project niet echt bij de rest van de medewenkers die vooral bezig waren met de VINEX AC. NL 2030 was een beetje een speeltuin en werd niet zo serieus genomen. Daardoor heeft het intern ook niet echt wortel geschoten." 102

Nederland 2030 heeft een groot aantal kennisproducten opgeleverd. Deze zijn breed verspreid en op diverse plekken benut voor eigen debatten en verkenningen, alsmede voor onderbouwing van de eigen inbreng in volgende beleidsprocessen, met name de voorbereiding van de Vijfde Nota Ruimtelijke Ordening. Daarnaast is Nederland 2030 benut om het Stedenland-plus advies te formuleren. Dat advies is 
later in het regeerakkoord opgenomen. Dit advies kwam niet rechtstreeks uit de discussies van NL 2030 voort, maar is gemaakt door de VROM -raad. ${ }^{103}$ De drie formateurs hebben dat advies gebruikt als regeringsstandpunt. Een laatste belangrijke benutting was dat de rondgang door het land de 'geesten rijp' heeft gemaakt. Dit bleek bij de landsdelige overleggen die voor de Vijfde nota zijn gevoerd. Overigens is dit niet alleen door Nederland 2030 mar ook door de discussies van Het Metropolitane Debat gebeurd. 104

De benutting van de verkenning binnen het eigen departement is minder eenduidig aan te geven. Het gebruik lijkt gering. Bij de voorbereiding van de Vijfde nota, wordt "opvallend veel opnieuw gedaan, net even anders dan in Nederland 2030." 105 “De overdracht aan de makers van de Vijfde Nota Ruimtelijke Ordening is problematisch, onder andere omdat de 'kennis in hoofden' uit de organisatie verdwijnt als mensen vertrekken. Soms nemen zij ook hun boekenkast mee." 106

\subsubsection{CONCLUSIE}

Het verkenningstraject Nederland 2030 heeft onmiskenbaar invloed gehad op beleidsprocessen. Nog steeds wordt gesproken over het scenario stedenland en over benutting van kennis uit het scenario stromenland. De start van de verkenning kan worden gevonden in uitspraken van de toenmalige minister van VROM. Anderzijds kan ook worden gezegd dat de verkenning een 'normaal' onderdeel vormt van het cyclische proces van nationale plannenmakerij op het nationale niveau. Het was gewoon weer eens tijd voor een verkenning, zei een van de geïnterviewden.

In het eerste deel van Nederland 2030 is expliciete aandacht besteed aan het proces van verkennen als zodanig. Daarna ging verliepen de verkenningen overwegend 'gaande weg'. Gedurende de eerste ronde wordt duidelijk dat de ambitie van de minister om een geïntegreerde nota voor ruimte en milieu politiek niet haalbaar is. Nederland 2030 is vooral een product van de RPD geworden en vooral in de ruimtelijke ordeningswereld besproken. De inperking (tot uitsluitend ruimtelijke ordening) en buiging in het proces (naar wensbeelden die al lang bestonden in de betreffende beleidswereld) heeft zijn definitieve vorm gekregen door de keuze van de minister voor Stedenland. Daarmee verdween de ruimte om toekomsten te verkennen die niet in dit wensbeeld zouden passen. Een belangrijke kritische meerwaarde van de verkenning bleef hierdoor onbenut: het beantwoorden van de vraag wat de overheid zou moeten doen in geval er ontwikkelingen optreden die van dat wensbeeld afwijken, dit was wel uitdrukkelijk nagestreefd door de verkenners. Door de uitspraak van de minister zijn de verkenners ook niet meer toegekomen aan de vraag welk beleid ontworpen kan worden indien de samenleving zich toch blijkt te ontwikkelen conform palet, parklandschap of stromenland. Verder blijkt de overdracht van kennis en leerervaringen met name via personen te verlopen. En op dat punt doet zich een opvallend fenomeen voor, dat 
we ook in andere casus kunnen waarnemen, namelijk dat de meeste direct betrokkenen van de verkenning Nederland 2030 na afronding van dit traject, niet meer een centrale rol spelen in de totstandkoming van de vijfde nota. De komst van de nieuwe minister is daarbij cruciaal, maar ook het vertrek van betreffende ambtenaren naar andere posities. Mede daardoor is er in het traject van de vijfde nota veel nieuw onderzoek verricht.

\subsection{WOONVERKENNINGEN MMXXX}

\subsubsection{INLEIDING}

"De aankeiding voor de verkenningen was de tradibe van VRom on ruimtelijke verkenningen uit te brengen. DG Kokthuis kwam met de vraag on dit ook te doen op gebied van de volkshuisvesting. "1or

De Woonverkenningen zijn van start gegaan in 1996 met als opdrachtgever de Directeur-generaal van de Volkshuisvesting mr. L.H.J. Kokhuis en gedelegeerd opdrachtgever de directeur Financiën, Strategie \& Control, drs. ing. A.H.J. Moerkamp. De opdrachtnemer was een projectgroep van het directoraat generaal Volkshuisvesting (DGVH) met als projectleider drs. ing. A.A.J. Rutjens. Aan de projectgroep werd door mensen van de DGVH, DGM, Rijks Planologische Dienst (RPD) en de DVEB deelgenomen. De verkenningen hadden tot doel: 'De toekomst van het wonen te verkennen, evenals de keuzen die daarbij gemaakt kunnen worden. Zij geven tegelijkertijd een aanzet voor het maatschappelijk debat. ${ }^{108 *}$

De verkenningen zijn gebaseerd op de CPB scenario's, een woonbehoefte onderzoek, een aantal achtergrondstudies en publieke discussies. Vijftien externe onderzoeksbureaus hebben bijgedragen, tien essayisten en een aantal schoolkinderen. ${ }^{109}$ "De woonverkenningen onderzoeken de toekomstige mogelijkheden aan de hand van economische en sociaal-culturele verkenningen." 110.

Op basis van deze gegevens zijn de volgende producten geleverd:

- drie decors voor volkshuisvesting (zie kader 5),

- negen discussiesscenario's, drie per thema: 'duurzame woonmilieus', Teven in de stad' en 'corporaties in 2030'.

De decors zijn gebruikt om ontwikkelingen per woontypologie te schetsen in de Woonverkenningen MMxxx. In datzelfde document worden robuuste veranderingsopgaven geformuleerd. Tot slot wordt de agenda voor de toekomst van de volkshuisvesting gegeven. ${ }^{111}$ De Woonverkenningen MMxxx komen uit hetzelfde familienest als Nederland 2030, de Verkenning Ruimtelijke Perspectieven van de RPD. Op 1 juli 1997 zijn deze documenten samen aan bewindslieden van het ministerie van VROM aangeboden. 


\section{Kader 5 De centrale vraagstukken en decors voor 2030112}

De centrale vraagstukken in de Woonverkenning zijn: wat zijn de gevolgen van een verschuiving van de aandacht van de kwaliteit van de woning naar de kwaliteit van het woonmilieu, bijvoorbeeld voor de doelgroepindeling? Vraagstukken met betrekking tot de duurzaamheid van woonmilieus in functionele, sociale en ruimtelijk-ecologische zin. De kansen van de stad tegen de achtergrond van zich ontwikkelende woonvoorkeuren en mogelijke ruimtelijke perspectieven. Tot slot, hoe zullen alle ontwikkelingen de volkshuisvestingsagenda bepalen en wat is de rol van de overheid en corporaties daarbij? ${ }^{113}$

De CPB scenario's zijn gekozen als het decor waarbinnen het toekomstige handelen van de woonconsument zich afspeelt. Dit zijn macro-economische ontwikkelingen in onderlinge samenhang. De behoeftepatronen van consumenten zijn op andere manieren berekend dan door het CPB gedaan was. De decors voor de woonverkenningen zijn:

\section{Verdeeldheid}

De bevolkingsgroei is in dit scenario 50\% lager dan nu. De bevolking loopt op tot 16,2 miljoen in 2020 en dan terug tot circa 16 miljoen in 2030. Het aantal huishoudens groeit met 1,2 miljoen. Ongeveer een kwart van de bevolking bestaat uit ouderen. De groei van de werkgelegenheid is beperkt en concentreert zich in de tertiaire en quartaire sector. Er zijn geen grote veranderingen wat betreft leefstijlen en consumptiepatronen. De invloed van de verzorgingsstaat neemt af. Er is ook minder bereidheid om maatschappelijke solidariteit op te brengen.

\section{Coordinatle}

In dit scenario groeit de bevolking het sterkst tot 18,5 miljoen personen. Het aantal huishoudens groeit naar circa 8,2 miljoen. In dit scenario is er meer aandacht voor immateriële leefstijlen en solidariteit dan in Verdeeldheid. Ook is er meer aandacht voor collectieve ruimten en openbare voorzieningen. Buurtbeheer en aandacht voor ecologische kwaliteiten van de woonmilieus zijn hier kansrijk.

\section{Compettie}

In dit scenario groeit de bevolking naar 17,1 miljoen. Het aantal huishoudens is door individualisering groot en stijgt naar 8,4 miljoen. In dit scenario wordt haast volledige werkgelegenheid gerealiseerd. De groep met een laag inkomen en een kleine keuzeruimte is klein maar de tegenstellingen zijn scherp. Er zullen scherpe lijnen tussen woonmilieus ontstaan.

\subsubsection{DE PERCEPTIE VAN DE OPDRACHTGEVER}

De formele opdracht kwam van de DGvH. Dhr. Kokhuis. Hij was de bestuurlijke initiatiefnemer en Dhr. Tommel was formeel de politiek opdrachtgever. Dhr. Moerkamp was gedelegeerd opdrachtgever die deelnam aan de projectgroep. Een aanleiding voor de verkenningen was voor de opdrachtgevers de veranderde sturingsfilosofie van het ministerie van VROM. In de Nota Heerma (1989) was de aanzet gegeven voor de verzelfstandiging van de actoren in het veld: “Het centrale sturingsidee was al door elkaar geschud, onder andere in de Nota Heerma. In de 
verkenningen zou hierover verder nagedacht kunnen worden". ${ }^{114}$ Het overheersende idee bij de opdrachtgevers en de ambtenaren van VROM was dat de verzelfstandiging van de sector verder doorgevoerd moest worden. De staatssecretaris wilde echter indertijd de gevolgen van de vergaande verzelfstandiging overdenken voordat een onomkeerbaar proces in gang zou worden gezet: "als het kind het huis uit is, dan komt het zeker niet meer terug." ${ }^{115}$ Een minderheid binnen het ministerie van VROM was van mening dat op basis van de verkenningen ideeën geformuleerd moesten worden door het ministerie over de verzelfstandiging van de beleidssector. Het ministerie moest net als de andere actoren uit het beleidsveld over de toekomst nadenken omdat: 'Het ministerie de onvermijdelijke vraag kon verwachten vanuit het veld om meer verzelfstandiging. De actoren en de overheid moesten ideeën naast en met elkaar ontwikkelen tijdens de verkenningen.' 116

Uiteindelijk kregen de verkenningen twee doelen voor de opdrachtgevers:

1 onderzoek doen op gebieden waarvan er niet genoeg kennis was binnen het ministerie: 'Het is belangrijk om te zorgen dat er geen schijnkennis aanwezig is.' 117

2 een onbevooroordeelde discussie voeren met het veld.

De opdrachtgevers wilden kennis verkrijgen over de mogelijke gevolgen van een verdere verzelfstandiging van de sector. Hierbij waren volgens de opdrachtgever de trendanalyses niet meer zo interessant omdat die Tijnen alleen op basis van huidig beleid doorgetrokken kunnen worden. Vaak worden ook oude parameters gebruikt en wordt er bijvoorbeeld niet naar de doelgroep gekeken bij woonwensen.' ${ }^{118} \mathrm{Zij}$ percipieerden de toekomstige ontwikkelingen niet meer als een lineaire ontwikkeling, vanuit het heden doorberedeneerd naar de toekomst. In het denken over de toekomst door het ministerie moest ruimte komen voor wenselijkheden en mogelijkheden die met het huidige beleid niet denkbaar zouden zijn. Daarnaast moesten de verkenningen kennis verzamelen over het beeld dat actoren hebben over mogelijkheden en wensen, en moest de interactie met het beleidsveld opgezocht worden om "de deskundigheid en de denkkracht die daar zijn te benutten en een open gedachtewisseling aan te gaan." 119

Door in een interactie met de beleidssector kennis te verzamelen werd commitment gecreëerd bij de actoren. De opdrachtgevers verwachtten dat zij zich minder 'vrijblijvend' zouden opstellen. “Het was een manier om gezamenlijkheid te vinden in een heldere probleemdefiniëring over bijvoorbeeld de doelgroep en financiering. Door het verkennende onderzoek ontstond consensus in een interactie over die definiëring van het probleem; niet over wenselijke oplossingen!" 120 Om deze doelen zo goed mogelijk te kunnen bereiken achtten de opdrachtgevers het noodzakelijk een ambtelijke opdracht te verstrekken zodat de wenselijkheden vanuit de politiek niet zouden interfereren met het onderzoek naar trends en wenselijkheden. De politiek verantwoordelijke gaf veel ruimte om een beleidsinnovatie tot stand te brengen. “De Woonverkenningen waren geen politiek stuk maar hebben opzettelijk een ambtelijke opdracht gekregen zodat veel ruimte zou ontstaan om het onderzoek in te doen." 21 
De opdrachtgever was zich er dus van bewust dat innovatief onderzoek een bedreiging kan zijn voor bestaand beleid. Zij wilden zorgen dat het onderzoek "serieus genomen werd door ambtenaren op het ministerie, maar ook door de onderzoekers zelf." 122

\subsubsection{PERCEPTIE VAN DE OPDRACHTNEMER}

"De projectleiding was een soort evenurictitskunstenaar die een aantal bonden draaiende moest houden op stakjes".123

In tegenstelling tot de opdrachtgevers nemen de opdrachtnemers aan dat de sturingsfilosofie veranderd is. Het projectteam had drie procesdoelen voor de verkenningen geformuleerd waaruit dit blijkt:

1 herpositionering van DGVH;

2 sturingsfilosofie;

3 ander manier van omgaan met het veld.

De verkenningen nemen de veranderde sturingsfilosofie als uitgangspunt en bouwen er op voort. Die filosofie staat niet meer ter discussie. ${ }^{124}$ Volgens de opdrachtnemers moest het proces van de Woonverkenningen argumenten voor politieke keuzen opleveren. Het onderzoek verkende de mogelijkheden in de toekomst, die worden bepaald door de wensen en de feiten. Bovendien moesten de wensen van actoren in het veld afgestemd worden met die van het ministerie.

De projectgroep stelde zich ten doel om een verkenning naar een mogelijke toekomst uit te voeren. Daarbij moesten actoren uit het beleidsveld de ruimte krijgen om hun wensen kenbaar te maken. Die wensbeelden waren de voorwaarden voor mogelijke toekomstige ontwikkelingen waaruit de minister keuzen zou kunnen maken.

De opdrachtnemer was dus van mening dat de waarschijnlijke ontwikkelingen en de wensen van actoren mede bepaalden wat de mogelijkheden waren: "Het 'mogelijke' wordt afgebakend door wat wenselijk wordt gevonden door het de actoren in het veld. Dat is niet op alle beleidsterreinen zo." 125

In retrospectief zijn de opdrachtnemers van mening dat zij de Woonverkenningen zo veel ruimte konden geven in de verkenningstocht naar de mogelijke toekomst omdat de aansturing van DGVH minder topdown was en minder afhankelijk van bijvoorbeeld de politieke voorkeur van de minister dan bijvoorbeeld DGM en RPD: "Dit blijkt onder andere uit het proces van Nederland 2030 waarin de Boer een voorkeur uitsprak voor een van de scenario's." 126

\subsubsection{DE ORGANISATIE VAN HET ONDERZOEKSTRNECT}

Tijdens het onderzoekstraject is er veelvuldig interactie geweest tussen de opdrachtgever en opdrachtnemer. In de kerngroep die het proces uitstippelde, 
zaten bijvoorbeeld de gedelegeerd opdrachtgever en de opdrachtnemer samen. De buigpunten tijdens het onderzoekstraject deden zich voor naar aanleiding van interacties tussen opdrachtgever en -nemer, of met andere actoren uit de sector. De regie van de verkenningen is door de gedelegeerd opdrachtgever en de opdrachtnemer samen gevoerd. In een nauwe persoonlijke interactie is de procesarchitectuur bedacht: "De regie van de Woonverkenningen is binnenskamers uitgedacht door met name Dhr. Moerkamp en Dhr. Rutjens. Het project is in heel korte tijd klaargestoomd." 127

De opdrachtgever heeft vooral in het begin en aan het einde van het verkenningenproces inhoudelijk kunnen sturen. Daarbij werd aangegeven welke relevante vragen nog moesten worden opgenomen in de verkenningen, dit waren onder andere verzelfstandiging, sturing en toezicht. ${ }^{128}$ Ook de opdrachtnemer en actoren uit het beleidsveld kregen ruimte om thema's aan te dragen die verkend moesten worden. Een gevolg hiervan was dat "beleidsactoren al tot een doelvervlechting kwamen in de voorbereidende fase van het beleidsproces." 129 Ook tussentijds heeft de ambtelijke opdrachtgever concepten van de Woonverkenningen onder ogen gekregen en is daarbij nagegaan of de verkenningen 'antwoord gaf op relevante vragen'. 130

De inventarisatie van wenselijkheden ging van start in december 1996 en januari 1997 in een gespreksronde. Dit was een eerste verkenning naar de toekomstverwachtingen en -visies van gemeenten, corporaties en marktpartijen. Research voor Beleid uit Leiden heeft deze omgevingsscan gemaakt op basis van gesprekken met 39 sleutelactoren. De resultaten zijn samengevat in het rapport 'Gesprekken in het veld'.

Er is ook overleg geweest met onder andere de RPD om af te stemmen over de termijn van de vooruitblik. Over het algemeen zijn de twee processen los van elkaar verlopen. In de woonverkenningen is gebruik gemaakt van de wensbeelden, de perspectieven, uit Nederland 2030 en de trendanalyses van de woonverkenningen zijn gebruikt in Nederland 2030.

In maart 1997 hebben zes workshops plaatsgevonden, ook wel themadebatten genoemd. Daaraan namen diverse vertegenwoordigers van maatschappelijke organisaties op gebied van de volkshuisvesting en aanpalende deelterreinen deel. “De actoren mochten praten over sociale consequenties, politieke legitimatie van bepaalde beleidsopties". 131

Het traject van fact finding ging ook eind 1996, begin 1997 van start. De achtergrondstudies en basisverkenningen werden gemaakt en zouden als input voor de workshops in maart gebruikt worden.

De achtergrondstudies zijn tijdens de integratiedagen door verschillende onderzoeksinstellingen bij elkaar gebracht. Ook de onderzoeken naar wensbeelden zijn hierbij gevoegd. De resultaten van onderzoeken naar het 'mogelijke' en 'wenselijke' werden dus bewust vervlochten.

Volgens de projectgroep was dit nodig mede omdat deelnemers uit het veld het overzicht kwijt raakten: “Omdat het overzicht zoek was bij de actoren zijn op een 
gegeven moment de onderzoekers bij elkaar gezet om de gegevens te bundelen: de integratiedagen." ${ }^{132}$ Misschien is dit een buigpunt geweest in het onderzoekstraject. Het lijkt erop dat dit naar aanleiding van interventie van deelnemers is bedacht door de projectgroep, maar met zekerheid is dat hier niet vast te stellen.

\subsubsection{DE ORGANISATIE VAN DE OVERDRACHT}

In de procesarchitectuur is vooral aandacht besteed aan de kennis die verzameld moest worden. De overdracht van die kennis is niet formeel geregeld. De projectgroep wilde 'kennis in documenten' overdragen aan actoren uit het beleidsveld en aan de politiek, en zij wilde 'kennis in hoofden' van actoren overdragen aan de beleidsmakers.

De interactie met actoren was een manier om gezamenlijkheid te vinden in een heldere probleemdefiniëring over de doelgroep en financiering van het volkshuisvestingsbeleid. De synergie moest nieuwe kennis in hoofden opleveren: "Door het verkennende onderzoek ontstond consensus in een interactie over die definiëring van het probleem; niet over wenselijke oplossingen." 133 Bovendien moest de impact van de woonverkenningen er meteen zijn. "De deelnemers aan discussies konden de thema's en de kennis meenemen in hun beslissingen, bijvoorbeeld bij de invulling van de Vinex-lokaties." 134 Met de Vinex was alleen een financieel kader gegeven dat op lokaal niveau en decentraal ingevuld moest worden.

Het resultaat van de discussies zou ook in rapporten opgenomen worden die verder in de beleidsvoorbereiding gebruikt zouden moeten worden. Vastgelegd is dat: 'De woonverkenningen op lange termijn een agenda voor de toekomst moesten leveren en een 'aanzet waren voor een maatschappelijke discussie ter voorbereiding van het volkshuisvestingsbeleid. ${ }^{135}$ “

De overdracht van kennis aan de politieke besluitvormers was in de perceptie van de projectgroep gewaarborgd doordat er was gekozen voor een multi-actorbenadering. Die benadering dwong 'de politiek' om zich te verantwoorden als zij zou afwijken in haar beleid van wat maatschappelijk wenselijk wordt geacht. ${ }^{136}$

\subsubsection{BENUTHNG VAN DE RESULTATEN VAN DE TOEKOMSTVERKENNING}

"De Woonverkenningen zijn een 'beetje van iedereen' geworden. ${ }^{197}$

De overdracht van 'kennis in hoofden' is het meest succesvol verlopen. De documenten zijn tijdens het proces in dienst gesteld van de kennisoverdracht in hoofden. Er werd volop gediscussieerd over de documenten. Dit leverde ook kennis op die weer in nieuwe documenten is opgenomen. 
Een goede benutting van de discussies met actoren uit het beleidsveld was dat er meer transparantie kwam in het beleidsvoorbereidende proces: "De Kamer kan niet de uitkomsten van dat proces terzijde leggen. Het projectteam heeft het project ook steeds gecommuniceerd aan de politiek." ${ }^{138}$ Dit is tegelijkertijd ook een nieuw soort legitimatie van beleidskeuzen. In retrospectief vinden de opdrachtnemer dat "het onderzoeksproces een legitimatie van beleid was." 139

\subsubsection{CONCLUSIE}

Opdrachtgever en opdrachtnemer zagen voor het ministerie dezelfde rol weggelegd: regisseur en procesontwerper van de verkenningen waarbij veel ruimte aan de verkenners moest worden gegeven.

Beiden wilden ook kennis vergaren over 'mogelijke' toekomstige ontwikkelingen en beschouwden de wensen van actoren uit de beleidssector, naast wetenschappelijke feiten als bepalende factoren van mogelijke ontwikkelingen. Er was wel een subtiel verschil in perceptie over de verdere verzelfstandiging van de beleidssector. De opdrachtgever wilde deze juist met de woonverkenningen ter discussie stellen en nagaan wat de gevolgen zouden kunnen zijn. De opdrachtnemer nam de verzelfstandiging als uitgangspunt van de discussies.

Net als bij de Brabantse scenario's voor landbouw en ruimtegebruik is ook bij de woonverkenningen een belangrijke rol weggelegd voor de sector. Het lijkt erop dat, waar deze interactie in Brabant vooral benut is om de vervreemding tussen overheid en sector te verminderen, de interactie bij de woonverkenningen vooral is opgezet om een ingezet veranderingstraject van het ministerie verder te bestendigen, en dat ook voor alle medewerkers van DGVH te bevestigen. De wensen van de sector werden met de verkenningen ook verzameld en konden daardoor mede bepalend zijn voor het 'kunnen van het ministerie.

In tegenstelling tot Nederland 2030 is er bij de woonverkenningen geen sprake van spanning tussen de politieke opdrachtgever en de opdrachtnemers. De mening overheerst dat dit komt doordat de Woonverkenningen dieper in de organisatie waren weggezet, waardoor de bewindspersoon niet uitgelokt werd door de Каmer of media om een standpunt in te nemen. Een andere verklaring zou kunnen zijn dat de Woonverkenningen meer beleidsconform waren, en vooral gingen over de vraag naar nieuwe uitdagingen voor het beleid (hoeveel wonen en wat voor wonen). Dit is op zich wel een boeiende paradox: in het bouwprogramma wordt de woonbehoefte gewoonlijk als uitgangspunt genomen, maar in de ruimtelijke ordening de ruimtebehoefte juist een gevaar voor de ruimte die zoveel mogelijk in toom gehouden moet worden, en bovendien het liefst geconcentreerd moet worden in steden. Of anders gezegd, het volkshuisvestingsbeleid is vanuit de traditie meer geneigd het haalbare als leidraad te nemen, en het ruimtelijkeordeningsbeleid tamboereert juist sterk op het primaat van de collectieve waarden van open ruimte boven de individuele behoefte aan meer ruimteconsumptie. 


\subsection{QUESTA: VERPLAATSEN IN DE TOEKOMST}

\subsubsection{INLEIDING}

De verkenning getiteld 'Questa, verplaatsen in de toekomst' is uitgevoerd binnen het ministerie van Verkeer en Waterstaat. Het is gestart in 1997 bij het directoraat voor het Vervoer ter voorbereiding van een nieuw mobiliteitsbeleid. In eerste instantie was dit niet direct voor een nieuwe nationale nota bedoeld maar als een instrument ter ondersteuning van een nieuwe beleidsstrategie. Gedurende de verkenning is het ministerie gereorganiseerd. Questa kreeg toen als opdrachtgever de directie Strategie en Coördinatie onder verantwoordelijkheid van de directeur ir. H. Leeflang. ${ }^{140}$

In het Verantwoordingsrapport worden vier samenhangende redenen genoemd om een verkenning te starten:

1 de samenleving ziet zich geconfronteerd met een blijvende groei in mobiliteit;

2 de dynamiek in de samenleving wordt steeds groter;

3 de onzekerheid over ontwikkelingen in de samenleving brengen gevoelens van twijfel met zich mee;

4 De bereikbaarheidsproblemen zijn zo actueel dat beleidsmakers de handen vol hebben aan het bestrijden van huidige problemen, zonder tijd te hebben om het onzekere in de toekomst te verkennen. De verkenners zien kortom 'de verschillende probleembelevingen onder de beleidsmakers van het ministerie', ${ }^{141}$ door een groeiende onzekerheid, als grootste probleem.

Questa had tot doel:

1 omgevingsscenario's te ontwikkelen die relevant zijn voor te maken keuzen in het mobiliteitsbeleid; en

2 de aandacht binnen de organisatie voor de beleidsomgeving en de onzekere toekomst te vergroten en de kennis en ervaring met daarbij relevante instrumenten verder uit te bouwen.

Concreet zijn samenhangende, mogelijke toekomstscenario's gemaakt die de Nederlandse samenleving in 2030 verbeelden. Ze zoomden in op de wijze van, en behoefte aan, verplaatsingen van personen en goederen die voor Nederland relevant waren. Het verkenningsteam richtte zich met name op 'toekomsten die ons kunnen overkomen', met andere woorden op de feitelijke onzekerheid waar het ministerie mee te maken heeft.

De scenario's zijn in een aantal stappen tot stand gekomen. Als eerste werden het probleem (de onzekere toekomst) en onderwerp (mobiliteit) afgebakend. Vervolgens werden de belangrijkste vertrekpunten van de scenario's gekozen. Daarna heeft het team de eerste generatie scenario's geschreven. Deze zijn becommentarieerd door beleidsmakers en deskundigen van v\&w. Met inachtneming van dat commentaar is de tweede generatie geschreven en wederom becommentarieerd. 
Op basis van de scenario's zijn mobiliteitsbeelden uitgewerkt en is de eindrapportage geschreven. ${ }^{142}$

Questa moest vier producten opleveren:

1 Omgevingsscenario's waarin verschillende, voor mobiliteit relevante, toekomstbeelden van Nederland in 2030 tot uiting komen (zie kader 6).

2 Mobiliteitsbeelden die, theoretisch en intuïtief beredeneerd, samenhangen met de toekomstbeelden. .

3 Kengetallen over mobiliteitsontwikkeling die een kwantitatieve uitdrukking geven aan trends.

4 Kennis en ervaring. Niet alleen met de scenariomethodiek maar ook de tijdens het bouwproces te vergaren kennis en inzichten. ${ }^{143}$

\section{Kader 6 De mogelijke toekomstscenario's In vogelvlucht 144}

\section{Nederland Vrijstaat}

Nederlanders trachten het hoofd boven water te houden. De Europese eenwording is mislukt en dit heeft de economie geen goed gedaan. De 24-uurs economie is een feit en de flexibele arbeidsmarkt speelt daar op in. Dit is overigens geen bezwaar voor de flexibele burger, voor wie zelfredzaamheid voorop staat.

Door de economische impasse en het politieke machtsvacuüm zijn nauwelijks grote veranderingen in verkeer en vervoer te zien.

De individualisering maakt dat het gemotoriseerde individuele ver voer - de auto - een prominente rol speelt.

\section{Waarde(n)vol Nedertand}

Nederland is een samenleving die veel waarde hecht aan de kwaliteit van leven. Men leeft in grote harmonie met elkaar en met de omgeving. Milieu en gezondheid zijn centrale waarden, en men accepteert, sterker nog, men verwacht van de overheid sturend beleid gericht op duurzaamheid. Ook in verkeer en vervoer is de kwaliteit van leven duidelijk waarneembaar: hoewel het aantal verplaatsingen is toegenomen, is in de richting van verkeer en vervoer geheel afgestemd op duurzaamheid en behoud van de leefomgeving. ICT toepassingen worden hierbij optimaal benut.

\section{Grenzenloos Nedertand}

De individuele keuzevrijheid van de burgers staat voorop. Het gaat goed met de Nederlandse economie en er is werk en geld voor iedereen. Nederland is een hoogontwikkelde maatschappij in een economisch geintegreerd Europa. De wereldhandel is geliberaliseerd en de viije markt regeert. In het verkeer en vervoer is dit duidelijk zichtbaar: het individuele vervoer voert de boventoon en keuzen worden ingegeven door economische motieven.

\section{Nederland Polderland}

Nederland is een overlegmaatschappij pur sang. Overheidstaken zijn verregaand verzelfstandigd naar de zogenoemde Pubo's, die in nauw overleg staan met het versterkte en verbrede maatschappelijk middenveld. Strevend naar consensus praat iedereen overal mee. 
De kracht van de continuiteit is sterk en verandering zien we nauwelijks gebeuren, ook niet in het verkeer-en vervoersysteem.

De Oost-Europese economieën zijn opvallend sterk geworden, hetgeen belangrijke gevolgen heeft voor de goederenstroom.

\subsubsection{DE PERCEPTIE VAN DE OPDRACHTGEVER}

"Meer van dit soort innovatieve projecten bij v\&w zijn los van de gewone beleidswoortereiding gedaan. 145

Het initiatief voor een toekomstverkenning kwam van een enthousiaste beleidsmedewerker van de toenmalige Directie Collectief Personenvervoer van DGV. Hij wilde de scenariomethode gebruiken voor een verkenning van toekomstige ontwikkelingen. In eerste instantie had het project geen opdrachtgever en ook geen directe beleidsrelevantie. In de loop van de verkenning zijn er verschillende opdrachtgevers geweest. Het directoraat generaal voor het Vervoer was de eerste. Vervolgens het directoraat-generaal Personenvervoer. Toen de afdeling Strategie en Coördinatie ( $\mathrm{sen} \mathrm{C}$ ) het opdrachtgeverschap overnam is de opdracht formeel vastgelegd.

De opdrachtgever plaatste het project in de startfase buiten de 'hiërarchische' lijn van de organisatie. Daarmee wilde deze ruimte scheppen voor innovatie in de methode van beleidsvoorbereiding. De opdrachtgever verwachtte dat Questa beelden over mogelijke toekomstige ontwikkelingen zou genereren, die geen rekening zouden houden met wenselijkheden die in lopend beleid waren vastgelegd of in de politiek of samenleving aanwezig waren. Ook zou er niet alleen gezocht worden naar waarschijnlijke trends maar juist naar onzekerheden.

\subsubsection{PERCEPTIE VAN DE OPDRACHTNEMER}

De opdrachtnemer was het projectteam Questa, waarin vertegenwoordigers participeerden uit de Directie S en C, het Directoraat Generaal Vervoer (DGV), de Rijksverkeersinspectie, de Adviesdienst Verkeer en Vervoer (AVV), Hoofddirectie Telecommunicatie en Post (HTP), en Rijkswaterstaat Directie Utrecht. De Rijksluchtvaartdienst was niet betrokken. $\mathrm{Zij}$ had al een eigen traject voor toekomstonderzoek uitgestippeld. ${ }^{146}$

Het projectteam voerde regelmatig overleg met de opdrachtgevers en andere directie van v\&w om het project te verankeren in de organisatie. Dit was ook om het leerproces in de organisatie op gang te brengen als onderdeel van de innovatie in de beleidsvoorbereiding: 'de aandacht in de organisatie voor de beleidsomgeving en de onzekere toekomst moest vergroot worden'. Kennis en ervaring met daarbij relevante instrumenten, zoals de scenario's, zouden verder uitgebouwd worden. ${ }^{147}$ 
De opdrachtnemers wilden consistente en plausibele toekomstbeelden maken op basis van feitelijke zekerheden en onzekerheden. De normatieve onzekerheden (wenselijkheden) moesten buiten de scenario's gehouden worden. Pas bij het maken van beleid zouden die aan de orde komen. 'Er zijn geen discussies gevoerd over de 'normatieve onzekerheid'. Dit zijn doelstellingen, beleidsopties en probleempercepties bedoeld. Het projectteam heeft zich gericht op de 'feitelijke onzekerheid', onzekere ontwikkelingen die met beleid nauwelijks te beïnvloeden zijn. Dit is gedaan omdat nieuw beleid met behulp van de scenario's getest moet kunnen worden. Als het beleid al onderdeel is van de scenario's dan is dat onmogelijk te vermijden geweest.' ${ }^{148}$ De 'zekere richting', ook wel de feitelijke zekerheden genoemd, zijn aangedragen door onderzoekers van het Sociaal Cultureel Planbureau, het Centraal Planbureau en de Adviesdienst Verkeer en Vervoer. Ook is kennis en visies van deskundigen benut ${ }^{149}$ en zijn TNO-INRO en LEI-DLO ingehuurd om specifieke berekeningen en kaartbeelden te maken.

De feitelijke onzekerheden, die niet voorspeld kunnen worden in trendstudies, zijn door de onderzoekers en beleidsmedewerkers van v\&w samen vastgesteld. Hierbij waren de scenario's een communicatie instrument. De eerste generatie scenario's is door de opdrachtnemer gebruikt om feitelijke onzekerheden te genereren over de omgeving van huidig en toekomstig beleid. Met name het management van v\&w heeft keuzen gemaakt voor de belangrijkste onzekerheden. In de commentaarrondes werden: “de fouten uit de scenario's gehaald omdat voorkomen moest worden dat mensen konden gaan roepen dat er iets niet klopte." ${ }^{150}$ Bovendien creëerde het projectteam ook commitment bij het hogere management.

\subsubsection{DE ORGANISATIE VAN HET ONDERZOEKSTRAJECT}

De scenario's zijn in drie stappen gebouwd en er zijn drie generaties verschenen. De scenariobouw was een cyclisch proces, dat een aantal buigpunten in het onderzoek opleverde. Voordat het project van start ging is al door de medewerker die het initiatief nam op directieniveau geĩnventariseerd wat de wensen waren op het gebied van het toekomstonderzoek. Na een besluit van de toenmalige DT om een toekomstonderzoek te gaan doen, is een aantal projectdefinities gemaakt. Toen het projectteam voor de eerste keer bij elkaar kwam, stond vast dat: "in ieder geval met scenario's gewerkt zou worden. We wisten verder nog niet wat we zouden doen." ${ }^{151}$ Voordat het onderzoek van start ging had het projectteam ook overleg met de afdeling $Q$ van het ministerie, die ervaring had met de productie van de toekomstscenario's 'Nostradamus' en Creops', en zij won advies in bij Kees van der Heijden, organizational learning specialist aan de universiteit Nijenrode.

De opdrachtformulering en projectdefinities zijn dus in overleg, voornamelijk binnen het ministerie, door de opdrachtnemer en - gever vastgesteld. Deze openheid heeft misschien geleid tot een "toename van het aantal potentiële afnemers 
en/of opdrachtgevers die verschillende eisen stelden aan het onderzoek, bijvoorbeeld meer kwalitatief of meer kwantitatief onderbouwd." 152 Uit dit vooronderzoek concludeerde de opdrachtnemer dat de eerste generatie scenario's vooral kwalitatief moest zijn, en gebaseerd op kennis van de projectteamleden en een aantal externe deskundigen. Variatie op feitelijke onzekerheden was het uitgangspunt en daarnaast werd in ieder scenario een aantal vaste aannames over ontwikkelingen in de toekomst gedaan.

\section{Buigpunt 1997}

Het eerste buigpunt ontstond als gevolg van de interne commentaarrondes tijdens de voorbereiding van de tweede generatie scenario's. In een ministeriebrede discussie werd de impact van feitelijke onzekerheden en de mogelijke ontwikkelingen voor de mobiliteit nader bepaald. Toen bleek er behoefte te zijn aan meer zekerheden zodat de 'feitelijke onzekerheid' en de 'mogelijke toekomsten' "voor sommige beleidsmakers duidelijker en aanvaardbaarder werden. ${ }^{153^{n}}$ Het projectteam had rekening gehouden met een wens tot verdere kwantificering van de scenario's: “De verhalen in deze publicatie zijn alleen voor intern gebruik. Er moeten nog veel kwantitatieve verbanden worden aangebracht met 0. a. de recente CPBscenario's en anderszins'. ${ }^{154}$

Twee aanleidingen voor de kwantificering van de scenario's waren de bedrijfscultuur van v\&w en discussies binnen het projectteam over het gebruik van de CPB -scenario's. De bedrijfscultuur van v\&w was een aanleiding om de scenario's verder te kwantificeren. Met name op verzoek van beleidsmakers zijn de scenario's aangepast: "In de bedrijfscultuur van v\&w moet een beleidspakket doorberekend worden. En liever niet in drie cijfers, als er maar één nodig is. Voor beleidsmakers is dat lastig." De bedrijfscultuur van het v\&w wordt door geïnterviewden getypeerd als een 'sterke getallencultuur' waarin medewerkers 'lekker willen rekenen'. 155

Een tweede aanleiding voor de aanpassing van de Questa scenario's waren de CPB scenario's en de discussie die zij opriepen binnen het team. Deze scenario's hebben, net als de rest van het onderzoek van het CPB, een hoog waarheidsgehalte voor beleidsmakers en zij leveren een belangrijke input aan beleid en onderzoek. Uit de interviews blijkt dat de vervlechting van de Questa scenario's met die van het CPB een strijdpunt is geweest binnen het projectteam. Een aantal deelnemers aan het projectteam vond vervlechting tussen Questa en CPB wenselijk, anderen niet. De CPB scenario's waren belangrijk omdat: "Het CPB gezag heeft als het gaat om het maken van scenario's. Die scenario's staan nergens ter discussie. Op economisch gebied leveren zij gezaghebbende kennis over ontwikkelingen.” ${ }^{156}$ Bovendien leefde het idee dat het een voordeel zou zijn dat op deze manier een afstemming tussen verkenningen (bijv. NL 2030, Questa en de NVK) zou plaatsvinden. Dit zou op zijn beurt meer integrale beleidsnota's tot gevolg hebben. Tegenstanders waren van mening dat de scenario's op deze manier een 'schijnwaarheid' zouden gaan construeren. Er wordt met meer dan één scenario gewerkt om aan te geven dat de toekomst onzeker is. Dat idee zou door het gebruik van de CPB scenario's ontkracht 
worden. Bovendien zou integraal beleidsvoorbereidend onderzoek wellicht problemen opleveren voor de relevantie van het onderzoek voor het specifieke beleidsterrein.

Tegelijkertijd was er op dit buigpunt voor het projectteam Questa aanleiding om in de scenario's meer wenselijkheden te gebruiken. De rol van de overheid, de sturingsfilosofie, en een aantal 'onvermijdbare'157 beleidsaannames kregen op verzoek van de opdrachtgevers en andere beleidsmakers een meer prominente plaats in de scenario's. Door deze aanpassingen combineerden de scenario's mogelijke toekomstbeelden met wensbeelden.

Het management wilde dat de sturingsfilosofie van de overheid meer naar voren zou komen als één van de onzekere factoren in de toekomst met veel impact. ${ }^{158}$ Ook bleek het voor de opdrachtgever en -nemers in een aantal gevallen ondenkbaar, dat de beschreven toekomst van de mobiliteit tot stand zou komen zonder expliciet verkeer- en vervoerbeleid. Ook aannames over beleid op andere terreinen, bijvoorbeeld van VROM, waren volgens de deelnemers niet uit de scenario's te houden. Dit was het 'onvermijdbare' nieuwe beleid dat later is opgenomen in de scenario's. 159

\section{Knikpunt 1998}

Een knikpunt ontstond na de productie van de derde ${ }^{160}$ generatie scenario's in juli 1998. Voor het projectteam verschoof op dit knikpunt het doel van het genereren van kennis naar het faciliteren van discussies met de scenario's als communicatie instrument. Provincies en regiobesturen verzochten het projectteam om de scenario's als instrument te kunnen gebruiken om de feitelijke onzekerheden voor de regio of Provincie vast te stellen. Dit ter voorbereiding van het nationale svv III c.q. NVVP.

De scenario's zijn aangepast op regionaal niveau. In bijvoorbeeld de bestuursregio Utrecht zijn meer gegevens over de regio toegevoegd: " Ter voorbereiding en als vervolg op de reeds gevoerde bestuurlijke gesprekken is door de ambtelijke projectgroep SVV III/ NVVP een tweetal werkbijeenkomsten gehouden waarin, naast een korte beschrijving van de huidige kwaliteiten in de regio, een verkenning van een viertal scenario's is uitgevoerd. Hiervoor is gebruik gemaakt van de Questa scenario's." ${ }^{161}$ Het valt buiten de reikwijdte van deze analyse om na te gaan waar de scenario's gebruikt zijn.

Een tweede aanleiding voor de veranderingen op dit knikpunt was het voornemen van het projectteam om de scenario's als testomgeving voor de Perspectievennota en het NVVP te laten fungeren. Deze doelverschuiving was al ingecalculeerd en leidde tot het herschrijven van de derde generatie voor bijvoorbeeld de themagroepen die er ter voorbereiding van de Perspectievennota waren. 


\subsubsection{DE ORGANISATIE VAN DE OVERDRACHT}

In aanvang van het project is niet vastgelegd hoe de scenario's gebruikt moesten gaan worden in de voorbereiding van de perspectievennota en het NVvP. Formeel was de productie van de laatste generatie scenario's de eindopdracht van het projectteam. In een reconstructie zijn echter drie manieren van overdracht te abstraheren:

1 in de hoofden, als eye-opener voor beleidsmakers;

2 schriftelijk via rapporten;

3 evaluatief, door de scenario's te gebruiken als testomgeving.

De overdracht van kennis moest direct plaatsvinden in de workshops en conferenties. Deze zouden kennis in hoofden opleveren. Parallel aan dit proces zou nieuwe kennis gegenereerd moeten worden die in documenten opgenomen zou kunnen worden. De projectleiders van Questa, de perspectievennota en het NVVP informeerden elkaar mondeling over de stand van zaken en wilden op deze manier de overdracht van kennis van het ene project naar het andere verzorgen. Dit was een formele afspraak maar voor medewerkers die niet direct betrokken waren leek het "alsof dit contact tussen de projectleiders van bovenaf door de opdrachtgever werd opgelegd." 162

De overdracht van kennis zou volgens het projectteam ook schriftelijk kunnen verlopen door de toekomstbeelden te gebruiken als testomgeving voor beleidsopties en perspectieven die elders in het ministerie geformuleerd werden. Door de opties en perspectieven in de mogelijke toekomsten te plaatsen zou gekeken kunnen worden of zij wel houdbaar zijn in dat scenario.

\subsubsection{BENUTTING VAN DE RESULTATEN VAN DE TOEKOMSTVERKENNING}

"De themagroepen waren al voor driekwart klaar, toen is nog geprobeerd om met die scenario's te werken. Dat was bovendien midden in de zomervakantie." 163

Het projectteam Questa heeft zich uiteindelijk in de overdracht vooral toegelegd op kennis in 'hoofden'. Daar zijn ook de meeste positieve resultaten mee behaald. Dit gebeurde door, aan de hand van de documenten, discussies te organiseren of de documenten te gebruiken op bijeenkomsten.

De kennis in de documenten is nauwelijks overgedragen aan de beleidsmakers van de Perspectievennota en het NvvP Dit had minimaal drie oorzaken

1 tijdgebrek. Tijdgebrek aan de kant de beleidsmakers was een reden om de scenario's niet als testruimte voor beleid te gebruiken. De beleidsmakers stonden onder druk om nota's te produceren. De producten die door Questa ontwikkeld zijn voor de Perspectievennota kwamen te laat. Ook voor het NVVP zijn de scenario's (nog) nauwelijks gebruikt. “Er zijn plannen om de scenario's te gebruiken als het concept NVVP er is, dan is er meer tijd." 164 
2 geen bereidheid aan de kant van de beleidsmakers. De bereidheid om de scenario's werkelijk te gebruiken was niet groot omdat: "Beleidsmakers moeten kunnen voelen dat het iets oplevert als zij die scenario's gebruiken. Dat was niet zo bij Questa. Het zou leuk zijn geweest als dat in een grote klapper was gegaan." 165 Bovendien was een aantal mensen niet bereid om rekening te houden met onzekerheden in de toekomst: "Het bleek moeilijk om binnen het ministerie het nieuwe toekomstdenken waarin feitelijke onzekerheden centraal staan, te verankeren. Ook na Questa is dit niet gelukt ondanks dat veel mensen betrokken zijn geweest bij het project." 166

Ook blijkt dat er weinig bereidheid was tot een uitgebreide reflectie op de slagingskansen van het geformuleerde beleid. De testfunctie van de scenario's op toekomstvastheid was overbodig omdat: “Er met terugvalopties een slag om de arm werd gehouden om eventueel zwakke plekken in het beleid op te vangen. Maar beleidsmakers stellen de sturingsfilosofie niet expliciet ter discussie. De meeste beleidsmakers gaan er vanuit dat sturing geen kwestie van 'kunnen' is maar van 'willen". ${ }^{167}$

3 het project stond buiten de lijn van de organisatie en het gebruik van de kennis werd daardoor niet afgedwongen. De scenario's zijn nog nauwelijks gebruikt in de voorbereiding van het NVVP omdat er geen verplichting was aangegaan door de opdrachtgevers over de overdracht van de kennis aan de makers van de beleidsnota's.

\subsubsection{CONCLUSIE}

Questa illustreert in een aantal opzichten de dilemma's die optreden bij toekomstgericht onderzoek. Questa was in aanzet innovatief van karakter. De verkenning zou zich moeten richten op mogelijke toekomsten, zelfs als deze kritische vragen zou oproepen aangaande het huidige beleid. Om deze ruimte te scheppen is het project op aanzienlijke afstand van de bestuurlijke en beleidsmatige kern van het ministerie gezet. 'Gaat uw gang opdrachtnemers en wij, opdrachtgevers, zien wel hoe het loopt en zullen naar bevind van zaken handelen', lijkt het credo. De casus laat vervolgens zien dat de beleidsbehoeften toch gaan domineren in het verkenningstraject. Eerst wordt gedacht in termen van beleidsarme, kwalitatieve toekomstbeelden, waar vervolgens mobiliteitsbeleid voor zou kunnen worden ontwikkeld. Later wordt aan twee behoeften van beleidsmakers tegemoet gekomen.

Ten eerste voert de opdrachtnemer kwantitatieve gegevens toe om daarmee houvast voor beleidsmakers te vergroten (meten is weten). Ten tweede worden beleidsmaatregelen en beleidseffecten ingevoerd. Daarmee verschuift de verkenning niet alleen van mogelijke naar wenselijke toekomsten, de verkenning reproduceert daarmee ook steeds meer de opvattingen die leven binnen het departement over het belang van het eigen beleid. Het aantal vrijheidsgraden van de verkenning neemt daarmee af. 
Verder was Questa bedoeld als een hulpmiddel voor beleidsontwikkeling, dat echter in de praktijk maar in beperkte mate wordt gebruikt. Ondanks de tussentijdse aanpassingen op verzoek van beleidsmakers, blijkt Questa niet zodanig te voldoen aan de behoefte van beleidsmakers, dat ze er tijd voor vrij maken in hun agenda. In dat licht is het eerder aangehaalde citaat veelzeggend: "Er zijn plannen om de scenario's te gebruiken als het concept NVVP er is, dan is er meer tijd." Het eigen willen (als we het NVVP hier even beschouwen als een departementale wilsbeschikking) lijkt centraal te staan bij het departement. De dominante gedachte lijkt nog steeds te zijn dat zo'n wilsbeschikking goed is te geven zonder expliciete reflectie op de ontwikkeling van de samenleving. Er wordt wel geprobeerd om hier wat aan te veranderen. In de perspectievennota is bijvoorbeeld een meer bescheiden sturingsambitie verwoord met meer decentralisatie en flexibiliteit. Uit de reconstructie blijkt dat dit in praktijk nog een onderstroom is. Ook in deze casus overheerst het klassieke sturingsdenken. Noch bij de opdrachtnemer, noch bij de opdrachtgever bestaat een helder beeld over de vraag hoe toekomstverkenning valt in te weven en te benutten voor strategische beleidsprocessen zoals die van het NVvP.

De belangwekkende ambitie tot innovatie heeft niet geresulteerd in aanwijsbare innovaties in het beleid van het ministerie. Bij Questa is wel geëxperimenteerd met combinaties van kwalitatieve en kwantitatieve verbeelding en met combinaties van mogelijke en wenselijke toekomsten. Een synthese die zowel in termen van verkennen (vooral van belang op het moment dat dit nieuwe inzichten oplevert) als in termen van beleidsrelevantie (vooral van belang daarbij is de legitimatie van het eigen beleid en de eigen positie) aanspreekt is nog niet bereikt. 


\section{NOTEN}

1 Interview 30 September 1999

2 Interview 30 september 1999

3 Interview 30 september 1999

4 Uit: Brabant Manifest, 1997:3

5 Uit: Brabant Manifest, 1997:10-11

6 Interview 17 januari 2000

7 Interview 17 januari 2000

8 Interview 17 januari 2000

9 Brabant Manifest 2050, 1997:10

10 Brabant Manifest 2050, 1998, inleiding

11 Interview 30 september 1999

12 Interview 17 januari 2000

13 Idem

14 Idem

15 Interview 30 september 1999

16 Uit een brief aan GS over de voortgang van het project.

17 Plan van Aanpak 17 juni 1999

18 Interview 30 september 1999

19 Aanvulling van het projectbureau Brabant 2050 met recente informatie. Dit o.a. naar aanleiding van de presentatie in januari 2000 (17 februari 2000)

20 Interview 30 september 1999

21 Interview 30 September 1999

22 Interview 30 september 1999

23 Het Manifest en de Scenario's voor landbouw en ruimtegebruik zijn onafhankelijk van elkaar ontwikkeld. Op deze manier werden de projecten niet aan elkaar gebonden. "Dat was een beleidsmatige keuze om de handen vrij te houden." (interview 16 september 1999)

24 Interview 17 januari 2000

25 'Meten met drie maten, discussienota landbouwverkenning' en Scenario's voor Landbouw en Ruimtegebruik in Brabant (1998)

26 Scenario's voor landbouw en ruimtegebruik, 1998

27 Interview 17 januari 2000

28 Uit interviews op 16 september 1999 en 30 september 1999

29 Interviews op 7 september 1999, 13 september 1999 en 14 september 1999 
$$
\begin{aligned}
& \text { het leven geroepen. Het bureau zou de actuele en toekomstige toestand van } \\
& \text { natuur, bos en landschap moeten beschrijven, in afhankelijkheid van de }
\end{aligned}
$$
autonome maatschappelijke ontwikkelingen (economie, ruimte, milieu) en het gevoerde beleid.

\section{Idem}

$59 \quad$ Natuurverkenning 1997

60 Interview 20 september 1999 en Voorwoord van de Natuurverkenningen 1997 
61 Interview 20 september 1999

62 Idem

63 Idem

64 Idem

65 Idem

$66 \quad$ Interview 28 september 1999

67 Interview 21 december 1999

68 Interview 20 september 1999

69 Interne evaluatie

70 Interview 20 september 1999

n Natuurverkenning 97, 1997: 13

72 Interview 21 december 1999

73 Interview 20 september 1999

74 Interview 20 september 1999

75 Idem

76 Interview 20 september

$\pi$ Interne evaluatie

$78 \quad$ Interview 21 december 1999

79 RPD, 'Verkenning Ruimtelijke Perspectieven (VRP), Plan van Aanpak', 1995

80 RPD, Verkenning van ruimtelijke perspectieven, Plan van Aanpak, 1995

81 Verkenningen Ruimtelijke Perspectieven, PvA, 1995:7

82 Idem

83 Werkdocument 2, 1996: 5.

84 Nederland 2030 - Discussienota, 1997

85 RPD, Verkenning Ruimtelijke Perspectieven, Plan van Aanpak, 1995

86 Interview, 20 januari 2000

87 'Juiste vragen' zijn vragen die door de samenleving als relevant worden aangemerkt. De verkenning moet ook het draagvlak voor nieuw ruimtelijk beleid verbreden. (Plan van Aanpak, 1995)

88 Verkenningen Ruimtelijke Perspectieven, PvA, 1995

89 Verkenningen Ruimtelijke Perspectieven, PvA, 1995

$90 \quad$ Interview 7 september 1999

91 Interview 7 september, 1995:16

92 Verkenningen Ruimtelijke Perspectieven, PvA, 1995

93 Interviews 7 en 16 september, 21 december 
Interview 20 januari

Communicatie en nazorg Nederland 2030, plan van aanpak: blz.2.

Dubbelinterview 7 september 1999

Interview 19 oktober 1999

RPD, Verkenningen Ruimtelijke Perspectieven, Plan van aanpak, 1995:5

Verkenningen Ruimtelijke Perspectieven, PvA, 1995:16

Verkenningen Ruimtelijke Perspectieven, PvA, 1995:16

Dubbelinterview 7 september 1999

Interview 19 oktober 1999

In de standpuntbepaling zit ook kritiek van de raad op de verkenning:

'Nederland 2030 is gepresenteerd als een eerste stap in een langlopend proces van nieuwe ruimtelijke beleidsvorming. Daarop kan evenwel niet worden gewacht; nu al zijn beleidskeuzen nodig'.103 Dit is een mooi voorbeeld van de confrontatie tussen de dagelijkse beleidspraktijk, waar de VROM-raad zich op richt en ook dicht tegenaan gaat zitten met Stedenland+ en verkenners.

Interview 16 september 1999

Dubbelinterview 7 september 1999

Interview 19 oktober 1999

Interview 21 december 1999

Milieutypen en transformatie, 1997: voorwoord

Woonverkenningen, 1997: 112

Woonverkenningen, 1997:7

Woonverkenningen MMXXX 1997: 44, 45, 68t/m 73, 76 t/m 101

Woonverkenningen MMXXX, 1997: 29 en 30

Woonverkenningen MMXXX, 1997: 15 en 16

Interview 21 December 1999

Idem

Idem

Idem

Idem

Idem

Interview 21 December 1999

Interview 21 december 1999

Idem

Idem

Interview 16 september 1999 
Idem

Interview 16 September 1999

Interview 16 september 1999

Interview 16 september 1999

Interview 21 december 1999

Interview 21 december 1999

Woonverkenningen 1997: 110

Interview 16 september 1999

Interview 21 december 1999

Idem

Milieutypen en transformaties: Voorwoord, 1997

Interview 16 september 1999

Interview 21 december 1999

Interview 16 September 1999

Interview 16 September 1999

Verantwoordingsrapport Questa, 1998:3

Verantwoordingsrapport Questa, 1998:5

Verantwoordingsrapport Questa, 1998: 9

Verantwoordingsrapport Questa, 1998:5 en 6

Ministerie van V\&W, Samenvatting Questa, 1998

Interview 19 oktober 1999

Interview 3 september 1999

Verantwoordingsrapport Questa, 1998: 6 en 7

Verantwoordingsrapport Questa, 1998: 6

Vier verhalen over de toekomst van Nederland, 1997

Interview 3 september 1999

Interview 22 september 1999

Interview 22 september 1999

Interview 19 oktober 1999

'Vier verhalen over de toekomst van Nederland' 1997:inleiding

Interviews 3 en 22 september 1999

Interview 22 september 1999

Onvermijdbaar' is 'als het ware afgedwongen door de samenleving in dat scenario' (Verantwoordingsrapport, 1998, p11).

Interview 22 september 1999 
159 Verantwoordingsrapport Questa, 1998:10 en 11

160 De gepubliceerde tweede generatie scenario's is eigenlijk de derde versie en wordt ook wel de derde generatie genoemd.

161 Provincie Utrecht, 'Verslag van de scenario verkenning verkeer en vervoer 2020-2030 in de Provincie Utrecht', 1998

162 Interview 22 september 1999

163 Dubbelinterview 22 september 1999

164 Interview 19 oktober 1999

165 Interview 3 september 1999

166 Dubbelinterview 22 september 1999

167 Dubbelinterview 22 september 1999 


\section{VERGELIJKENDE ANALYSE}

\subsection{INLEIDING}

In dit hoofdstuk wordt in vergelijkend perspectief een aantal conclusies getrokken over toekomstverkenning in relatie tot beleidsontwikkeling.

In de paragraaf 4.2. staan we stil bij het verschijnsel verkenning dat zich kan verheugen in een toegenomen populariteit. Paragraaf 4.3. gaat in op de inhoud die in verkenningen wordt nagestreefd. In de paragrafen 4.4. tot en met 4.8. komen de onderscheidende deelaspecten van de ex-postanalyse aan bod. Paragraaf 4.9. bevat een aantal afsluitende waarnemingen.

\subsection{HET VERKENNEN ALS POPULAIRE ACTIVITEIT}

Verkennen van de toekomst is populair. De zes geanalyseerde verkenningen vormen een deelverzameling in een omvangrijke reeks. Op zich is deze constatering al de moeite waard om even bij stil te staan. De verklaring hiervoor ligt in de dynamiek en complexiteit van de samenleving. In alle verkenningen wordt daaraan gerefereerd. In de dagelijkse korte termijn hectiek van beleid dreigt de strategische dimensie en de visievorming ondergesneeuwd te raken. Overheden zijn op zoek naar methoden om met de dynamische en complexe omgeving om te gaan en daarbij rekening te houden met wensen van actoren in hun beleidsveld. Verkenningen zijn een voorbeeld van zo' $n$ methode.

Vrijwel elke zich respecterende organisatie of eenheid lijkt bezig met een voor de eigen organisatie relevante toekomstverkenning. De vraag is waarom elke organisatie een visie wil ontwikkelen, en met name waarom er geen samenwerking tussen verschillende overheden tot stand komt, daar waar ze grotendeels in dezelfde complexe en dynamische omgeving opereren. Opvallend is dat elke verkenning zijn eigen couleur locale heeft. De toekomst wordt geschetst in concepten en beelden van de (omgeving van de) beleidssector waarvoor de verkenning wordt gemaakt. De indruk bestaat dat daarmee ook een aanzienlijk deel van de sectorale beleidsovertuigingen worden meegenomen. Daarmee wordt niet ontkend dat verkenningen worden ingezet om het 'willen' in de samenleving te achterhalen, zoals bij de Scenario's en het Manifest in Brabant, de Woonverkenningen en Nederland 2030 onder andere het doel was. Maar ook deze verkenningen kunnen zich niet geheel onttrekken aan de eigen logica van de organisatie en de sector.

Verkenners, beleidsmakers, onderzoekers en politici hebben een bewustzijn dat verkenningen breder getrokken moeten worden. Bij de aanvang van de meeste verkenningen wordt uitgesproken dat het moet gaan om een interorganisatorisch proces, waarbij de kennis vanuit allerlei gremia wordt benut. Deze ambitie wordt gedurende het proces meestal teruggeschroefd. Dit is bijvoorbeeld het geval bij Questa en Nederland 2030. Questa is vooral een intern Verkeer \& Waterstaat gebeuren. Nederland 2030 is wel extern georiënteerd, maar ook daar geraakt de 
verkenning toch nauwelijks buiten de 'traditionele' ruimtelijke ordeningswereld. $\mathrm{Er}$ is wel voor gekozen om de verschillende nationale verkenningen te synchroniseren. Toch blijft het hier nog wat veel bij intenties alleen. Er is uiteindelijk ook wel van elkaars kennis gebruik gemaakt. Met name de CPB scenario's komen in de verschillende casus terug of vormen zelfs de basis voor andere verkenningen, zoals de NVK 97 en Woonverkenningen en NL 2030. De meeste verkenners geven aan dat zij in andere verkenningen, zoals die van het CPB, meer specifieke kennis over hun beleidsveld of voor hun organisatie misten.

De gevoelde noodzaak tot het breder trekken van verkenningen blijkt ook uit de afspraken om de Rijksnota's beter op elkaar af te stemmen. De door minister de Boer voorgestelde integratie van die nota's in één nota Omgevingsbeleid heeft het niet gehaald. Verschillende leden van het kabinet wensten zich niet te schikken in een regie van VROM, en de RPD en DGM zagen dat ook als interventie in hun eigen veld van competentie.

In de uitvoering van de verkenningen lijkt het erop dat overheden, die meer denken in termen van het politieke, ideologische 'willen' dan gangbaar is in de private sector, de ruimte nemen om toekomsten te scheppen. In de private sector leidt marktwerking tot de behoefte om risico's te verminderen. Een robuustheidstest op strategische investeringsbeslissingen wordt daar gezien als een onmisbare toets aan de wetten van de markt. De overheid kent geen vergelijkbare rendementseisen. De straf voor het negeren van de efficiency eis is heel wat minder zwaar dan de overtreding van de marktwetten.

In het bedrijfsleven wordt de veeleisend klant en de dynamiek van voorkeuren aanvaard als een fact of live. Om daar op adequate wijze op in te kunnen spelen (het kunnen) is een aanzienlijke hoeveelheid research en development nodig. Bedrijven kunnen dat niet zelf betalen en gaan daarom over op gezamenlijke trajecten van R\&D. ${ }^{1}$ Bij de overheid blijkt daarvan nauwelijks sprake. De sense of urgency die het bedrijfsleven in de armen van de ander drijft, wordt bij de overheid (nog) niet gevoeld. Minister De Boer heeft bijvoorbeeld wel getracht tot meer geïntegreerde kennisverzameling te komen, maar dat is gestuit op de verkokering. Zelfs binnen één ministerie worden verschillende toekomstverkenningen uitgevoerd. In de private sector leiden gezamenlijke inspanningen tot een intensere verkenning en verzameling van gegevens en daarmee tot beter inzicht. In de overheidswereld blijkt dat maar in beperkte mate het geval. Hoewel velen zich voor hun basisgegevens baseren op dezelfde onderzoeksbronnen (bijv. CPB), wordt vervolgens een rijke schakering aan toekomstbeelden ontwikkeld. Iedere organisatie refereert wel aan deze verwachtingsbeelden, maar bouwt daarop toch geheel eigen toekomstbeelden.

Bij de Woonverkenningen, de Scenario's voor landbouw en ruimtegebruik en Nederland 2030 is wel ruimte gecreëerd om gezamenlijk mogelijke toekomsten te construeren. Dit is niet altijd even goed terechtgekomen in de uiteindelijke over- 
dracht, doordat er interventies zijn gepleegd door bijvoorbeeld beleidsmakers van de eigen organisatie of door politici. Vermoedelijk waren de Woonverkenningen echter niet tot een innovatieve aanpak gekomen als de efficiency eis en de wens tot coördinatie al te zwaar was ingezet. Schijnbare inefficiëntie in de kennisverzameling op het niveau van de verkenningen kan in een beleidsinnovatie of een strategische besluitvorming juist positief uitwerken. Niet alleen omdat andere actoren toegang krijgen tot de besluitvormingsarena maar ook omdat het een grote variatie aan keuzemogelijkheden voor beleid creëert. Een voorbeeld hiervan is de beleidsconcurrentie tussen DGM en RPD over duurzaam ruimtegebruik die leidt tot concurrerend onderzoek naar bijvoorbeeld strategie van twee netwerken, ontkoppeling van milieu en economie, de 'lagen' benadering, multi-criteria analyse in de effectrapportages.

Ten slotte moet niet worden vergeten dat verkenningen benut worden voor andere doelen dan toekomstkennis. Zij kunnen bijvoorbeeld bijdragen aan een legitimering van beleid en om vergroting van draagvlak voor toekomstvisies van overheden. Zo worden de Natuurverkenningen onder andere benut om de verhouding tussen beleidsmakers en onderzoekers in deze sector te herdefiniëren en om invulling te geven aan een planbureaufunctie. En zijn de Woonverkenningen gebruikt om draagvlak voor beleid te creëren.

\subsection{DE INHOUD VAN HEDENDAAGSE TOEKOMSTVERKENNINGEN: INGEWIKKELDE MENGVORMEN}

Toekomstverkenningen zijn er deels op gericht om kennis te genereren in de traditionele objectieve zin. De Natuurverkenningen zijn daarvan het meest zuivere voorbeeld. Wie echter zoekt naar strikt wetenschappelijk gefundeerde verkenningen in de klassieke traditie ('ontdek de feiten'), komt niet ver. Een aanzienlijk deel van de gegenereerde kennis betreft mogelijke en wenselijke toekomstbeelden. De verbeelding speelt daarbij een minstens zo belangrijke rol. Kennis wordt ons inziens terecht met deze drie domeinen verbonden. Waar we evenwel op gestuit zijn, is de tamelijk ondoordachte menging van kennis over trends, denkbare ontwikkelingen en wensbeelden. In alle verkenningen worden mixen van denkbare, wenselijke en (vanuit extrapolaties uit het verleden te distilleren) waarschijnlijke toekomsten verkend. De onderscheiding tussen deze drie kennisdomeinen wordt in onvoldoende mate bewaakt. Vaak wordt bij het schetsen van waarschijnlijke toekomsten al rekening gehouden met (op voorhand als succesvol gepostuleerde) voortzetting van beleid. De Natuurverkenningen bevatten bijvoorbeeld een milieuscenario gebaseerd op het terugdringen van verdroging dankzij bestaand en geīntensiveerd beleid.

Nog problematischer is het wanneer denkbare toekomstbeelden na verloop van tijd geïnterpreteerd worden als wensbeelden. Dit komt pregnant naar voren in 
Nederland 2030. De vier gepresenteerde denkbare toekomsten zouden later worden voorzien van beleidsacties die passen bij deze toekomst. Na enige tijd spreken zowel de minister als de opdrachtnemers evenwel van voorkeursscenario: de toekomstbeelden zijn vanaf dat moment gemeten aan de bruikbaarheid voor bestaand beleid. Een eigenstandige functie als brenger van kritische boodschappen aangaande de steun voor beleid, de uitvoerbaarheid van beleid, of oproep tot nieuw beleid, verdwijnt dan grotendeels naar de achtergrond. In het Brabant Manifest is wel een werkbaar onderscheid gemaakt in waarschijnlijke, denkbare en wenselijke toekomsten. Ook in Questa heeft men geprobeerd een scheiding aan te brengen in feitelijke zekerheden (weten), feitelijke onzekerheden (weten dat we niet weten) en normatieve onzekerheden (wensen). In eerste instantie moesten de scenario's mogelijke toekomstbeelden voor de omgeving van mobiliteit opleveren. $\mathrm{Na}$ commentaarrondes is er 'onvermijdbaar' beleid toegevoegd en zijn er aannames over de sturingsfilosofie in de scenario's gevoegd (dit zijn de normatieve onzekerheden). In de Woonverkenningen zijn twee trajecten uitgezet. In het ene traject werden de basisverkenningen gedaan door onderzoeksinstellingen. In het discussietraject werden weten en willen vermengd. Maar de input uit het discussietraject werd wel als een onderdeel van het 'kunnen' beschouwd evenals de input uit het onderzoekstraject, in ieder geval voor de duur van de verkenningen.

Ten slotte zijn verkenningen vooral gericht op de integratie van kennis in toekomstbeelden, meer dan op het presenteren van 'de feiten'. Het ontwerpen van deze toekomstbeelden is een vertaalslag, die vaak in kleine kring wordt uitgevoerd. Soms wordt individuen gevraagd een beeld te schetsen gebaseerd op visies waarin wenselijk en mogelijk vermengd worden (Brabants Manifest). Soms schetst het team van opdrachtnemers dat beeld zelf en probeert zij daarbij het wenselijke uitrukkelijk uit de beelden te houden. In andere gevallen heeft het team van verkenners van begin af aan overleg met de opdrachtgevers of het (hoger) management van de organisatie over de belangrijke zekerheden en onzekerheden die in de scenario's opgenomen moeten worden. Ook externe onderzoekers (Brabantse scenario's en Natuurverkenningen) maken de toekomstbeelden, in het eerste geval in nauwe interactie met de sector en in het tweede geval geheel en al vertrouwend op de eigen professionaliteit. Essentieel is evenwel dat kennis meer het combineren van gedachten en feiten tot min of meer samenhangende beelden lijkt te worden dan 'het verzamelen van feiten'. Of om het wat prikkelend te formuleren, feiten zijn er te over, het gaat bij verkennen klaarblijkelijk meer om het construeren van betekenisvolle beelden uit de veelheid aan feiten.

\subsection{HET OPDRACHTGEVERSCHAP}

Hoewel in de casus gepoogd wordt met een eenduidige en stabiele opdrachtgever te werken, blijkt het opdrachtgeverschap nauwelijks eenduidig te omschrijven. Met name bij de rijksoverheid bestaan er verschillende lagen van opdrachtgevers, waardoor de communicatielijnen lang worden en verschillende interpretaties van 
de opdracht ontstaan. Er is regelmatig sprake van een gemengde opdrachtgevers/ -nemersrol: men voegt een beetje eigen inzicht toe en voert een beetje uit. Ten slotte treedt veelvuldig een verandering op in opdrachtgever in persoon en rol gedurende de verkenning (zie Questa voor een ambtelijke rol- en persoonsverandering; zie bijv. Nederland 2030 voor politieke rol- en persoonsverandering. Mede daardoor blijkt het moeilijk, zo niet onmogelijk, om tot een adequate, in de toekomst te consolideren opdrachtformulering te komen. Daar waar de lijnen kort zijn, lijkt het ontbreken van een opdrachtformulering minder problematisch. Dit was bijvoorbeeld in Brabant zo, maar ook in de Woonverkenningen, waarin opdrachtgever en -nemer het kernteam vormden dat de verkenningen aanstuurde. De consequenties van rolwisselingen zijn aanzienlijk, zowel voor de opzet van de verkenning, als voor de benutting. Gezien de regelmaat waarmee het verschijnsel van rol- en persoonswisseling voorkomt valt niet aan de conclusie te ontkomen dat verkenners moeten leren leven met zulk een meervoudig en wisselend opdrachtgeverschap.

Uit de casus leiden we af dat opdrachtgevers zich in een dilemma bevinden. Enerzijds willen opdrachtgevers dat de verkenning zich verheft boven de dagelijkse beleidspraktijk. Ze onderkennen het belang van toekomstgerichte en vernieuwende verkenningen. Tegelijkertijd willen en/of kunnen ze er niet onder uit de verkenning te beoordelen in het licht van de kansen en bedreigingen voor het dagelijkse beleid. Zo wacht Gedeputeerde Van Geel de reacties op het Manifest eerst af vooraleer een vervolgdiscussie te starten, en ziet Minister de Boer zich genoodzaakt om tijdens de verkenning Nederland 2030 een voorkeur uit te spreken voor Stedenland als wensbeeld. Politiek verantwoordelijken lopen risico's met verkenningen die te ver voor de muziek uitlopen. Als men deze toch wil, bestaat de neiging om de opdracht daartoe ver weg te zetten in de eigen organisatie, of liever nog bij een extern instituut met een planbureaufunctie. Tegelijkertijd erkennen ze dat deze oplossingen de dreiging in zich hebben dat de resultaten nauwelijks benut worden in de organisatie. Zo neemt Van Geel waar dat vooral de onderzoeksinstituten veel geleerd hebben van de Brabantse scenariobouw. Voor Nederland 2030 ziet Lever bijvoorbeeld in retrospectief dat er veel kennis is verzameld en gecombineerd, maar dat de discussie aan het eind zich vooral toespitste op slechts één element, namelijk de keuze voor stedenland en een eventuele toevoeging van elementen van stromenland.

Kortom, de conclusie is te trekken dat opdrachtgevers zich bij de formulering van de opdracht, de tussentijdse wijzigingen en de wijze van benutting laten leiden door de logica van de eigen beleidssituatie. Verkenningen (weten) staan in dienst van het eigen willen. Er moet binnen vier jaar gescoord worden. In geen van de onderzochte casus kan aanwijsbaar gesproken worden van een doelbewust proces van gemeenschappelijke wilsvorming, zoals in het ideaaltype van netwerksturing gesteld. Wel wordt in drie verkenningen (Nederland 2030, Woonverkenningen en Brabantse scenario's) nadrukkelijk met de sector gecommuniceerd. Dat heeft gevolgen voor een gemeenschappelijke visievorming of wilsvorming, maar ook daar 
houden de opdrachtgevers 'hun handen vrij'. In geen van de casus leidt de verkenning tot een gemeenschappelijk convenant of anderszins. De resultaten worden meegenomen in het eigen beleidsproces en in de hoofden van de deelnemers. De meeste opdrachtgevers lijken de mening toegedaan dat het al moeilijk genoeg is om intern commitment te krijgen. Het idee van gemeenschappelijke resultaten met andere organisaties, laat staan gemeenschappelijk opdrachtgeverschap, lijkt een brug te ver.

\subsection{HET OPDRACHTNEMERSCHAP}

Verkenningen worden veelal uitgevoerd door enthousiaste medewerkers van een organisatie - soms aangevuld met externe verkenners/onderzoekers. Vaak hebben ze de ambitie iets nieuws en anders te doen. Veelal gaat het hierbij om beleidsmakers met interesse voor de toekomst en een kritische houding aangaande de waan van de dag die veel beleidsprocessen lijkt te sturen. Deze beleidsmakers nemen een reflexieve houding aan en zijn in staat tot een creatieve aanpak.

Vervolgens trekken ze onderzoekers aan om de fact finding te verzorgen en activeren zij andere beleidsambtenaren en experts om denkbare en wenselijke toekomstbeelden te genereren. Daarbij wordt vrij eclectisch omgegaan met trendstudies en ander "feitenmateriaal". De meeste aandacht gaat uit naar toekomstbeelden op het raakvlak van het waarschijnlijke (ondersteund door de feiten) en het wenselijke. Dit lijkt zelfs het geval bij de Natuurverkenningen, terwijl juist daar het leeuwendeel van de verkenningsinspanningen betrekking heeft op het verzamelen van gegeven over de fysieke werkelijkheid (bomen, planten enz.).

Het kan een succesfactor zijn voor beleidsinnovatie als er afstand is tot bestaand beleid. Het kan ook een succesfactor zijn als er concurrentie is tussen opdrachtnemers. Immers juist daar waar de toekomst onkenbaar is en verkenningen veelal zijn gebaseerd op extrapolaties (lees lessen uit het verleden) en verbeeldingen (zowel in roze als in zwarte kleuren), leidt de concurrentie tussen ontworpen toekomsten, en daarmee ook de mogelijkheid tot vergelijking, tot meer kennis over deze toekomst dan in geval van een dominante verkenning door een zogenaamde kennismonopolist. Uiteraard doet zich hier wel het probleem voor dat het hiervoor benodigde open debat zich slecht verdraagt met de dagelijkse strijd om beleid, waar reductie van variëteit (ook wel genoemd alle neuzen dezelfde kant op) een manier is om eenheid in het beleid te krijgen en om 'krachtig' beleid te voeren.

De opdrachtnemers leren het meeste van de verkenningen en zijn regelmatig teleurgesteld over de benutting van de verkenningen door anderen. Kennis in hoofden beklijft het beste. Doordat besluitvormers, bestuurders en politici vaak niet deelnemen aan de verkenningstrajecten, lijken zij het minste op te steken van de verzamelde kennis. Na afronding van de verkenningen verdwijnen veel van de verkenners uit de daarop volgende beleidsprocessen. Mede door deze discontinu- 
iteit worden al ras weer nieuwe pogingen gedaan door de nieuwe lichting beleidsmakers om kennis te verzamelen die nuttig is in hun beleidsproces. Pregnant komt dat naar voren bij Nederland 2030. Alle betrokkenen zijn nu niet meer verantwoordelijk voor het schrijven van de vijfde nota ruimtelijke ordening.

\subsection{HET TRAJECT VAN TOEKOMSTVERKENNING}

Verkenningen worden vaak 'gewoon gestart'. Soms gaat het om normal procedures waar de verkenners redelijk (denken te) weten wat verwacht wordt (Natuurverkenningen), maar meestal gaat het om eenmalige trajecten waar de betrokkenen stap voor stap beslissingen nemen over de daarop volgende stap. In een aantal gevallen was in aanvang wel een procesontwerp en een communicatieplan aanwezig, zoals bij Nederland 2030 en Brabant Manifest, maar ook daar krijgen de vervolgstappen op de tast vorm. De (beleids-)omgeving noopt tot aanpassing.

In de verkenningstrajecten zijn met regelmaat buig- en knikpunten waar te nemen, waarop de richting van de verkenning verandert. Soms komen de koerswijzigingen voort uit keuzen van de verkenners, maar met regelmaat vinden ook externe interventies plaats, met name uit de beleidswereld. Dit komt naar voren bij Nederland 2030, waar de standpuntbepaling van de minister het denken over beleid dat afwijkt van het bestaande beleid sterk inperkte. Overigens bedoelde zij dit ook te bereiken. Bovendien leidde de komst van een nieuwe minister en het verdwijnen van de verkenners uit het vervolgtraject tot een nieuwe agenda en daarmee tot nieuw onderzoek.

Het belangrijkste dilemma is hoe wensbeelden, trends en denkbeelden met elkaar te combineren. In Nederland 2030 zijn ze gedurende het proces door elkaar heen gaan lopen. In de Natuurverkenningen lijkt een sterke scheiding te bestaan, waarbij de verkenningen zich richten op trends. Maar ook daar blijkt dat de onderzoekers wensbeelden inbrengen en verwachtingen over beleid(successen) meenemen. Ook Questa worstelt sterk met dit vraagstuk. Eerst gaat het vooral om denkbare toekomsten, maar later moeten er onder druk van beleidsmakers toch weer feiten en wensen ingebracht worden. Bij ons bestaat het beeld dat met name scenario's waar de drie (onbewust) door elkaar heen gebruikt worden minder bruikbaar zijn voor beleidsprocessen.

\subsection{DE ORGANISATIE VAN DE OVERDRACHT}

De overdracht van de verkenningen is over het algemeen niet geregeld. Soms wordt de overdracht vorm gegeven door de overhandiging van één of meer rapporten (Natuurverkenningen en Brabant 2050) en wachten te verkenners verder af of beginnen zij aan een nieuwe opdracht. 
Bij verkenningen waar de ambitie verder reikt dan het vaststellen van de feiten, blijkt het moeilijk om dat wat geleerd is in verkenningen over te dragen aan degenen die, in een organisatie en van de opdrachtgevers, niet nauw betrokken waren bij het verkenningenproces. Meestal neemt de opdrachtgever daarvoor ook geen, of weinig, tijd en heeft de opdrachtnemer weinig tijd ingeruimd om hier nog aan te werken. Met name bij Natuurverkenningen 97 en Nederland 2030 was dit het geval.

Het lijkt er soms ook op dat de opdrachtnemer wel blij is 'dat het eindelijk is afgelopen'. Hij verlangt naar iets nieuws. In het geval Questa heeft de opdrachtnemer geprobeerd om op basis van de scenario's nog een aangepast product te leveren, om het gebruik door andere beleidsmakers te vergemakkelijken. Bij de Scenario's is de overdracht vooral tijdens het proces verlopen en dat was ook de voornaamste inzet. Ook in de Woonverkenningen lag een groot deel van de overdracht tijdens het proces en niet daarna. In het traject van Brabant 2050 is de overdracht steeds belangrijker geworden in de loop van het traject. De scenario's waren in eerste instantie 'gedropt' maar er is later een discussieronde met veel bijeenkomsten en 'verrassende ontmoetingen' aan toegevoegd.

We menen te mogen concluderen dat er behoorlijk wat kennis verloren gaat voor het beleidstraject bij de afronding van de verkenning. De vraag is, of hier niet iets aan gedaan moet en kan worden. Juist waar het omgevingsbeleid te maken heeft met steeds meer en omvangrijkere claims op een min of meer constante hoeveelheid ruimte en milieu, lijkt het gewenst het kennisniveau van alle betrokkenen over de complexe interactie tussen wonen, werken, logistiek, recreatie en andere functies op te voeren.

\subsection{BENUTIING VAN DE RESULTATEN VAN DE TOEKOMSTVERKENNING}

Dat de verkenners leren van hun verkenning is een goede zaak. Als deze personen vervolgens niet behouden blijven voor de organisatie en voor vervolgtrajecten, valt de benutting van kennis tegen. Wanneer de bestuurlijke opdrachtgever sterk betrokken is geweest bij de verkenning, zoals in Brabant, en ook een rol blijft spelen in vervolgtrajecten, dan kan een aanzienlijk deel van de kennis worden bewaard, benut en verrijkt. In alle andere gevallen verdwijnen veel van de creatieve invallen, consistente beelden en voorspellende gedachten geheel of deels weer uit beeld.

We achten het niet uitgesloten dat verkenningen beter benut worden wanneer ze, sterker dan nu het geval is, gekoppeld worden aan bijbehorende beleidsprojecten. De verkenning kan een permanente reflectie op het beleidsproject leveren. Met name op rijksniveau is dan echter wel een verandering nodig in het denken over het voeren van beleid. Politieke gezagsdragers lijkt er veel aan gelegen om hun beleidsprojecten zoveel mogelijk te fixeren. Illustratief is bijvoorbeeld de uitspraak van de minister van Verkeer en Waterstaat dat het MIT in beton gegoten is. Ze zegt 
daarmee dat de projecten waartoe enige jaren geleden is besloten uitgevoerd moeten worden, zelfs als kennis van de toekomst aanleiding zou kunnen geven om andere projecten meer naar voren te schuiven. Het is de vraag of deze angst voor flexibiliteit wijs is.

\subsection{AFSLUITENDE OPMERKINGEN}

Het verkennen van de toekomst is een belangrijke activiteit in het openbaar bestuur. Er wordt veel tijd en creativiteit in geinnvesteerd. In toenemende mate raken de verkenningen vervlochten met processen van organisatieontwikkeling en interactieve beleidsvorming. Vaak zijn de te leveren resultaten onderdeel van het verkenningstraject zelf en zijn ze allerminst eenduidig. We hebben de indruk dat verkenningen gelijktijdig te dicht bij het beleid staan, waardoor ze onvoldoende een kritische reflectie op dat beleid kunnen geven omdat daarmee een bewindspersoon in de problemen kan worden gebracht, en te ver afstaan van het beleid als het gaat om de benutting van de verkregen inzichten. Vele malen kregen we te horen dat de verkenners geleerd hebben van de verkenning en dat deze vervolgens niet of nauwelijks deelnamen aan de vervolgtrajecten.

Ook is het onze indruk dat verkenningen meer gebruikt worden om de positie van een organisatie te versterken dan om de samenwerking met andere overheden te bevorderen. We constateren hier een verschil met de private sector en kunnen ons niet aan de indruk onttrekken dat ook de diverse onderdelen van de overheid, naar functie en schaal onderscheiden, allen veel baat hebben bij processen van gezamenlijke toekomstverkenning en benutting. De effectiviteit van beleidsinspanningen en de rol van de politiek zouden er beide door versterkt kunnen worden. Maar deze gedachte lijkt niet te domineren in bestuurlijk Nederland. 


\section{NOTEN}

1 Misschien is een ander verschil met het bedrijfsleven wel dat verkenning daar een vorm van risicobeheersing is Een toets op de robuustheid van het te leveren product loont in het bedrijfsleven. Politieke successen daarentegen worden niet gerealiseerd door wijs lange termijnbeleid, maar door overtuiging en draagvlak en daar worden gewenste effecten nu eenmaal onontkoombaar overbelicht en de ongewenste effecten verdoezeld. 


\section{EPILOOG}

De ex-postevaluatie van de toekomstverkenningen is een tussenstap in het traject dat de Stuurgroep Toekomstonderzoek en strategisch Omgevingsbeleid uitgezet heeft voor haar bestaansperiode. De Stuurgroep T\&o is een ontmoetingsplaats van twee werelden: het toekomstonderzoek (de WRR en de sectorraden) en de wereld van het strategisch beleid (de departementen). De Stuurgroep stelt zich de vraag of de effectiviteit van het toekomstonderzoek (lange termijn informatie) in het strategisch omgevingsbeleid (korte termijn beslissingen) verhoogd kan worden. Het traject dat de Stuurgroep zich heeft voorgenomen verloopt via een tweetal sporen: onderzoek en interactie.

De ex-postevaluatie, die betrekking heeft op de toekomstverkenningen uit de tweede helft van de jaren ' 90 , is een eerste stap in de reflectie op de verbindingen tussen deze twee werelden. De verkenningen uit deze periode kunnen worden opgevat als een nieuwe generatie, die in meerdere opzichten afwijkt van de vorige.

Allereerst mag het verkennen van de toekomst zich verheugen in een toenemende populariteit. Niet alleen de departementen gaan ertoe over in steeds kortere cycli verkenningen en beleidsnota's op elkaar te laten volgen, ook de andere bestuurslagen laten zich niet onbetuigd. Na de Provincies en de grote steden, volgen nu ook de middelgrote steden. Het toekomstdebat is dalend cultuurgoed: met de democratisering en toenemende deelname verschuiven de standaardeisen. De wetenschappelijke fundering telt minder zwaar dan bruikbaarheid en gebruikersvriendelijkheid. De weerstand van onderzoekers hiertegen neemt af met het besef dat ook de wetenschap geen harde feiten over de toekomst op tafel kan leggen.

Toekomstverkenningen zijn in afnemende mate een doel in zichzelf. Bestuurders en beleidsmakers kunnen ook om heel andere redenen dan nieuwsgierigheid naar de toekomst een verkenning organiseren. Het vergroten van betrokkenheid van burgers bij de politieke besluitvorming, het verweven van draagvlak voor beleid, het vergroten van het lerend vermogen bij de ambtelijke organisatie of het creëren van politieke manoeuvreerruimte kunnen evenzo goede redenen zijn voor een groots opgezette toekomstverkenning. Deze verschijnselen doen zich niet alleen voor bij lokale of regionale overheden. Het voorliggende onderzoek geeft treffende voorbeelden van serieuze toekomstverkenningen op Provinciaal of rijksniveau waarin een mix van deze motieven voor de opdrachtgever een rol heeft gespeeld.

De popularisering van het fenomeen toekomstverkenning duidt ook op een toenemend besef van de onzekere ontwikkelingen van de omgeving en de behoefte bij de beleidsmakers om te leren omgaan met dynamiek en complexiteit. Onzekerheden kunnen aanleiding geven tot alleriei verschillende behoeften bij de beleidsmakers. De een zal trachten de onzekerheid te verminderen door middels onderzoek het beleid een legitimiteit te verschaffen. De ander zal trachten de onzekerheden zichtbaar te maken om het voorgenomen beleid te testen. De derde zal het 
delen van onzekerheden met anderen opvatten als een interactief leerproces voor het opstellen van een gezamenlijke strategie met andere actoren.

De toekomstverkenning wordt in toenemende mate ingezet voor andere doelen en dat blijft niet zonder gevolgen voor het proces waarbinnen zij gestalte krijgt en voor de gehanteerde methodologie.

De ex-postevaluatie maakt zichtbaar dat de kwaliteit van een toekomstverkenning niet beoordeeld kan worden los van de context waarin deze gestalte krijgt. Anders geformuleerd: er is alle aanleiding tot zorg met betrekking tot de kwaliteit van toekomstverkenningen, maar deze kan niet worden weggenomen door herijking van de wetenschappelijke maatstaven alleen. De relatie tot het beleidsproces, de schaal en de beleidsoriëntatie van de opdrachtgever zijn zeker zo belangrijk. De vergelijking van de zes departementale en provinciale toekomstverkenningen maakt duidelijk dat de percepties van de opdrachtgever in verschillende fasen van de verkenningen en de wijze waarop beleid en verkenning wel of niet met elkaar vervlochten zijn, sterk doorwerken in de methodologie en de kwaliteit van de verkenning.

In vergelijking tot de vorige generatie toekomstonderzoek laat het zestal uit de negentiger jaren een tweetal opmerkelijke verschillen zien. Het eerste is dat onderzoek zich niet langer beperkt tot de kennis van de feiten, maar zich uitstrekt over de terreinen van het mogelijke en het wenselijke. Het tweede verschil betreft de verschuiving in de opvatting over de sturingsvraag in de netwerksamenleving. De ex-postevaluatie heeft zich op de eerste van de twee verschuivingen geconcentreerd. Er is voor de werelden van beleid en toekomstonderzoek alle aanleiding tot reflectie op ervaringen met de verschuivingen die in het afgelopen decennium hebben plaatsgevonden.

Alvorens het onderzoekstraject te vervolgen, met een analyse van lopende projecten waarin getracht zal worden tot optimaliseringen te komen, is het van belang de beide werelden in staat te stellen om met elkaar in dialoog te treden. De expostevaluatie heeft veel aandacht voor de vervlechting én ontvlechting van willen, weten en kunnen. Met deze invalshoek wordt gekeken naar de relaties tussen opdrachtnemers en opdrachtgevers en naar de dynamiek die zich in de verkenningen ontwikkelt. De netwerkbenadering geeft alle aanleiding om de nieuwe generatie toekomstverkenningen juist met deze ogen te bekijken. De relevantie van deze benadering voor het paradigmadebat in de nieuwe generatie verkenningen kan goed worden geillustreerd aan de hand van de volgende vier observaties.

Het eerste betreft de beleidsoriëntatie waarmee een toekomstverkenning wordt gestart. In sommige gevallen wordt een toekomstverkenning geīnitieerd met de uitdrukkelijke bedoeling te komen tot beleidsinnovatie, in andere gevallen zijn de intenties veel diffuser. Soms wordt een verkenning geëntameerd om daarmee te voorzien in de behoefte aan nieuwe verhoudingen in de sector (wonen), soms om 
de betreffende politieke opdrachtgever meer manoeuvreerruimte te verschaffen. Er zijn ook verkenningen die uitsluitend dienen als beleidslegitimatie en herbevestiging van het beleid. Ook komt het voor dat intenties in de loop van de tijd veranderen en daarmee ook de verkenning in een andere richting wordt gemanoeuvreerd. De positionering van de toekomstverkenningen en de wijze waarop de verhouding tussen opdrachtnemer en opdrachtgever wordt vormgegeven hebben alles te maken met deze beleidsoriëntaties en de verschuivingen die daarin al dan niet optreden.

Op welke manier kunnen toekomstverkenningen bijdragen tot een permanente reflectie en verrijking van het beleidstraject zonder de uitvoering van bestaand beleid voor de voeten te lopen?

Een tweede punt betreft de methodologische vernieuwing die zich heeft voltrokken in de verkenningen. In de 'hype' van de toekomstverkenningen heeft het gebruik van de 'scenariomethode' een grote vlucht genomen. Het begrip scenario wordt te pas en te onpas gebruikt. De erkenning dat het onderzoek zich niet langer kan beperken tot toetsing van beleidsopties van slechts één actor (de overheid) en dat wensen van andere actoren zeker zo relevant zijn voor de realisering van beleidsopties van de overheid, heeft een verschuiving in het onderzoek naar de feiten tot verkenning van willen, weten en kunnen tot gevolg gehad. Op de vraag welke methodologie daarbij zou moeten worden gehanteerd is slechts in enkele gevallen getracht een systematisch antwoord te geven. Op de methodologie en het proces van de scenariomethodiek als vorm van toekomstverkenning in een multi-actor samenleving heeft nog weinig reflectie plaatsgevonden. Het resultaat daarvan is dat optredende breuken in de beleidsoriëntatie of veranderingen in de procesgang niet worden gerepareerd. Zou het inbouwen van een onafhankelijke reflectiefunctie in de toekomstverkenningen tegemoet kunnen komen aan enerzijds de behoefte aan flexibiliteit en anderzijds aan methodische helderheid?

Een derde observatie betreft de korte houdbaarheidstermijn van de resultaten van verkenningen in de overheidsorganisatie. Soms zijn de resultaten niet direct zichtbaar en werken ze pas op langere termijn effect door, maar veelal ontbreekt continuiteit in de kennisproductie. De resultaten van de verkenningen worden veelal door de beleidsmakers die er mee zouden moeten werken niet gekend. Er is geen overdracht van de ene fase naar de volgende fase, maar er is zelfs vaak geen behoefte om op de schouders van reeds aanwezige kennis te gaan staan. Het vernieuwingspotentieel dat voortkomt uit een toekomstverkenning wordt niet benut aangezien het lerend vermogen van de organisatie als geheel en het collectief geheugen slecht ontwikkeld zijn. Waar de kennisfunctie niet een zekere onafhankelijkheid van het beleid heeft verworven en niet in staat is tot kenniscumulatie hoeft men zich te verwonderen dat beleidscontinuiteit in de programmering van onderzoek de doorslag geeft en telkens repeterende vragen stelt. Als de kennisfunctie wel een zekere autonomie heeft is de kans op continuïteit in de kennis groter, maar het lerend vermogen nog lang niet gegarandeerd. Hier ligt voor de sectorraden en de WRR een interessante vraag: op welke wijze kan in de netwerk- 
maatschappij collectief geheugen effectief gemaakt worden en hoe kan het leervermogen (strategisch denken) van de actoren betrokken bij het omgevingsbeleid worden verhoogd?

De vierde observatie betreft het niet bij elkaar komen van de verwachtingen van opdrachtnemers en opdrachtgevers over de aard van de resultaten van toekomstverkenningen. De onderzoekers brengen onzekerheden in de toekomstige ontwikkeling aan het licht en kunnen daarmee het beleid behoeden voor de gedachte dat wat gisteren goed was, morgen ook goed zal zijn. De voorspellingen over de economische ontwikkelingen waarmee deze kabinetsperiode gestart is, blijken binnen twee jaar $100 \%$ te laag te zijn.

De opdrachtgever, de bestuurder, wil onzekerheidsreductie en feiten om daarop het beleid te kunnen baseren. De criteria voor de bruikbaarheid van een toekomstverkenning worden door de opdrachtgever ontleend aan de beleidscontext en de behoefte aan onzekerheidsreductie. Een voorbeeld hiervan is de beleidsvereiste: economische omgevingsscenario's van het CPB te gebruiken als kader voor de toekomstverkenning van beleidssectoren. Het resultaat daarvan kan niet anders zijn dan dat het sectorbeleid geen enkel effect heeft.

Hier ligt een wezenlijk communicatievraag voor onderzoeksinstellingen: hoe breng je onzekerheden op een effectieve manier onzekerheid over aan politici?

Uit deze epiloog kunnen een aantal agendapunten worden geformuleerd ter bespreking in het interactiespoor van de werelden van onderzoek en beleid:

1 Hoe kan de rol van de opdrachtgever leiden tot duidelijke keuze over de positionering van de verkenning en hoe kan daarbij de reflectie op het bestaande beleid gestalte krijgen en leiden tot een verrijking van het beleidstraject?

2 Hoe kan de reflectie op de methode binnen een toekomstverkenning, waarin procesinterventies en opdrachtverschuivingen plaatsvinden, gehandhaafd worden?

3 Hoe kan kennisproductie en -overdracht de actoren in staat stellen tot strategische interactie?

4 Hoe kan het lerend vermogen en het collectief geheugen in omgevingsbeleid versterkt worden? 


\section{DEEL II}

\section{HET INTERACTIESPOOR}

VERSLAG CONFERENTIE "TERUGBLIK OP TOEKOMSTVERKENNINGEN" STUURGROEP TOEKOMSTONDERZOEK EN OMGEVINGSBELEID

24 MAART 13:30 - 18:00 UUR 


\section{DAGINLEIDINGEN}

\subsection{INLEIDING DOOR PROF.DR.IR J. BOUMA, VOORZITTER VAN DE STUURGROEP}

Middels de instelling van de Stuurgroep Toekomstonderzoek en strategisch Omgevingsbeleid ( $\mathrm{T} \& \mathrm{O}$ ) is in juni 1999 gevolg gegeven aan een van de belangrijkste aanbevelingen van de commissie Infrastructuur Toekomstonderzoek Landelijk en Stedelijk Gebied (in de wandeling de cie. Van den Ban). De aanbeveling luidde: "Voor het verdergaand optimaliseren van de interactie tussen beleid en onderzoek, achten wij het van veel belang, dat de door ons gestarte open dialoog tussen beide subsystemen in de toekomst wordt voortgezet. Bij deze dialoog dienen het bedrijfsleven en de politiek nadrukkelijker te worden betrokken, dan in onze werkperiode het geval was."

Nadat de opdrachtgevers van de commissie, de NRLO, de NRO en de RMNO deze aanbeveling al bij de aanbieding van het eindrapport hadden overgenomen, heeft vervolgens de WRR zich bereid getoond haar platformfunctie voor het toekomstonderzoek in Nederland vorm te geven middels de instelling van de Stuurgroep T\&O. De sectorraden, vertegenwoordigd in het cos hebben zich financieel gecommitteerd aan het project. Het project heeft een looptijd van twee jaar en de volgende doelstelling: 'Het project T\&O stelt zich ten doel om in een leertraject ervaringen op te doen met het interactief ontwikkelen en uitvoeren van toekomstonderzoek ten dienste van het beleid ter zake.' Het gaat daarbij vooral om het achterhalen van manieren van werken en het ontwikkelen van in brede zin toe te passen technieken die tegemoet komen aan de wens om de geconstateerde kloof tussen toekomstonderzoek en omgevingsbeleid te helpen overbruggen.

Tijdens deze conferentie wordt de interactie met $\mathrm{u}$ als betrokkenen bij verleden verkenningen aangegaan met daarbij het discussiestuk in de hand dat door Bestad en De Stad B.v. in opdracht van de stuurgroep is gemaakt, en plenair geintroduceerd wordt door prof.dr.ing. Teisman.

De doelen van deze dag zijn:

1 Het formuleren van leerervaringen, opgedaan in zes toekomstverkenningen in het kader van strategische besluitvorming rond het omgevingsbeleid (op basis van de zes ex-poststudies).

2 Het formuleren van concrete aanbevelingen voor toekomstonderzoek die de kwaliteit en de efficiëntie van strategische beleidsvorming kunnen verhogen (o.a. ten behoeve van de ex-antestudies in het T\&O project).

In de discussies in de werkgroepen die op het plenaire gedeelte volgen, worden de ex-poststudies per casus besproken op basis van stellingen rond drie thema's:

- vervlechting en ontvlechting van beleid en onderzoek;

- organisatie en procesbewaking;

- omgaan met onvoorziene maar onontkoombare interventies. 
$\mathrm{Na}$ afloop van de werkgroepdiscussies zal er een plenaire afsluiting zijn met een panel met opdrachtnemers van afgelopen verkenningen.

\subsection{PROF.DR.ING. G.R. TEISMAN GEEFT EEN INLEIDING BIJ HET DISCUSSIESTUK 'TERUGBLIK OP TOEKOMSTVERKENNINGEN'}

\subsubsection{INLEIDING}

Op het brede terrein van het omgevingsbeleid hebben verschillende overheden de afgelopen jaren toekomstonderzoek laten verrichten. De nieuwe 'generatie' verkenningen tracht recht te doen aan veranderde maatschappelijke omstandigheden en nieuwe inzichten. De samenleving is meer complex geworden, meer dynamisch, minder goed te kennen. En mede daarom neemt de kans toe dat beleid zijn doel mist. Bijvoorbeeld omdat het zich nog richt op het oude doel, daar waar de maatschappij zich al beweegt in een nieuwe richting, of omdat het zich baseert op empirische veronderstellingen die al gedurende het beleidsproces gelogenstraft worden. Of omdat het instrumenten inzet, die draagvlak ontberen en onvoorziene of ongewenst, of in de meest slechte situatie, onvoorziene en ongewenste effecten hebben.

Om deze bekende uitingen van falend beleid te attaqueren, is er behoefte aan strategisch beleid. Strategisch beleid onderscheidt zich op een aantal punten van "gewoon" beleid. Het dient meer toekomstgericht te zijn en het dient meer reflexief te zijn. De reflexiviteit heeft daarbij betrekking op drie vragen:

$1 \quad$ Kloppen de doelstellingen van het gevoerde beleid?

2 Kloppen de feiten waarop het beleid is geschraagd met de feiten zoals deze zich aan ons voor doen?

3 Passen de gehanteerde beleidsmethoden?

Om antwoord te kunnen geven op de drie vragen, dienen verkenningen te worden uitgevoerd. De vraag is dan natuurlijk hoe geslaagde verkenningen uit te voeren. Deze vraag staat vandaag centraal.

Om een begin van een antwoord te geven, is de terugblik tot stand gebracht. Daarin wordt letterlijk teruggeblikt op een aantal verkenningen op het terrein van strategisch omgevingsbeleid. We beschouwen ze als indicatief voor de manier waarop het openbaar bestuur het strategisch omgevingsbeleid poogt te onderbouwen en vorm te geven.

In de Terugblik gaan we met name in op de vraag hoe de verkenningen en de strategische beleidsontwikkeling zich tot elkaar verhouden. De verhouding tussen de twee is al niet gemakkelijk, en zal mogelijk nog wel eens veel problematischer kunnen worden.

Zo bestaat er een groeiende twijfel over de waarde van voorspellingen in een dynamische samenleving. Zelfs de economische groei van volgend jaar kan slechts met een foutmarge van vele tientallen procenten worden gegeven. Heeft het dan nog 
wel zin om te onderzoeken hoe de groei van de mobiliteit zich zal ontwikkelen over de komende 10 jaar, of hoe de ruimteconsumptie in 2020 of 2030 eruit zal zien.

Kunnen we door intellectueel hoogstaande bijdragen van gerenommeerde onderzoekers en verkenners, de feiten nog wel achterhalen? Is objectief vaststelbaar wat het ruimtegebrek in de Rotterdamse haven is? Bestaat het broeikaseffect of is het een gedachtespinsel? Nu nog hanteert het Kabinet een organisatieprincipe voor besluitvorming over grote ruimtelijke projecten waar eerst nut- en noodzaak moet worden vastgesteld, waarna vervolgens ingegaan kan worden op de verdere vormgeving van dat project. De vraag is of deze ordening vol te houden is. Het Kabinetsbesluit over mainport Rotterdam, nadat de nut- en noodzaakdiscussie was afgerond, laat zien dat hierover gerede twijfel kan bestaan. We lijken het nauwelijks nog eens te worden over de feiten. Ook de latere beslissingen, zoals het niet verder verkennen van de oplossing Zuidwest Nederland, lijkt eerder te berusten op de behoefte aan besluitvaardigheid dan op de empirische constatering dat deze oplossing onderdoet voor de twee andere.

\section{Terzljde}

Deze behoefte aan besluitvaardigheid is overigens wel een belangrijke factor in strategische beleidsontwikkeling. Deze neemt nog steeds de vorm aan van reductie van variëteit. Een beleidsmaker die meer opties openhoudt, vanuit de waarneming dat de samenleving zich snel ontwikkelt en dat een flexibele respons op deze dynamiek ook vereist dat meerdere oplossingsrichtingen gelijktijdig worden bewandeld, krijgt al gauw het predikaat van besluiteloze twijfelaar. Besluiten is doen, zichtbare resultaten binnen de termijn van vier jaar. Dat zal ook zo blijven. En de twijfel over de feiten zal eveneens blijven bestaan. En toch is het ook hoogst ombevredigend om te stoppen met verkenningen. Daarmee zou het bestaande beleid de norm der dingen worden en de kans op slechte beleidsresultaten zeker niet verminderen. Kortom, we moeten iets met verkennen, maar we weten niet zeker wat.

Het is vanuit dit dilemma dat de terugblik is uitgevoerd. De terugblik behandelt zes casus:

1 Brabant 2050 en Scenario's voor landbouw en ruimtegebruik Brabant;

2 Natuurverkenningen;

3 Nederland 2030, de verkenning van ruimtelijke ontwikkelingen;

4 Questa;

5 Woonverkenningen.

\subsubsection{AFBAKENING VAN HET ONDERZOEKSOBJECT}

Toen de terugblik werd aangevangen, stonden we voor de vraag waar naar te kijken. Een verkenning bestaat uit een groot aantal componenten. Een omvattende terugblik vereist al snel een enorme onderzoeksinspanning. Het was voor ons de 
vraag of zo'n inspanning zou renderen. We hebben uiteindelijk gekozen voor een redelijk omvattende, vooral op vergelijking gebaseerde analyse.

Om deze vergelijking te kunnen uitvoeren is een aantal keuzen gemaakt, mede in het licht van de theoretische uitgangspunten over de netwerksamenleving. We hadden ons kunnen richten op de verkenning als wetenschap. Elke verkenning is te beschouwen als een meer of minder geslaagde poging om toekomstige feiten boven tafel te krijgen. Het is dan mogelijk om elke verkenning en elk detail te analyseren in termen van de gehanteerde probleemstelling, conceptueel model en onderzoeksdesign, alsmede de manier van gegevens verzamelen. We hebben dat niet gedaan.

We hadden ons ook kunnen richten op de ontwikkeling van het strategisch beleid zelf, in zowel de normatieve dimensie van wat willen partijen nu eigenlijk, als in de instrumentele dimensie van hoe pakken ze de beleidsontwikkeling aan, bijvoorbeeld bij de directie strategie van elk der departementen, of bij de totstandkoming van een der nationale nota's. We hebben dat niet gedaan.

Wij hebben ervoor gekozen met name de interactie tussen de beleidsmakers en de verkenners in kaart te brengen. Onze keuze is ingegeven door de volgende veronderstellingen:

- We delen de waarneming eerder gedaan (o.m. de commissie o.l.v. Van der Ban en ook door stuurgroepleden), dat beleidsmakers en verkenners verschillende soorten rationaliteit hanteren in hun kijk op de werkelijkheid en de daar uit voortvloeiende handelingen (De metafoor van de verschillende brillen).

- We gaan er ook vanuit dat uit de verschillende rationaliteiten verklaringen zijn te distilleren voor een gebrekkig en matig gebruik van verkenningen in beleidsprocessen en twijfel over de bruikbaarheid van verkenningen bij beleidsmakers. Het is echter de vraag of het hanteerbaar maken van deze spanning te vinden is in een gedetailleerde bestudering van een van beide rationaliteiten.

- We gaan er vanuit dat de manier waarop beide werelden invulling geven aan hun interactie, de meeste informatie geeft op weg naar verbetering.

Uiteraard kunnen deze keuzen bekritiseerd worden. We hebben ook al enige kritiek mogen horen. Sommigen pleiten voor een meer expliciete aandacht voor de wetenschappelijke en methodische rationaliteit van de verkenning, in de hoop door verbeteringen daarin de bruikbaarheid en gebruik van verkenningen te vergroten. We steunen deze insteek, maar twijfelen of er een directe relatie bestaat tussen de rationaliteit en het gebruik van de verkenningen.

Anderen zijn de mening toegedaan dat de politieke en bestuurlijke rationaliteit een kernverklaring is voor waarom verkenningen eenzijdig en beperkt gebruikt worden. De redenering daarbij is dat beleidsmakers in een institutionele en cognitieve fuik zitten, die zo sterk is dat ook een goed ontworpen verkenningsproces tot mislukken gedoemd is. Dat moge zo zijn, maar dan nog lijkt de meest begaanbare weg 
toch vooral in de interactie tussen verkenning en beleid te liggen. Daar ligt de kern van onze aandacht.

We hebben deze aandacht nader gespecificeerd door te kijken naar het rollenspel bij de verkenning en vervolgens te kijken naar hoe de interactie georganiseerd is. De volgende variabelen zijn daarbij onderscheiden. In termen van actoren maken we onderscheid tussen de volgende vijf rollen:

- Beleidsmatig actieve actoren die optreden als opdrachtgevers voor een toekomstverkenning. Is duidelijk wie de opdrachtgever is en namens wie deze handelt en vanuit welke behoefte?

- Opdrachtnemers die verantwoordelijk zijn (of zich voelen) voor kennisontwikkeling. Vaak zijn dit onderzoeks- of strategieafdelingen binnen ministeries, soms meer verzelfstandigde onderzoeksinstituten zoals RIVM en soms worden ook andere onderzoekers betrokken, maar dan veelal voor deeltaken.

- Interventieplegers die tussen start en beëindiging van een kennisontwikkelingtraject belangrijke interventies plegen in het betreffende traject (soms zijn dit opdrachtgevers, soms anderen)

- Beleidsmatig actieve actoren die optreden als ontvanger van de producten van toekomstverkenning, binnen de eerder geformuleerde verwachting dat deze ontvanger behoefte had aan de gegenereerde kennis.

- Alle actoren die waarneembaar gebruik maken van de producten van toekomstverkenning, ook als gebruik door deze actoren niet voorzien is door de opdrachtnemers en/of -gevers.

Verder wordt in de reconstructie gebruikt gemaakt van het begrip kennisproduct. We onderscheiden drie soorten kennisproducten:

- Geëxpliciteerde kennisbehoefte. In welke mate hebben de opdrachtgever en de opdrachtnemer in de aanvang van de verkenning expliciet interactie tot stand gebracht over de aard van de kennisbehoefte en is deze op enigerlei wijze vastgelegd.

- Tussentijdse kennisgenererende producten. Welke tussenproducten heeft de verkenning opgeleverd, tot welke reacties heeft dat geleid en in welke mate zijn mede hierdoor buigingen opgetreden in het verkenningstraject.

- Eindproducten waarmee de verkenning is afgesloten en die mogelijk als input dienen voor beleidsprocessen.

\section{Concreet leidt dat tot een reconstructie van:}

- Aanleiding tot en inhoud van het verkenningstraject.

Om een beeld te krijgen van de verkenning, wordt allereerst nagegaan waar de aanleiding lag en welk hoofdproduct de verkenning heeft opgeleverd.

- De aard en wijze van het opdrachtgeverschap.

De aard en de wijze van het opdrachtgeverschap, de mate waarin dit op schriftelijke wijze is vastgelegd, welke de verwachting was van de opdrachtgever.

- De invulling van het opdrachtnemerschap.

Nagegaan is of de onderzoekers zich bewust waren van de interactie tussen 
willen, weten en kunnen en van de rol die beleidsmakers aan hen hadden toegedacht. Gaat het de onderzoeker om factfinding, om de ontwikkeling van consistente normatieve modellen, of om denkbare toekomsten met een interne logica, die als referentiemodellen het beleidsproces faciliteren.

- Het verloop en de organisatie van het verkenningstraject.

Het verloop van de verkenning wordt in kaart gebracht om te verhelderen hoe de behoeften en interventies uit beleidsprocessen zijn verdisconteerd in de verkenning. We gaan na of er doelverschuiving plaats vindt in het onderzoekstraject en wat de gevolgen daarvan zijn voor de resultaten en het gebruik aan het eind van het onderzoekstraject.

- De overdrachtsregeling aan het eind van het onderzoekstraject. Is er een overdrachtsregeling en zijn verkenners en beleidspartijen zich bewust van de manier waarop ze kennis overgedragen. Gebruiken ze rapporten en beklijven deze. Benut men levende kennis (in de hoofden van participanten in het onderzoekstraject) en wordt deze kennis behouden in beleidstrajecten.

- Resultaten en benutting

Wat waren belangrijke resultaten van onderzoek (kennis in hoofden, die is ingezet in beleid; kennis in rapporten die daarna in de kast verdwenen of agendavormend werkten) en wie heeft er wat aan gehad. Ook bezien we waar kennis niet is benut, terwijl daar verwachtingen over waren.

\subsubsection{CONCLUSIES VAN DE TERUGBLIK}

Wat heeft de terugblik opgeleverd? Een aantal conclusies wil ik kort aanhalen:

- Verkennen van de toekomst is populair.

Vrijwel elke zich respecterende organisatie of eenheid lijkt bezig met een voor de eigen organisatie relevante toekomstverkenning. Een vraag is waarom elke organisatie een visie wil ontwikkelen, en met name waarom er geen samenwerking tussen overheden tot stand komt, daar waar ze grotendeels in dezelfde complexe en dynamische omgeving opereren. Opvallend is dat elke verkenning zijn eigen couleur locale heeft. De toekomst wordt geschetst in concepten en beelden van de (omgeving van de) beleidssector waarvoor de verkenning wordt gemaakt. De indruk bestaat dat daarmee ook een aanzienlijk deel van de sectorale beleidsovertuigingen wordt meegenomen. Daarmee wordt niet ontkend dat verkenningen worden ingezet om het 'willen' in de samenleving te achterhalen, zoals bij de Scenario's en het Manifest in Brabant, de Woonverkenningen en Nederland 2030 onder andere het doel was. Maar ook deze verkenningen kunnen zich niet geheel onttrekken aan de eigen logica van de organisatie en de sector.

$\mathrm{Er}$ is wel een bewustzijn dat verkenningen breder getrokken moeten worden. Bij aanvang wordt dit ook vaak uitgesproken. Gedurende het proces wordt de ambitie meestal teruggeschroefd. Is dat erg en is er iets aan te doen? Zijn verkenningen nu niet te sterk verbonden met positiebehoud en versterking van de opdrachtgevers? 
- Toekomstverkenningen als vervlechting van of verwarring tussen willen, weten en kunnen?

Wie zoekt naar strikt wetenschappelijk gefundeerde verkenningen in de klassieke traditie ('ontdek de feiten'), komt niet ver. Vaak gaat het om een combinatie van mogelijke, waarschijnlijke en wenselijke toekomstbeelden. Soms is er sprake van een tamelijk ondoordachte menging van kennis over trends, denkbare ontwikkelingen en wensbeelden. Aan u de vraag: wordt de onderscheiding in onvoldoende mate geproblematiseerd en bewaakt?

- Het opdrachtgeverschap blijkt nauwelijks eenduidig te omschrijven. Bij de rijksoverheid bestaan er lagen van opdrachtgevers, waardoor de communicatielijnen lang worden en verschillende interpretaties van de opdracht ontstaan. Er is regelmatig sprake van een gemengde opdrachtgevers/-nemersrol: men voegt een beetje eigen inzicht toe en voert een beetje uit. Tenslotte treedt veelvuldig een verandering op in opdrachtgever in persoon en rol gedurende de verkenning.

- Verkenners zijn eigen beleidsmedewerkers, aangevuld met externe onderzoekers.

Ze nemen een reflexieve houding aan en zijn in staat tot een creatieve aanpak. Vervolgens trekken ze onderzoekers aan om de factfinding te verzorgen en activeren zij andere beleidsambtenaren en experts om denkbare en wenselijke toekomstbeelden te genereren. Daarbij wordt vrij eclectisch omgegaan met trendstudies en ander 'feitenmateriaal'. De meeste aandacht gaat uit naar toekomstbeelden op het raakvlak van het waarschijnlijke (ondersteund door de feiten) en het wenselijke. Dit lijkt zelfs het geval bij de Natuurverkenningen, terwijl juist daar het leeuwendeel van de verkenningsinspanningen betrekking heeft op het verzamelen van gegevens over de fysieke werkelijkheid (bomen, planten, enz.).

- Verkenningen worden vaak 'gewoon gestart'.

Soms gaat het om normal procedures waar de verkenners redelijk (denken te) weten wat verwacht wordt (Natuurverkenningen), meestal om eenmalige trajecten waar de betrokkenen stap voor stap beslissingen nemen over de volgende stap.

In de verkenningstrajecten zijn met regelmaat buig- en knikpunten waar te nemen, waarop de richting van de verkenning verandert. Soms komen de koerswijzigingen voort uit keuzen van de verkenners, maar met regelmaat vinden ook externe interventies plaats met name uit de beleidswereld.

- De overdracht van de verkenningen is over het algemeen niet geregeld. Soms wordt de overdracht vorm gegeven door de overhandiging van éen of meer rapporten (Natuurverkenningen en Brabant 2050) en wachten de verkenners verder af, of beginnen zij aan een nieuwe opdracht.

Bij verkenningen waar de ambitie verder reikt dan het vaststellen van de feiten, blijkt het moeilijk om dat wat geleerd is in verkenningen over te dragen aan degenen die, in een organisatie en van de opdrachtgevers, niet nauw betrokken waren bij het verkenningenproces. Meestal neemt de opdrachtgever daarvoor ook geen, of weinig tijd, en heeft de opdrachtnemer weinig tijd 
ingeruimd om hier nog aan te werken. Met name bij Natuurverkenningen '97 en Nederland 2030 was dit het geval.

Het lijkt er soms ook op dat de opdrachtnemer wel blij is 'dat het eindelijk is afgelopen'. Hij verlangt naar iets nieuws.

Er gaat behoorlijk wat kennis verloren bij de afronding van de verkenning. De vraag is, of hier niet iets aan gedaan moet en kan worden. Juist daar waar het omgevingsbeleid te maken heeft met steeds meer en omvangrijkere claims op een min of meer constante hoeveelheid ruimte en milieu, lijkt het gewenst het kennisniveau van alle betrokkenen over de complexe interactie tussen wonen, werken, logistiek, recreatie en andere functies op te voeren.

- Vooral verkenners leren van hun verkenning.

Dat is mooi. Als deze personen vervolgens niet behouden blijven voor de organisatie en voor vervolgtrajecten, valt de benutting van kennis tegen. Wanneer de bestuurlijke opdrachtgever sterk betrokken is geweest bij de verkenning, zoals in Brabant, en ook een rol blijft spelen in vervolgtrajecten, dan kan een aanzienlijk deel van de kennis worden bewaard, benut en verrijkt. In alle andere gevallen verdwijnen veel van de creatieve invallen, consistente beelden en voorspellende gedachten geheel of deels weer uit beeld.

We achten het niet uitgesloten dat de verkenningen beter benut worden wanneer ze, sterker dan nu het geval is, gekoppeld worden aan bijbehorende beleidsprojecten. De verkenning kan een permanente reflectie op het beleidsproject leveren. Met name op rijksniveau is dan echter wel een verandering nodig in het denken over het voeren van beleid. Politieke gezagsdragers lijkt er veel aan gelegen om hun beleidsprojecten zoveel mogelijk te fixeren. Is dat zo, en wat moeten we er mee?

\subsubsection{DISCUSSIEPUNTEN}

Om deze redenen stellen we ons voor om de verkenningen vooral te bespreken in termen van drie kenmerkende begrippen /begrippenparen die horen bij interactie. Uiteraard is het ook van belang vast te stellen of hier de crux voor verbetering ook daadwerkelijk ligt:

1 Vervlechting en ontvlechting van verkenningstrajecten;

2 Organisatie en procesbewaking;

3 Omgaan met onvoorziene maar onontkoombare interventies.

Deze onderwerpen komen naar voren als de interactie tussen beide werelden wordt geproblematiseerd. Interactie komt tot stand in geval van wederzijdse afhankelijkheid. Geen der partijen is in staat om te domineren. Veel van dit soort ontwikkelingen wordt bediscussieerd onder de titel netwerkmaatschappij, beleidsnetwerken en zo verder. In deze studie wordt deze gedachtelijn ook gevolgd. 
Stel dat we op weg zijn naar een netwerksamenleving 'where nobody is in charge', wat betekent dat dan voor de relatie tussen weten, willen en kunnen. Drie eigenschappen zijn van belang:

- Meervoudige wilsbeschikking.

Er wordt veel gewild, op veel plekken en daar wordt op die plekken ook naar gehandeld. Professionals en onderzoekers kunnen niet meer gerust zijn over de vraag wat de maatschappij wil. Door de dynamiek in preferenties krijgt dat wat zij aanbieden (feiten en mogelijkheden) een grotere bederfelijkheid.

- Meervoudige werkelijkheid en de strijd om feiten.

Trends in de samenleving lijken zich steeds meer te ontrekken aan het vermogen van onderzoekers om ze vast te stellen. Feiten lijken steeds minder feiten. Er zijn tegenwoordig zoveel feiten. Hoe bepalen we de meest maatgevende feiten.

- Vluchtige en dynamische beelden van (on)mogelijkheden.

De vraag naar het kunnen is in een netwerksamenleving niet meer enkelvoudig te beantwoorden. Er zijn ketens en netwerken van handelingen die bepalen wat er gebeurt in een netwerksamenleving en daarmee wat er mogelijk is. In deze ketens dient de vraag zich aan wat anderen willen en welke interventies door nieuwe wilsbeschikkingen en nieuwe feiten de beelden van (on)mogelijkheden beïnvloeden.

Als minder eenduidig is wat gewild wordt, wat kan en wat is, wordt een dynamische interactie en samenwerking tussen politici, beleidsmakers en vorsers voor alle betrokkenen belangrijk. In de groepdiscussies zouden daarvoor een aantal handvatten kunnen worden aangereikt. 


\section{WERKGROEPDISCUSSIES}

\subsection{BRABANT 2050 EN SCENARIO'S VOOR LANDBOUW EN RUIMTEGEBRUIK}

$\begin{array}{ll}\text { Voorzitter: } & \text { Dhr. Verkaik (stuurgroep T\&O, NRLo) } \\ \text { Coreferenten: } & \text { Mw. Grijzen (vervangt Dhr. Broess, Provincie Noord-Brabant), } \\ & \text { Mw. Van Herwaarden (projectgroep Landbouw en Ruimte- } \\ & \text { gebruik in Noord-Brabant) } \\ \text { Verslag: } & \text { Mw. M. de Winter } \\ \text { Aanwezigen: } & \text { Dhr. De Kuijer (kDo Consultancy), Mw. Van Dam-Mieras (Open } \\ & \text { Universiteit, WRR), Dhr. Maessen (Provincie Noord-Brabant), } \\ & \text { Dhr. Thönissen (Kolpron), Dhr. Kroon (Alterra), Dhr. Cohen } \\ & \text { (promovendus onderzoek 'participating design'), Mw. Van Een- } \\ & \text { bergen (Projectleider van Brabant 2050), Dhr. Douw (LEI-DLO), } \\ & \text { Mw. Neven (Alterra/ DLO), Mw. Kenter (Nijenrode). }\end{array}$

\subsubsection{OPENING}

Verkaik opent de werkgroepbijeenkomst. Eerst worden de twee casus Brabant 2050 en Scenario's voor landbouw en ruimtegebruik door de direct betrokkenen gepresenteerd.

\subsubsection{CASUS 1: MANIFEST 2050}

Grijzen was als projectleider betrokken bij het opstellen van het Manifest 2050. De terminologie van vervlechting van 'willen', 'weten' en 'kunnen' in de 'Terugblik op toekomstverkenningen' spreekt haar bijzonder aan. Zij vertelt dat het Manifest is opgesteld naar aanleiding van discussies in het kader van de Nadere Uitwerking Brabantse Steden (NUBS). Het Manifest beoogde aanvankelijk om de sterke en zwakke punten in de samenwerking en communicatie op te sporen en verschillende maatschappelijke instellingen (kennisinstituten, bedrijfsleven) hier hun reflectie op te laten geven. Vanuit deze opzet is het uitgegroeid tot een agenda voor de toekomst van Brabant. De communicatie tussen bestuurders, sleutelpersonen uit maatschappelijke organisaties en het bedrijfsleven, beviel direct goed.

Bij het opstellen van het Manifest is er vanuit gegaan dat de toekomst meer is dan het opgeloste heden. Het 'willen', in de vorm van een visie, is nodig om op lange termijn vooruitgang te boeken.

Om deze reden zijn twee utopieën ontworpen. Vanuit droombeelden over Brabant over 50 jaar zou teruggekeken worden op de keuzen die in het heden gemaakt moeten worden om een beeld te realiseren. Aangezien er een groot afbreukrisico in zat, was het volgens Grijzen bijzonder dat de Provincie deze aanpak steunde. Van- 
uit de Provincie bekeken werd een soort 'Paard van Troje’ binnengehaald. Bestuurders kenden de inhoud van het Manifest niet en hadden er ook geen invloed op. Hun eigen werk zou ondermijnd kunnen worden.

In oktober 1997 is het Manifest aan de Provincie aangeboden als een middel om te communiceren met een breder publiek van Brabantse burgers. De noodzaak hiervoor is waarschijnlijk gerelateerd enerzijds aan de problematische planhorizon van vier jaar en anderzijds ook aan de verandering bij bestuurders. Die zijn, volgens Grijzen, tegenwoordig meer beroepspolitici en zoeken minder dan vroeger contact met de achterban. Zij komen meestal ook niet vanuit deze achterban naar voren.

\subsubsection{CASUS 2 SCENARIO'S VOOR LANDBOUW EN RUIMTEGEBRUIK IN NOORD-BRABANT}

Van Herwaarden was destijds vanuit de Provincie Brabant verantwoordelijk voor de landbouwverkenningen. Zij onderscheidt drie afzonderlijke trajecten:

1 de procesvoorbereiding in het bestuurlijke en ambtelijke traject;

2 de projectuitvoering in de onderzoeks-, maatschappelijke, bestuurlijke, en ambtelijke trajecten;

3 de projectoverdracht en evaluatie in het maatschappelijke-, bestuurlijke-, en ambtelijke traject.

Er zijn twee scenario's gemaakt: Onze Hof en Brabant Globaal. In de scenario's zijn maatschappelijke ontwikkelingen in beeld gebracht en de extremen zijn uitvergroot. Die zijn geconfronteerd met het heden, waarmee de grootste uitdagingen aan het licht zijn gebracht. De scenario's zijn gebruikt als discussiestukken en als middel om kansen en bedreigingen per scenario op te sporen. De link met beleid is gelegd door opties te formuleren. Die vertaalslag is stroef verlopen. Onder andere de actualiteit (de varkenspest) verminderde de aandacht voor de scenario's. Wel heeft het gedachtegoed van de scenario's doorgewerkt in meerdere strategische projecten. In een enkel geval was er meer sprake van een "telepathische overdracht", dan van een bewuste doorwerking.

Uit het laatste deel van haar betoog blijkt dat het gebrek aan een collectief geheugen binnen de Provincie, de persoonsgebondenheid en het niet 'onderhouden' van hetgeen reeds is bewerkstelligd als de zwaktepunten van dit project worden ervaren. Ook constateert zij dat in de landbouwverkenningen de ambtelijk betrokkenen een dubbelpositie hadden: als dagelijks bestuurders en als meedenkers over de toekomst los van de waan van de dag.

\subsubsection{STERKE EN ZWAKKE PUNTEN}

Van Eenbergen begint met positieve reflectie op de spin-off van het Manifest 2050. Er zijn met het Manifest veel nieuwe mensen bereikt buiten het vaste circuit. De 
Provincie bood ruim voldoende tijd om te reflecteren op het Manifest. Dat heeft een enorme rijkdom aan communicatie opgeleverd.

Een nadeel was dat er geen duidelijke doelstellingen waren, waardoor de inhoud van het Manifest en de discussies nogal breed uiteenliepen. Iedere participant had andere doelstellingen en invloeden. Dat bracht onduidelijkheid in de processen teweeg.

Grijzen sluit hierbij aan en noemt als negatief punt de gebrekkige interne communicatie bij de ambtelijke top. De betrokkenheid binnen de Provincie was er wel, maar het leek alsof de top (het management) niet geconfronteerd wilde worden met de visies van buitenaf.

Van Herwaarden noemt als positief punt dat de scenario's benut zijn als middel om interactieve beleidsvoering van buitenaf naar binnen te bewerkstelligen. Als negatief punt noemt zij dat de actualiteit is gaan domineren en het draagvlak voor de scenario's daardoor is afgenomen. Een tweede negatief punt is de discontinuiteit binnen de organisatie waardoor het leerproces binnen de organisatie bijna niet is beklijfd.

Van Dam-Mieras is positief over het 'losmakende' beeld van het Manifest: er is losgekomen van de waan van de dag. Ook is men door Brabant in Europees verband te plaatsen losgekomen van de 'gangbare' geografische schaal.

Kenter vindt dat er ook meer ruimte is gekomen in besluitvormingsprocessen omdat mensen in de gelegenheid zijn gesteld hier aan deel te nemen.

Maessen is positief over de provinciale schaal als niveau om dergelijke verkenningen op toe te passen.

Kroon vindt de doelgroep van agrariërs voor de landbouwverkenningen wel overzichtelijk maar vraagt zich ook af of de discussie wel voldoende integrerend is geweest. Douw geeft aan dat er wel geprobeerd is om de discussie te verbreden, maar dat andere groepen met een raakvlak aan de landbouw niet bij de discussie betrokken wilden raken. Thönissen is positief over het feit dat er relatie is gelegd tussen het product (de scenario's) en het maatschappelijke draagvlak hiervoor. Neven merkt op dat het politieke draagvlak juist niet voldoende is meegenomen. In de opzet van de scenario's en in de discussies achteraf had het politieke draagvlak meer betrokken moeten worden. Van Eenbergen is het hiermee eens en vindt dat het succes erg afhankelijk was van één persoon (Dhr. van Geel).

Een centrale vraag die voortkomt uit het rondje sterke en zwakke punten, is wat betreft de voorzitter Verkaik: "hoe kunnen bestuurlijke ambities behouden blijven als de aanjager verdwenen is?" Thönissen antwoordt dat de uitdaging uiteindelijk een structurele betrokkenheid van bestuurlijk ambtenaren, onderzoekers, management en burgers is. Die betrokkenheid is noodzakelijk voor de continuiteit van beleid gericht op toekomstverkenningen en voor een positieve uitwerking ervan. 
Neven stelt dat de methodiek van de toekomstverkenningen en de beleidsvisies met open vizier moeten worden vormgegeven, dus niet binnen een beperkte kring worden bepaald. Verkaik merkt hierover op dat het een grote kunst is om de noties, theorieën en methoden over toekomstverkenningen te combineren met het organische proces dat plaatsvindt door kennisuitwisseling tussen mensen. Neven is van mening dat een beleidstheorie ontwikkeld wordt rondom een probleem, niet rondom de mensen. Douw reageert hierop en stelt dat in de Landbouwverkenningen juist nadrukkelijk is gekozen om uit te gaan van de mensen. Het zwakke punt hierbij was de dubbelrol aan de kant van de opdrachtgever, die een spanning leverde tussen de planbureaufunctie en de beleidsfunctie. Dat werd vooral lastig in de fase van de vertaalslag van de scenario's naar de beleidsagenda. Ook interne spanningen tussen voor- en tegenstanders van het toekomstbeleid verzwakten de beleidsfunctie die juist nodig was om de beleidsagenda vorm te geven. Douw mist in de beschrijving van beide casus in de 'Terugblik op toekomstverkenningen' een uitleg over de manier waarop in de praktijk de verbanden tussen verschillende betrokkenen gelegd worden.

Neven is het ermee eens dat de betrokkenheid van verschillende actoren essentieel is voor de voortgang van het proces. De betrokkenheid moet gekoppeld worden aan het belang om te participeren.

Van Dam-Mieras vindt het jammer dat de ruimte (in tijd en geografie) die gecreëerd werd aan het begin van het proces sluipenderwijs weer lijkt te zijn verdwenen. Door de actualiteit zijn de tijd- en omgevingshorizon losgelaten, en zijn begrippen als duurzaamheid en het milieu toch weer onder druk komen te staan. Door een constante terugkoppeling van de referentiekaders van de toekomstverkenningen naar de actualiteit zou dit voorkomen kunnen worden. De Kuijer sluit hierbij aan en is van mening dat het ambtenarenapparaat al vanaf het begin van het verkenningenproces moet werken aan die brede visie, en niet pas wanneer het rapport er al ligt. Dat zou tot voordeel hebben dat er direct ruimte wordt gecreëerd om op een open manier aan een project te werken, en de werkwijze wordt sneller concreet binnen het ambtenarenapparaat. Grijzen merkt op dat inderdaad al in de eerste fase van het Manifest er meerdere projecten zijn gestart. De openheid en breedheid zijn al vroeg ontstaan en hebben vervolg gekregen.

Verkaik merkt op dat een vraag is welke kennis doorwerkt, bijvoorbeeld in het beleid van de Provincie, maar ook wat andere effecten waren, bijvoorbeeld de verzelfstandiging van maatschappelijke organisaties en gemeenten en nieuwe initiatieven. Ook is belangrijk geweest dat bewust gewerkt is aan de uitsplitsing van nieuwe initiatieven tijdens het proces van Brabant 2050 en dat deze ook (financieel) gevoed zijn. Er kan een onderscheid gemaakt worden tussen een vernieuwingsbeleid en een beheersbeleid. Door het Manifest zijn nieuwe kansen en problemen zichtbaar geworden en mensen geïnspireerd.

Kenter is van mening dat beleid vanuit een ander paradigma dan onderzoek opereert, respectievelijk een beheersconceptie en een meer innoverende aanname. 
Door met elkaar te reflecteren over aannames kunnen bottlenecks in de communicatie worden voorkomen. Verkaik sluit hierbij aan dat reflectie nodig is tijdens en na het proces, zowel intern door betrokkenen, als extern door anderen. Het leren tijdens het verkenningentraject is uitermate belangrijk.

Kenter heeft ook de indruk gekregen dat de verkenningenprocessen plaatsvinden naast de dagelijkse beleidspraktijk en dat ze nog geen onderdeel uitmaken van de dagelijkse praktijk. Grijzen reageert hier bevestigend op. Het begon als een samenwerking tussen de steden en onderweg is dat breder geworden.

Tot slot zijn er op de gele blaadjes een aantal opmerkingen gemaakt die niet allemaal in de discussie aan de orde zijn gekomen.

Het was niet voor iedereen duidelijk of het om de casus gezamenlijk ging of dat er één uitgelicht moest worden. De geeltjes geven hier dan ook geen duidelijkheid over. De bespreking van twee casus tegelijkertijd leverde een wat complexere discussie op, maar bracht ook aan het licht dat hetgeen in het ene geval een voordeel is in het andere geval ook een minpunt kan zijn.

Sterke punten:

- Ondanks de moeilijke organisatiegraad van de verkenningen hebben zij toch nog doorwerking gehad in het beleid.

- De provinciale schaal is overzichtelijk voor vervlechting en ontvlechting, zowel intern als extern.

- Het proces was Tosmakend', zowel in tijd (los van de waan van alledag) als geografisch (los van eigen schaalniveau, bijvoorbeeld alleen binnen de grenzen van de gemeente).

Zwakke punten:

- De provinciale rol is in ontwikkeling en de verkenning zou daar meer op gericht moeten zijn.

- Er is te weinig nagedacht over intern vervolg bij de Provincie: vasthouden van momenthum en mensen.

- Het ontbreekt aan collectief geheugen in de organisatie (de Provincie).

- Door het 'losmakende' beeld is er aan het begin wel aandacht voor duurzaamheid en milieu, maar gaandeweg versmalt het proces en gaat aandacht voor duurzaamheid verloren.

- De opdrachtgever moet meer verantwoording nemen voor het product en het proces, met het oog op de implementatie en het leereffect.

- Er is sprake van meerdere 'kampen': enerzijds beleid tegenover de verkenning, anderzijds bedrijfsvoering tegenover Research en Development. Er zou meer integratie van deze kampen moeten zijn. 


\subsection{NATUURVERKENNINGEN '97}

Voorzitter: Dhr. Bouma (stuurgroep T\&O, WRR)

Coreferenten: Dhr. Lammers (RrVM) en Dhr. Van der Klundert (LNV, dir. Natuurbeheer)

Verslag: $\quad$ Mw. Metze (projectsecretariaat)

Aanwezigen: Dhr. Oosterveld (RIVM), Mw. Van Asselt (ICIS), Dhr. Dammers (Alterra), Dhr. Hillebrand (LEI-DLO), Dhr. Vos (LNV strategie), Dhr. Van Baalen (LNV /DWK), Dhr. Maas (RIVM), Dhr. Stolwijk (CPB), Dhr. Wiersinga (IKC-Natuurbeheer)

\subsubsection{OPENING}

De voorzitter Bouma, opent de werkgroepbijeenkomst met een voorstelrondje en de aankondiging van de coreferenten. Daarna neemt Lammers, voorheen projectleider van de Natuurverkenningen ‘97, als eerste coreferent het woord.

\subsubsection{DE NATUURVERKENNING '97}

Lammers schetst de casus aan de hand van de ex-postanalyse en met een doorkijk naar de opzet van een nieuwe Natuurverkenning. De functies van de Natuurverkenning ' 97 , zoals die aan het managementteam zijn voorgelegd in 1995, waren:

1 meer op lange termijn denken;

2 het is een instrument om beleid te kunnen toetsen;

3 de aandacht voor het beleidsveld vergroten;

4 het speelveld van Natuur als sector verbreden met omgevingsfactoren: milieu, water en ruimte;

5 meer aandacht voor natuur en ecologie in een breder debat;

6 de onderzoekscapaciteit bij onderzoeksinstellingen bundelen tot producten die veel meer het beleidsproces dragen.

Er lagen een aantal percepties aan deze functies ten grondslag. Bijvoorbeeld, dat onderzoek ten dienste staat van strategische beleidskeuzen en de beleidscyclus. In de Natuurverkenning ' 97 is rekening gehouden met de cyclus waarin beleid gemaakt, uitgevoerd en geëvalueerd wordt.

Een tweede perceptie was de duidelijke rolverdeling tussen beleidsmakers en onderzoekers. De opdrachtnemer hanteerde geen netwerkbenadering. Er werd vanuit gegaan dat onderzoekers zorgen voor een wetenschappelijke onderbouwing en consensus in onderzoeksmethoden. De beleidsmakers zouden de strategische keuzen moeten maken. De beleidsmakers bepaalden in 1995 ook of het onderzoek in een netwerkverband, dat wil zeggen met maatschappelijke actoren, moest worden gedaan of niet. Hierop aansluitend was de derde perceptie waar vanuit 
werd gegaan bij het maken van de Natuurverkenning ' 97 dat het primaat van de besluitvorming bij de politiek ligt.

Een volgende perceptie bij de start van de Natuurverkenning ' 97 was, dat er geen nieuw beleid in zou komen zonder overleg met de opdrachtgevers. Gestart werd met een analyse van exogene ontwikkelingen om een beeld van problemen, uitgaande van bestaand beleid, te krijgen. Daarna zou pas gepraat kunnen worden over alternatieve beleidsdoelen. Dit had, volgens Lammers, een meer pragmaische dan principiële reden: de uitgangspunten voor de verkenningen moesten worden neergezet, en uitgaande van het huidige beleid waren er ook al veel nieuwe dingen gesignaleerd.

Voor de Natuurverkenning ' 97 is een aantal meer technische afspraken gemaakt. Onder andere dat de Natuurverkenning ' 97 moest aansluiten bij de CPB scenario's. Het vigerend beleid werd daardoor automatisch als uitgangspunt genomen want dat zit ook in de CPB scenario's. Bovendien moest er niet meteen iets nieuws geleverd worden. De verkenners maakten onderscheid tussen 'hard' beleid waarvan de verwachting was dat het uitgevoerd zou worden omdat het was vastgesteld, en beleid dat uit luchtkastelen bestond, waar nog geen afspraken over gemaakt waren. Bovendien was de effectiviteit van het huidig beleid nog niet onderzocht en dat kon in deze eerste verkenningen wel gebeuren.

In andere evaluaties van de Natuurverkenning ' 97 , bijvoorbeeld die van E. Dammers en $\mathrm{H}$. de Jong wordt geconstateerd dat de scheiding tussen beleid en onderzoek werd gemaakt omdat zowel de opdrachtgevers als de opdrachtnemers niet wilden 'lekken' van de een naar de ander. Het was een modelmatige invulling van de verkenningen doordat een voortraject ontbrak. Zij bevelen aan, om meer ontwerpend te werken. Bovendien werd de Natuurverkenning ' 97 een beetje in het luchtledige gemaakt omdat er geen aansluitend beleidsproces bij LNV was. Dat was verrassend voor de onderzoekers van het NPB. De Natuurverkenning '97 heeft in de kabinetsdiscussie over de ICES wel nadrukkelijk een rol gespeeld om te agenderen.

Lammers conclusie is dat hij zich kan vinden in de kenschets van de Natuurverkenning ' 97 in de 'Terugblik op toekomstverkenningen' als passend in een klassiek model. Daaraan verbindt hij uitdrukkelijk geen waardeoordeel. Hij is van mening dat er in de 'Terugblik op toekomstverkenningen' wel een premisse van de netwerkbenadering zit. Hij vindt in die benadering een interessante mix van willen, weten en kunnen zitten. Maar wat hem betreft, roept dit de volgende vraag op: waarom zouden politiek en beleid met het 'willen' van andere actoren rekening willen houden? De achterliggende discussie gaat over aannames over (aan)sturing. Bovendien staat daarbij ook ter discussie of onze huidige parlementaire democratie nog wel toegesneden is op de manier van besluiten nemen die je in de samenleving zou willen. 
Lammers stelt dat het 'willen' van de politiek uiteindelijk een ander 'willen' is dan dat van een verkenner of een maatschappelijke organisatie. De positie in een netwerk bepaalt wat het 'willen' van de actor is. De rolverdeling tijdens een proces is daarom essentieel. Zonder een goede procesorganisatie voor het vervlechten van 'willen', 'weten' en 'kunnen', ontstaan gaandeweg de grootste problemen. Lammers gaat er bovendien vanuit dat op het beleidsgebied 'Natuur' er weinig exogene ontwikkelingen zijn omdat er wordt afgesproken wat gewenst is en wat niet.

Lammers verwacht niet dat LNV voor een netwerkbenadering zal kiezen omdat zij heel duidelijk het onderscheid maakt tussen het 'willen' van de politiek en beleid en dat van andere factoren. Wel zal het Natuurplanbureau (NPB) als instituut zich er van bewust moeten zijn dat het verkenningenproces meer transparant en interactief moet verlopen. Ook kan de Natuurverkenning ' 97 meerdere beleidsdoelgroepen hebben, niet alleen de directie Natuurbeheer maar ook het parlement. De NPB-functie staat in dienst van beleid: het 'weten' en het 'kunnen' staan voorop. Er zou wel geëxperimenteerd kunnen worden met een mix van het modelleren en ontwerpen.

Van der Klundert is de tweede coreferent. Hij geeft als algemene kritiek op de 'Terugblik op toekomstverkenningen' dat de centrale vraag: 'hoe kan de effectiviteit van het gebruik van verkenningen in beleid vergroot worden', niet beantwoord is. Bij het beantwoorden van deze vraag moet het doel van de opdrachtgever het uitgangspunt zijn. En dat verschilt per verkenning. Van der Klundert mist in de 'Terugblik op toekomstverkenningen' ook de ambtelijke context van verkenningen.

Hij merkt op dat de opdrachtgevers van een verkenning en ook de verantwoordelijk bewindspersonen bij LNV nooit bestaand beleid ter discussies willen stellen, want daar zijn zij zelf verantwoordelijk voor. De variabelen die ter discussie mogen staan, zijn alleen externe variabelen.

Hij merkt ook op dat de verkenningencyclus parallel weliswaar aan de beleidscyclus van LNV was opgezet maar toch door politieke beslissingen overruled werd. In de 'Terugblik op toekomstverkenningen' krijgt de functie van (projectieve of prospectieve) scenario's te weinig aandacht. Van der Klundert vindt, evenals Lammers, dat in de volgende Natuurverkenning ' 97 de ontwerpende scenario's (binnen de huidige beleidskaders) meer ruimte zouden moeten krijgen.

Van der Klundert vindt voornamelijk de vergelijking tussen de verkenningen in de 'Terugblik op toekomstverkenningen' interessant en de epiloog die daarop gebaseerd is. Met name de opmerking dat de politiek de neiging heeft om zaken te zien als voorspellingen, terwijl een planbureau de scenario's blijft betitelen als geconstrueerde toekomsten. Ook wijst hij erop dat de samenhang in de regie en timing van verschillende verkenningen meer aandacht zou moeten krijgen. De laatste opmerking van Van der Klundert is dat in de nieuwe Natuurverkenning ook nieuwe 
doelgroepen aan bod moeten komen omdat er wel vanuit gegaan wordt dat de overheid samen met anderen verantwoordelijk is voor het natuurbeleid.

\subsubsection{DE STELUNGEN EN REACTIES}

Bouma introduceert de stellingen:

1 Ontvlechting van beleid en onderzoek is effectief geweest bij het produceren van beleidsondersteunende kennis.

2 De noodzaak (vraag) naar beleidsinnovatie is, gezien de cultuur, niet te verwachten

3 De overdraagbaarheid van kennis is wel effectief geweest (bijv. voor ICES).

4 Als je verkenningen wilt samen brengen, dan moet je er rekening mee houden dat het om verschillende verkenningen gaat.

5 Het discussiestuk gaat niet over de methode van het onderzoek zelf, maar toch rijst de vraag: zijn er nieuwe onderzoeksmethoden nodig?

\subsubsection{REACTIES OP STEWING 1}

Mevrouw Van Asselt (ICIS) vindt het interessant dat er aan de ene kant duidelijk sprake is van ontvlechting en dat aan de andere kant er een spanningsveld is tussen beleidsmakers en onderzoekers. Zij heeft dat in haar scriptie een 'naadloos web' genoemd waarin de actoren hun eigen grens definiëren. Ondanks de keurig geregisseerde ontvlechting, worden de grenzen door beide partijen anders gelegd. Naar haar idee ontstaat een spanning omdat mensen bij het RrvM het gevoel hebben dat beleidsambtenaren op hun terrein komen, en andersom. Hillebrand reageert hierop met de stelling dat 'willen' en 'weten' wel onderscheiden moeten worden maar niet gescheiden. Hij betrekt hierbij de tweede stelling: door te scheiden houdt je juist beleidsinnovatie tegen.

Van Baalen merkt op dat het uitmaakt in welke richting je 'willen' van 'weten' scheidt. Hij pleit voor een scheiding in de richting van het 'weten' naar het 'willen', en niet andersom. Een onderzoeker moet dus duidelijk aangeven wanneer die met het 'willen' bezig is.

Stolwijk ( $\mathrm{CPB}$ ) vindt dat ontvlechting van beleid en onderzoek geen 'brave' rapporten tot gevolg hoeft te hebben, want het 'willen' van de politiek is vaak heel abstract of algemeen gevormd. Onderzoekers hebben juist veel ruimte om te laten zien hoe de politieke doelstelling bereikt kan worden. Bovendien is hij van mening dat bij vervlechting een verantwoordelijk bewindspersoon niet aangesproken zal worden op de ontwikkelingen van 'interne' factoren op de lange termijn. Dammers wijst erop dat daarbij de relaties tussen de planbureaus en beleid een belangrijke rol spelen. Het CPB heeft een andere positie dan andere planbureaus. 
Maas ziet als grote voordeel van de ontvlechting in de Natuurverkenning ' 97 dat er tijd is geweest om na te denken en samenhangen aan te brengen in de verschillende onderdelen van natuurkennis en natuurbeleid en om de link te leggen met de CPB scenario's. Er is een raamwerk aan analysemethodes overgehouden dat ook bij andere dingen gebruikt kan worden, zoals bij ICES.

Hij ziet ook nadelen van de ontvlechting:

1 de link tussen het onderzoek en het beleidsproces is verloren gegaan want er werd vanuit gegaan dat de Natuurverkenning ' 97 in een Natuurbeleidsplan gebruikt zou worden, maar dat viel weg. Ontvlechting heeft een ontkoppeling van de beleidsdiscussie en het wetenschapsbeleid tot gevolg.

2 Het nadenken over de toekomst is door ontvlechting losgeknipt van het ministerie en wordt in handen gegeven van buitenstaanders, terwijl er toch een taak ligt voor strategische denkers.

3 Het communiceren over onzekerheden is bij ontvlechting ook weggehaald bij het ministerie. Dit zijn redenen om beleid en verkenning meer te vervlechten.

Dammers merkt op dat er verschillende opvattingen zijn over wat beleid is. LNV heeft in haar opdracht beleid in enge zin opgevat. LNV zal moeten inzien dat beleid niet te realiseren is zonder rekening te houden met de wensen van degenen die het beleid moeten ondersteunen en uitvoeren.

Van der Klundert denkt dat een open proces alleen mogelijk is als het ministerie van LNV de discussie entameert en zelf de regie in handen houdt. Bovendien zal er een bewindspersoon moeten zijn die dat aandurft en die boven de sectorbelangen (landbouw, natuurbeheer en visserij) staat.

Dammers vindt dit een erg defensief beleid van het ministerie. Kennis die het ministerie nodig heeft om scenario's te bouwen, ligt niet alleen bij de onderzoekers en beleidsmakers. De ervaringskennis van mensen is ook interessant. Van Asselt sluit hierbij aan en ziet in de verkenningen juist een mogelijkheid voor een open debat omdat er geen keuzen uit wensen of beleid gemaakt hoeven worden. Vos geeft aan dat scenario's voor beleidsmakers niet relevant zijn als zij niet eruit kunnen kiezen of beleidsopties voorgelegd krijgen. Dammers vindt dat er door beleidsmakers en politici gekozen moet worden voor robuust beleid. Van Asselt meent dat een politicus daarop ook afgerekend wordt. Zij geeft het voorbeeld van een scenariostudie naar mogelijke toekomsten in Kosovo. Het scenario dat uiteindelijk werkelijkheid is geworden, werd van tafel geveegd omdat men het niet waarschijnlijk achtte. Daardoor was men niet voorbereid en stonden de hulporganisaties niet meteen klaar.

\subsubsection{STELLING 3: DE OVERDRAMGBAARHEID VAN KENNIS UIT DE NATUURVERKENHING '97 WAS EFFECTIEF}

Vos laat zich kritisch uit over de, in zijn ogen, tegenstrijdig geformuleerde stellingen waarin enerzijds gesteld wordt dat de resultaten moeilijk overdraagbaar 
waren, en anderzijds dat zij grote impact hadden. Bovendien vindt hij het raar dat die effectiviteitvraag in het rapport niet aan de orde komt.

Metze merkt op dat het beantwoorden van deze effectiviteitvraag een ander soort onderzoek zou hebben vereist. Dan had gekeken moeten worden wat er van de verkenningen in het beleid terecht was gekomen. Daar is in de Terugblik op toekomstverkenningen' bewust niet voor gekozen.

Stolwijk geeft aan dat die vraag ook veel diffuser is omdat je niet precies je vinger erop kunt leggen wat het beleid met de verkenningen doet, die kennis sijpelt door. Van der Klundert vindt dat in de 'Terugblik op toekomstverkenningen' de effectiviteitsvraag goed ingekaderd zou moeten worden.

\subsubsection{TOT SLOT, DE LEERPUNTEN}

Van der Klundert vindt een grote verdienste van de Natuurverkenning ‘97, dat voor het eerst de nodige kennis op een rijtje stond. Maas vond het ook opvallend dat er een onvoorziene doelgroep was. Hij vermoedt dat het proces beter was verlopen als van het begin af aan de scenarioveronderstellingen ook met het ministerie waren gedeeld. Het geloof in de scenario's reikt over het algemeen niet verder dan de mensen die ze bedacht hebben.

Van der Klundert wijst erop dat een goede regie van de Natuurverkenning '97 nodig was omdat eenmalige verkenningen vaak de functie van een alarmerend scenario vervullen. Maas is van mening dat in de volgende verkenningen het beleidsproces wel op de agenda van de verkenners moet omdat er anders een herhaling komt van de Natuurverkenning '97. Van Asselt denkt dat wetenschappelijke kennis goed gebruikt kan worden om de ideeën en kennis die in interactierondes zijn verzameld op haalbaarheid te toetsen. Bouma zet vraagtekens bij een interactief proces dat gewoon 'blank' wordt neergezet en hij is van mening dat daar veel tijd in gaat zitten. Dammers geeft aan dat een goede organisatie inderdaad noodzakelijk is als je geen kakofonie wilt krijgen. De variëteit in kennis moet goed georganiseerd worden.

Lammers geeft ook een aantal leerpunten: een verdienste was dat door de bestaande kennis beter te benutten, hiaten aangegeven konden worden waarop onderzoeksprogramma's konden worden gestart. Een punt dat extra aandacht verdient, was dat in de Natuurverkenning ' 97 het moeilijk bleek om mensen bij elkaar te zetten die niet gewend zijn om met elkaar te werken. Lammers constateert dat zijn ambitie om met verkenningen te kunnen sturen en kennis te vergaren die in de toekomst nodig is een heel stuk lager is komen liggen. Van Asselt ziet in de verkenningen een hulpmiddel om interdisciplinair te werken, om integrale verkenningen te maken, en om op hoger niveau hiaten zichtbaar te maken.

De vraag blijft hoe samenhang gebracht kan worden in verschillende verkenningen. Stolwijk geeft als mogelijke oplossing dat al in een vroeg stadium met de 
wensen van de ministeries, bijvoorbeeld, rekening gehouden moet worden. Dammers wijst erop dat de WRR met dit doel is opgericht. Zij zou boven de sectorale verkenningen met integrale verkenningen moeten komen. Dat is niet goed gelukt.

Wiersinga merkt op dat de verkenningen een erg technische exercitie worden en dat het jammer is dat de normatieve verkenningen verdwijnen, want die zouden in de politiek goed gebruikt kunnen worden. De WRR verkenningen waren daar een voorbeeld van. Van Asselt is van mening dat een integrale aanpak ook beperkend kan zijn. De CPB verkenningen kunnen voor milieuverkenningen bijvoorbeeld heel beperkend zijn. Een scenario met als uitgangspunten een lage economische groei met een milieuvriendelijke samenleving zit er bijvoorbeeld niet bij want die wordt onwaarschijnlijk geacht (waarschijnlijk om legitieme redenen).

Lammers geeft aan dat het speelveld van de Natuurverkenning ' 97 het bestaande beleid was en de drie CPB scenario's. Hij is het er ook nog steeds mee eens dat op basis van die scenario's de toekomst voor natuur doorgedacht is. Over dat raamwerk was al consensus. Maar in de CPB scenario's zit weinig variatie. Er zou een slag verder gegaan kunnen worden buiten het huidige beleid en buiten de CPBscenario's. In de volgende verkenningen moet dat wel besproken worden. Daarbij speelt een rol of de verkenningen een instrument zijn om de discussie open te gooien, of niet.

Hillebrand vindt dat in de discussie het probleem is blijven liggen hoe je kunt bepalen wat interessante toekomsten zijn. Dat heeft niet met consensus over relevantie te maken maar met draagvlak.

\subsection{WERKGROEP NEDERLAND 2030}

Voorzitter: Dhr. Modder (stuurgroep T\&O, NIROv)

Coreferenten: Dhr. De Jong (VROM) en Dhr. Den Dunnen

Verslag: $\quad$ S. ter Woerds

Aanwezigen: Dhr. De Nooij (Provincie Zuid Holland), Dhr. Verbaan (RPD), Dhr. Tjallingii (Alterra), Dhr. De Haas (LNV, dienst landelijk gebied), Dhr. Van Ravesteyn (RPD), Dhr. Lever (RPD), Dhr. Roemer (Ministerie van oc\&w), Mw. Berkhout (NEI Rotterdam), Dhr. Straatsma (LTo Nederland), Mw. VersnelSchmitz (Vereniging Natuurmonumenten), Dhr. Frieling (TU Delft), Dhr. Dijkveld Stol (NRLO), Dhr. Morin (cos), Mw. Van der Werf (RPD), Mw. Nijhof (RPD), Dhr. Langeveld, Dhr. Scheltema (WRR). 


\subsubsection{OPENING EN STELIINGEN}

Modder opent de bijeenkomst. Het doel van vanmiddag is om lessen te leren. Het is niet de bedoeling nog een keer 'het varkentje 2030' te wassen. Hij introduceert de volgende stellingen:

1 Er is bij Nederland 2030 te weinig ontvlechting van beleid en toekomstverkenning geweest.

2 Politieke interventies zijn onvermijdelijk. Verkenningen dienen daartegen te worden gewapend.

3 Het ministerie van VROM is een vergetende organisatie. De geesten in de vakwereld zijn door Nederland 2030 wel rijp gemaakt voor beleidsverandering maar kennis wordt weer opnieuw geproduceerd. Er is te weinig continuïteit in leerervaringen.

De Jong reageert als eerste coreferent op de laatste stelling en vindt dat VROM juist een geheugen heeft als een olifant. Niet alle kennis is geïnternaliseerd omdat het ambtelijke apparaat niet voldoende overtuigd was.

In reactie op de eerste stelling vindt De Jong dat de verkenners het onderscheid tussen het sturingsperspectief en de beelden waarin de mogelijke ruimtelijke uitkomst in werd weergegeven hadden moeten verduidelijken. Met de tweede stelling is hij het eens: politieke interventies zijn er gewoon. Volgens hem heeft Minister De Boer dat bij Nederland 2030 uiterst correct gedaan.

De Jong reageert ook op het discussiestuk, de 'Terugblik op toekomstverkenningen' en is het met de vijf geconstateerde buigpunten eens. Maar volgens hem wilde niet de minister een vierde beeld maar waren er steeds al vier perspectieven. Verbaan bevestigt dit. De Jong vindt het een juiste constatering in de 'Terugblik' dat de verkenningen niet los hadden mogen komen te staan van het bestaande beleid. Binnen de organisatie was echter veel weerstand tegen vernieuwing van beleid van Vinex/ActVinex en daarom is bewust gekozen voor die ontvlechting. Dat heeft achteraf als een handicap gewerkt, want in de discussies werd het verband met het vigerende beleid toch gelegd. Ook was het inderdaad niet handig dat de overgang van verkenning naar beleid tegelijk plaatsvond met een ministerswissel.

De Jong is van mening dat er meer terecht is gekomen van de doelstellingen van Nederland 2030 dan uit de 'Terugblik op toekomstverkenningen' blijkt. Bijvoorbeeld, Nederland 2030 is gebruikt voor een aantal besluiten en bij het regeerakkoord, ten tweede heeft onder andere Nederland 2030 bijgedragen aan de hausse aan toekomststudies die inmiddels op gang is gebracht in het land. $\mathrm{Hij}$ vond het proces en de snelheid van Nederland 2030 goed.

Leerpunten zijn wat hem betreft dat er meer geïnvesteerd had moeten worden in de interdepartementale betrokkenheid. Ook had beter aan het begin van een kabinetsperiode begonnen kunnen worden. Bovendien had eerder geïnvesteerd 
moeten worden in de communicatie met de politieke bestuurders. Zo is De Boer pas laat echt betrokken geraakt bij het project. Volgens De Jong had een effectieve evaluatie van het bestaand beleid als startpunt genomen moeten worden. Daarnaast is hij van mening dat de doelstellingen van de perspectieven en het beeld, zoals geschetst op kaartjes, uit elkaar getrokken hadden moeten worden. Omdat dit laatste niet gedaan is, gingen de discussies vooral over de eindbeelden en niet over de doelstellingen. Een verkenning dient, wat De Jong betreft, niet direct gekoppeld te worden aan het beleid. Je kunt de verkenningen presenteren en los daarvan de beslissing nemen.

Den Dunnen is de tweede coreferent. In de 'Terugblik op toekomstverkenningen' vindt hij het analysekader met het onderscheid tussen 'willen', 'weten' en 'kunnen' erg vruchtbaar en hij stelt voor om dit op de agenda te zetten van komende verkenningentrajecten. Wat hem betreft gaat het in verkenningen om het onderscheiden van deze drie (willen, weten en kunnen) en de randvoorwaarden daarbij. Den Dunnen is van mening dat het buiten een ministerie plaatsen van verkenningen geen verschil zal opleveren voor de processen die rondom zo'n traject aan de gang zijn. Verder merkt hij op, dat op aanraden van Van der Werf, er een onderscheid tussen scenario's voor het bedrijfsleven en de overheid gemaakt zou moeten worden. De overheid is meer op normen gericht en zij zal in discussie moeten gaan en kan niet zomaar uitgaan van "dat weet ik dan”.

Over de laatste stelling, met betrekking tot het geheugenverlies van VROM, merkt Den Dunnen op dat het als organisatie vasthouden van kennis wél een probleem is, onder andere omdat mensen zich verplaatsen en doordat er vaak haast is in de beleidsvoorbereiding.

\subsubsection{STEUING 1: VERVLECHTEN EN ONTVLECHTEN}

Dijkveld-Stol denkt dat een strikte scheiding van 'willen' en 'kunnen' bij de overheid een probleem is. In het bedrijfsleven, bijvoorbeeld de scenario's van Shell, kan dat wel. Maar, de omgeving van de overheid is niet onbeinnloedbaar. De overheid bepaalt mede hoe Nederland er in de toekomst uitziet. De oplossing ligt wat hem betreft in het maken van procedureafspraken. Wat hem betreft is het 'weten' in Nederland 2030 te veel onder de tafel geschoven. "Je moet boven tafel tillen wat je zeker weet en wat je niet weet."

Frieling zou in de perspectieven van Nederland 2030 de meningen van de politieke partijen een meer prominente rol willen geven. Hij vindt het spreken in termen van een 'waarschijnlijke' toekomst en 'willen' verwarrend. De marges worden aangegeven door wetenschappelijke kennis. En de politiek positioneert zich volgens hem binnen die marges. Hij zou aan het 'willen', 'weten' en 'kunnen', 'het 'doen' willen toevoegen. Juist bij agendavormend werk, geeft het 'doen' een houvast voor de implicaties van de perspectieven. Zet de dingen die je moet 'doen' bij het open- 
baar bestuur, het 'willen' bij het parlement en het 'kunnen' bij het bestuur. Dat maakt het volgens Frieling voor de bevolking heel duidelijk.

Frieling vindt dat de verhouding tussen bestuur en parlement in de verkenningen aan de orde moet komen. Het 'oneens zijn' zou op tafel moeten liggen want dat zal er altijd zijn, maar er moet wél consensus zijn over wat we 'doen'. Het was bijvoorbeeld aardig geweest als de RPD haar eigen perspectieven had gelinkt aan die van de politieke partijen en dat daarover gediscussieerd werd.

Den Dunnen is van mening dat een kennisverkenning met 'doen' overbelast zou worden. De politieke agenda is er wel. Als het 'doen' eerder in het traject geïntroduceerd wordt, dan zouden bijvoorbeeld alle grote steden gaan opspelen. Het 'doen' gebeurt in een andere fase. Lever vindt het terecht als er over het 'doen' gedacht wordt. Maar het verdelen van de rollen betreffende 'willen', 'weten', 'kunnen' en 'doen' is kunstmatig. Het is niet zo te verdelen, noch uit elkaar te trekken.

Versnel-Schmitz is van mening dat de vermenging van twee functies, de planbureaufunctie en de beleidsfunctie, onvergeeflijk was. Door die menging in de presentatie werd het keuzeperspectief geinntroduceerd. Het 'kunnen' is wat haar betreft beleidsmatig. Als het beleid vanaf het beginpunt van het verkenningentraject meespeelt, dan krijg je op een verkeerd moment de mix van 'willen', 'weten' en 'kunnen'.

De Haas vindt de spanning tussen de planbureaufunctie en de beleidsfunctie een schaalkwestie. Het RIVM werkt bijvoorbeeld met duidelijke wetenschappelijke kennis. Een milieuverkenning geeft een ander signaal en werkt met harder materiaal.

Modder vraagt of voorkomen had kunnen worden dat er gekozen werd tussen de scenario's. Lever constateert dat ook De VROM -raad niet boven het keuze-denken stond. Nijhof vult aan dat er sprake was van misinterpretaties van de scenario's. Van der Werf denkt dat, om te voorkomen dat uit de scenario's gekozen zou worden, een fase ingelast had kunnen worden waarin bekeken werd wat de beleidsuitgangspunten waren in de scenario's. Maar zij vindt het belangrijker om na te gaan hoe met de conclusies uit de discussies over de streefbeelden is omgegaan.

\subsubsection{STEWING 3: HET VERGETENDE MINISTERIE}

Naar aanleiding van de stelling over het ministerie als vergetende organisatie, merkt De Nooij op dat er veel fantastische studies worden gedaan, bijvoorbeeld naar Schiphol. Maar dat altijd gekozen wordt voor het plan dat de minste verandering met zich meebrengt. Een echt grensverleggend debat kan bijna niet. 
Verbaan noemt een aantal pluspunten aan Nederland 2030:

1 Er is bijvoorbeeld niet over het verleden gesproken en er zijn dus nieuwe probleemstellingen geformuleerd.

2 De VROM-raad werkt nog steeds met onderdelen van de scenario's.

3 De huidige minister neemt tijd voor de vijfde nota, dat is goed.

4 En elementen uit de scenario's komen weer terug in de discussies.

Van Ravesteyn is verbaasd dat het niet gelukt is om zich aan de afspraak te houden van het planbureau om de Woonverkenningen en Nederland 2030 op hetzelfde moment uit te brengen. Ook is hij verbaasd dat de politiek Nederland $2030 \mathrm{zag}$ als een speeltje van ambtenaren en een afwachtende houding aannamen.

Tjallingii vond met name de relatie tussen ICES en Nederland 2030 interessant. Bij ICES is wel gekeken naar "welke brug investeerders nodig hebben naar de toekomst”. Daar is te weinig aandacht aan besteed bij Nederland 2030.

Scheltema vraagt in hoeverre het is gelukt om de verkenningen van VROM buiten de organisatie kenbaar te maken. Wellicht is men buiten het ministerie van VROM deze studies niet vergeten.

Morin is van mening dat in een policentrische besluitvorming je niet alles meteen hoeft te weten. Besluitvormers moeten gebruik maken van wat er al is en de indruk wegnemen van 'de ivoren toren'.

Nijhof is van mening dat algemeen overdraagbare kennis niet bestaat. Het gaat om kennis in netwerken. Maar het is zinnig de mensen te betrekken die reeds in het verkenningen- of besluitvormingsproces aan tafel zitten.

Frieling stelt voor om de ambtenaren te verplichten alle rapporten en onderzoeken nog een keer te lezen. Bijvoorbeeld, in Amsterdam is er veel aandacht, via cursussen, voor het Amsterdams beleid en de Amsterdamse beleidsgeschiedenis.

Modder vat de gedachten rond de drie stellingen in de groep samen:

Ad 1: Het is geen realistisch oplossing om organisatorisch te ontvlechten, wel is het verkenningenproces transparanter te maken.

Ad 2: Er dient meer ontspannen omgegaan te worden met interventies.

Ad 3: VROM is een olifant. De kennis blijft wel binnen de organisatie. Maar een vraag is hoe te voorkomen is dat VROM vergeet? 


\subsection{WERKGROEP WOONVERKENNINGEN}

$\begin{array}{ll}\text { Voorzitter: } & \text { Dhr. Van der Zande (stuurgroep T\&O, Alterra) } \\ \text { Coreferenten: } & \text { Dhr. Tommel (Nationale Woningraad) en Dhr. Kokhuis (Min. } \\ & \text { VROM), Dhr. Rutjens (NMB-Amstelland) } \\ \text { Verslag: } & \text { Dhr. den Hertog } \\ \text { Aanwezigen: } & \text { Mw. Booi (Laagland advies), Dhr. Schuyt (Woningcorporatie } \\ & \text { SCw), Dhr. Hordijk (Provincie Zuid Holland), Mw. Alberda } \\ & \text { (Instituut voor Maatschappelijke Innovatie), Dhr. Stoffers (CPB), } \\ & \text { Dhr. Brouwer (ABF Onderzoek), Dhr. Koffijberg (VROM / DGVH), } \\ & \text { Dhr. Haarmann (Telos), Mw. Vlug (IPP), Dhr. Strik, } \\ & \text { Dhr. Tiemersma }\end{array}$

\subsubsection{OPENING EN STELINGEN}

Van der Zande opent de bijeenkomst en geeft het woord aan Tommel. Deze benadrukt dat niet hij maar dhr. Kokhuis de opdrachtgever voor deze verkenningen was. Tommel schetst de context van de Woonverkenningen: In de eerste plaats waren er op het gebied van de volkshuisvesting grote veranderingen. Er was een soort tussenfase in het beleid waarin al besluiten waren genomen die nog moesten worden geïmplementeerd, maar die niet zouden leiden tot een stationaire eindfase. Tommel vond het belangrijk om in deze fase na te denken over de toekomst die iets verder strekte dan de eerste paar jaar. Het tweede punt dat een rol speelde was de vraag of er ook een nieuwe nota moest Volkshuisvesting komen. Tommel was er van overtuigd dat er grote druk zou zijn om een nieuwe nota te maken. Het was verstandig om daarvoor wat voorwerk te verrichten. Bovendien wilde het directoraat-generaal voor de Volkshuisvesting ook zijn eigen rol en positie bekijken. Tommel heeft ten behoeve van de discussie de volgende stellingen opgesteld:

1 Bewindslieden dienen de ruimte van de toekomstverkenning zo min mogelijk in te perken. Politiek gestuurde toekomstverkenningen hebben weinig waarde. Hij beargumenteert deze stelling met een verwijzing naar de driehoek van 'weten', 'kunnen' en 'willen'. Hij is van mening dat wat de bewindsman nu 'wil' over dertig jaar volstrekt oninteressant is.

2 Het proces waarmee toekomstverkenningen tot stand komen, moet aan hoge eisen voldoen: alle betrokkenen (in de meest brede zin) bij het betreffende beleidsterrein moeten hun inbreng kunnen leveren, en er moet een open gedachtewisseling met en tussen participanten worden georganiseerd. Mogelijk vooropgezette meningen bij de opstellers van de toekomstverkenningen dienen krachtig de kop in te worden gedrukt.

3 Bij de Woonverkenningen is er terecht uitgegaan van hetgeen redelijk haalbaar leek te zijn. Deze benadering heeft sterk bijgedragen tot de waardering in 'het veld' voor de Woonverkenningen. Een document dat louter een abstracte betekenis heeft kan in de kast gelegd worden. Mensen in het veld moeten zich 
juist druk maken over dat document en het gevoel hebben dat het de moeite waard is om het te toetsen.

De tweede coreferent, Kokhuis (directeur-generaal van DGVH) was de opdrachtgever van de Woonverkenningen. De stellingen roepen bij hem weinig tegenspraak op. Hij is het ermee eens dat er ruimte moet zijn voor onderzoek, maar de verkenners moeten ook geremd worden als zij hun terrein gaan verlaten en overgaan in de sfeer van de politieke statements. Er mogen geen politieke statements uitgesproken worden die een bewindspersoon last kunnen bezorgen. De ambtelijke opdrachtgever moet exact weten tot hoever hij kan gaan.

Bij de tweede stelling geeft Kokhuis aan dat de Woonverkenningen een inhoudelijk middel zijn geweest om een deel van de organisatievernieuwing door te zetten. Die ambtelijke reorganisatie in 1993 en 1994 kwam voort uit de Nota Heerma uit 1989 die als submotto had: 'van bouwen naar wonen'. In de reorganisatie werd een overgang gemaakt van een subsidiefabriek ("een beetje dat stalinistische volkshuisvestingsmodel uit de 70'er 80'er jaren") naar een beleidsontwikkelend directoraat. In 1994 werd voor de eerste keer binnen het DGVH een directiestrategie ontwikkeld. Voorheen was die niet nodig want er werd alleen geld uitgegeven en subsidieregelingen bedacht.

Het was voor het directoraat dus de eerste keer dat er veel ruimte was voor stevige discussies met verschillende mensen. $\mathrm{Er}$ is meteen voor een uitermate interactieve aanpak gekozen die doorwerkte in de sturingsopvatting over hoe het ministerie (het directoraat) met andere overheden en bestuurslagen om zou gaan. Deze meer interactieve werkwijze, die geoefend is in de Woonverkenningen, ligt nu eigenlijk in een wetsontwerp vast.

Het 'haalbare' van de derde stelling is, wat betreft Kokhuis, in de Woonverkenningen ruim genomen. Meer visionaire en creatieve dingen mochten ook best wel.

\subsubsection{STELING 1: VERVLECHTING EN ONTVLECHTING}

Booi vindt dat de politiek een belangrijke rol speelt en dat zij in het verkenningentraject ook een rol moet krijgen die past bij de politieke identiteit. Aan het begin van het proces moet de politiek zoveel mogelijk afstand nemen (ontvlechten). Maar haar taak moet niet ontkend worden en interventie moeten ingecalculeerd worden.

Rutjens was projectleider van de Woonverkenningen. Hij merkt op dat hij de interventies en de rol van de staatssecretaris daarin als bijzonder prettig heeft ervaren. Met name aan het begin, toen de opdracht samen met de opdrachtgever Kokhuis besproken is, en aan het einde bij het opstellen van het rapport. Dit waren geplande interventiemomenten. Hij is van mening dat verkennen "de kunst is van het nog geen keuze maken.” In de Woonverkenningen zijn de keuzen en gewenste 
keuzen van anderen geïnventariseerd. Wat hem betreft hoort het bij de integriteit van de opdrachtnemer om zo veel mogelijk meningen en keuzen van anderen in het document op te nemen.

Booi ziet als doel van de verkenningen om zo veel mogelijk te ontdekken. Daarbij is er verschil tussen een conceptuele fase en de fase van politieke besluitvorming, met daartussen in de politieke visievorming.

Schuyt vindt dat de kneep zit in het woord 'sturen'. Politieke interventies zijn onontkoombaar en moeten daarom georganiseerd worden. In de Woonverkenningen is dat heel behoorlijke geslaagd. Hij vraagt zich af of een departement, of een bewindspersoon, wel het risico moet lopen dat de sturingselementen van de politiek in interactie worden geconstrueerd. Misschien is het beter om het meer in de luwte te organiseren. Met name als het interne organisatorische consequenties heeft, zal het aantrekkelijker zijn om dit proces in eigen huis te houden. Tegelijkertijd is het departement de hele dag bezig met politiek en de effecten van hun handelen op de politiek. Daarmee is het misschien de goden verzoeken om de verkenningen buiten de politiek te houden.

Kokhuis is van mening dat er nagedacht moet worden over hoe de politiek en het politiek primaat nu en in de toekomst moeten sturen. Er is niet meer van bovenaf te sturen, dus moet de politiek zichzelf wat op de achtergrond schuiven en moet zij via het ambtelijk apparaat en op interactieve wijze de bouwstenen op tafel moet krijgen, om daar vervolgens politiek uit te kiezen. Booi merkt op dat dit proces per departement verschilt, en ook per gemeente. Ambtenaren leggen zich soms wel beperkingen op en soms niet.

Hordijk heeft het idee dat de organisatie DGVH vanuit een breder kader naar de buitenwereld wilde kijken. Doordat buiten kijf stond dat er over dertig jaar andere meningen zouden bestaan in de buitenwereld over het wonen, is het verschil tussen 'willen' en 'weten' in het traject van Woonverkenningen wat natuurlijker afgewikkeld dan in het traject Nederland 2030. In de Woonverkenningen wilde de organisatie zo veel mogelijk geluiden waar nemen. Daardoor stelde de organisatie zich veel minder kwetsbaar op en is de spanning tussen de verkenning en de gejuridiseerde beleidsvorming niet zo groot geworden.

Alberda merkt op dat in één persoon het 'willen', 'kunnen' en 'weten' vaak heel goed geīntegreerd is. "Iemand gaat goed luisteren en zijn oren open zetten als hij het niet goed weet." Hij is van mening dat in Nederland 2030 mevrouw de Boer het nog niet had moeten 'weten', om die verkenningen een kans te geven.

Rutjens noemt nog een groot verschil tussen Nederland 2030 en de Woonverkenningen. In de Woonverkenningen is wel een agenda geformuleerd voor de voorliggende keuzen. Bij Nederland 2030 lag de scheiding tussen 'kennen' en 'willen' vanuit het politiek perspectief van de opdrachtgever totaal anders. Tommel geeft aan dat er hierbij voortdurend een risico is dat zo'n agenda verwatert en verglijdt. 
Er wordt gesproken over 2030 maar tegelijkertijd moet "in de documenten gekeken worden" naar de uitvoering. In de verkenningen wordt geestelijk een beetje afstand genomen van de dingen die vandaag gebeuren, zodat niet weer vanuit de belemmeringen van vandaag geschreven wordt. Daarom is het ook goed dat er een interactie bestaat tussen mensen van binnen en mensen van buiten, want die hebben allemaal hun eigen vrijheid.

Schuyt vindt dat binnen een verkenning uitdrukkelijk een extern bureau de opdracht moet krijgen om te onderzoeken hoe Nederland in 2030 eruit ziet met bijvoorbeeld een afgeschafte hypotheekrente. Juist door een erg politieke verkenning te maken, wordt de angel eruit gehaald.

Op dit punt komt de vraag naar boven of het al dan niet extern plaatsen van verkenningen een bijdrage aan vervlechting of ontvlechting kan leveren. Van der Zande constateert dat het model waarin de verkenningen bij een planbureau neergelegd worden, voor de ambtenaren met 'strategie' op hun naambordjes het nadeel heeft dat zij droog komen te staan. Aan de andere kant kan het binnen een ministerie plaatsen van de verkenningen tot zelfcensuur leiden, omdat er tegelijkertijd nieuw beleid gemaakt en vigerend beleid uitgevoerd wordt. Hij ziet bij (onafhankelijke) planbureaus ook wel discussies over het inkapselen en innemen van uitspraken en kennis. Bovendien, is hij van mening, definieert een technocratie zoals het CPB al het politieke weg met een gigantisch economisch model. Dit maakt de politiek ook minder wervend.

Rutjens is van mening dat, om politiek meer wervend te krijgen, zij in de kennisverwerving van de planbureaus betrokken moet worden. Een andere manier kan zijn door de kennisverwerving heel dicht bij de praktijk van alle participanten te leggen.

Strik wijst ook op de problematische gelijktijdigheid voor een ministerie met een beleidsfunctie en een planbureaufunctie. Er wordt tegelijkertijd gesproken over de toekomstvisies en de rol van actoren in dat veld, en het beleid moet in de praktijk uitgevoerd worden. In de verkenningen werd bijvoorbeeld gesproken over de mogelijkheid om de relatie tussen de woningcorporatie en de zorginstelling in de verre toekomst verder dan een huurrelatie te laten gaan maar in de praktijk werd een corporatie die dit inderdaad aan het onderzoeken was, teruggefloten door een inspecteur uit Haarlem. Dit is verwarrend voor partijen in het veld. Op het moment dat de discussie over de toekomst begint zou er bijvoorbeeld in het huidig beleid een soort pas op de plaats gemaakt moeten worden, een soort interim beleid gaan gelden.

Tommel vindt ook dat, als beleid uitgevoerd moet worden, er altijd een spanning is om tegelijkertijd over de toekomst na te denken en die ideeën nu nog niet uit te voeren. Daarom moet er in de woonverkenningen constant rekening mee gehouden worden dat het over een termijn van dertig jaar gaat. Hij wil in de verkenning géén fase waarin geleidelijk overgegaan wordt van het inventariseren naar een politieke besluitvorming. Dat kan alleen als de politieke opdrachtgever abso- 
luut vertrouwen heeft in degene die het verkenningstraject uitvoeren. Dit vraagt ook vertrouwen en integriteit van degenen die het traject uitvoeren. Daarbij is het inderdaad de vraag of de verkenningen uitbesteed, of intern, gedaan moeten worden. Bij de Woonverkenningen is voor een intern proces gekozen omdat de organisatie zich aan het opbouwen was en dit ook een methode was om het DGVH zelf weer eens wat te laten doen. Hij vindt het ook in hoge mate interessant om te zien dat binnen één departement vanuit twee volstrekt verschillende instellingen verkenningen gemaakt zijn. In Nederland 2030 is gewerkt vanuit de vraag hoe zou ik het willen hebben?'. In de Woonverkenningen was het uitgangspunt de vraag 'Welke ideeën heeft iedereen die in Nederland iets met dat terrein te maken heeft over hoe het zou moeten?'

Brouwer is van mening dat de Woonverkenningen sterk afwijkend waren van al die andere verkenningen. In de Woonverkenningen was de start: wat wil de bewoner? Rutjens is van mening dat de vraag naar wat iedere betrokkene wil niet te vermijden is op het moment dat gekozen wordt om een verkenning uit te voeren waarbij uitgegaan wordt van een netwerksamenleving. Dat betekent dat op een andere manier de politieke besluitvorming wordt voorbereid.

Stoffers merkt op dat het CPB het wel heel belangrijk vindt om onafhankelijk te zijn, omdat het de ruimte geeft om eigen ideeën naar voren te brengen. Aan de andere kant zit het CPB ook in een departementale organisatie waardoor met die organisatie goed en indringend gecommuniceerd kan worden zodat ook beleidsopvattingen -wensen en -vragen in de CPB -producten verdisconteerd kunnen worden. Rutjens stipt naar aanleiding van deze opmerking een ander probleem aan op basis van zijn ervaringen met de strategieontwikkeling voor milieubeheer en het NMP2: "hoe kan, op basis van de wetenschappelijk onderzoeksresultaten aangegeven worden wat de waarschijnlijke toekomst is van het milieuvraagstuk en hoe kunnen we de juiste en tevens beste beleidsmaatregelen treffen om dat probleem in te perken". Hij merkt op dat dit vanuit een wetenschappelijke discipline een benadering is waarmee beleid wordt gelegitimeerd. Een beleidslegitimering die vanuit een planbureau (op onafhankelijke en wetenschappelijke wijze) tot stand komt, is een wezenlijk andere dan die van de beleidslegitimering zoals die in het kader van de Woonverkenningen tot stand is gekomen. Kennis heeft in de Woonverkenningen een hele andere taak gekregen. Wetenschappelijke kennis is wel gebruikt in het proces maar was geen primaire legitimering van de keuzen die zijn gemaakt.

Booi vindt dat naast de legitimering van beleid er ook een aantal andere redenen kunnen zijn om een verkenningenproces intern te doen, en niet extern, bijvoorbeeld het gevoel creëren bij maatschappelijk actoren dat het ministerie dichterbij komt. Men kan zijn verhaal dan direct kwijt bij degenen die daarvoor meteen verantwoordelijk zijn. Van der Zande vindt dat nevenproducten van een verkenningenproces. Kokhuis vindt dit geen nevenproduct maar een van de doelen. 
Booi is van mening dat bij de Woonverkenningen aan de 'voorkant' van het proces goed is nagedacht over de rol die de politiek in zou moeten nemen. En dat is bij de ruimtelijke verkenningen niet gebeurd. $\mathrm{Zij}$ is van mening dat op het moment dat besloten is om Woonverkenningen te maken, dat niet ins Blauen hinein gebeurt. "Bij elk proces moet van tevoren het politiek commitment verkregen worden voor hetgeen je wilt gaan doen en de doelstellingen." Ten tweede moet met de politiek worden afgesproken op welke wijze en op welk moment zij hun rol kunnen spelen en welke rol dat is. Soms is dat een plaats binnen de verkenningen of in de conceptuele fase. De politiek kan dan terugkoppelen naar de eigen politieke achterban, en daarna weer naar het proces. Soms speelt de politiek een rol aan het einde van de conceptuele fase waarbij zij na moet gaan denken over besluiten.

Vug is het hiermee eens en denkt dat de politieke agendapunten zeker ook tijdens het verkenningenproces een rol spelen. “Als daar geen rekening mee gehouden wordt, dan loop je het risico dat de politiek juist weer teruggefloten wordt.” Politieke betrokkenheid moet georganiseerd worden.

Van der Zande merkt op dat nu de tweede stelling interessant wordt, omdat de ervaringen onder andere ook in de stuurgroep zijn dat de bereidheid van participanten om erbij te blijven, afhangt van het zicht dat men heeft op de doorwerking van verkenningen. Als de agendering te vrijblijvend is dan haken mensen af. Booi vindt dat van tevoren goed over de verwachtingen van het proces moet worden gesproken en over de politieke rol. Kokhuis is het daar mee eens. Volgens hem hangt het in essentie samen met de vraag welke mensen expliciet en goed met elkaar communiceren. Dat is eigenlijk heel basaal, maar dat bepaalt in belangrijke mate het proces. Manieren van communiceren kunnen - binnen hetzelfde departement fundamenteel verschillend zijn en dat ligt aan alle mensen, niet alleen aan de ambtenaren of aan de politici. Rutjens is het daar roerend mee eens. Hij is van mening dat het heel belangrijk is hoe de arena georganiseerd wordt en hoe daarbinnen gecommuniceerd wordt. In de Woonverkenningen is daar heel veel aandacht aan besteed. Daarbij is een heel open scan gemaakt van wie in die arena uitgenodigd zouden moeten worden.

De toon en de manier waarop de thema's aan de orde gesteld worden zijn volgens Rutjens ook belangrijk. Op het moment dat een politieke stellingname geïntroduceerd wordt, dan wordt er gepolitiseerd. In de Woonverkenningen is geprobeerd iedereen een plek te geven. Daardoor is iedereen ook betrokken gebleven.

Van der Zande ziet drie opvattingen over de rol van de politiek in de discussies:

1 De politiek als inhoudelijk stuurder;

2 De politiek als relevante actor;

3 De politiek als facilitator van het proces.

Daarnaast hoort hij in de discussie terugkomen dat er een dringende wens is om de rol van de politiek zo expliciet mogelijk te maken, en ruimte te creëren om daar 
heel bewust over na te denken. Ook moet goed gerealiseerd worden dat de politiek-maatschappelijke uitgangssituaties van de verkenningen erg verschillend zijn.

Van der Zande sluit de bijeenkomst af aan de hand van de stellingen van Tommel en de drie punten van Teisman. Hij heeft zelf de indruk dat er veel gesproken is over de rol van politieke sturing en eigenlijk voortdurend in samenhang met de organisatie van het verkenningenproces. Vrijheden, geduld, actorgeoriënteerd. De derde stelling is wat minder aan de orde gekomen. Daarin zat de spanning van realiteit versus vernieuwend.

Brouwer vindt dat er veel nadruk ligt op het in kaart brengen van het probleem bij alle verkenningen, en dat het 'kunnen' heel slecht uit de verf komt. “Er wordt een heleboel mankracht, kennis en kunde of 'willen' en 'weten' in kaart gebracht. Maar de toekomst maak je ook door hem te ontwerpen. Er zijn een heleboel mensen die oordelen dat iets niet kan of dat het moeilijk is of dat het een bepaalde kant opgaat, maar heel weinig aandacht is er voor het zoeken naar, en openen van mogelijkheden."

Stoffers is van mening dat er meer samengewerkt zou kunnen worden. Als mensen met kennis bij elkaar gebracht worden, dan kan efficiënter gebruik gemaakt worden van bestaande informatie.

Koffijberg mist in de 'Terugblik op toekomstverkenningen' dat, nadat de Woonverkenningen gepubliceerd zijn in een ambtelijk rapport, de politiek het stuk heeft overgenomen en er daarna nog een heel maatschappelijk debat is georganiseerd. Dat toen de agenda opnieuw breed is bediscussieerd. Daarvan was het perspectief ook dat de uitkomsten zouden worden meegenomen in de kabinetsformatie. Daaruit is de nota Wonen ontstaan.

Alberda denkt dat het goed zou zijn als de verkenningen breder bekeken zouden worden, omdat er pas daadwerkelijk geleerd kan worden als de conflicten ook goed ter discussie gesteld worden.

Vlug werkt bij het Instituut voor Publiek en Politiek en is van mening dat meer gebruik van omgevingsscenario's gemaakt zou moeten worden om het ondenkbare denkbaar te maken.

Van der Zande sluit af met de woorden dat, onder andere, de sectorraden en de stuurgroep T\&O in de discussies, zoals die van vanmiddag, ontdekken dat er weinig gemeenschappelijke, vergelijkende kennis is over de verkenningenprocessen en dat een stukje professionalisering van beleidsmakers om meer kennis te nemen van die processen er misschien een extra duw aan zou kunnen geven. 


\subsection{WERKGROEP QUESTA}

\begin{tabular}{|c|c|}
\hline Voorzitter: & Dhr. Van Latesteijn (stuurgroep T\&O, WRR) \\
\hline Coreferenten: & $\begin{array}{l}\text { Dhr. Keijts (plaatsvervangend DG v\&w) en Dhr. Schuring } \\
\text { (voorheen projectleider Questa, nu werkzaam bij de RLD) }\end{array}$ \\
\hline Verslag: & Mw. Ermers \\
\hline Aanwezigen: & $\begin{array}{l}\text { Mw. Van Donselaar (NEI, transport), Dhr. Verroen (TNO-INRO), } \\
\text { Dhr. Van Alphen (RMNO), Dhr. Meester (LNV), Dhr. Sakkers } \\
\text { (afd. Strategisch beleid gemeente Utrecht), Dhr. Dikmans (v\&w, } \\
\text { afd. S en C), Dhr. Schartman (v\&w, afd. s en c), Dhr. Saris } \\
\text { (De Stad B.v., projectsecretaris T\&O) }\end{array}$ \\
\hline
\end{tabular}

\subsubsection{OPENING EN STELIMGEN}

Van Latesteijn heet iedereen van harte welkom. Het doel van deze bijeenkomst is het verzamelen van leerpunten voor de stuurgroep T\&o en het delen van inzichten en ideeën. De stellingen zijn:

1 Bij Questa waren zowel ontvlechting als vervlechting van beleid en onderzoek uitdrukkelijk de bedoeling. Dit moest bereikt worden door zich te richten op mogelijke toekomsten, ten einde randvoorwaarden op het spoor te komen voor wenselijke toekomsten.

2 Doordat er geen duidelijke methode was ontwikkeld om de mogelijke toekomstbeelden over te dragen aan andere beleidsonderdelen van het ministerie, is het project slechts half geslaagd.

3 Net als bij andere toekomststudies gericht op beleid dient ook bij Questa de ambitie tot vervlechting deel uit te maken van het proces. In de praktijk blijkt dit onderdeel maar moeilijk tot ontwikkeling te brengen omdat het zich bevindt in een niemandsland tussen het aandachtsgebied van de onderzoekers en het verantwoordelijkheidsgebied van de beleidsmakers.

\subsubsection{STEUING 1: VERVLECHTEN EN ONTVLECHTEN}

Keijts reageert als eerste coreferent op de stellingen. De bedoeling bij Questa was om hulpmiddelen te ontwikkelen voor de beleidsmakers waarmee zij hun huidige strategie konden toetsen op robuustheid. Er werd onderzocht wat het betekent als de huidige beleidsinstrumenten in een heel nieuwe wereld worden gezet. Voor ontvlechting zijn scenario's nodig waarin de beleving van beleidsmakers niet zit.

Vervolgens moeten de beleidsmakers er wel mee gaan werken, om te kijken of ze het huidige beleid bij moeten stellen. Dus eerst moet ontvlochten worden met als uiteindelijke doel om weer te vervlechten. Het 'willen' was bij Questa het formele uitgangspunt. In het verkenningentraject moest dat 'willen' worden losgelaten en op robuustheid getoetst worden. Keijts geeft aan dat voor het maken van complex beleid een hele machine in gang wordt gezet. Uitgetest zou moeten worden of de 
uitgezette koers voor over tien jaar nog steeds valide is. Met scenario's kan getoetst worden of beleid en beleidsinstrumenten robuust zijn. In het achterhoofd was ook het doel om de proceseisen te achterhalen en om meer opties te genereren en flexibel te zijn in de toekomst.

Schuring was destijds de Projectleider van Questa. Hij merkt op dat in 'Terugblik op toekomstverkenningen' wordt gesproken over het ontvlechten van het 'willen', 'weten' en 'kunnen'. Binnen Questa waren dit de 'wenselijke' en 'mogelijke' toekomsten. De scenario's zouden werelden moeten zijn, die je zouden kunnen overkomen. Verroen vond het thema van vervlechten en ontvlechten bij Questa spannend. Enerzijds was het doel om het leerproces op gang te brengen en mensen te laten participeren. Anderzijds had Questa een eigen traject en moest zij een beleidsdiscussie losmaken. Juist op het laatste punt heeft Verroen het gevoel dat de follow-up van zo'n proces lastig te organiseren is. Schuring merkt op dat, onder andere, daarom in de beginfase er gesprekrondes zijn gehouden met het management waarin het probleem voor de verkenningen werd afgebakend.

Keijts is van mening dat dit soort activiteiten niet begonnen moeten worden als er bij het management, of de opdrachtgever, geen belangstelling is een bepaalde aanpak te gebruiken. Bij Questa was die er in de beginfase wel. Volgens hem zijn verkenningen niet meer dan een hulpmiddel. Op het moment dat in de voorfase dingen niet goed geregeld zijn, dan ontstaat het risico dat niks gedaan wordt met de verkenningen, of op een andere manier dan de bedoeling was.

Sakkers geeft aan dat in de grote steden discussies over verkenningen enorm zijn opgelaaid. Voor een deel is het kader waarin gesproken wordt hetzelfde. Maar, het verschil tussen onderzoek en beleid wordt door de steden niet geproblematiseerd. In plaats van over 'wenselijk' wordt vaak over 'maatschappelijke acceptatie' gesproken. Daarbij wordt vaak de volgende formule gehanteerd: $\mathrm{E}=\mathrm{K} \times \mathrm{A}$. E is daarbij het maatschappelijk effect, de $\mathrm{K}$ voor de kwaliteit van het beleid, zowel wetenschappelijk als deskundig, en de A staat voor Maatschappelijke Acceptatie. Als een van de waarden nul bedraagt zal het maatschappelijk effect ook nul zijn. In deze formulering worden beleid en onderzoek dicht tegen elkaar aan geformuleerd.

Saris ziet dit als twee verschillende invullingen van scenario onderzoek. Questa was het bouwen van omgevingsscenario's, die gebruikt konden worden om te toetsen of beleidsvoornemens enige robuustheid bezaten. De scenario's in de steden zijn terug te voeren tot de verschillen in normatieve referenties die in de samenleving herkend worden. Aansluitend vraagt Saris vraagt of de scenario's die voor Questa gemaakt zijn, omgevingsscenario's waren. Schuring is van mening dat, in tegenstelling tot wat in de 'Terugblik op toekomstverkenningen' staat, er geen wenselijkheden ingeslopen waren. $\mathrm{Hij}$ is van mening dat het projectteam erin geslaagd is om voorstelbare toekomsten te schetsen. Met een doorkijkje naar de 
mobiliteitsbeelden in die mogelijke toekomstige werelden die niet ontstaan zijn ten gevolge van beleid.

Dikmans is van mening dat er wel beleid ingeslopen is door bijvoorbeeld vast te houden aan de economische randvoorwaarden van het CPB. Het projectteam was bang dat er moeilijk gecommuniceerd zou kunnen worden met de buitenwereld als er verschillen zouden komen tussen de Haagse werkelijkheid en die van het team. Saris ziet twee risico's van het toevoegen van beleid in de mogelijke (voorstelbare) scenario's: beleidsmatige wensen in de scenario's maken ze als toetsingsinstrument onbruikbaar. Ten tweede wordt een onzekerheidsreductie ingevoerd via $\mathrm{CPB}-$ scenario's. De vraag is of die scenario's over de wereldeconomie wel gereduceerd kunnen worden tot de locale economie.

Meester vindt dat wel gebruik gemaakt moet worden van externe informatie van het CPB die de scenario's al heeft ontwikkeld. Maar, constateert hij, er heerste een beheerscultuur waarbij de ministeries dachten dat, door uit te gaan van de CPBscenario's een gezamenlijke ondergrond zou ontstaan. Van Latesteijn vindt dat bij de beleidsscenario's, waarin het 'willen' centraal staat, een gezamenlijk gebruik van de CPB-scenario's wel logisch is. Schuring is van mening dat de CPB-scenario's geen normatieve scenario's zijn maar voorstelbare economische groeipercentages.

Van Latesteijn is het hiermee eens zolang de bandbreedtes van de CPB-scenario's als enige gebruikt worden bij inschatting van de mogelijke spreiding in de omgeving. Zodra echter de uitkomsten van de scenario's van economische groei op nationaal of sectoraal niveau overgenomen worden, dan is de stelling dat er geen sprake is van beleid niet te handhaven.

Meester merkt op dat een vervlechting bemoeilijkt wordt omdat het spanningsveld tussen 'willen' en 'kunnen' ontzettend groot is, zeker omdat binnen rijksoverheidsdiensten er zoveel 'willen' is.

Sakkers ziet als moeilijkheid bij vervlechting en ontvlechting in een verkenning dat een minister zich gelijktijdig moet profileren met beleid, visionair moet zijn, en zich moet bezinnen op de mogelijke toekomsten waarbij wenselijkheid meer naar de achtergrond verplaatst zou moeten worden en de mogelijkheid meer naar de voorgrond. Men moet goede afspraken maken om onderzoek van beleid te scheiden, dat is bijvoorbeeld te weinig is gebeurd bij minister De Boer.

\subsubsection{STELLING 2: OVERDRACHT AMN ANDERE BELEIOSONDERDELEN}

Van Latesteijn introduceert de tweede stelling: doordat er geen duidelijke methode was ontwikkeld om de mogelijke toekomstbeelden over te dragen aan andere beleidsonderdelen van het ministerie, is het project Questa slechts half geslaagd. In aansluiting daarop vraagt hij hoe de opdrachtgevers naar de opdrachtformulering van het project hebben gekeken. Schartman antwoordt dat hij alleen 
op het moment dat de kern van het product er lag, betrokken is geweest bij de overdracht. Er is een aantal oorzaken aan te wijzen waarom de overdracht niet goed verlopen is: Questa werd op een gegeven moment onderbroken omdat een signaal kwam van de top dat het wel erg open was. Bij Questa is er minder zichtbaar door de minister ingegrepen dan bij 2030. Een tweede reden is volgens Schartman misschien dat de verkenners er vrij goed in geslaagd zijn om beleidsarme omgevingsscenario's te maken. Het vertalen naar beleid is waarschijnlijk daarom problematisch geweest. Schuring is het met stelling twee eens: er is in Questa in eerste instantie getracht te ontvlechten en daarna te vervlechten. Dat laatste zou door anderen moeten gebeuren.

Keijts is van mening dat om een slechte overdracht te voorkomen, die overdracht van tevoren besproken en vastgelegd had moeten worden. Bij Shell moesten bijvoorbeeld alle managementteams in het eerst volgende directieplan laten zien wat ze gedaan hebben in termen van beleid naar aanleiding van de uitkomsten van de scenario's. Dit is bij Questa niet gebeurd omdat er organisatorisch veel veranderingen zijn geweest en veel wisselende opdrachtgevers. Bovendien is er een hoog gehalte aan eigenwijsheid in de organisatie. Keijts vindt Questa daarom helemaal niet mislukt. "Het was de eerste keer dat een heel moeilijk 'volk' geleerd heeft om bewust om te gaan met een aantal onzekerheden."

Dikmans vindt ook dat Questa maar half geslaagd is, maar vooral omdat het traject van de 'wils' bepaling (de Perspectievennota) voor een groot deel als bijna voltooid gezien werd en er weinig bereidheid was om Questa nog te gebruiken. Bovendien zijn er mensen vertrokken, en dus ook kennis, en is er te weinig geïnvesteerd in het 'verkopen' van de producten van Questa. Het opmerkelijke is dat in de relatief beleidsveilige omgeving van Rijkswaterstaat er wel buitengewoon veel gebruik van gemaakt is.

\subsubsection{STEUING 3: MOEIZAME VERVLECHTING IN HET NIEMANDSLAND}

Van Latesteijn introduceert de laatste stelling: “de ambitie tot vervlechting was in de praktijk maar zeer moeilijk tot ontwikkeling te brengen omdat deze zich bevindt in het niemandsland tussen het aandachtsgebied van de onderzoekers en het verantwoordelijkheidsgebied van de beleidsmakers."

Schuring merkt hierover op dat het misschien een denkfout is geweest om de opdracht voor het projectteam te beperken tot het maken van de scenario's en het vervolgens aan anderen over te laten hoe die gebruikt zouden worden. Maar ook de cultuurverschillen tussen degenen die het beleid ontwikkelen en degenen die de scenario's maken, kunnen een oorzaak zijn geweest voor een moeizame vervlechting. Hij ziet het spanningsveld tussen 'wenselijk' en 'mogelijk' niet zomaar verdwijnen als er nieuwe professionele ambtenaren komen tussen beleid en onderzoek in. Schuring vindt de verkenningen uitdrukkelijk ook een beleidsmiddel voor 
de medewerkers. Hij is van mening dat bij een spoor van twijfel bij beleidsmakers over beleid en sturing, de scenario's goed gebruikt kunnen worden. Maar als de wilsvorming duidelijk is, dan is de toepassing van de toekomstverkenning moeilijk. Scenario's moeten relevant zijn voor de toekomstige gebruikers.

Verroen is van mening dat de verkenners dichter bij een aantal beleidsthema's moeten gaan zitten en een brug moeten slaan naar discussies over marktwerking, prijsbeleid, openbaar vervoer, de onderwerpen waar de politieke discussies op dat moment over gaan. Als hij even de advocaat van de duivel speelt dan kunnen scenario's gebruikt worden voor Kwaliteit of voor Acceptatie; dus voor toetsing van beleid of communicatie over beleid. Verkeer en Waterstaat lijkt beide niet op te pakken: het ministerie gaat niet door op scenario's voor de kwaliteitsverbetering, maar ook niet om de interne discussie los te maken. Tot slot merkt Verroen op dat, door een expliciet besef dat er een intern proces gaande is, er een soort veiligheid ontstaat om je denkraam op te rekken. Het reduceren van onzekerheden is onzin in scenario's.

Saris werpt de vraag op of dezelfde organisatie in staat is om beleid uit te voeren en dat intern ter discussie te stellen. Schartman is van mening dat de vervlechting wel mogelijk is binnen één organisatie maar dat weinig resultaat behaald wordt als het management het er niet mee eens is. Organisatorische veranderingen en de houding van het management kunnen hierin wel verandering brengen. Een organisatie moet het aandurven om een spiegel voorgehouden te krijgen en met onzekerheden te leven.

Sakkers merkt op dat de persoonlijkheid van de opdrachtgever een belangrijke rol kan spelen. De Boer stelde zich bij Nederland 2030 bijvoorbeeld in het begin procedureel op. Schartman sluit hierbij aan en is van mening dat de minister en de manier van organiseren natuurlijk van invloed zijn, maar dat er ook intern een cultuur kan zijn (met een welwillend ambtelijk management) waarin voortdurend in opties en robuustheid gedacht wordt. Als dat goed gaat heeft iedere bewindspersoon daar voordeel bij.

Meester heeft nog twee opmerkingen: in stelling drie wordt gesproken van onderzoekers en beleidsmakers, terwijl het vaak dezelfde personen zijn. Daarnaast denkt hij dat het vertrouwen in de bewindspersoon inderdaad van groot belang is voor het verloop van het onderzoek.

Keijts vindt een kritisch aspect dat de gebruikers van de scenario's in het traject van het maken van de scenario's betrokken worden. Zij moeten niet feitelijk meehelpen aan het bouwen van die scenario's. De onzekerheden waarmee beleidsmedewerkers zitten moeten wel boven tafel komen. Hij is van mening dat de verkenningen die om kwaliteitsverbetering gaan beter intern in een ministerie gehouden kunnen worden, omdat er veel spelers in het spel zijn en het om politiek gaat. Door te vragen naar de toekomst bij beleidsmakers komen juist onzeker- 
heden naar boven. Saris meent dat dit, bijvoorbeeld voor een bestuursraad, een ongewenst product is. Zij wil geen onzekerheid en ook geen beleidsconcurrentie. $\mathrm{Zij}$ wil gewoon dat een nota wordt afgeleverd als een minister een nota wil. Als iedereen over het beleid gaat meepraten, dan ontstaat er onzekerheid. Van Latesteijn is van mening dat er geen goed beleid gemaakt kan worden als de onzekerheden impliciet blijven.

Van Latesteijn vat het geheel samen en concludeert dat er ergens iemand nodig is die voortdurend die scharnierfunctie tussen verkenningen en beleid bemant. Daar moet bovendien continuitteit inzitten. Er is al veel ervaring opgedaan op dit gebied, maar echte bedrevenheid is er wellicht nog niet. Schuring constateert dat er wel al heel veel kinderziektes zijn onderschept en dat er sprake is van vooruitgang op dit gebied. 


\title{
8 PLeNAIRe discussie
}

\author{
Discussieleider: \\ Dhr. Saris (De Stad B.v., projectsecretaris) \\ Panelleden: \\ Dhr. Lammers (NVK 97), Dhr. Rutjens \\ (Woonverkenningen), Dhr. Schuring (Questa), \\ Dhr. De Jong (NL 2030), Mw. Grijzen (Brabant 2050), \\ Mw. Van Herwaarden (Landbouwverkenningen Noord- \\ Brabant), Dhr. Teisman (EUR/KUN en Bestad).
}

\section{Opening}

Saris stelt de panelleden voor. Allen zijn opdrachtnemers van afgelopen verkenningen. Hij vraagt naar opvallende leerervaringen uit hun werkgroepdiscussies van vanmiddag.

De Jong (Nederland 2030) reageert als eerste. Hij vond een belangrijke leerervaring van Frieling (TU Delft) komen, die wil naast 'weten', 'willen' en 'kunnen' ook 'doen' benoemen. De verkenningen moeten gaan over de agenda, investeringen, projecten en de activiteiten die in beleid kunnen worden voorgenomen. Bovendien zou het 'doen' een goede gespreksgrond zijn voor het 'willen' en 'kunnen'.

Voor Rutjens (Woonverkenningen) was een leerervaring dat verkennen betekent dat de politiek nog even geen keuzen moet maken. De politiek moet afstand houden maar wel de faciliteiten bieden om de voorkeuren in de samenleving te inventariseren. Voor de Woonverkenningen werd de slaagkans groter omdat Tommel heeft gewacht om een standpunt in te nemen.

Grijzen (Brabant 2050) geeft aan dat bij Brabant 2050 het omgekeerde is gebeurd. De basis van het ambtelijk apparaat en het Provinciaal bestuur hebben zich gecommitteerd aan Brabant 2050,.ondanks dat het geen bestuurlijk document was. Daarna is de communicatie aangegaan met de Brabanders. Die communicatie creëerde verwachtingen van het provinciale apparaat, maar zij hebben nog niet helemaal de goede houding om aan die verwachtingen te kunnen voldoen. De implementatie in de organisatie had meer aandacht nodig gehad.

Van Herwaarden (Landbouwverkenningen Brabant) heeft als leerpunt dat dit soort projecten tussentijdse en regelmatig terugkerende momenten van reflectie nodig hebben. Niet alleen met mensen van de eigen organisatie maar ook met externen om te voorkomen dat het collectieve geheugen vernietigd wordt. Een moeilijk punt vindt zij ook de koppeling van het maatschappelijke, bestuurlijke en ambtelijke.

Lammers (NVK) herkende in de 'Terugblik op toekomstverkenningen' dat de NVk 97 getypeerd werd als klassieke benadering met weinig interactie tussen beleid en onderzoek, sterk gericht op het 'weten'. De ontvlechting van beleid en onderzoek is 
in de NVK tamelijk procedureel tot stand gekomen. In een volgende verkenning kan dat misschien wat meer open gegooid worden. Hij heeft als leerpunt dat er veel manieren zijn om te verkennen. Maar het is nog niet duidelijk wat de beste manier is. Ook zou meer nagedacht moeten worden over het onderscheid tussen het 'willen' van een politicus, het 'willen' van een verkenner en het 'willen' van een maatschappij.

Schuring (Questa) vindt dat binnen v\&w al veel geleerd is over het hanteren van verkenningen, maar dat er nog veel te leren valt om dit in grote successen om te zetten. Zo lijkt het verstandig om in het voortraject het 'kunnen' en 'willen' (mogelijke versus wenselijk) te ontvlechten. Het is wel een probleem om dat voor elkaar te krijgen. Bovendien moeten zij uiteindelijk ook weer vervlochten worden. Schuring is van mening dat van een professionele (beleids)organisatie verwacht mag worden dat er reflectie wordt ingebouwd om het wenselijke ook aan het mogelijke te koppelen, zodat de kwaliteit van het wenselijke verbeterd kan worden. Een leerpunt is dat in een succesvolle vervlechting een aantal condities een rol spelen: bijvoorbeeld ruimte van een bewindsvoerder. Daarover moet nog meer geleerd worden.

Na deze eerste ronde leerpunten introduceert Saris een drietal thema's dat ook in de 'Terugblik op toekomstverkenningen' en in de werkgroepdiscussies aan de orde is gekomen:

1 Vervlechting: hoe doe je dat goed in het proces en wat is de rol van opdrachtgevers?

2 Verhouding maatschappelijke discussie en verkenning.

3 Leercapaciteit en hoe continuïteit daarin te brengen.

\section{Vervtechting}

Schuring is van mening dat bij Questa methodisch goed nagedacht is over het gescheiden ontwikkelen van wenselijke en mogelijke toekomsten. Een probleem diende zich aan toen de mogelijke toekomsten als een testruimte moesten gaan dienen voor de wenselijke toekomst. Een aantal platvloerse redenen voor dat probleem is dat mensen die aan de mogelijke toekomsten hebben gewerkt, vertrekken om iets anders te gaan doen. Of omdat de mensen die aan het 'willen' werkten (Perspectievennota en NVVP) het lastig vonden om nog een ander project daarbij te betrekken. Een derde reden kan zijn geweest dat het 'willen' in de Perspectievennota al zoveel vorm had gekregen dat er geen behoefte meer was aan reflectieve instrumenten. Wellicht is het beter om de mogelijke toekomsten in het proces van 'wils' ontwikkeling te integreren.

Keijts (opdrachtgever Questa) vindt het een gemiste kans dat Questa niet gebruikt is om het NVvP te toetsen. Schartman ( $\& \& w, s$ en $C$ ) denkt dat de mogelijke toekomstbeelden in de scenario's misschien wel "te goed" waren. Zij leverden een andere 'wereld' dan de beleidswereld was. In een beleidswereld worden stand- 
punten onderbouwd. Daarin is niet zoveel behoefte aan verschillende omgevingen die argumenten relativeren.

Den Dunnen (opdrachtgever NL 2030) is van mening dat in de praktijk ontvlechting niet werkt. De theoretische scheiding van 'willen', 'weten' en 'kunnen' is niet echt mogelijk. Het gaat om de mate van ontvlechting en vervlechting in verschillende fasen en met name om het bewustzijn dat de verhouding tussen beleid en onderzoek in verschillende fasen anders ligt. Teisman sluit hierbij aan en is van mening dat de richting van absolute ontvlechting niet mogelijk is. Er zou misschien een onderscheid gemakkt kunnen worden tussen cognitieve ontvlechting en sociale vervlechting. Ontvlechting is nodig om de ruimte te scheppen waarin nagedacht kan worden, en waarin ook dat wat in conflict is met de beleidsorganisatie uitgesproken kan worden. Tegelijkertijd moet er een scherpere vervlechting zijn van alle kokers, lagen en beleidsgremia die betrokken zijn bij beleidsontwikkeling.

Schuring heeft een aantal sheets meegenomen waarin de fasering van vervlechting en ontvlechting te zien is:

\section{Figuur 6}

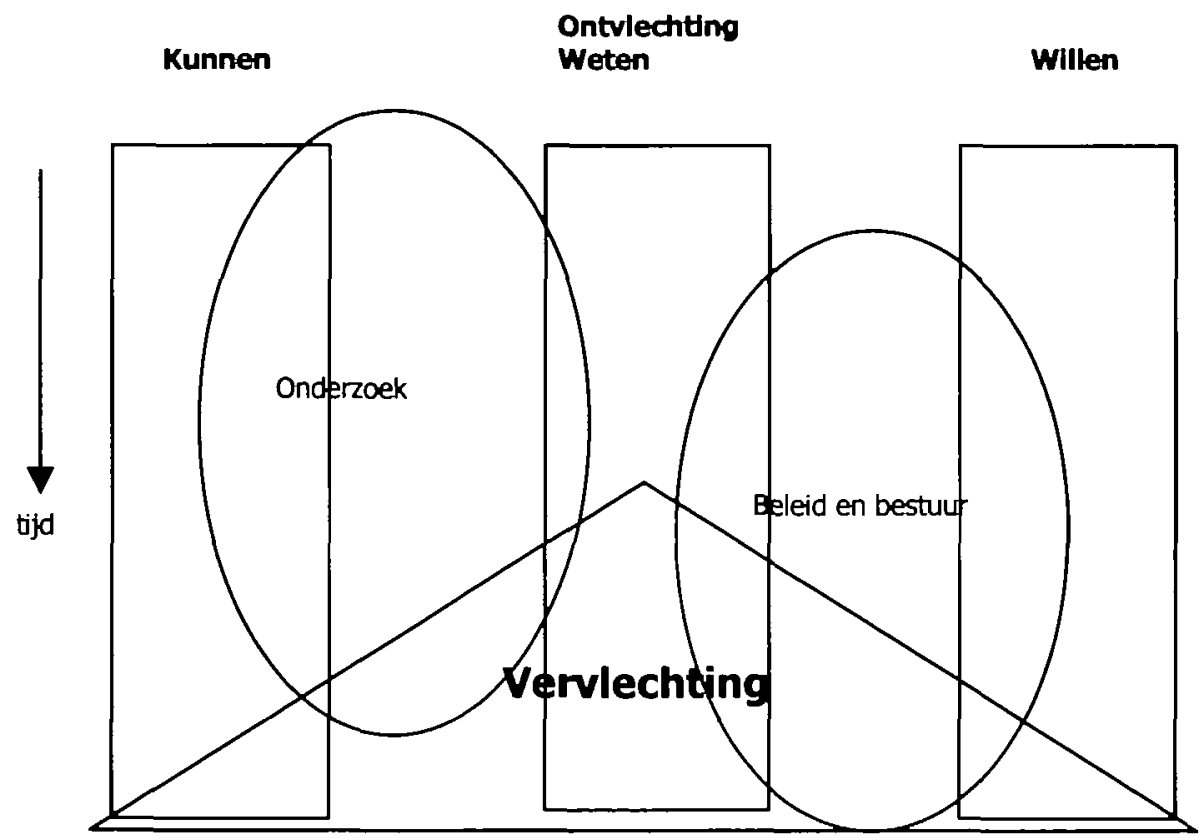


Figuur 7

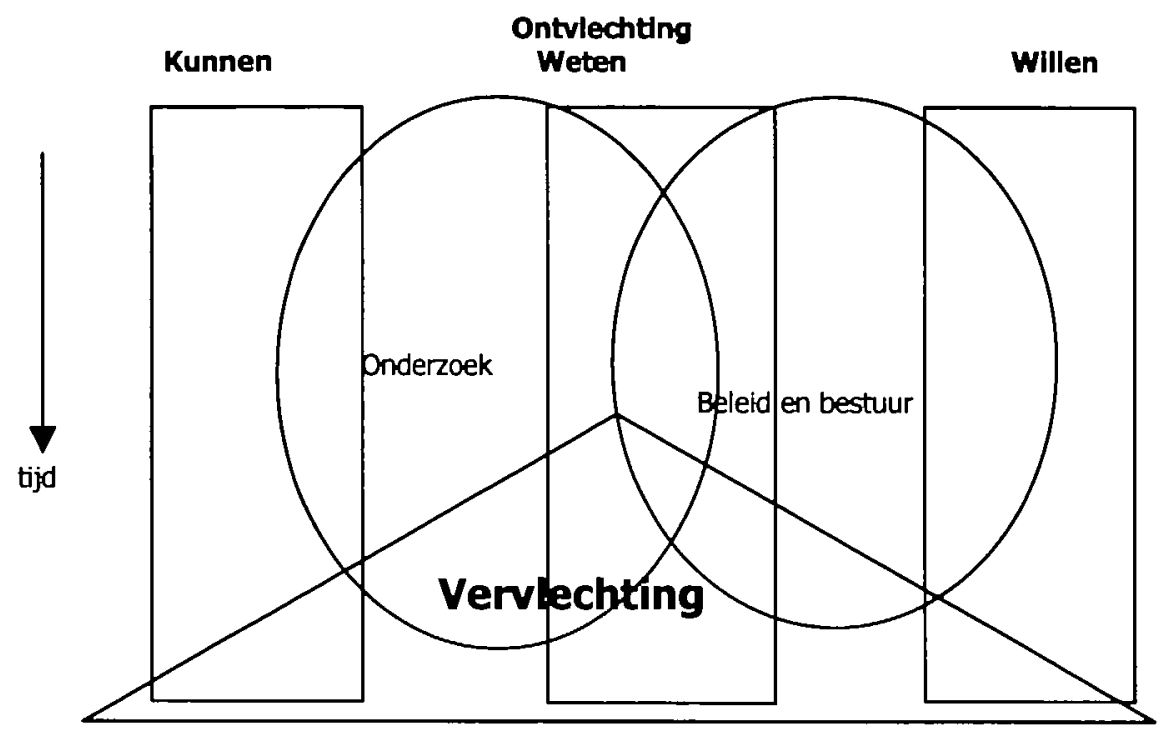

Volgens Schuring is tijdsfasering belangrijk in vervlechting en ontvlechting. Verkenners beginnen met het onderzoeken van feiten en mogelijkheden maar niet met de wensen. Aan de beleids- en bestuurskant worden de wenselijke ontwikkelingen bepaald. De vraag is hoe de verzameling van kennis met de 'wils' formulering vervlochten kan worden. Volgens Schuring gaat op dat moment het meeste mis en is er dus ook het meeste te leren. Hij denkt dat de ontvlochten onderdelen alleen bij elkaar kunnen komen als daar al in de beginfase over nagedacht is.

Frieling reageert op het schema en zou bij de kolom 'weten' de onderzoekers plaatsen, bij de kolom 'kunnen' zet hij ontwerpers, en bij 'willen' het beleid en bestuur. Er zijn drie groepen van deskundigen en een vierde groep van mensen die het moeten doen, de 'uitvoerders'. Deze laatste zijn bijvoorbeeld een bestuur en de beleidsuitvoerders. Politieke en maatschappelijke groepering 'willen' iets. De onderzoekers leveren daarbij waarschijnlijke toekomstbeelden en de ontwerpers mogelijke of onwaarschijnlijke toekomstbeelden.

Den Dunnen vindt het schema erg verhelderend maar is van mening dat de tijdsas voor het 'willen', 'weten' en 'kunnen' nooit hetzelfde is. Met name de 'willen'-as is een normatieve as en daar ligt het maatschappelijk debat op dat soms verdichting kent in de tijd. Dat was ook de reden dat M. de Boer zich heeft uitgesproken: zij zat in een normatief debat. 


\section{Maatschappelijk debat en vervlechting}

De Jong vindt dat de mate van vervlechting en ontvlechting afhangt van het doel van de verkenning. Nederland 2030 was bijvoorbeeld een verkenning die beoogde veel gedachten en gedrag te beinvloeden. Dan hoeft er niet ontvlochten te worden, maar moet juist zo interactief mogelijk met veel mensen nagedacht worden over wensen, feiten en mogelijkheden. Dat is anders bij verkenningen die simpelweg willen zien hoe de verkeersintensiteit zich ontwikkelt en welke beleidsmaatregelen daarvoor nodig zijn. De richting en het doel van de verkenningen moeten in deze discussie betrokken worden.

Rutjens is het hiermee eens. In de Woonverkenningen was de eerste zin dat de toekomst noch gekend, noch gemaakt kan worden. Met de Woonverkenningen werd geprobeerd om maatschappelijke organisaties te inspireren andere beslissingen te nemen. De verkenningen hadden het doel om maatschappelijke debatten op gang te krijgen en om duidelijk te krijgen wat de maatschappelijke vraagstukken zijn die spelen bij al die actoren die het woonbeleid willen beïnvloeden. Dat zou een mogelijke agendering moeten leveren, waaruit de politiek heldere keuzen zou kunnen maken.

Saris vult dit aan met de opmerking dat op dit punt de verkenningen van elkaar verschillen. De NVk en Questa hadden, bijvoorbeeld, dat doel niet. Hij stelt daarna de vraag wat de voorwaarden zijn, om op basis van toekomstverkenningen een maatschappelijk debat te kunnen voeren. Een eerste voorwaarde is, volgens Saris, politieke vrijheid over de inhoud. De politiek moet vooral het proces sturen. Volgens Rutjens is een tweede voorwaarde dat het onderzoek zich beperkt tot de keuzen die voorliggen en die niet gaat vervlechten met mogelijke oplossingen. Als dat wel gebeurt dan wordt gekozen uit mogelijke of wenselijke toekomsten. Daarmee pretenderen de onderzoekers ook dat die keuzen maakbaar zijn. In de Woonverkenningen is daarom uitdrukkelijk niet gekozen om een aantal eindbeelden te formuleren. De Woonverkenning is wel geëindigd met een agendering van het maatschappelijk debat. Uiteindelijk hebben de verkenningen altijd tot doel om mogelijke keuzen voor nieuw beleid voor te leggen of, bijvoorbeeld, om een interne organisatie aan te passen.

Het Brabant Manifest is volgens Grijzen net als de Woonverkenningen ingezet om een maatschappelijk debat te voeren. En op basis daarvan te werken aan structurele problemen van vandaag waar steeds deeloplossingen voor werden bedacht, bijvoorbeeld in de Nadere Uitwerking van de vINEX met de vijf grote steden in Brabant. Die discussies verliepen vanwege de onderlinge concurrentie moeizaam. Gaandeweg kwam steeds bovendrijven dat er meer aan de hand was. Om de fantasie te prikkelen en nieuwe oplossingen te kunnen verzinnen zijn twee utopieën ontworpen en is Brabant 2050 van start gegaan. De idee was om de toekomst niet langer als het opgeloste heden te zien. De maatschappelijke discussie kon op grote schaal en met anderen dan professionals gehouden worden. Er waren allerlei organisaties bij betrokken uit het bedrijfsleven, kennisinstituten en maatschappe- 
lijke organisaties. Van Eenbergen vult aan dat er, na het volbrengen van het Manifest, ook nog twee jaar de tijd genomen is om een breder debat te voeren. Daar zaten niet dezelfde mensen aan tafel als bij het produceren van het manifest. De politiek heeft het vierjarige proces de ruimte heeft gegeven. Thönissen (Provincie Brabant) was deelnemer aan het proces in Brabant. Hij vindt dat het proces al bewijst dat het mogelijk is om met veel verschillende actoren een debat over de toekomst te voeren. Er is daar wel een duidelijke doelstelling bij nodig. Het Manifest was ook bedoeld om draagvlak te creëren. Er is getracht om verbanden te zoeken tussen de politieke visies en de maatschappelijk agendering. Dat was ook het belangrijkste resultaat: “je kunt werken aan beelden maar als je niet tegelijkertijd draagvlak hebt dan lukt het niet". Saris merkt op dat het misschien geen draagvlak creëren was, maar meer het rijp maken van de geesten rijp voor innovatie.

Schuring is het ermee eens dat, als het doel van de verkenningen is om het wenselijke in beeld te krijgen, er niet met een klein intern clubje toekomstbeelden gegenereerd moeten worden. Maar, als het doel is de kwaliteit van de beleidsontwikkeling te verbeteren dan kan dat, volgens hem, zeker wel intern gebeuren. De Jong merkt hierover op dat dit een uitspraak is met een achterliggende sturingsfilosofie van wat beleid vermag. In zijn opvatting spelen er altijd meer actoren een rol in het denken over de toekomst, ook als het gaat over professioneel ambtelijk handelen of de wilsvorming. Het beleid is decentraal van karakter, dat wordt van onderaf opgebouwd en van bovenaf wordt getracht dat wat te sturen. De Jong vindt het niet reëel om te denken dat je een nationaal debat over ruimtelijke ordening heel intensief kunt voeren. In NL 2030 hebben vooral vakgenoten en bij het onderwerp betrokken bestuurders deelgenomen aan de discussies. De ambitie was wel om veel actoren aan de gang te zetten om na te denken over de toekomst. Dit proces is naar zijn idee niet door de stellingname van de minister gefrustreerd. Volgens Lever (VROM) kwam dit omdat de minister steeds uitdrukkelijk heeft vermeld dat zij benieuwd was naar de voorkeuren van de deelnemers. De conclusies van de discussies over Nederland 2030 waren ook heel breed en genuanceerd.

Saris vraagt aan Teisman of het maatschappelijk debat een belangrijke rol speelt in het op gang brengen van een innovatie door beleidsmakers, en of dit het vervlechten van 'willen', 'weten' en 'kunnen' is. Teisman antwoordt dat een verkenning bijna nooit ingezet wordt omdat beleidsmakers of politici niet 'weten', maar bijna altijd omdat partijen iets 'willen'. Dat 'willen' moet verbeterd worden met behulp van de verkenning. Ook worden verkenningen ingezet omdat partijen iets willen 'kunnen' en dat 'kunnen' ook willen verbeteren. Een groot deel van de verkenningen wordt ingezet omdat iedereen 'weet', maar wel allemaal een stukje. Met de verkenning worden de stukjes bij elkaar gebracht. Het interessante van het maatschappelijk debat is dat burgers de beste experts zijn in het meer ontkokerd denken, ze denken misschien ook wel lokaal beperkt, maar in dat opzicht is er een belangrijke bron van kennis, van 'weten' bij iedereen. Dit zou impliceren dat elke ambtelijke organisatie en elke bestuurder, om zelf beter te kunnen 'willen', juist 
ook die partijen in het debat zou willen hebben. Zodat niet wederom een hele sterke ingroup van beleidsmakers en bestuurders de eigen waarden herbevestigt.

Saris vraagt of door deze vervlechting niet erg ver van de wetenschap wordt afgedreven. Teisman merkt hierover op dat hij er niet vanuit gaat dat wetenschappers op voorhand beter 'weten' dan anderen, of dat politici op voorhand beter 'willen' dan anderen, en dat ontwerpers beter 'kunnen' dan anderen. Daarom gaat het echt om de vervlechting.

Van Latesteijn (WRR) vindt het op deze manier teveel een pudding worden. Er liggen wat hem betreft verschillende verantwoordelijkheden. In de discussie over Questa bleek dat het niemandsland in de vervlechting: tussen 'willen, weten kunnen' juist gevuld moest worden door professionals, die misschien tussen onderzoekers en beleidsmakers in zitten. Het project T\&o is weggestuurd met een beetje te simpele vraag: hoe de kloof te overbruggen. Het blijkt nu dat er op sommige momenten juist specifieke informatie nodig is, en dat op andere momenten die soorten kennis met elkaar in verband moeten worden gebracht. Het interessante van, onder andere, scenariostudies is dat daarmee normatieve voorkeuren onderzoeksmatig naast elkaar gelegd kunnen worden. De 'objectief' verkregen wetenschappelijke informatie kan in scenario's op zijn consequenties in een normatieve setting onderzocht worden. Als beleidsprofessionals dit zouden kunnen ontwikkelen, dan zou iets van het vraagteken over het niemandsland tussen beleid en onderzoek kunnen verdwijnen. Als dit eventueel door een interdepartementaal apparaat uitgevoerd zou worden, dan zou dat apparaat daar wel de ruimte voor moeten krijgen.

Tommel (Nationale Woningraad, voorheen VROM) merkt hierover op dat de afstand en ruimte er alleen kunnen zijn als de opdrachtgever vertrouwen heeft in het ambtelijk apparaat. Anders worden de vooropgestelde politieke grenzen door niet expliciet uitgesproken ambtelijke grenzen vervangen. Hij is van mening dat een verkenning kan 'landen' als er zoveel mogelijk meningen, waarschijnlijkheden, kennis van buiten af, van anderen betrokken worden. De politiek moet in die fase als een spons werken, er is geen onderhandeling. Het inventariseren moet in het proces eerst georganiseerd worden. Daar moet de politiek zich nog niet in mengen.

Saris vraagt of de ontvlechting, de scheiding tussen politieke sturing, het onderzoek en het maatschappelijk debat groter gemaakt moet worden door bijvoorbeeld binnen VROM een grotere afstand tussen het planbureau en anderen te creëren. Versnel (Vereniging Natuurmonumenten) wil wel een onderscheid tussen de planbureaufunctie enerzijds en de beleidsfunctie anderzijds. De maatschappelijke opvattingen en gedachtegangen moeten inderdaad geïnventariseerd worden, ook in een onderzoeksfase. Hoe weinig wetenschappelijk de opvattingen zijn, dat is niet relevant in dit onderzoek. Teisman merkt op dat zowel Tommel als Versnel vanuit het hiërarchisch model redeneren, waarin verkenners niks willen maar uiterst open en loyaal de kennis verzamelen voor anderen, ten bate van de keuzen 
van anderen. In zijn waarneming wordt juist vaak gezegd, als het gaat om de politieke wilsbeschikking en nadat beleid en onderzoek ontvlochten zijn, dat die kennis net niet nodig was. Om dat te voorkomen, en dat zal nodig zijn in een netwerksamenleving, moeten de processen anders georganiseerd worden, aldus Teisman.

\section{Leercapaciteit van een organisatte en continuiteit}

Over het derde thema wordt kort gesproken. Saris merkt hierover op dat het effect van een verkenning niet alleen binnen een organisatie bekeken moet worden, maar ook in de omgeving. Allerlei partijen gaan met de ideeën aan de gang. In de expostanalyse is daar nog niet naar gekeken. Ook het effect van de interne overdracht viel buiten het onderzoeksterrein van de 'Terugblik op toekomstverkenningen'.

Grijzen merkt op over het Manifest 2050, dat een ambtelijke organisatie moeilijk á la minuut adequaat kan inspelen op een proces dat incrementeel en spontaan van start is gegaan. De politiek heeft er ook voor gekozen om eerst de discussie aan te gaan en pas daarna zelf te reageren. $\mathrm{Zij}$ is van mening dat het succesvol reageren niet alleen iets met de politieke wil te maken heeft, maar ook met een houding van een organisatie: hoe met dingen wordt omgegaan. Dat kan een probleem zijn in een organisatie. Saris stelt naar aanleiding hiervan de vraag of een management zou moeten leren dat er verrassingen uit een proces komen waar een organisatie rekening mee zou moeten houden. Grijzen vraagt zich af of daar wel op voor te bereiden is. Het enige is dat een ambtelijk apparaat bereid moet zijn om te zien wat er gaat gebeuren en daar mee om te gaan.

\section{De leerervaringen van de panelleden in deze discussiemiddag}

Saris vraagt ieder panellid naar de leerpunten voor het vervolgtraject van het project T\&O.

Lammers (NVK '97) heeft vooral de behoefte om naar de doeners te kijken, zodat de abstracte discussie van vanmiddag te vertalen is naar iets dat te realiseren is. Hij ziet in ontwerpende toekomstverkenningen de mogelijkheid om de relatie met de bestuurders te leggen.

Schuring (Questa) wil meer aandacht voor de voorzieningen die getroffen moeten worden om de ontwikkelde 'mogelijke' toekomstbeelden meer ten dienste te maken aan het verbeteren en formuleren van de wenselijke beelden.

Rutjens (Woonverkenningen) ziet veel discussiepunten uit de Woonverkenningen terug in discussies van gemeenten en corporaties. De intentie om een aantal ontwikkelingen op de agenda te zetten is geslaagd. Hij is tevreden en zou de verkenningen niet anders willen doen. 
De Jong zou drie dingen anders willen doen: voordat begonnen wordt meer investeren in interdepartementale betrokkenheid bij het hele proces. Ten tweede zou hij trachten de rijkdom aan ideeën zo goed mogelijk behouden, zoals die er halverwege het traject van NL 2030 was. Tot slot zou hij vooral een onderscheid maken tussen de enerzijds de proceskanten van het ruimtelijke ordeningsbeleid, dus wat is de sturingsfilosofie en welke actoren zijn betrokken, en anderzijds het kaartbeeld dat erbij geschetst is.

Grijzen vindt een leerpunt dat de rollen van iedereen in ieder proces helder moeten zijn. Een bestuurder moet besturen maar moet ook weten wat de achterban verlangt van zijn bestuur. Veel beroepspolitici zijn vakinhoudelijk of bestuurlijk goed, maar weten vaak niet zo goed wat de bestuurden van hen verlangen. Het vergt politieke moed om die garbage can van wensen, mogelijkheden en beperkingen ook te onderzoeken. Vervolgens zijn ook instrument nodig om dat te kunnen doen. Daar moet meer in geïnvesteerd worden.

Van Herwaarden vindt dat er voldoende aandacht moet zijn voor de vertaalslag van de scenario's naar beleidsopties. Bovendien moet er door de Provincie meer belang gehecht worden aan externe initiatieven. Met name het management zou meer belang moeten hechten aan het belang van het proces en het toekomstgericht denken.

Saris concludeert dat:

- De panelleden belang hechten aan het proces en het netwerk in de maatschappij. Dat daarvoor moedige politici nodig zijn die niet alles zelf willen te doen, maar de verkenners wel steunen in het verkennen van de toekomst.

- Dat verkenningen interdepartementaal strategisch ingezet kunnen worden om meer effect te hebben op, bijvoorbeeld, procedures die er zijn (bijv. ICES).

\section{J. Bouma (voorzitter van de stuurgroep) sluit de plenaire blfeenkomst af met tien opmerkingen}

Op basis van de 'Terugblik op toekomstverkenningen', de stellingen en wat er vanmiddag hier besproken is, is een aantal conclusies geformuleerd.

1 Systematische ex-postanalyses van toekomstverkenningen van deze aard kunnen behulpzaam zijn als leerervaring bij het effectiever maken van toekomstonderzoek. Een beoordeling van de zes verkenningen in algemene zin is moeilijk omdat de verkenningen zeer verschillend zijn, ook qua doelstelling. Discussies worden nog te exclusief gevoerd tussen betrokkenen bij bepaalde verkenningen.

2 Uit de zes studies blijkt dat het beeld van een kloof tussen beleid en onderzoek te beperkt is . Er is eerder sprake van sterk variërende vormen van vervlechting en ontvlechting in de tijd. Periodieke ontvlechting kan nuttig zijn voor reflectie. Vervlechting wordt veelal gezien als een belangrijke voorwaarde voor het scheppen van een maatschappelijk draagvlak voor de verkenningen en beleidsopties. 
3 Schetsen van de toekomst stoelen vaak primair op sectorale beleidsoverwegingen, ook al worden breder gefundeerde schetsen in eerste instantie vaak wel nagestreefd. Inzet van meer externe deskundigheid en het verhogen van interdepartementale betrokkenheid is daarom aan te bevelen.

4 Het tijdens de analyse op ondoorzichtige wijze mengen van wenselijke ('willen'), mogelijke ('kunnen') en waarschijnlijke ('weten') toekomstbeelden, leidt tot onduidelijkheid. Systematisch onderscheid tussen deze drie benaderingen wordt daarom als zinvol ervaren. In welke sequentie en op welke wijze deze beelden worden beschouwd is sterk afhankelijk van de aard van de verkenning en van de gekozen beleidsbenadering.

5 Exclusieve accenten op relaties tussen onderzoek en beleid ontkennen de belangrijke rol van de stakeholders, zoals deze in tenminste vier van de zes studies naar voren komt. Deze rol moet structureel worden ingebouwd, ook al zal dit de complexiteit van studies vergroten omdat ook hier het 'willen', 'kunnen' en 'weten' een rol spelen. Een brede betrokkenheid van stakeholders lijkt alleen nodig en functioneel, als het vergroten van het maatschappelijk draagvlak het primaire doel is.

6 De aard van het verrichte onderzoek blijft in de gegeven analyses ten onrechte onderbelicht. Toekomstonderzoek is wezenlijk anders dan klassiek onderzoek waar het: 'gegeven-te bewijzen-bewijs' regeert. Is toekomstonderzoek projecterend, verkennend of voorspellend? Is het rationeel-analytisch of ontwerpend? Maakt het creatief gebruik van bestaande gegevens of formuleert het * witte plekken" die alleen met nieuw innovatief onderzoek kunnen worden ingevuld? En is dit mogelijk? Wat is de rol van ICT?

7 Onafhankelijk onderzoek dat op zichzelf staat, of dat is gebaseerd op een duidelijk omschreven opdracht vanuit het beleid, lijkt voor beleidsinnovatie soms meer effect te hebben dan strikt beleidsgebonden en -afhankelijk onderzoek of onderzoek dat op ondoorzichtige wijze door het beleid wordt aangestuurd.

8 De zes verkenningen hebben alle op verschillende, en soms onvoorspelbare manieren, geleid tot verbeterde communicatie tussen beleid, onderzoek en burgers. Soms is de communicatie zelfs door het onderzoek voor het eerst tot stand gebracht. Verkenningen zijn echter slechts een eerste stap. Concrete beleidsplannen vereisen een voortbouwen op het gelegde fundament, waarbij idealiter de betrokkenen hun activiteiten concreet voortzetten. Het gebleken gebrek aan continuiteit van personeelsinzet en het te weinig penetreren van resultaten in de organisatie leidt tot inefficiëntie. Formele koppeling van verkennings- en beleidsprojecten verdient daarom aanbeveling (bijv. Questa en het Nationaal Verkeer- en Vervoersplan; de Natuurverkenningen '97 en het Natuurbeleidsplan, de Landbouwverkenningen en het Brabant 2050 in Brabant en het streekplan, en Nederland 2030 en de Vijfde Nota).

9 Wenselijke interacties tussen onderzoek en beleid kunnen door hun grote diversiteit niet in standaardrecepten worden gevangen. Wel kunnen op grond van voorbeeldstudies, zoals hier gepresenteerd, belangrijke keuze-, beslis- en kantelmomenten in de interactieprocessen worden geïdentificeerd. Het accent 
ligt niet op het geven van een gedragscode maar op het bevorderen van bewustwording op het punt van kansen en mogelijke problemen. Voorwaarden voor een effectieve vervlechting en ontvlechting kunnen misschien worden geformuleerd.

10 Beleid kan vorm worden gegeven vanuit een hiërarchisch, transactie- of netwerk perspectief. Hoe dan ook, de burger verwacht van de politiek dat op bepaalde momenten knopen worden doorgehakt. Dit handelen wordt primair gestuurd door politieke wil. Wetenschappelijke kennis is op die momenten minder relevant. 


\section{NABESCHOUWING VAN DE EX-POSTANALYSE EN DE CONFERENTIE}

\subsection{INLEIDING}

In deze nabeschouwing worden opmerkelijke reacties op de 'Terugblik op toekomstverkenningen' op een rijtje gezet en verbonden aan de, in die ex-postanalyse geformuleerde, conclusies. Dit is gedaan om het eerste leerdoel te vervullen dat de stuurgroep heeft geformuleerd voor de gedachtewisseling van de conferentie van 24 maart: 'De leerervaringen met nieuwe methoden van toekomstonderzoek voor te leggen aan, en te verifiëren bij, betrokkenen.', zodat de ervaringen en opgedane kennis van dit project kunnen Tanden' bij degenen die zich met toekomstverkenningen en omgevingsbeleid bezig houden. Op deze manier voorziet de stuurgroep zich ook van een reflectie-instrument voor haar eigen leerproces, en kan 'zij leren van de ervaringen van de makers en de gebruikers van de toekomstverkenningen'. (Dit is het tweede leerdoel voor de conferentie.). Op basis van de ervaringen kunnen ook verbeteringen geformuleerd worden en het derde leerdoel van de conferentie was: 'te verkennen welke verbeteringen er gewenst zijn in de interactie tussen verkenningstrajecten en beleidsprocessen.'

Eerst wordt geverifieerd of de deelnemers aan de conferentie zich konden vinden in het gehanteerde conceptuele kader. Bovendien is er bij het eerste leerdoel ruimte voor kritische noten over het discussiestuk 'Terugblik op toekomstverkenningen'. Om deze opmerkingen zinvol weer te geven, maken we gebruik van de conclusies, die in de 'Terugblik op toekomstverkenningen' naar voren kwamen. Per conclusie worden ook de leerpunten en -ervaringen weergegeven, die door deelnemers van de conferentie werden benadrukt of aangedragen. Op sommige conclusies is minder reactie gekomen, dan op andere.

In het laatste deel van de nabeschouwing zijn de meer algemene opmerkingen over de 'Terugblik op toekomstverkenningen' en het onderwerp van discussie weergegeven. Bovendien geeft de stuurgroep aan op basis van welke conclusies zij de volgende fase van het project $T \& \circ$ in zal gaan.

\subsection{REACTIES EN LEERPUNTEN EN -ERVARINGEN PER CONCLUSIE UIT DE 'TERUGBLIK OP TOEKOMSTVERKENNINGEN'}

1 Uit de Terugblik op toekomstverkenningen' bleek dat het verkennen van de toekomst populair is. Vrijwel elke zich respecterende organisatie of eenheid lijkt bezig met een, voor de eigen organisatie relevante, toekomstverkenning. Opvallend is dat elke verkenning zijn couleur locale heeft. De indruk bestaat dat daarmee ook een aanzienlijk deel van de sectorale beleidsovertuigingen wordt meegenomen. Daarmee wordt niet ontkend dat verkenningen worden ingezet om het 'willen' in de samenleving te achterhalen. Er is wel een be- 
wustzijn dat verkenningen breder getrokken moeten worden. Bij aanvang wordt dit ook vaak uitgesproken. Gedurende het proces wordt de ambitie meestal teruggeschroefd.

\section{Reacties}

Uit de werkgroepdiscussies blijkt vooral dat de beleidsopvattingen van de eigen sector gehandhaafd blijven als niet met relevante actoren binnen die sector discussies worden aangegaan, of als niet wordt geïnventariseerd wat de problemen, oplossingen en wensen volgens hen zijn. Het betrekken van personen en organisaties uit de eigen beleidssector vergt al veel inspanningen. Er is in de werkgroepdiscussies minder uitgebreid gesproken over de andere beleidssectoren die betrokken zouden kunnen worden.

Tijdens de conferentie werd de couleur locale van verkenningen bevestigd en ook dat de meeste verkenningen wel de intentie hadden om buiten de eigen beleidssector te kijken bij het opstellen van de toekomststudie. In de meeste gevallen is dit alleen gelukt door informatie uit andere toekomststudies te betrekken, bijvoorbeeld de CPB scenario's op het gebied van economische ontwikkelingen. Maar veelal werd de actieve betrokkenheid, zeker van personen en organisaties uit andere beleidssectoren, in de loop van het proces minder. Vaak was daarvoor meer dan één oorzaak aan te wijzen: bijvoorbeeld de actualiteit die alle aandacht gaat opeisen (zoals het uitbreken van de varkenspest), preoccupatie met de eigen beleidssector gecombineerd met weinig tijd (werkgroepdiscussies Landbouwscenario's Brabant en Woonverkenningen), of zelfs een soort stammenstrijd (werkgroepdiscussies Woonverkenningen en NL 2030), of, bijvoorbeeld, een slechte interne communicatie.

\section{Leerpunten en -ervaringen}

In een werkgroepdiscussie is aangegeven dat er wel geïnvesteerd moet worden in de interdepartementale betrokkenheid ${ }^{1}$ en, met name, de (intersectorale) betrokkenheid binnen de eigen organisatie. Het top- en middenmanagement lijkt daarbij een belangrijke rol te spelen. Er is gezegd dat: "het geen zin heeft een toekomstverkenning te starten zonder de belangstelling van een bepaalde aanpak van die toekomststudie." 2

Ook is een aanbeveling geweest om externe informatie te gebruiken, bijvoorbeeld de CPB scenario's. Daarbij is opgemerkt dat dit wellicht alleen bij scenariostudies moet gebeuren, die over het 'willen' gaan. ${ }^{3}$ In de discussies over de Natuurverkenning is de aanbeveling gedaan om meer rekening te houden met de regie en timing van de verschillende verkenningen.

2 In de Terugblik op toekomstverkenningen' bleek dat strikt wetenschappelijk gefundeerde verkenningen in de klassieke traditie ('ontdek de feiten') in de huidige toekomstverkenningen niet meer toegepast worden. Vaak gaat het om een combinatie van mogelijke, waarschijnlijke en wenselijke toekomst- 
beelden. Soms is er sprake van een tamelijk ondoordachte menging van kennis over trends, denkbare ontwikkelingen en wensbeelden.

\section{Reacties}

Tijdens de conferentie bleek dat inderdaad verwarring ontstond uit de menging van de soorten informatie in de verkenningen (werkgroepdiscussies Questa, NL 2030). Onduidelijk werd wat de toekomstbeelden waren en waartoe zij dienden. Uit de discussies tijdens de conferentie bleek ook dat de meeste mensen niet geloven in een scheiding van de drie soorten kennis over de toekomst, maar wel in een onderscheid tussen deze drie. ${ }^{4}$

\section{Leepunten en -ervaringen}

Een leerpunt was om 'willen', 'weten' en 'kunnen' zoveel mogelijk te onderscheiden. De drie arena's: politiek, beleid en onderzoek, zouden wel hun eigen verantwoordelijkheden en rationaliteit zoveel mogelijk moeten nastreven (werkgroepen Questa en Woonverkenningen). Aan het begin van ieder verkenningentraject zou over de mate van vervlechting en ontvlechting van de drie nagedacht moeten worden (werkgroep NL 2030). Ook werd het ontwerpend onderzoek aanbevolen. Daar zouden misschien kansen liggen om de soorten kennis met elkaar te confronteren. Ook zou het 'doen' aan dit rijtje toegevoegd kunnen worden. Frieling: 'Aan het 'willen', 'weten' en kunnen', zou ik het 'doen' willen toevoegen." 5

Het niemandsland tussen de onderzoeks- en beleidsarena's (ook een naadloos web genoemd door Van Assen in de NVK), zou met specialisten opgevuld kunnen worden. Van Latesteijn zei hierover tijdens de plenaire discussie: "In de discussie over Questa bleek dat het niemandsland in de vervlechting tussen willen, weten kunnen' juist gevuld moest worden door professionals, die misschien tussen onderzoekers en beleidsmakers in zitten." 6

Ook werd opgemerkt dat misschien op sommige momenten 'willen', 'weten' en 'kunnen,' juist vervlochten zouden moeten worden (met name aan het begin van het proces ${ }^{7}$ en op andere momenten juist meer ontvlochten.

Een meer algemeen leerpunt voor het vervolgtraject was bij deze conclusie, dat (meer) onderzoek gedaan kan worden naar de condities waaronder 'willen, weten en kunnen' vervlochten en ontvlochten zouden moeten worden.

Ook zou er misschien meer de nadruk op het 'willen' moeten liggen in de scenario's, het zouden meer politieke scenario's moeten zijn (werkgroepdiscussies Woonverkenningen, NL 2030, NVK). Onder andere Wiersinga merkt op: “Het is jammer dat de verkenningen een technische exercitie worden en de normatieve verkenningen verdwijnen. Deze laatste zouden juist politiek gebruikt kunnen worden." 8

3 In de Terugblik op toekomstverkenningen' blijkt dat het opdrachtgeverschap van de verkenningen nauwelijks eenduidig is te omschrijven. Bij de rijks- 
overheid bestaan er lagen van opdrachtgevers, waardoor de communicatielijnen lang worden en verschillende interpretaties van de opdracht ontstaan. Er is regelmatig sprake van een gemengde opdrachtgevers- en opdrachtnemersrol.

\section{Reacties}

Tijdens de conferentie bleek een (organisatorisch) gemengde opdrachtgevers/ -nemers rol meestal niet als problematisch ervaren te zijn, soms juist als een voordeel (werkgroepdiscussie Woonverkenningen).Een gemengde rol van, met name, politici en beleidsmakers leverde wel problemen. Vaak was dat in een later stadium van het onderzoek, bijvoorbeeld bij de overdracht van opgedane kennis naar andere beleidsonderdelen (werkgroepdiscussies Questa, Landbouwscenario's).

\section{Leerpunten en ervaringen}

In de fase waarin de opdracht geformuleerd wordt zou er veel interactie tussen de opdrachtgever en -nemer moeten zijn. Een aantal deelnemers aan de conferentie vond dat er een grotere rol weggelegd is voor politici in de opdrachtformulering (werkgroepdiscussies NL 2030, Woonverkenningen, Questa). Ook een aanbeveling is om in de voorbereidingsfase veel aandacht te besteden aan de rol die de politiek in de loop van het verkenningentraject moet spelen. Mw. Booi: "Politiek moet aan het begin een rol gegeven worden. Iedere keer moet weer bepaald worden hoe die rol ingevuld moet worden." 9

In de werkgroepdiscussie over Brabant werd opgemerkt dat 'het formuleren van duidelijke doelstellingen een aandachtspunt is'. ${ }^{10}$

In de werkgroep van de NVK werd opgemerkt dat het verschil maakt of de opdrachtgever een netwerkbenadering accepteert, of niet. Als er geen interactie gewenst is, dan moet het onderzoek ook niet de interactie opzoeken.

In een aantal werkgroepdiscussies werd opgemerkt dat de opdrachtgever veel vertrouwen moet hebben in de opdrachtnemer, en ook andersom. Dat zou ten goede komen aan de inhoud van het onderzoek (Woonverkenningen, Plenair, Brabant). Bijvoorbeeld in de Woonverkenningen en in Brabant 2050 is veel vrijheid gegeven. Dat is de uitkomsten van het onderzoek ten goede gekomen.

4 Verkenners zijn eigen beleidsmedewerkers, aangevuld met externe onderzoekers. Zij zijn in staat een reflexieve houding aan ten nemen, en bedenken creatieve aanpakken. Zij trekken onderzoekers aan, om de factfinding te verzorgen en activeren andere beleidsambtenaren en experts om denkbare en wenselijke toekomstbeelden te genereren. Daarbij wordt vrij eclectisch omgegaan met trendstudies en ander 'feitenmateriaal'. 


\section{Reactie}

Tijdens de werkgroepdiscussies bleek dat de taakverdeling en verantwoordelijkheden tussen de actoren en instellingen niet scherp te trekken zijn. Verkenners hebben binnen een ministerie inderdaad een reflectieve en creatieve rol. Maar zij zitten in een spanningsveld tussen een beleidsfunctie en een planbureaufunctie (respectievelijk handhaving en uitvoering van huidig beleid versus beleidsvernieuwing). Dit kwam in alle werkgroepdiscussies ter sprake. Onder andere in de NVK werd door Van Assen opgemerkt dat ondanks een "keurig geregisseerde ontvlechting van beleidsmakers, verkenners en onderzoekers de grenzen door de actoren inhoudelijk steeds anders gelegd worden. De spanning ontstaat omdat de actoren van elkaar het gevoel hebben dat ze op hun terrein te komen." "1

De eclectische omgang met trendstudies en ander 'feitenmateriaal' is niet uitvoerig besproken in de werkgroepen. Wel is bijvoorbeeld in de werkgroepdiscussie van Questa aan de orde gekomen of de studies die gebruikt worden, feiten leveren of wenselijkheden bevatten. Zo is Schuring van mening dat: "In de Questa scenario's zijn geen wenselijkheden geslopen. Dit in tegenstelling tot wat in de Terugblik op toekomstverkenningen' staat". Dikmans, deelnemer in dezelfde werkgroep, is van mening dat dit wel is gebeurd, door bijvoorbeeld vast te houden aan de economische randvoorwaarden van het CPB. ${ }^{12}$

Verkenners betrekken niet alleen beleidsambtenaren en experts bij de verkenningen. Juist ook andere maatschappelijke organisaties, individuen, ondernemers enzovoorts worden betrokken (werkgroepdiscussies Brabant, Woonverkenningen, NL 2030 en plenair).

\section{Leerpunten en -ervaringen}

Een aantal keren is opgemerkt dat juist verkenningen en ontwerpend onderzoek de ruimte bieden om factfinding met wensen en mogelijkheden te confronteren (werkgroepdiscussies Questa, NVK en Plenair). Een nieuw soort deskundigen tussen de onderzoeks- en beleidsarena in, zou uitkomst kunnen bieden. Anderen zagen hier geen oplossing is. Het spanningsveld tussen 'wenselijk' en 'mogelijk' wordt met nieuwe deskundigen, volgens hen, niet zomaar opgeheven (werkgroep Questa). Een ander nadeel zou kunnen zijn dat verkenningen nog verder van beleidsmakers af zouden komen te staan. Verroen bijvoorbeeld vindt de verkenningen "uitdrukkelijk een middel voor beleidsmedewerkers" en niet per se voor een nieuwe groep deskundigen. ${ }^{13}$

Aanbeveling is, in ieder geval op dit punt, om de inhoud van het toekomstonderzoek niet los te zien van de doelstellingen (zie verderop, de 'meer algemene opmerkingen')

5 Verkenningen worden vaak 'gewoon gestart'. Soms gaat het om normale procedures waar de verkenners redelijk (denken te) weten wat verwacht wordt, meestal om eenmalige trajecten waar de betrokkenen stap voor stap beslissingen nemen over de volgende stap. In de verkenningstraject zijn met 
regelmaat buig- en knikpunten waar te nemen, waarop de richting van de verkenning verandert. Soms komen de koerswijzigingen voort uit keuzen van de verkenners, maar met regelmaat vinden ook externe interventies plaats met name uit de beleidswereld.

\section{Reacties}

Tijdens de conferentie bleek dat verkenningen vaak wel een aanleiding of een doel hebben (alle casus), maar dat de doelstellingen kunnen verschuiven (werkgroepen Questa, Brabant 2050, NL 2030).

De Woonverkenningen en de NVK hadden wel een duidelijke doelstelling. Zeker in de Woonverkenningen heeft men het proces in een nauwe interactie tussen de opdrachtgever en -nemer vormgegeven, waardoor verschillen in verwachting over de inhoud en de uitkomst nauwelijks ontstonden.

In de werkgroep van NL 2030 werd één buigpunt weerlegd dat in de 'Terugblik op toekomstverkenningen' was opgevoerd. De Jong en Verbaan merken op dat minister De Boer, in tegenstelling tot wat zij in de Terugblik op toekomstverkenningen' beweert, geen vierde streefbeeld met daarin het huidige beleid, heeft geintroduceerd. Volgens hen waren er van het begin af aan al vier perspectieven.

In de meeste casus waren er inderdaad knik- en buigpunten, maar tijdens de conferentie bleek dat deze veelal niet als problematisch werden ervaren. In de discussie over NL 2030 merkt Van der Werf bijvoorbeeld op: “Om te voorkomen dat uit de scenario's werd gekozen, had misschien een fase ingelast kunnen worden waarin werd gekeken wat de uitgangspunten waren in de scenario's. Maar het is belangrijker hoe met de conclusies uit de discussies is omgegaan." 14 Over de politieke interventies wordt in de werkgroepdiscussie over de Woonverkenningen gezegd door Schuyt: "Politieke interventies zijn onontkoombaar en moeten daarom georganiseerd worden." 15

\section{Leerpunten en -ervaringen}

Tijdens de discussies bleek dat het moeilijk is om met interventies rekening te houden. In de werkgroepdiscussie van NL 2030 werd opgemerkt dat een organisatie zich in haar houding tegenover veranderingen kan voorbereiden op interventies. Opgemerkt is ook dat "Verkenningen moeten aanshiten bij interdepartementale kabinetsbrede discussies." ${ }^{16}$ Er kan met mogelijke ministerwisselingen rekening gehouden worden (De Jong, NL 2030). In dezelfde werkgroepdiscussie werd een aantal malen opgemerkt dat in een eerder stadium betrekken van de politiek verantwoordelijke misschien interventies kan voorkomen.

Bij de NVK werd door Lammers opgemerkt dat "de NVK een beetje in het luchtledige is gemaakt omdat er geen aansluiting was op het beleidsproces van LNV." $17 \mathrm{De}$ aanbeveling is om die aansluiting wel te organiseren. Een zelfde soort opmerking kwam ook in de discussie over Brabant (met name over de landbouwverkenningen werd dit gezegd). 
6 De overdracht van de verkenningen is over het algemeen niet geregeld. Soms wordt de overdracht vorm gegeven door de overhandiging van éen of meer rapporten en wachten te verkenners verder af, of zij beginnen aan een nieuwe opdracht. Bij verkenningen waar de ambitie verder reikt dan het vaststellen van de feiten blijkt het moeilijk om dat wat geleerd is in verkenningen over te dragen aan degenen die, in een organisatie en van de opdrachtgevers, niet nauw betrokken waren bij het verkenningenproces. Meestal neemt de opdrachtgever daarvoor ook geen, of weinig tijd, en heeft de opdrachtnemer weinig tijd ingeruimd om hier nog aan te werken.

\section{Reacties}

Over het algemeen is men het er mee eens in de werkgroepdiscussies en plenair dat te weinig aandacht besteed wordt aan de overdracht, vaak wordt er te weinig tijd voor genomen (werkgroepen Brabant, Questa). Maar er vinden ook onverwachte kennisoverdrachten plaats (NVK, NL 2030). Tjallingii: "Ik vond de relatie tussen ICES en NL 2030 juist interessant omdat voor ICES is gekeken welke brug investeerders in de toekomst nodig hebben." 18

\section{Leerpunten en -ervaringen}

De overdracht zou misschien verbeterd kunnen worden door het 'doen' in een vorm van agendapunten toe te voegen aan het onderzoek. Door Frieling werd ook aanbevolen om ambtenaren te verplichten alle stukken (nogmaals) te lezen (werkgroepdiscussie NL 2030 en Plenair).

Ook werd aanbevolen om de formulering van beleidskeuzen het doel te laten zijn van verkenningen, zodat de politiek kan kiezen (Rutjens, plenair).

7 Vooral verkenners leren van hun verkenningen. Als deze personen vervolgens niet behouden blijven voor de organisatie en voor vervolgtrajecten, valt de benutting van kennis tegen. Wanneer de bestuurlijke opdrachtgever sterk betrokken is geweest bij de verkenning en een rol blijft spelen in vervolgtrajecten, dan kan een aanzienlijk deel van de kennis worden bewaard, benut en verrijkt.

\section{Reacties}

In een aantal werkgroepdiscussies (Woonverkenningen, NL 2030, Questa, Brabant) werd opgemerkt dat het beeld dat over de overdracht van kennis uit de verkenningen in de 'Terugblik op toekomstverkenningen' is geschetst te negatief was. $\mathrm{Er}$ is meer met de verkenningen gedaan dan blijkt. Veelal heeft dit te maken met de beperking van het onderzoeksobject, die in de 'Terugblik op toekomstverkenningen' is aangebracht. De Jong (werkgroep NL 2030): “Het ministerie van VROM heeft een geheugen als een olifant. Hij vindt dat er meer terecht is gekomen van de verkenningen dan uit dit stuk blijkt." 19

De invloed en het effect van de verkenningen en de debatten die erover gevoerd zijn gaan verder dan de traditionele beleidscyclus. Bijvoorbeeld, beelden en ideeën 
komen terug in nieuwe discussieronden, bijvoorbeeld voor de Vijfde nota. Het is moeilijk meetbaar wat precies de invloed is geweest, bijvoorbeeld, bij maatschappelijke organisaties (werkgroepen Woonverkenningen, NL 2030).

\section{Leepunten en -ervaringen}

Een wens van veel deelnemers is, om meer naar de inhoudelijke effectiviteit van de toekomstonderzoeken te kijken (zie hieronder).

\subsection{MEER ALGEMENE OPMERKINGEN OVER DE 'TERUGBLIK OP TOEKOMSTVERKENNINGEN'}

In de discussies tijdens de conferentie bleek dat over het algemeen de weergave van de interactie tussen beleidsmakers en onderzoekers in de Terugblik op toekomstverkenningen' waardevol werd geacht. Ook het, in de ex-postanalyse gehanteerde, conceptueel kader werd waardevol gevonden. Den Dunnen vindt bijvoorbeeld: "Het analysekader met een onderscheidt tussen willen, weten en kunnen is erg vruchtbaar. Ik stel voor om dit op de agenda te zetten van ieder verkenningentraject." 20

Onder andere uit de Stuurgroepvergadering waarin de conferentie geëvalueerd is, bleek dat wel verduidelijkt moeten worden wat ontvlochten of vervlochten moet worden: de instellingen, de verschillende soorten kennis (willen, weten en kunnen), de beleidsfunctie en de planbureaufunctie etc. ${ }^{21}$

Het meeste commentaar richtte zich op de strakke afbakening van het onderzoeksonderwerp van de 'Terugblik op toekomstverkenningen' en het uitgangspunt van een netwerkbenadering. Bijvoorbeeld in de discussie over de Woonverkenningen, de NVK ‘97 en Nederland 2030, werden hier opmerkingen over gemaakt.

Bijvoorbeeld Koffijberg, nauw betrokken bij de Woonverkenningen: "Ik mis in de Terugblik' dat, nadat de woonverkenningen gepubliceerd zijn, de politiek het stuk heeft overgenomen en er nog een maatschappelijk debat is georganiseerd."

Bij de Natuurverkenningen ' 97 werd gesproken over de beperking van de aanname van een beschrijving in termen van een netwerkbenadering, omdat die niet overal de reële situatie weergeeft. In deze werkgroepdiscussie werd, bijvoorbeeld, meerdere malen opgemerkt dat het ministerie van LNV, relatief gezien, erg topdown wil sturen. Ook in de volgende Natuurverkenning zal daar rekening mee gehouden moeten worden. Lammers: “De opdrachtgever hanteerde geen netwerkbenadering." En iets verder in de discussie merkt hij op dat: "er een premisse is van de netwerkbenadering in de Terugblik'. Daarin zit wel een interessante mix van willen, weten en kunnen, maar het roept ook de vraag op waarom politici en beleidsmakers met het willen van actoren rekening zouden willen houden." 22 
Een belangrijke kritische noot die uit meer dan één hoek kwam, was dat, om de effectiviteit van verkenningen vast te kunnen stellen, het noodzakelijk is om uit te gaan van het doel van de individuele verkenning. Bijvoorbeeld Van de Klundert merkt op: "De vraag hoe kan de effectiviteit van gebruik van verkenningen in beleid vergroot worden', is niet beantwoord'. Als er wel antwoord op gezocht wordt, dan moet het doel van de opdrachtgever het uitgangspunt zijn." 23 Ook de inhoud van de verkenningen, de doelen van de opdrachtgevers, en bijvoorbeeld de ambtelijke context zijn daarbij waardevol. In de 'Terugblik op toekomstverkenningen' is bijna alleen naar de interacties tussen actoren gekeken. Dit riep tijdens de conferentie de behoefte op om meer naar de inhoud te gaan kijken.

De effectiviteit van een toekomstverkenningen is niet alleen afhankelijk van de mate van de vervlechting of ontvlechting van de twee arena's, hun soorten kennis of instellingen, maar ook van de condities waaronder de vervlechting of ontvlechting plaatsvindt. Hierbij zijn het doel van het toekomstonderzoek en het soort lange termijn informatie dat het onderzoek oplevert onontbeerlijke variabelen in een effectiviteitanalyse, evenals de doelen en spelregels van de politieke (besluitvormings)arena. 


\section{NOTEN}

1 Werkgroepdiscussie NL 2030, conferentie 24 maart 2000

2 Werkgroepdiscussie Questa, conferentie 24 maart 2000

3 idem

$4 \quad$ Plenaire discussie, werkgroepdiscussie NVK, Questa en NL 2030, conferentie 24 maart 2000.

5 Plenaire discussie en Werkgroepdiscussie NL 2030, conferentie 24 maart 2000

6 Plenaire discussie, conferentie 24 maart 2000

7 Werkgroepdiscussie Woonverkenningen en NL 2030, conferentie 24 maart 2000

8 Werkgroepdiscussie NVK, conferentie 24 maart 2000

9 Werkgroepdiscussie Woonverkenningen, conferentie 24 maart 2000

10 Werkgroepdiscussie Brabant, conferentie 24 maart 2000

1 Werkgroepdiscussie NVK, conferentie 24 maart 2000

12 Werkgroepdiscussie Questa, conferentie 24 maart 2000

13 Idem

14 Werkgroepdiscussie NL 2030, conferentie 24 maart 2000

15 Werkgroepdiscussie Woonverkenningen, conferentie 24 maart 2000

16 Werkgroepdiscussie NVK, conferentie 24 maart 2000

17 Idem

18 Werkgroepdiscussie NL 2030, conferentie 24 maart 2000

19 Idem

20 Idem

21 Verslag stuurgroepvergadering T\&O, 19 april 2000

22 Werkgroepdiscussie NVK, conferentie 24 maart 2000

23 Idem 


\section{BIJLAGEN}


- $\quad$ september 1999, Ministerie van Verkeer en Waterstaat (V\&w), RLD, Den Haag

- september 1999, Ministerie van Volkshuisvesting Ruimtelijke Ordening en Milieu (VROM), Den Haag

- Dubbelinterview 7 september 1999, Ministerie van VROM, Den Haag

- september 1999, SC-DLO, Wageningen

- 13 september 1999, Looiersgracht, Amsterdam

- 14 september 1999, LEI-DLO, Den Haag

- 16 september 1999, De Stad B.V., Amsterdam

- 16 september 1999, Provinciehuis Noord Brabant, Den Bosch

- 20 september 1999, Centraal Station, Utrecht

- Dubbelinterview 22 september 1999, Adviesdienst Verkeer en Vervoer, Rotterdam

- 28 september 1999, Ministerie van Landbouw, Natuurbeheer en Visserij (LNV), Den Haag

- 30 september 1999, Provinciehuis Noord Brabant, Den Bosch

- 14 oktober 1999, Ministerie v\&w, DGG, Den Haag

- 19 oktober 1999, Ministerie v\&w, Den Haag

- 19 oktober 1999, Ministerie VROM, RPD, Den Haag

- 21 december 2000, Nationaal Woninginstituut, De Bilt

- 21 december 2000, DRo gemeente Amsterdam, Amsterdam

- 17 januari 2000, Provinciehuis Noord Brabant, Den Bosch

- 20 januari 2000, Tweede Kamer, Den Haag 
B.1 INLEIDING

De ex-postanalyse richt zich op zes verkenningstrajecten die eind jaren ' 90 hebben plaats gevonden. Al deze trajecten zijn ingezet om een bijdrage te leveren aan strategisch (omgevings)beleid van een of meer overheden. Per casus is een reconstructie uitgevoerd. Daarbij is aandacht besteed aan de aanleiding tot de verkenning, de invulling van opdrachtgever- en opdrachtnemerschap, het verloop van het verkenningstraject, de overdrachtsregeling met beleidsmakers en het gebruik van de verkenning. Tevens zijn de verkenningen beoordeeld in het licht van de gehanteerde sturingsmodellen door beleidsmakers en verkenners. In de vergelijking van de zes casusstudies is het verkenningsproces als geheel beoordeeld in het licht van het netwerkmodel.

\section{B.2 CASUS 1 EN 2: SCENARIO'S VOOR LANDBOUW EN RUIMTEGEBRUIK EN BRABANT 2050}

\section{Scenario's voor landbouw en ruimtegebruik}

De oriëntatie op interactie met actoren uit de agrarische sector is een belangrijke karakteristiek van deze verkenning op Provinciaal niveau. Aanleiding voor deze scenariobouw was de heftige kritiek die op het afgeronde provinciale streekplan werd gegeven. Boeren stonden met tractoren op de stoep van het Provinciehuis om hun ongenoegen te uiten. Dit was aanleiding voor het Provinciaal bestuur en, met name, één gedeputeerde om de verkenners veel ruimte te geven om mogelijke toekomstige ontwikkelingen, die van invloed zouden zijn op de agri-business in Brabant, te onderzoeken. De idee daarbij was dat met actoren uit de beleidssector samen vastgesteld moest worden, wat mogelijke toekomstige ontwikkelingen zouden zijn. Trendanalyses stonden daarbij in dienst van het formuleren van de belangrijkste onzekerheden en mogelijke ontwikkelingen. Aan de hand van twee scenario's (Onze hof en Brabant Globaal) werd over mogelijke ontwikkelingen gepraat en moest voorkomen worden dat actoren in oude tegenstellingen over de wenselijkheid van een toekomst zouden gaan praten. Op basis van de analyse van deze casus ontstaat de indruk dat het wederzijdse begrip tussen actoren en het begrip voor de situatie waarin de Brabantse boeren zich bevinden is toegenomen dankzij de verkenning.

Het belangrijkste kritiekpunt bij deze verkenning is de moeizame verbinding ervan met de dagelijkse beleidspraktijk van provinciale staten en de ambtelijke diensten. De interne agenda en logica van deze organen en organisaties maakte het moeilijk om de aandacht voor de verkenning vast te houden. Niet helemaal duidelijk is of dit te voorkomen was geweest. Het gaat hier om de vraag hoe groot de span of attention kan zijn bij diverse partijen. We nemen in ieder geval in deze casus waar dat de verkenning op afstand van de Provincie wordt gezet, waardoor de overdracht aan de eigen organisatie bemoeilijkt wordt. 
De twee mogelijke toekomstbeelden in Onze Hof en Brabant Globaal zijn door het Provinciebestuur kritisch bekeken op hun haalbaarheid en voor diverse gebieden in Brabant. De beelden zijn ook bekeken in termen van hun onontkoombaarheid. Deze aanpak leidt in potentie tot beleidsdifferentiatie en beleidsinnovatie (mede ook door de combinatie van sectorbeleid en gebiedsgericht beleid)

\section{Brabant 2050}

In de eerste fase van dit project was het belangrijkste product Het Brabant Manifest. Daarin werden denkbare toekomstbeelden verkend. Het Manifest moest de vorming van toekomstvisies stimuleren, zowel binnen als buiten het provinciale apparaat. Bijzonder aan deze verkenning is de activering van spraakmakende mensen aan het begin van het proces. Hun inbreng is in aanzienlijke mate agendavormend geweest. Hoewel dit wel tot enige kritiek heeft geleid in de media en bij sommige organisaties, had de aanpak als voordeel dat met name ook de denkbare, maar niet direct voor de hand liggende, toekomsten in beeld kwamen. De verrassingsgraad werd met andere woorden daardoor verhoogd. Dit gaat hand in hand met een verhoogd politiek risico. Burgers en media zouden immers de vraag kunnen stellen of de beelden nu wel of geen Provinciaal beleid zijn. Bij het Manifest heeft de opdrachtgever eerst de reacties afgewacht aleer verder te gaan met het verkenningstraject. In de tweede fase, nadat het Manifest reacties had opgeroepen, is het projectbureau van de Provincie de discussie in de Brabantse samenleving meer gaan stimuleren en faciliteren.

Het proces van Brabant 2050 is op de tast vorm gegeven, waarbij de opdrachtgever en -nemer in interactie steeds hun vervolgstappen vaststelden. De lijnen binnen het Provincieapparaat zijn daarvoor ook kort genoeg. Onder andere door deze platte structuur was het mogelijk om de verkenning te koppelen aan concrete projecten. Uit het gesprek met Van Geel bleek dat deze werkwijze ook een gevolg was van de toekomstverkenning in het Manifest en van de tijdgeest. Mede door de gelijktijdige ontwikkeling van toekomstbeelden in meer generieke zin en door de concrete projecten die behulpzaam zouden kunnen zijn om invulling te geven aan de wenselijke elementen van deze beelden, heeft de verkenning aan beleidsrelevantie gewonnen. In deze verkenning heeft men tot op heden vooral vernieuwende projecten bedacht bij diverse toekomstbeelden die in samenhang en over de grenzen van provinciale organisatieonderdelen heen vorm hebben gekregen. Of deze ook in beleidsnota's terug te vinden zullen zijn, is vooralsnog onduidelijk. In de provinciale toekomstverkenningen stuit men met regelmaat op organisatorische verkokering en domeinbewaking.

\section{B.3. CASUS 3: NATUURVERKENHING 97}

De opdracht voor de Natuurverkenning 1997 (NVK 97) is door het ministerie van Landbouw Natuurbeheer en Visserij (LNV), directie Natuurbeheer, verstrekt aan de Coördinatiegroep Uitvoerende Instellingen. De NVK 97 zou een eerste gezamenlijk 
product worden van onderzoeksinstellingen die een Natuur Planbureau functie (NPB - $f$ ) hadden.

De Natuurverkenning is, van de onderzochte casus, de meest klassieke in de zin van scheiding tussen willen en weten. Kenmerkend voor deze verkenning was, dat er een gedegen wetenschappelijk product geleverd moest worden. De verkenning diende feiten vast te stellen over ontwikkelingen in het recente verleden en over de effectiviteit van beleid. Het beleid zelf mocht niet ter discussie staan en er moest geen beleidsinnovatie op gang gebracht worden. Hooguit kon worden geconstateerd of bepaalde beleidsinstrumenten wel voldoende uit de verf kwamen of bijgestuurd moesten worden. De Natuurverkenning heeft geleid tot een wetenschappelijk rapport met kennis over de huidige stand van zaken en een voorzichtige verkenning van mogelijke ontwikkelingen.

Zoals bij klassiek toekomstonderzoek vaker het geval is, wordt de relatie tussen beleid en onderzoek niet uitgebreid geproblematiseerd. Het zijn min of meer eigen werelden en met behulp van een opdracht gaat er soms iets van de beleidswereld naar de verkenningswereld en met behulp van een schriftelijke document stelt de verkenningswereld inzichten in feiten beschikbaar. Tijdens het proces van verkennen hebben de verhoudingen tussen de onderzoeksinstellingen en het ministerie wel ter discussie gestaan, met name bij het ministerie. Zij waren van mening dat het onderzoek meer beleidsgericht moest worden uitgevoerd. Zij hebben in de opdrachtformulering een duidelijke rol gespeeld, vooral in het verkennende deel. In meer tactische zin is de verkenning wel (wellicht onbedoeld) gebruikt voor interactie, maar dan met name die tussen de kennis aanleverende instituten die een planbureaufunctie voor het ministerie van LNV moesten gaan vervullen. In dat licht is de verkenning dus ook te beschouwen als een instrument voor de eigen organisatie. Maar procesontwerpen, overdrachtregelingen en interactie zijn daarbij niet de geëigende termen geweest.

De onderzoekers, die de feiten vast wilden stellen, waren niet de mening toegedaan dat deze feiten veranderden wanneer de gedachten bij beleidsmakers over de benutting van het onderzoek veranderden. Onderzoekers die de feiten willen vast leggen, achten het meestal ook niet hun taak om het beleid te vernieuwen. Mochten ze die gedachte toch ontwikkelen, dan krijgen ze van beleidsmakers al snel te horen zich daarmee niet te bemoeien. De twee domeinen overlappen nauwelijks, lijkt het.

In het verkennende deel van de Natuurverkenning bleek echter dat deze verhoudingen wel een spanning opriepen. Daarbij kon het domein van de beleidsmakers het zich veroorloven om meer inhoudelijk van zich te laten horen. De scheiding tussen feiten en wensen was daar minder duidelijk te trekken. Omdat dit slechts een klein deel van de NVK 97 omvatte en er voor werd gekozen door de opdrachtgever en -nemers om in het verkennende deel voorzichtig te opereren, is de scheiding tussen de twee domeinen in tact gebleven. Mede hierdoor is de impact 
van de NVR 97 vooral via de opvallende 'feiten' verlopen in de verkenningen die beleidsmakers kunnen benutten in de agendering van thema's.

\section{B.4 CASUS 4: NEDERLAND 2030}

Het verkenningstraject Nederland 2030 heeft onmiskenbaar invloed gehad op beleidsprocessen. Nog steeds wordt gesproken over het scenario stedenland en over benutting van kennis uit het scenario stromenland. De start van de verkenning kan worden gevonden in uitspraken van de toenmalige minister van VROM. Anderzijds kan ook worden gezegd dat de verkenning een 'normaal' onderdeel vormt van het cyclische proces van nationale plannenmakerij op het nationale niveau. "Het was gewoon weer eens tijd voor een verkenning", zei één van de geïnterviewden.

In het eerste deel van Nederland 2030 is expliciete aandacht besteed aan het proces van verkennen als zodanig. Daarna ging het overwegend 'werkender weg'. Typerend voor deze verkenning was dat er, ondanks het expliciete procesontwerp, interventies zijn gepleegd. Dit gebeurde omdat in de lopende beleids- en politieke debatten nieuwe eisen gesteld werden aan de verkenning. Er lag bijvoorbeeld een prangende vraag van met name de Tweede Kamer aan de minister om een politieke visie. Door hier gehoor aan te geven is de ruimte om beleidsvrij te verkennen verkleind. Ook werd gedurende de eerste ronde van de verkenning duidelijk dat de ambitie van de minister om een geïntegreerde nota voor ruimte en milieu politiek niet haalbaar is. Nederland 2030 is vooral een product van de RPD geworden en vooral in de ruimtelijke ordeningswereld besproken. De inperking (tot uitsluitend ruimtelijke ordening) en buiging in het proces (naar wensbeelden die al lang bestonden in de betreffende beleidswereld) heeft zijn definitieve vorm gekregen door de keuze van de minister voor Stedenland. Daarmee verdween de ruimte om toekomsten te verkennen die niet in dit wensbeeld zouden passen. Een belangrijke kritische meerwaarde van de verkenning, die uitdrukkelijk wel werd nagestreefd door de verkenners bleef hierdoor onbenut: dat was het stellen van de vraag wat de rijksoverheid zou moeten doen in geval er ontwikkelingen optreden die van dat wensbeeld afwijken. Door de uitspraak van de minister zijn de verkenners ook niet meer toegekomen aan de vraag welk beleid ontworpen kan worden indien de samenleving zich toch blijkt te ontwikkelen conform palet, parklandschap of stromenland.

Verder blijkt de overdracht van kennis en leerervaringen met name via personen te verlopen. En op dat punt doet zich een opvallend fenomeen voor, dat we ook in andere casus kunnen waarnemen, namelijk dat de meeste direct betrokkenen bij de verkenning Nederland 2030, na afronding van dit traject, niet meer een centrale rol spelen in de totstandkoming van de vijfde nota. Bij Nederland 2030 is de komst van de nieuwe minister daarbij cruciaal maar ook het vertrekken van de 
betreffende ambtenaren naar andere posities. Mede daardoor is er in het traject van de vijfde nota veel nieuw onderzoek verricht.

\section{B.5 CASUS 5: WOONVERKENNINGEN MMXXX}

Net als bij de Brabantse scenario's voor landbouw en ruimtegebruik is ook bij de Woonverkenningen een belangrijke rol weggelegd voor de sector. Het lijkt erop dat de interactie in Brabant vooral benut is om de vervreemding tussen overheid en sector te verminderen. Bij de woonverkenningen is de interactie vooral opgezet om een ingezet veranderingstraject van het ministerie verder te bestendigen, en dat ook voor alle medewerkers van DGVH te bevestigen. Bovendien werden op deze manier de wensen van de sector verzameld, die daardoor mede bepalend konden zijn voor het 'kunnen van het ministerie. Om het proces goed te laten verlopen zagen zowel opdrachtgever als opdrachtnemer in het verkenningentraject voor het ministerie een rol als regisseur en procesontwerper weggelegd, waarbij veel ruimte aan de verkenners moest worden gegeven.

In tegenstelling tot Nederland 2030 is er bij de Woonverkenningen geen sprake van spanning tussen de politieke opdrachtgever en de opdrachtnemers. De mening overheerst dat dit komt doordat de Woonverkenningen dieper in de organisatie waren weggezet, waardoor de bewindspersoon niet uitgelokt werd door de Kamer of media om een standpunt in te nemen. Een andere verklaring zou kunnen zijn dat de Woonverkenningen meer beleidsconform waren en vooral gingen over de vraag naar nieuwe uitdagingen voor het beleid: hoeveel wonen en wat voor wonen? Dit is op zich wel een boeiende paradox. In het bouwprogramma wordt de woonbehoefte als uitgangspunt genomen, in de ruimtelijke ordening is het juist zo dat de ruimtebehoefte een gevaar is voor de ruimte en dat die zoveel mogelijk in toom gehouden moet worden, en het liefst geconcentreerd moet worden in steden. Of anders gezegd, het volkshuisvestingsbeleid is vanuit de traditie meer geneigd het haalbare als leidraad te nemen, en het ruimtelijke ordeningsbeleid tamboereert sterk op het primaat van de collectieve waarden van open ruimte boven de individuele behoefte aan meer ruimteconsumptie.

Een aanleiding voor deze toekomstverkenning was 'de verschillende probleembelevingen onder de beleidsmakers van het ministerie' ${ }^{1}$ door een groeiende onzekerheid over de ontwikkelingen in de samenleving. Die onzekerheid is voornamelijk ontstaan omdat de dynamiek in de samenleving toeneemt en er een blijvende groei van mobiliteit is. Een van de procesdoelen van Questa was om beleidsmakers van het ministerie te leren omgaan met die onzekerheid. Daartoe zouden zij zelf, samen met het projectteam, mogelijke ontwikkelingen in de 
toekomst bedenken die van invloed zouden kunnen zijn op de mobiliteit, zonder daarbij die ontwikkelingen te beoordelen op wenselijkheid.

De scenario's waren in eerste instantie een methode om de beleidsmedewerkers de wenselijke toekomst (beleidsbehoefte) van de mogelijke te laten onderscheiden. De casus laat vervolgens zien dat de beleidsbehoeften toch gaan domineren in het verkenningstraject. Eerst wordt gedacht in termen van beleidsarme, kwalitatieve toekomstbeelden, waar vervolgens mobiliteitsbeleid voor zou kunnen worden ontwikkeld. Later wordt aan twee behoeften van beleidsmakers tegemoet gekomen. Ten eerste voert de opdrachtnemer kwantitatieve gegevens toe, om daarmee houvast voor beleidsmakers te vergroten (meten is weten). Ten tweede worden beleidsmaatregelen en beleidseffecten ingevoerd. Daarmee verschuift de verkenning niet alleen van mogelijke naar wenselijke toekomsten, de verkenning reproduceert ook steeds meer de opvattingen die leven binnen het departement over het belang van het eigen beleid. Het aantal vrijheidsgraden van de verkenning neemt daarmee af.

Questa was in aanzet dus innovatief van karakter en niet specifiek voor een nieuwe nationale nota bedoeld. De verkenning zou zich moeten richten op mogelijke toekomsten, zelfs als deze kritische vragen zou oproepen aangaande het huidige beleid. Om deze ruimte te scheppen is het project op aanzienlijke afstand van de bestuurlijke en beleidsmatige kern van het ministerie gezet. 'Gaat uw gang opdrachtnemers en wij, opdrachtgevers, zien wel hoe het loopt en zullen naar bevind van zaken handelen', lijkt het credo. Door deze ruimte kwam de overdracht van de opgedane kennis aan het einde van het traject in de problemen.

Questa was tevens bedoeld als een hulpmiddel voor beleidsontwikkeling, maar werd in de praktijk maar in beperkte mate als zodanig gebruikt. Ondanks de tussentijdse aanpassingen op verzoek van beleidsmakers, blijkt Questa niet zodanig te voldoen aan de behoefte van beleidsmakers, dat ze er tijd voor vrij maken in hun agenda. Questa is bijvoorbeeld nauwelijks gebruikt bij het traject van de Perspectievennota dat formeel ingezet was om de gedachtevorming over de beleidsrichting te bevorderen ter voorbereiding van het Nationaal Verkeer en Vervoersplan (NVvP). Het eigen willen (als we het NVvP hier even beschouwen als een departementale wilsbeschikking) lijkt centraal te staan bij het departement. De bereidheid om het eigen 'willen' te toetsen op toekomstvastheid in verschillende mogelijke toekomsten was niet groot. Ook de inbreng van andere actoren in de sector was marginaal.

Bij Questa is wel geëxperimenteerd met combinaties van kwalitatieve en kwantitatieve weergave van toekomstbeelden, en met gebruik van mogelijke toekomsten. Opvallend is dat de mogelijke beelden in de loop van het proces meer gepercipieerd worden als wensbeelden. Een synthese die, zowel in termen van nieuwe methode om de toekomst te verkennen als in termen van beleidsrelevantie aanspreekt, nog niet bereikt is. 


\section{B.7 VERGELUKENDE ANALYSE}

De zes geanalyseerde verkenningen vormen een deelverzameling in een omvangrijke reeks. Een verklaring hiervoor ligt in de dynamiek en complexiteit van de samenleving.

Opvallend is de couleur locale van elke verkenning: de toekomst wordt geschetst in concepten en beelden van de (omgeving van de) beleidssector waarvoor de verkenning wordt gemaakt. De indruk bestaat dat daarmee ook een aanzienlijk deel van de sectorale beleidsovertuigingen wordt meegenomen. Tegelijkertijd worden verkenningen ingezet om het 'willen' in de samenleving te achterhalen.

Bij de aanvang van de meeste verkenningen wordt uitgesproken dat het moet gaan om een interorganisatorisch proces, waarbij de kennis vanuit allerlei gremia wordt benut. Deze ambitie wordt gedurende het proces meestal teruggeschroefd. Deze schijnbare inefficiëntie in de kennisverzameling op het niveau van de verkenningen kan in een beleidsinnovatie of een strategische besluitvorming juist positief uitwerken. Niet alleen omdat andere actoren toegang krijgen tot de besluitvormingsarena maar ook omdat het een grote variatie aan keuzemogelijkheden voor beleid creëert.

\section{De inhoud van hedendaagse toekomstvenkenningen: ingewikkelde mengrormen}

Toekomstverkenningen zijn er deels op gericht om kennis te genereren in de traditionele objectieve zin. Een aanzienlijk deel van de gegenereerde kennis in de verkenningen betreft echter 'mogelijke' en 'wenselijke' toekomstbeelden. De verbeelding speelt daarbij een minstens zo belangrijke rol. Kennis wordt, ons inziens terecht, met deze drie domeinen verbonden. De onderscheiding tussen deze drie kennisdomeinen wordt in onvoldoende mate bewaakt. Nog problematischer is het wanneer denkbare toekomstbeelden na verloop van tijd ineens geïnterpreteerd worden als wensbeelden. Een eigenstandige functie als brengen van kritische boodschappen aangaande de steun voor beleid of de uitvoerbaarheid van beleid of oproep tot nieuw beleid, verdwijnt dan grotendeels naar de achtergrond.

Ten slotte zijn verkenningen vooral gericht op de integratie van kennis tot toekomstbeelden, meer dan op het presenteren van 'de feiten'. Essentieel is dat kennis het combineren van gedachten en feiten tot min of meer samenhangende beelden lijkt te worden.

\section{Het opdrachtgeverschap}

Met name bij de rijksoverheid bestaan er verschillende lagen van opdrachtgevers, waardoor de communicatielijnen lang worden en verschillende interpretaties van de opdracht ontstaan. Dit maakt het moeilijk om tot een adequate, in de toekomst te consolideren, opdrachtformulering te komen.

De opdrachtgevers willen enerzijds dat de verkenning zich verheft boven de dagelijkse beleidspraktijk en tegelijkertijd willen en/of kunnen ze er niet onder uit de 
verkenning te beoordelen in het licht van kansen en bedreigingen voor het dagelijkse beleid. Als men die reflectie toch wil, zet men de opdracht vaak ver weg in de eigen organisatie, of bij een extern instituut met een planbureaufunctie. Die oplossing kan tot gevolg hebben dat de resultaten nauwelijks benut worden. In geen van de onderzochte casus kan aanwijsbaar gesproken worden van een doelbewust proces van gemeenschappelijke wilsvorming, zoals in het ideaaltype van netwerksturing gesteld. Wel wordt in drie verkenningen nadrukkelijk met de sector gecommuniceerd, maar ook daar houden de opdrachtgevers 'hun handen vrij'.

\section{Het opdrachtnemerschap}

Verkenningen worden veelal uitgevoerd door enthousiaste medewerkers van een organisatie -soms aangevuld met externe verkenners/onderzoekers. Zij trekken onderzoekers aan om de fact finding te verzorgen en activeren andere beleidsambtenaren en experts om denkbare en wenselijke toekomstbeelden te genereren. De meeste aandacht gaat uit naar toekomstbeelden op het raakvlak van het waarschijnlijke en het wenselijke.

Het kan een succesfactor zijn als er concurrentie is tussen opdrachtnemers. Dat kan leiden tot concurrentie tussen ontworpen toekomsten. Hierbij doet zich wel het probleem voor dat dit open debat zich slecht verdraagt met de dagelijkse strijd om beleid. Daarin is de reductie van variëteit een manier om eenheid in het beleid te krijgen zodat 'krachtig' beleid gevoerd kan worden.

De opdrachtnemers leren het meeste van de verkenningen en zijn regelmatig teleurgesteld over de benutting van de verkenningen door anderen. Doordat besluitvormers, bestuurders en politici vaak niet deelnemen aan de verkenningstrajecten, lijken zij het minste op te steken van de verzamelde kennis. Na afronding van de verkenningen verdwijnen veel van de verkenners uit de daarop volgende beleidsprocessen.

\section{Het traject van toekomstverkenning}

Verkenningen worden vaak 'gewoon gestart'. In de verkenningstrajecten zijn ook met regelmaat buig- en knikpunten waar te nemen waarop de richting van de verkenning verandert. Soms komen de koerswijzigingen voort uit keuzen van de verkenners, maar met regelmat vinden ook externe interventies plaats, met name uit de beleidswereld. Het belangrijkste dilemma is wel hoe wensbeelden, trends en denkbeelden met elkaar te combineren. Bij ons bestaat het beeld dat met name scenario's waar de drie door elkaar heen gebruikt worden minder bruikbaar zijn voor beleidsprocessen.

\section{De organisatte van de overdracht}

De overdracht van de verkenningen is over het algemeen niet geregeld. Soms worden één of meer rapporten overhandigd en wachten de verkenners verder af. 
Het blijkt moeilijk om de opgedane kennis over te dragen op de organisatie en de opdrachtgever. Meestal nemen of hebben de opdrachtgevers en -nemers daarvoor geen of weinig tijd. We menen te mogen concluderen dat er behoorlijk wat kennis verloren gaat bij de afronding van de verkenning.

\section{Benutting van de resultaten van de toekomstverkenning}

Dat de verkenners leren van hun verkenning is een goede zaak. Als zij vervolgens echter niet behouden blijven voor de organisatie en voor vervolgtrajecten, valt de benutting van kennis tegen. Als de bestuurlijke opdrachtgever sterk betrokken is geweest, en een rol blijft spelen in de vervolgtrajecten, kan een aanzienlijk deel van de kennis worden bewaard, benut en verrijkt. We achten het niet uitgesloten dat verkenningen beter benut worden wanneer ze, sterker dan nu het geval is, gekoppeld worden aan bijbehorende beleidsprojecten. Met name op rijksniveau is dan echter wel een verandering nodig in het denken over het voeren van beleid. 


\section{NOTEN}

1 Verantwoordingsrapport Questa (1998:5). 


\section{INITIATIEFNEMERS EN FINANCIERS}

\section{Commissie Overleg Sectorraden}

In deze commissie vindt overleg plaats tussen vier sectorraden die onder de Raamwet Sectorraden Onderzoek en Ontwikkeling functioneren. Dit zijn de Raad voor Advies voor het Wetenschappelijk Onderzoek in het kader van de Ontwikkelingssamenwerking (RAwOO), de Raad voor Gezondheidsonderzoek (RGO), de Raad voor het Milieu- en Natuuronderzoek (RMNO). Daarnaast neemt deel het NRO en sinds kort ook de Stichting Toekomstbeeld der techniek (STT). In de cos vindt overleg plaats over onderwerpen van gezamenlijk belang. Daarnaast organiseert cosprojecten en conferenties op het terrein van bijvoorbeeld methodiekontwikkeling. Het Coördinatiefonds van de cos financiert dit soort projecten en ook gemeenschappelijke studies van de sectorraden.

\section{Nationale Raad voor Landbouwkundig Onderzoek (NRLO)}

De NRLO is vernieuwd per 1 januari 1995. Haar primaire taak is om sociale, wetenschappelijke en technologische veranderingen te verkennen, die de komende vijftien of twintig jaar de ontwikkelingen kunnen beïnvloeden in de agribusiness, de landelijke gebieden en de visserij. Welke toekomsten kunnen we voorzien en welke mogelijkheden en bedreigingen gaan daar vanuit voor deze sectoren? De verkenningen worden uitgevoerd om strategisch management in landbouwkundig onderzoek te ondersteunen. Hoe kan onderzoek voorbereid zijn op deze toekomstige scenario's, welke strategische keuzen zouden gemaakt moeten worden in het onderzoek zodat rekening gehouden kan worden met de gesignaleerde mogelijkheden en bedreigingen? In bijzonder is het doel van de verkenningen om steun te bieden aan ondernemers, beleidsmakers in landbouwkundig onderzoek, en andere geīnteresseerden in hun pogingen om nieuwe dilemma's, kansen en bedreigingen te verkennen.

\section{Netwerk voor onderzoek en ontwikkeling Ruimtelijk Beleid (Netwerk Ro)}

Het Netwerk is inmiddels opgeheven.

\section{Raad voor het Milieu- en Natuuronderzoek (RMNO)}

De Raad voor het Milieu- en Natuuronderzoek (RMNO) is een sectorraad, ingesteld in 1981. Sectorraden adviseren de Regering over onderzoek op een maatschappelijk aandachtsgebied. De RMNO adviseert over de inhoud en organisatie van onderzoek naar vraagstukken op het gebied van milieu, natuur en landschap die spelen op een termijn van drie tot vijftien jaar.

Behalve een sectorraad voor natuur en milieu, zijn er sectorraden voor gezondheid, landbouw en ontwikkelingssamenwerking.

\section{Wetenschappelifke Raad voor Regeringsbeleid (WRR)}

De Wetenschappelijke Raad voor het Regeringsbeleid is in 1972 op voorlopige basis aan het werk gegaan. In 1976 werd hij definitief bij wet ingesteld. 
De raad houdt zich vooral bezig met ontwikkelingen die op langere termijn de samenleving kunnen beînvloeden. Veel beleidsterreinen zoals bijvoorbeeld gezondheidszorg, verkeer en vervoer, onderwijs vragen om beslissingen die het beeld van de samenleving tientallen jaren lang zullen bepalen. Om zulke beslissingen te kunnen nemen, is een weloverwogen beeld van de toekomst noodzakelijk. De raad probeert nieuwe problemen te verkennen, bestaande problemen in samenhang te bezien en perspectieven en oplossingsrichtingen aan te geven ten behoeve van het regeringsbeleid. Door duidelijk te maken welke onzekerheden een rol kunnen spelen en wat de consequenties zijn van de diverse keuzemogelijkheden probeert de raad een bijdrage te leveren aan de besluitvorming en de kwaliteit ervan. 


\section{D 'TERUGBLIK OP TOEKOMSTVERKENNINGEN' 24 MAART 2000}

\begin{tabular}{|c|c|c|c|c|c|}
\hline \multicolumn{6}{|l|}{ Coreferenten } \\
\hline Mevrouw C. & Grijzen & $\begin{array}{l}\text { Provindehuls Noord } \\
\text { Brabant }\end{array}$ & & 's-Hertogenbosch & Coreferent \\
\hline $\begin{array}{l}\text { Drs. W.M. } \\
\text { Dhr. }\end{array}$ & $\begin{array}{l}\text { De Jong } \\
\text { Den Dunnen }\end{array}$ & $\begin{array}{l}\text { Ministerie van VROM } \\
\text { Ministerie van VROM }\end{array}$ & DGVH/FS\&C & Den Haag & Coreferent \\
\hline De heer $W$. & Lammers & Natuurplanbureau-RIVM & & Bilthoven & Coreferent \\
\hline $\begin{array}{l}\text { Dhr. A.F. } \\
\text { De heer } \mathrm{T} \text {. }\end{array}$ & $\begin{array}{l}\text { V.d. Klundert } \\
\text { Rutjens }\end{array}$ & $\begin{array}{l}\text { Ministerle van LNV } \\
\text { NBM-Amstelland }\end{array}$ & Projectleider & Nierwegein & Coreferent \\
\hline & & & $\begin{array}{l}\text { Woon- } \\
\text { verkenningen }\end{array}$ & & \\
\hline De heer drs. J. & Schuring & $\begin{array}{l}\text { Ministerie van Verkeer } \\
\text { en Waterstaat }\end{array}$ & $\begin{array}{l}\text { Rijks } \\
\text { Luchtvaartdienst }\end{array}$ & Den Hazg & Coreferent \\
\hline $\begin{array}{l}\text { De heer dr. } \\
\text { D.K.J. }\end{array}$ & Tommel & $\begin{array}{l}\text { Directeur Nationaal } \\
\text { Woninginstituut }\end{array}$ & & De BIIt & Coreferent \\
\hline Mevrouw K. & $\begin{array}{l}\text { Van } \\
\text { Herwaarden }\end{array}$ & $\begin{array}{l}\text { Provinciehuis Noord } \\
\text { Brabant }\end{array}$ & & 's-Hertogenbosch & Coreferent \\
\hline De heer ir. L.H. & Keijts & $\begin{array}{l}\text { Ministerie van Verkeer } \\
\text { en Waterstaat }\end{array}$ & $\begin{array}{l}\text { Plv. Directeur- } \\
\text { Generaal } \\
\text { Rijkswaterstaat }\end{array}$ & Den Haag & Coreferent \\
\hline $\begin{array}{l}\text { De heer mr. } \\
\text { L.H.J. }\end{array}$ & Kokhuis & Ministerie van VROM & $\begin{array}{l}\text { Directeur- } \\
\text { generaal }\end{array}$ & Den Haag & Coreferent \\
\hline \multicolumn{6}{|l|}{ Deelnemers } \\
\hline Mevrouw. F. & Alberda & $\begin{array}{l}\text { Instituut voor } \\
\text { Maatschappelljke } \\
\text { Innovatie }\end{array}$ & & Leiden & Deelnemer \\
\hline $\begin{array}{l}\text { Dhr. H. J. M. } \\
\text { Mevr. }\end{array}$ & $\begin{array}{l}\text { Alphen, van } \\
\text { Asselt, van }\end{array}$ & RMNO & & Rjjswijk & Deelnemer \\
\hline De heer J. & Baalen, van & Ministerie van LNV & DWK & Den Haag & Deelnemer \\
\hline $\begin{array}{l}\text { Mevrousw P. } \\
\text { Dhr. }\end{array}$ & $\begin{array}{l}\text { Berkhout } \\
\text { Brouwer }\end{array}$ & $\begin{array}{l}\text { NEI } \\
\text { ABF Onderzoek }\end{array}$ & ARD & Rotterdam & Deednemer \\
\hline Mevrouw M.P. & Bogaerts & $\begin{array}{l}\text { Ministerie van Verkeer } \\
\text { en Waterstaat }\end{array}$ & $\begin{array}{l}\text { Adviesdlenst } \\
\text { Verkeer en } \\
\text { Vervoer }\end{array}$ & Rotterdam & Deelnemer \\
\hline $\begin{array}{l}\text { Mevrouw } \mathrm{T} \text {. } \\
\text { De heer } M \text {. }\end{array}$ & $\begin{array}{l}\text { Booi } \\
\text { Cohen }\end{array}$ & $\begin{array}{l}\text { Laagland Advies } \\
\text { Tu Delft }\end{array}$ & & $\begin{array}{l}\text { Amersfoort } \\
\text { Den Haag }\end{array}$ & $\begin{array}{l}\text { Deelnemer } \\
\text { Deelnemer }\end{array}$ \\
\hline Prof.dr. M.C.E. & $\begin{array}{l}\text { Dam-Mieras, } \\
\text { van }\end{array}$ & WRR & & & Deelnemer \\
\hline Drs. E. & Dammers & Alterra & & Wageningen & Deetnemer \\
\hline $\begin{array}{l}\text { Dr.ir. W. } \\
\text { Ir. O.C.H. }\end{array}$ & $\begin{array}{l}\text { de Haas } \\
\text { de Kuljer }\end{array}$ & $\begin{array}{l}\text { Dienst Landelijk Gebied } \\
\text { KDO Consultancy }\end{array}$ & $\mathrm{I} \& \mathrm{~K}$ & $\begin{array}{l}\text { Utrecht } \\
\text { Amsterdam }\end{array}$ & $\begin{array}{l}\text { Deelnemer } \\
\text { Deelnemer }\end{array}$ \\
\hline De heer ir. N.A. & Dijkveld Stol & NRLO & & Den Haag & Deelnemer \\
\hline De heer A. & Dikmans & $\begin{array}{l}\text { Ministerie van verkeer } \\
\text { en Waterstaat }\end{array}$ & $\begin{array}{l}\text { Projectleider } \\
\text { Questa }\end{array}$ & Den Haag & Deelnemer \\
\hline De heer $L$ & Douw & LE-DLO & $\begin{array}{l}\text { Projectlelder } \\
\text { landbouw en } \\
\text { rulmtegebruik in } \\
\text { Brabant }\end{array}$ & Den Haag & Deelnemer \\
\hline $\begin{array}{l}\text { Mevrouw van } \\
\text { Mevrouw S. van }\end{array}$ & $\begin{array}{l}\text { Donselaar } \\
\text { Eenbergen }\end{array}$ & $\begin{array}{l}\text { Vervangt Dhr. Kraan } \\
\text { Provinciehuis Noord } \\
\text { Brabant }\end{array}$ & & 's-Hertogenbosch & Deelnemer \\
\hline Prof.ir. D.H. & Frieling & $\begin{array}{l}\text { Technische Universiteit } \\
\text { Delft }\end{array}$ & $\begin{array}{l}\text { Dir. Praktijkopt. } \\
\text { Arch.\&Stede } \\
\text { bouwkunde }\end{array}$ & Delft & Deelnemer \\
\hline
\end{tabular}




\begin{tabular}{|c|c|c|c|c|c|}
\hline Drs. W.M.F. & Haarmann & $\begin{array}{l}\text { Telos, } \\
\text { Brabants Centrum voor } \\
\text { Duurzaamheidsvraagstuk }\end{array}$ & & Tilburg & Deelnemer \\
\hline Dr. J.H.A. & Hillebrand & $\begin{array}{l}\text { LandbouwEconomisch } \\
\text { Instituut }\end{array}$ & so & Den Haag & Deelnemer \\
\hline Ir. P. & Hordijk & Provinaie Zuid-Holland & $\begin{array}{l}\text { Bestuursonderste } \\
\text { uning }\end{array}$ & Den Haag & Deelnemer \\
\hline Mw. & Kenter & Nijenrode & & & \\
\hline $\begin{array}{l}\text { De heer J. } \\
\text { Dhr. }\end{array}$ & $\begin{array}{l}\text { Koffijberg } \\
\text { Koopmans }\end{array}$ & $\begin{array}{l}\text { Ministerie van VROM } \\
\text { RMNO }\end{array}$ & DGVH & Den Haag & Deetnemer \\
\hline Dhr. & Kroon & Alterra & & Wageningen & \\
\hline Ir. J.W.M. & Langeveld & & & Chaam & Deelnemer \\
\hline De heer ir. C. & Lever & Ministerie van VROM & DGVH (FS\& C) & Den Haag & Deelnemer \\
\hline Dr. R.J.M. & Maas & RIVM & MNV & Bilthoven & Deelnemer \\
\hline De heer $\mathrm{R}$. & Maessen & $\begin{array}{l}\text { Provincie Noord } \\
\text { Brabant }\end{array}$ & & 's-Hertogenbosch & Deelnemer \\
\hline Prof.dr.ir. G. & Meester & MInisterie van LNV & $\begin{array}{l}\text { Directie } \\
\text { Internationale } \\
\text { Zaken }\end{array}$ & Den Haag & Deelnemer \\
\hline Drs. P. & Morin & $\cos$ & & Zoetermeer & Deelnemer \\
\hline Drs. M.G.G. & Neven & Alterra & & Wageningen & Deelnemer \\
\hline Drs. F. de & Nooij & Provincie Zuid-Holland & $\begin{array}{l}\text { Rulmtelijke } \\
\text { Ontwikkeling }\end{array}$ & Den Haag & Deelnemer \\
\hline Mw. A. & Nijhof & VROM / RPD & & & \\
\hline De heer $\mathrm{H}$. & Oosterveld & RIVM & Natuurplanbureau & Bilthoven & Deednemer \\
\hline Mr. N.R. van & Ravesteyn & VROM & RPD & Den Haag & Deelnemer \\
\hline Dhr. & Roemer & Ministerie oc\&w & & & \\
\hline De heer $\mathrm{H}$. & Sakkers & Gemeente Utrecht & $\begin{array}{l}\text { Strategische } \\
\text { beleid }\end{array}$ & Utrecht & Deelnemer \\
\hline Dhr. & Scheltema & WRR & Voorzitter & Den Haag & Deelnemer \\
\hline De heer drs. $\mathrm{H}$. & Schartman & $\begin{array}{l}\text { Ministerie van Verkeer } \\
\text { en Waterstaat }\end{array}$ & $\begin{array}{l}\text { Directeur } \\
\text { Personenvervoer }\end{array}$ & Den Haag & Deelnemer \\
\hline $\begin{array}{l}\text { De heer } \\
\text { J.G.C.M. }\end{array}$ & Schuyt & Woningcorporatie scw & & Amersfoort & Deelnemer \\
\hline De heer $M$. & Stoffers & Centraal Planbureau & Hoofd Bouw & Den Haag & Deelnemer \\
\hline Drs. J.W. & Straatsma & LTO Nederland & & Den Haag & Deelnemer \\
\hline Ir. J. & Strik & Woonzorg Nederland & & Amsterdam & Deelnemer \\
\hline Drs. J.J.P.M. & Thōnissen & Kolpron Consultants BV & & Rotterdam & Deelnemer \\
\hline Dr. S.P. & Tjallingii & $\begin{array}{l}\text { Alterra Research } \\
\text { Instituut voor de } \\
\text { Groene Ruimte }\end{array}$ & & Wageningen & Deelnemer \\
\hline Dhr. & Tlemersma & & & & \\
\hline De heer A. & Verbaan & $\begin{array}{l}\text { Ministerie van } \\
\text { Volkshuisvesting, VROM }\end{array}$ & RPD & Den Haag & Deelnemer \\
\hline $\begin{array}{l}\text { De heer ir. E.J. } \\
\text { Mevrouw M.M. }\end{array}$ & $\begin{array}{l}\text { Verroen } \\
\text { Versnel- }\end{array}$ & $\begin{array}{l}\text { TNI-INRO } \\
\text { Vereniging }\end{array}$ & Afdelingshoofd & $\begin{array}{l}\text { Delft } \\
\text { 's-Graveland }\end{array}$ & $\begin{array}{l}\text { Deelnemer } \\
\text { Deelnemer }\end{array}$ \\
\hline & Schmitz & Natuurmonumenten & & & \\
\hline Mevrouw H. & Vlug & $\begin{array}{l}\text { Instltuut voor Publiek } \\
\text { en Politiek }\end{array}$ & & Amsterdam & Deelnemer \\
\hline De heer $\mathrm{G}$. & Vos & Ministerie van LNV & $\begin{array}{l}\text { Strategische } \\
\text { Beleidsvorming }\end{array}$ & Den Haag & Deelnemer \\
\hline $\begin{array}{l}\text { Mw. D. } \\
\text { De heer W. }\end{array}$ & $\begin{array}{l}\text { Van der Werf } \\
\text { Wiersinga }\end{array}$ & $\begin{array}{l}\text { VROM / RPD } \\
\text { IKC-Natuurbheer }\end{array}$ & & Wageningen & Deelnemer \\
\hline
\end{tabular}


Gesprekskiders en medewerkers

\begin{tabular}{|c|c|c|c|c|c|}
\hline $\begin{array}{l}\text { Prof.dr.ir. J. } \\
\text { Drs. J.J. } \\
\text { Dr. A.N. }\end{array}$ & $\begin{array}{l}\text { Bouma } \\
\text { Modder } \\
\text { van der Zande }\end{array}$ & $\begin{array}{l}\text { WRR } \\
\text { NIROV } \\
\text { Directeur DLO- } \\
\text { Staringcentrum }\end{array}$ & Netwerk RO & $\begin{array}{l}\text { Den Haag } \\
\text { Den Haag } \\
\text { Wageningen }\end{array}$ & $\begin{array}{l}\text { Gespreksleider } \\
\text { Gespreksleider } \\
\text { Gespreksleider }\end{array}$ \\
\hline Dr. H.C & van Latesteljn & WRR & & Den Haag & Gespreksleider \\
\hline Dr.ir.A.P. & Verkaik & NRLOO & & Den Haag & Gespreksleider \\
\hline Drs. J.B.. & Saris & $\begin{array}{l}\text { De Stad BV/ } \\
\text { projectsecretaris }\end{array}$ & & Amsterdam & Secretariaat \\
\hline $\begin{array}{l}\text { Prof.dr.ing. } \\
\text { G.R. }\end{array}$ & Teisman & EUR/KUN & & & Adviseur \\
\hline Drs. T. & Metze & $\begin{array}{l}\text { De Stad BV/ } \\
\text { projectsecretarlaat }\end{array}$ & & Amsterdam & Secretariaat \\
\hline Mw. S. & Ermers & De Stad BV & & & Verslaglegger \\
\hline Drs. M. & De Winter & De Stad BV & & & Verslaglegger \\
\hline Drs. F. & Den Hertog & De Stad BV & & & Verslaglegger \\
\hline Drs. S. & Ter Woerds & De Stad BV & & & Verslaglegger \\
\hline
\end{tabular}



OUD-MINISTER VAN VROM

Was $u$ wel toe aan toekomstverkenningen op het moment dat gestart werdmet $N \mathrm{~L} 2030$ ? Daar heb ik erg over geaarzeld, ik ben in augustus ' 94 minister geworden en pas zes maanden daarvoor was het beleid van de Vierde Nota extra vastgesteld. Dat was dus jong beleid. Vanuit de kamer was er de wens om een nieuwe Vijfde nota op te starten. Ik wilde nog niet met een nieuwe nota komen maar ik wilde wel nadenken hoe die eruit zou moeten zien. Door altijd te blijven nadenken kan je ook bijsturen.

Maar als je over de toekomst nadenkt dan moet ook over andere toekomsten nagedacht worden dan in het huidige beleid is vastgesteld?

Ik ben er altijd vanuit gegaan dat het onderzoek er zou zijn om bij te sturen. De RPD is een organisatie die pas in de laatste jaren van een planbureau gegroeid is naar een beleidsdienst. Ik ben er als minister vanuit gegaan dat ik met een beleidsdienst te maken had. Maar in die dienst zat als het ware een ingebakken conflict, dat woord is overigens een te groot woord, omdat medewerkers (van een hoog niveau) er vanuit gingen dat de RPD in eerste instantie een planbureau is. Dat lijkt misschien een verschil in woorden maar dat is naar de buitenwereld wel belangrijk.

Als je het hebt over een planbureau dan heb je het over een organisatie die onafhankelijk kan komen met toekomstbeelden en scenario's, los van datgene wat de minister wil. Op het moment dat een RPD, in haar functie als planbureau, met dat soort beelden naar buiten komt, en die beelden zich niet verhouden met het beleid dat de minister op dat moment tracht te bewerkstelligen, dan is dat voor de buitenwereld heel wonderlijk. Die kent namelijk dat subtiele verschil niet dat op het ene ogenblik de RPD functioneert als een planbureau en op het nadere moment als beleidsdienst. Daar zat een wezenlijk onderdeel van een conflict dat we wel eens hebben gehad.

Vindt $u$ dat, doordat het planbureau binnen de beleidsdienst zit, de vrijheid om over de toekomst na te denken wordt beperkt?

Ja, zeker nu ik meer afstand heb genomen van het werk en van de RPD, ben ik nog meer dan voorheen de mening toegedaan dat de RPD haar planbureaufunctie zou moeten uitplaatsen of dat het bij een ander planbureau zou moeten worden ondergebracht. Hoe dat gebeurt, daar heb ik verder geen mening over.

Ik wil met dit verhaal niets afdoen aan de integriteit van de mensen die de scenario's hebben gemaakt. Als dat buiten de deur zou zijn gebeurd, dan had dat door dezelfde mensen gedaan kunnen worden. De verwarring ontstond op het ogenblik dat het allemaal uit de Rijnstraat kwam en het onduidelijk zou worden wat de minister wilde. 
Toen kreeg u drie scenario's voorgeschoteld, daarvan zei u: daar moet een vierde bij, waarom?

Het beleid dat we aan het uitvoeren waren, dat wilden we ook benoemen. We hebben erover nagedacht hoe we dat zouden noemen en dat is stedenland geworden. Ik ben er een voorstander van om het stedelijk gebied te scheiden van het landelijk gebied. Daarom kon het scenario dat op de bestaande situatie was gebaseerd, het stedenland genoemd worden.

Ik heb in de discussies in het land er ook steeds over gezegd: dit zijn de mogelijkheden; daarvan is stedenland gebaseerd op bestaand beleid en u begrijpt van mij dat ik daar een voorstander van ben, maar ik wil graag van $u$ horen wat $u$ ervan vindt. Laten we kijken of in die vijfde nota, of in de nota leefomgeving, uw ideeën geimplementeerd kunnen worden. Of dat we in de nota die geldt tot 2030 tot een ander scenario moeten komen.

Maar, daarmee veranderde u de scenario's van mogelijke naar wenselijke beelden.

$\mathrm{Ja}$, maar ik ben een politicus, ik ben ingehuurd om een bepaald beleid tot stand te brengen en te bewerkstelligen. In de lijn van het kabinet maar ook in de lijn van mijn eigen partij is er een continuïteit geweest van de versterking van stad en land in afzonderlijkheid. Dat heb ik ook volgehouden maar als daar dwars doorheen een verhaal zou komen van mij, dat het ook palet of iets anders zou kunnen zijn, dan is dat eigenaardig voor mensen. Wat hebben zij aan een minister waarmee zij convenanten afsluiten en die tegelijkertijd iets anders mogelijk acht.

Bij de discussie over de toekomst van de ruimtelijke ontwikkeling heb je ook een voorkeur gehad omdat breder te doen, vindt $u$ dat het nog een keer geprobeerd zou moeten worden?

Absoluut, ik heb later nogal wat artikelen gelezen die in de zeventiger en tachtiger jaren zijn geschreven over planvorming, ook in die periodes zijn er pogingen gedaan om tot een integratie van ruimtelijke plannen op nationaal niveau te komen. Je kunt zien dat er altijd een soort stille strijd is geweest om de ruimtelijk macht, om het zo maar te noemen, in Nederland: tussen v\&w, landbouw en de RPD en later ook DGM.

Ik heb in eerste instantie getracht te komen tot een integratie van milieubeleid en ruimtelijke ordeningsbeleid omdat die twee heel veel met elkaar te maken hebben. Heel veel milieuproblemen werden opgelost door er een ruimtelijke contour omheen te leggen of door het te isoleren, dat betekent dat je eigenlijk op een onzorgvuldige manier bezig bent met ruimtebeslag. Dat koste binnen VROM moeite maar dat hebben we wel voor elkaar gekregen en er was enthousiasme. Van buitenaf ontstond de roep om het water en groen er ook bij te doen. Dat heb ik geprobeerd tegen te houden omdat we eerst de eerste tranche moesten afronden. Uiteindelijk heeft het plan het niet gehaald in het kabinet en tussen de collega ministers. Dat was jammer, het was ook aan het einde van de kabinetsperiode en dan voelt een kabinet er niet veel voor om vergezichten naar buiten te brengen, dat is allemaal afbreukrisico. 
Als de RPD misschien herplaatst zou worden, kan dan de integraliteit bevorderd worden door het te plaatsen bij een gemeenschappelijk planbureau voor de omgeving, zou dat bevorderlijk zijn?

Het lijkt me een aantrekkelijke gedachte, maar als je er langer over nadenkt dan zitten er vast meer voor- en nadelen aan, het RrvM heeft natuurlijk ook nog andere takken van sport. Misschien kunnen alle ruimtelijke taken eruit gehaald worden, het RIVM kan zich bijvoorbeeld dan alleen met de volksgezondheid bezig zou houden. Ik heb daar geen uitgesproken mening over. Maar de bundeling van sociale wetenschappen en ruimtelijke onderzoeken in een planbureau lijkt mij een goed idee.

Het laatste punt: in een advies van de wRR over ruimtelijke ontwikkeling wordt gezegd dat we niet meer zo zouden moeten werken met generieke ruimtelijke concepten, beperk je maar wat, de overheid kan het toch allemaal niet sturen, is dat ook uw opvatting?

Nee, de overheid kan sturen en dient ook meer te sturen dan zij soms doet. Sterker nog, mensen, burgers, vragen daar ook om. Ik denk dat een van de problemen waar wij mee te maken hebben gehad, was niet dat we geen aardig beleid hadden maar dat we ons daar niet aan hielden dat werkt door naar Provincies en gemeenten.

Als je naar het tempo kijkt, de tijd tussen de ruimtelijke nota's dan blijkt dat we sneller ingehaald worden door de dynamiek van de samenleving. Dan komt er een vijfde nota, wordt die dan niet al ingehaald?

$\mathrm{Ja}$, zonder meer, maar je kan zeggen dat er grote strategische nota's zijn en dat ten aanzien van onderdelen, we met uitvoeringsnota's komen per deelonderwerp of per geografische eenheid.

Je kunt natuurlijk met slimme oplossingen komen om met die dynamiek rekening te houden. Ook in een plankaart kan toch vastgelegd worden dat we de steden intact houden en de grote cultuurhistorische waarde van het natuurhistorisch gebied, van agrarische ontwikkelingen, ook bij geografische eenheid kan dat vastgelegd worden. Dat betekent niet dat er geen discussies gevoerd kunnen worden over die grenzen maar dan ben je er wel van bewust dat het kwetsbaar gebied is en daar alleen van afgeweken kan worden als daar een grote maatschappelijke noodzaak voor is.

Nu zijn we iets te gemakkelijk met het afwijken. 